2015

THE FANNED FLAMES OF DISCONTENT: A SOLIDARITY-INSPIRED HISTORY OF THE IDENTITY/IDEOLOGY, CULTURAL HISTORY, AND RHETORICAL STRATEGIES OF THE WOBBLIES DURING THE 1916 MINNESOTA IRON ORE STRIKE

Gary Kaunonen

Michigan Technological University

Follow this and additional works at: https://digitalcommons.mtu.edu/etds

Part of the American Studies Commons, History Commons, and the Rhetoric Commons Copyright 2015 Gary Kaunonen

Recommended Citation

Kaunonen, Gary, "THE FANNED FLAMES OF DISCONTENT: A SOLIDARITY-INSPIRED HISTORY OF THE IDENTITY/IDEOLOGY, CULTURAL HISTORY, AND RHETORICAL STRATEGIES OF THE WOBBLIES DURING THE 1916 MINNESOTA IRON ORE STRIKE", Dissertation, Michigan Technological University, 2015.

https://doi.org/10.37099/mtu.dc.etds/944

Follow this and additional works at: https://digitalcommons.mtu.edu/etds

Part of the American Studies Commons, History Commons, and the Rhetoric Commons 


\title{
THE FANNED FLAMES OF DISCONTENT: A SOLIDARITY-INSPIRED HISTORY OF THE IDENTITY/IDEOLOGY, CULTURAL HISTORY, AND RHETORICAL STRATEGIES OF THE WOBBLIES DURING THE 1916 MINNESOTA IRON ORE STRIKE
}

\section{By}

Gary Kaunonen

\begin{abstract}
A DISSERTATION
Submitted in partial fulfillment of the requirements for the degree of DOCTOR OF PHILOSOPHY

In Rhetoric, Theory and Culture
\end{abstract}

MICHIGAN TECHNOLOGICAL UNIVERSITY

2015

(C) 2015 Gary Kaunonen 
This dissertation has been approved in partial fulfillment of the requirements for the Degree of DOCTOR OF PHILOSOPHY in Rhetoric, Theory and Culture.

Department of Humanities

Dissertation Advisor: Dr. Robert Johnson

Committee Member: $\quad$ Dr. Elizabeth Flynn

Committee Member: Dr. Carol MacLennan

Committee Member: $\quad$ Dr. Fredric L. Quivik

Department Chair: $\quad$ Dr. Ronald Strickland 


\section{Table of Contents}

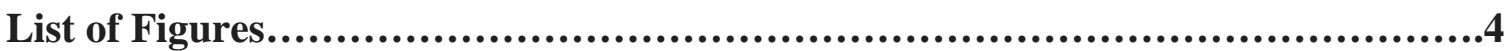

List of Tables..............................................................................

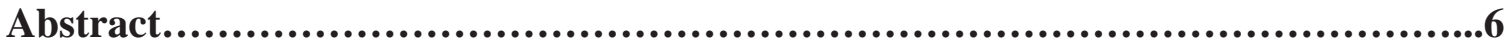

Introduction and Overview

Solidarity-inspired History-Framework and Practice $\ldots \ldots \ldots \ldots \ldots \ldots \ldots \ldots \ldots \ldots$

Section: Landscape, Community, and Labor

Solidarity-inspired History Vignette and Section Introduction..................42

Chapter 1: A Tinder-dry Landscape........................................51

Chapter 2: Labor, Strikes, and Progressives................................. 79

Section: Identity and Ideology

Solidarity-inspired History Vignette and Section Introduction.................115

Chapter 3: Collecting Kindling-Radical Education and Literacy in Identity

Formation......................................................... 125

Chapter 4: Stoking the Ideological Fires-Sabotage, Organized Labor,

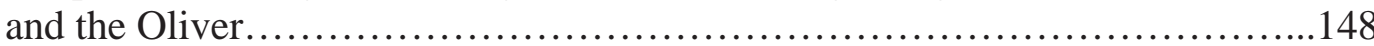

Section: Cultural History and Material Culture

Solidarity-inspired History Vignette and Section Introduction................. 168

Chapter 5: Fire Starters - the IWW as Cultural Actors.........................177

Chapter 6: Social Spaces and Melodic Voices of Fiery Discontent.............. 196

Section: Rhetorical Studies and Labor History

Solidarity-inspired History Vignette and Section Introduction................216

Chapter 7: Fiery Rhetoric on the Ranges................................228

Chapter 8: Minnesota's Governor Fires Back................................266

Chapter 9: A Flame Extinguished ..................................... 310

Conclusion

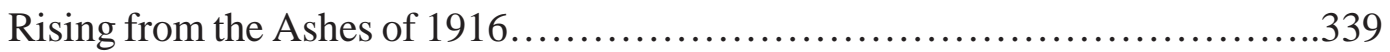

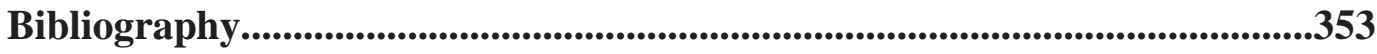




\section{List of Figures}

Figure 1.1 Map of Northern Minnesota showing the three Iron Ranges......................52

Figure 1.2 Map of Vermilion Iron Range showing principle urban areas and mines, ca.

1910

Figure 1.3 Map of Itasca and St. Louis County Urban Centers, ca. 1910....................54

Figure 1.4 Contemporary image of the Hull-Rust-Mahoning Pit in Hibbing...............55

Figure 1.5 Map of the North and South Ranges of the Cuyuna Iron Range..................56

Figure 4.1 Most common representation of Sabo Tabby in IWW literature...............156

Figure 5.1 Image of Father Hagerty's original Wheel, ca. 1905.............................182

Figure 5.2 Stylized version of Father Hagerty's Wheel, ca. 1920...........................184

Figure 5.3 "Under the Stars and Stripes on the Mesabi" political cartoon..................190

Figure 6.1 Exterior view of the Socialist Opera House, Virginia, Minnesota............206

Figure 6.2 Interior photo of the Socialist Opera House ........................................206

Figure 6.3 Exterior view of the Hibbing Workers Hall, Hibbing, Minnesota.............209

Figure 6.4 Interior photo of the Hibbing Workers Hall stage and scenery................209

Figure 6.5 Interior photo of the Hibbing Workers Hall seating and balcony..............210

Figure 6.6 Copy of the "Joe Hill Memorial Edition" of the Little Red Songbook.......211

Figure 7.1 Images of the IWW produced in Guide to Industrial Unionism..........234

Figure 7.2 IWW parade through the streets of a Mesabi Range town................237

Figure 7.3 Strikers' News masthead and IWW logo...........................239

Figure 7.4 IWW cartoon produced during the 1916 Strike.......................254

Figure 7.5 IWW members outside of the Virginia Socialist Opera House...........257

Figure 7.6 Finnish language IWW songbook.................................259 
Figure 8.1 Sosialisti account of the "Murder" of John Alar........................280

Figure 8.2 Ahjo, No. 6, 1916, "Carlo Tresca bringing money to Alar's wife".........281

Figure 8.3 John Alar's funeral through the streets of Virginia, Minnesota...........283

Figure 8.4 Image from the International Socialist Review.......................283

Figure 8.5 The inhabitants of the Mosonovich boarding house....................300

Figure 9.1 Cartoon from the "kept press"

Figure Conclusion 1 Certificate of contribution to the IWW's 166 trial defense........340

Figure Conclusion 2 Contemporary image of USW Local 1938 mural.................346

Figure Conclusion 3 Contemporary image of the former Socialist Opera House.........348

\section{List of Tables}

Table 2.1 Major Ethnicities Employed by the OIMC after the 1907 Mesabi Range

Strike.............................................................................106-107 


\section{$\underline{\text { Abstract }}$}

Rooted in critical scholarship this dissertation is an interdisciplinary study, which contends that having a history is a basic human right. Advocating a newly conceived and termed, Solidarity-inspired History framework/practice perspective, the dissertation argues for and then delivers a restorative voice to working-class historical actors during the 1916 Minnesota Iron Ore Strike. Utilizing an interdisciplinary methodological framework the dissertation combines research methods from the Humanities and the Social Sciences to form a working-class history that is a corrective to standardized studies of labor in the late 19th and early 20th centuries. Oftentimes class interests and power relationships determine the dominant perspectives or voices established in history and disregard people and organizations that run counter to, or in the face of, customary or traditional American themes of patriotism, the Protestant work ethic, adherence to capitalist dogma, or United States exceptionalism. This dissertation counteracts these traditional narratives with a unique, perhaps even revolutionary, examination of the 1916 Minnesota Iron Ore Strike. The intention of this dissertation's critical perspective is to poke, prod, and prompt academics, historians, and the general public to rethink, and then think again, about the place of those who have been dislocated from or altogether forgotten, misplaced, or underrepresented in the historical record.

Thus, the purpose of the dissertation is to give voice to historical actors in the dismembered past. Historical actors who have run counter to traditional American narratives often have their body of "evidence" disjointed or completely dislocated from the story of our nation. This type of disremembering creates an artificial recollection of 
our collective past, which de-articulates past struggles from contemporary groups seeking solidarity and social justice in the present. Class-conscious actors, immigrants, women, the GLBTQ community, and people of color have the right to be remembered on their own terms using primary sources and resources they produced. Therefore, similar to the Wobblies industrial union and its rank-and-file, this dissertation seeks to fan the flames of discontented historical memory by offering a working-class perspective of the 1916 Strike that seeks to interpret the actions, events, people, and places of the strike anew, thus restoring the voices of these marginalized historical actors. 


\section{Introduction and Overview: Solidarity-inspired History-Framework and Practice}

On June 3, 1916, forty mineworkers from the St. James Mine in Aurora, Minnesota, walked off the job. Their grievances-corruption in the contract mining system, low wages, and dangerous working conditions - resonated strongly with the multi-ethnic workforce across northern Minnesota's Iron Ranges, which was composed of the Mesabi, Vermilion, and Cuyuna Ranges. The revolt spread rapidly, and in a few short weeks some ten to fifteen thousand mineworkers on the Iron Range were on strike against one of the most powerful, and wealthiest, corporations in the United States—-the Oliver Iron Mining Company (OIMC or the Oliver), a subsidiary of the United States Steel Corporation-as well as a number of independent mining operations.

The strikers' grievances were the standard complaints of many industrial workers who had previously commenced labor actions in the United States. More uncommon was the revolutionary industrial union the immigrant mineworkers chose to represent them in this contentious clash between labor and management. The Industrial Workers of the World (IWW) rushed to the Minnesota Iron Ranges chasing the industrial conflict in an attempt to rapidly organize the immigrant workers during the strike. Agitating, organizing, and unifying the Ranges' multi-cultural workforce in this David versus Goliath industrial battle was the anarchist-branded, somewhat infamous revolutionary industrial union known as "The Wobblies" to their members, and the "I.W.W.s" or "I Won't Works" to the Oliver and their industrial cohorts. The OIMC's sense of absolute control on the Minnesota Iron Ranges was all the more notable given the extreme repression meted out by company guards, police, and vigilantes before, during, and after the strike. Although the strike was widely considered to be a defeat, when the dust had 
settled in September 1916, the workers returned to the mines with the promise of a ten percent pay increase and an eight-hour workday. The 1916 Strike was a testament to the developing class-consciousness of exploited immigrants, many of whom had been in the United States less than a decade, working in and around the open pits and hard rock shafts of Minnesota's Iron Ranges.

Minnesota's Iron Ore Strike of 1916 was the third, and last, of three major industrial disputes in the Upper Midwest's mining industry during the first two decades of the twentieth-century. Unlike the 1907 Mesabi Iron Range Strike in Minnesota and the 1913-1914 Michigan Copper Strike in that state's Upper Peninsula_-both led by the Western Federation of Miners (WFM) — the 1916 strike was organized by the Wobblies, and can best be understood as a radical extension of the WFM's previous organizing efforts. The 1916 Minnesota Iron Ore Strike helped to lay the foundation for a sturdy IWW presence and labor radicalism in northern Minnesota and surrounding environs, especially amongst the region's Finnish immigrant workers.

In addition to mining company managers, the immigrant solidarity fostered before and during the 1916 Strike angered many in Minnesota. Craft and trades unions such as those in the American Federation of Labor (AFL) balked at the IWW's efforts to extend union membership to immigrant radicals and offered little help to such workers. Progressive politicians such as Hibbing, Minnesota's Mayor Victor L. Power saw the IWW as a nuisance, and attempted to steer striking workers toward affiliation with the AFL. As the strike raged on the Ranges, a citizen's committee with support from the mining companies was set to deport the strike leaders from the Iron Range. To the chagrin of mining company managers this vigilante-style organization of middle-class 
businessmen lost their gumption, but at the prodding of the mining companies Minnesota's Governor, Joseph A. A. Burnquist, contributed to a nefarious plot to deport the IWW's leaders from the Iron Ranges. After issuing a "Law and Order" proclamation, striking workers were engaged by mining company thugs in an ill-fated exchange of gun fire just three days after the Governor's proclamation. In the melee, two people died and others were severely wounded. While it seemed that the strikers were attempting to defend themselves during the fracas, they were charged with first degree murder. Astonishingly, so were IWW organizers who were more than thirty-miles away from the location of the deadly confrontation. The IWW organizers, along with the striking workers involved in the shootings, were arrested and deported from the Ranges via train to the county jail some sixty miles away in Duluth, Minnesota. Through the research of primary documents Minnesota's highest elected official can be linked to helping orchestrate the devious plot to deport the IWW organizers, which helped mining companies turn the tide of the labor confrontation and eventually break the strike. Underlying most of the anti-IWW action on the Ranges was a less than subtle anti-immigrant attitude. Immigrants from Finland, southeastern Europe, and Italy were good enough to work and die in the mines, but not human enough to have a voice in the conditions of their labor. Bordering on outright racism that would make eugenicist Francis Galton blush, mining company management, public officials, and local business people chided the prospects of an industrial union that gave immigrant workers and their families a voice of their own on the Iron Ranges. Immigrants were also being accused of un-American sentiment as the paranoia of World War I raging in Europe exacerbated 
fears and rumors that the IWW was being funded in part by the Kaiser's German and Emperor's Austrian governments.

Less than a year after the strike's conclusion, Minnesota became the second state to pass criminal syndicalist legislation, and in September 1917, the first state to convict someone under this law. As historian John E. Haynes argued, "techniques used to suppress the IWW in northern Minnesota were later extended to pacifists, war dissenters, and members of the Nonpartisan League who faced official persecution for their beliefs and activities."1 Criminal syndicalist legislation, which outlawed actions and groups espousing revolutionary methods of economic, political, or social change, was just one volley in the repressive barrage of World War I era persecution. Anti-sedition, antiimmigrant, and anti-labor legislation at the state and federal levels stripped citizens and immigrants alike of fundamental human rights, along with civil liberties specified in the Bill of Rights.

In this manner, the 1916 Strike's legacy was not only of regional significance, but of national importance as the exacting legislation used to discipline labor on Minnesota's Iron Range laid the foundations for authoritarian actions and legislation used in the repressive World War I years and the subsequent Red Scare era. With this sense of national, regional, and local significance in mind, the aim of this dissertation is to provide a unique, interdisciplinary working-class history of the 1916 Strike that presents and preserves the perspective and voices of the workers and families who lived the strike.

\footnotetext{
${ }^{1}$ John E. Haynes, "Revolt of the 'Timber Beasts': IWW Lumber Strike in Minnesota” in Anne J. Aby (ed.), The North Star State: A Minnesota History Reader (St. Paul: Minnesota Historical Society Press, 2002), 299.
} 


\section{History as a Human Right}

In this dissertation, the struggle to represent the voices of the Iron Range's past social actors is an attempt to restore agency to posthumous members of Minnesota's working-class. This voice, individual and collective, should be seen as nothing less than a human right. The denial of such an inalienable right is a common way for autocrats, oligarchs, and oppressive governments to censor the past and squelch future dissent. Perhaps the best example of editing the past to change the historical record comes from George Orwell's classic dystopian novel 1984. Written in 1949, 1984 draws upon the offences of Stalin's repressive Soviet Union in attempting to control, manipulate, and rewrite history. The book's protagonist, Winston Smith, is tasked with purging primary sources of names and events in a propaganda effort to make Big Brother and the ruling Inner Party a quasi-divine entity free from a tarnished past. Winston sat at his desk day in, day out, editing and revising the content of newspapers and photographs in an attempt to make history correlate to the ruling oligarchy's version of the past. In the process, Winston and his colleagues were creating an entire population of "unpersons" who were not merely erased from the primary sources, but rather had their entire history expunged from public memory. ${ }^{2}$

Being a part of the historical record and public memory should be seen as a basic human right, similar to other universal human rights guaranteed by the United Nations. Yet, while the United Nations has a "History" of its thirty article "Universal Declaration of Human Rights," it does not include having a history as one of those universal human

\footnotetext{
${ }^{2}$ George Orwell, 1984, New York: Signet Classic, 1950.
} 
rights. Similarly, in his eloquent and moving Nobel Prize acceptance speech in 2014, Kailash Satyarthi recalled his own personal history as he matured from small boy to champion of human rights, "As a child, I had a vision of tomorrow. That cobbler boy [who I once was] was studying with me in my classroom. Now, that tomorrow has become TODAY. I am TODAY, and you are TODAY." As Satyarthi commented on the immediate nature of establishing human rights for present-day children he brought his speech to a crescendo by emphatically stating, "TODAY it is time for every child to have the right to life, the right to freedom, the right to health, the right to education, the right to safety, the right to dignity, the right to equality, and the right to peace." 3 While Satyarthi's expressive dialogue emphatically compels people to consider the basic human rights of contemporary children it forgets that the establishment of these basic rights, the chronicle of the struggles to attain such rights, and the past abuses of such rights are preserved in a historical record that is often denied existence by those seeking to dislocate the past from present social actors.

Therefore, in addition to the United Nations' and Satyarthi's fundamental identifications of the aforementioned human rights, having a history should take its place among the basic, fundamental, and universal rights of human beings. Having a history bestows a sense of dignity, identity, place, and unity among individuals and groups and these qualities provide an essential understanding of what it means to be human and a

\footnotetext{
${ }^{3}$ United Nations, “The Universal Declaration of Human Rights," in Human Rights, accessed at http://www.un.org/en/rights/, on December 12, 2014, and Kailash Satyarthi, "Nobel Prize Award Acceptance Lecture,” December 10, 2014, Stockholm, Sweden, accessed at http://www.nobelprize.org/nobel_prizes/peace/laureates/2014/satyarthi-lecture_en.html, on December 12, 2014.
} 
part of humanity. The censorship or silencing of history is no less detrimental than the withholding of dignity, education, equality, justice, or liberty. It could even be argued that having a history and knowing one's place in history is a fundamental component in establishing and identifying many of the United Nation's thirty articles of universal human rights. In this manner, it could be further argued that history is the progenitor of all basic and universal human rights.

Thus, the central perspective, or main argument, of this dissertation is that having a history is a basic human right and the subsequent chapters are an assertion of this right for striking immigrant workers on the Minnesota Iron Ranges. Oftentimes multiple perspectives on the same event, experience, or person, can form a mosaic of understanding that generates a seemingly comprehensive depiction of the entirety of a historical experience. More often, though, class interests, hierarchical rigidity, and power relationships determine the dominant perspectives established in history and disregard perspectives and voices that run counter to, or in the face of, customary or traditional "American" themes of patriotism, the Protestant work ethic, adherence to capitalist dogma, or United States exceptionalism. This dissertation is meant to counteract these traditional narratives with a unique look at the 1916 Minnesota Iron Ore Strike. This dissertation's title, taken from the Wobbly's popular Little Red Songbook, which held a cherished collection of "Songs to Fan the Flames of Discontent," and purpose is to poke, prod, and prompt academics, historians, and the general public to rethink, and then think again, about the place of those who have been dislocated from or altogether forgotten, misplaced, silenced, or underrepresented in the historical record. 
As an assertion of such a basic human right as having a history, in many ways this dissertation is an attempt to give voice to the dismembered past. Historical actors who have run counter to traditional American narratives often have their body of "evidence" disjointed or completely dislocated from the story of our nation. This type of disremembering creates an artificial recollection of our collective past, which dearticulates past class struggles from contemporary groups seeking social justice in the present. Class-conscious historical actors, immigrants, women, the GLBTQ community, and people of color have the right to be remembered on their own terms using historical sources and resources they produced. Therefore, similar to the IWW and its rank-and-file, this dissertation seeks to fan the flames of discontented historical memory by offering a working-class perspective of the 1916 Strike that seeks to interpret the actions, events, people, and places of the strike in new ways. This dissertation is a statement of a fundamental human right—having a history_-and the research, writing, and methodological means toward this end are a unique critical perspective developed specifically with this goal in mind.

\section{Solidarity-inspired History: A Critical Perspective}

This dissertation presents a type of critical history that embraces the use of primary, temporally appropriate sources to speak for underrepresented historical actors, while at the same time seeking to engage current and future actors in on-going struggles of the past. Such a narrative form and methodological practice is here termed Solidarityinspired History $(\mathrm{SiH})$. As a framework/practice perspective, this dissertation has two components: first, the dissertation has sought to establish that history is a human right, and secondly, demonstrating how such a critical perspective can be crafted in a scholarly 
work. In short, this dissertation intends to show the power of its history as a human rights perspective through practice: its scholarship.

Building on the work of past critical perspectives, which are discussed in detail later in this "Introduction and Overview," an operational definition of what critical history should entail in the context of $\mathrm{SiH}$ is necessary, and follows. Beginning from the perspective that having a history should be considered a basic human right, critical historians should work to develop posthumous agency and voice for those who have been marginalized or purposefully left out of the historical record. In many ways, then, critical history is a question of what composition pedagogues might term "voice." SiH provides a restorative voice to those mis-or underrepresented by utilizing non-standard, oftentimes overlooked sources such as oral history, oral tradition, material culture studies, and second-language sources. Seeking to find a voice for those who have been silenced in the historical record, critical historians should cultivate a body of scholarship that: 1) establishes or reasserts agency to historical actors through methodologically appropriate sourcing of unconventional, overlooked, or underutilized materials; 2) critiques institutional or scholarly tradition or commonly held hierarchies, while advocating progressive economic, cultural, political, professional, or social change; and 3) advances an understanding of the plight of previously unempowered historical actors to provide context for contemporary issues of social justice.

In the restoration of voice, $\mathrm{SiH}$ is attempting to make the historical struggles of the past relevant to contemporary cultural, economic, political, and social circumstances by linking historical actors with current social movements. In this dissertation, such a connection will be provided by short vignettes at the beginning of each section, which 
link a contemporary circumstance, event, or social actor(s) with a historical experience from the 1916 Minnesota Iron Ore Strike. The intended outcome is to make history relevant to contemporary cultural, economic, political, or social actors.

This dissertation's advocacy for industrial democracy and social justice can be directly linked to, and was motivated by a classic Wobbly song titled "Solidarity Forever." This powerful organized labor hymn espouses the spanning of time to create a lasting unity among toilers, regardless of job or chronological circumstance. Penned in 1915 by Ralph Chaplin, one of the IWW's most prolific song writers, "Solidarity Forever" rouses feelings of collective action through its social and temporal linkages between an eternally exploited working-class. The evocative tune first joined other Wobbly songs in 1916's Little Red Songbook, but quickly became a favorite in union halls across the United States. Two verses and the song's chorus sum up the perspective of $\mathrm{SiH}$ particularly well:

It is we who plowed the prairies, build the cities where they trade

Dug the mines and build the workshops, endless miles of railroad laid

Now we stand outcast and starving 'mid the wonders we have made but

The union makes us strong.

Solidarity Forever

Solidarity Forever

Solidarity Forever

For the union makes us strong 
In our hands is placed a power greater than their hoarded gold

Greater than the might of armies magnified a thousand-fold

We can bring to birth a new world from the ashes of the old

For the union makes us strong. ${ }^{4}$

A key factor in the research and writing of $\mathrm{SiH}$ is first interrogating the prior agency afforded historical actors through historiography. SiH should then examine such claims of agency and determine whether it has been effectively asserted, needs to be reasserted, or perhaps even crafted anew in a discussion of the past. Additionally, this socially engaged historical practice should also examine whether this agency is appropriately conveyed; is a narrative accurate, and if it is not, critical history should seek to redress this shortcoming. While such a process could be described as re-interpreting history, $\mathrm{SiH}$ does not, however, make-up history to serve a means to an end and recognizes that history can never be discretely "factual" because of the subjective nature of empirical data collection that was generated by humans. Rather, $\mathrm{SiH}$ reinterprets and redresses past historical writing and then takes further steps to ensure an accurate portrayal of historical actors, movements, and organizations that have been marginalized or spurned by traditional historical scholarship. Finally, $\mathrm{SiH}$ creates a narrative of the past that is generated by primary sources produced by marginalized actors and groups with the intention of informing, engaging, and ultimately activating future social actors. In short, $\mathrm{SiH}$ offers historical actors contemporary comrades.

\footnotetext{
${ }^{4}$ Ralph Chaplin, "Solidarity Forever," in I.W.W. Songs to Fan the Flames of Discontent, Joe Hill Memorial Edition, Cleveland, Ohio: I.W.W. Publishing Bureau, n.d. and Industrial Workers of the World, "Solidarity Forever," in IWW Cultural Icons, accessed at http://www.iww.org/history/icons/solidarity_forever, May 1, 2014.
} 
Striking workers on Minnesota's Iron Ranges were not, in most cases, afforded the basic human right of having their own history or the opportunity to posthumously be engaged with contemporary social actors because their plight and politics fell on the wrong side of celebratory, traditional narratives in American history. This dissertation offers, proposes, and suggests that today's activists, social justice advocates, and union members embrace the opportunity to become engaged with and learn from the historical actors of this pivotal time in our nation's history by seeking to understand, reinterpret, and redefine the parameters of traditional historical scholarship and join in the continuous fight for social justice anew. As conceived in this dissertation, $\mathrm{SiH}$ is a critical historical perspective that borrows from a long interdisciplinary lineage of socially engaged and informed scholarship.

\section{A Literature Review of Critical Perspectives in History}

Critical perspectives in history have a long arc in the study of the past. Just as we are struggling with cultural, economic, and social justice questions today, previous critical perspectives and their theorists have also struggled with these questions. Perhaps first to articulate such a critical perspective based on inequality using historical methodology, and thus a primary example of a critical history, was Karl Marx. His $A$ Contribution to the Critique of Political Economy discusses how modes of production are related between classes and how unequal distribution of wealth, created by the evolution of industrial technology, led to an era ripe for social revolution. Marx's historicism, his empirical study of past actors and the effect that technology had in creating, manipulating, and ultimately enslaving a nascent working-class, was indeed a critical 
perspective that sought to give voice to the industrial proletariat. ${ }^{5}$ The works of Marx and other critical scholars who have carried his historical torch provide a necessary corrective to the past that provides the opportunity for social justice, positive action, and progressive change because as Marx astutely pointed out in his Theses on Feuerbach, "Philosophers [perhaps more so historians] have interpreted the world in various ways; the point is to change it." 6

With Marx's founding work on establishing a critical interpretation of history, $\mathrm{SiH}$ is then perhaps a logical extension of British Marxist historian E.P. Thompson's pioneering project to chronicle the lived experience of historical actors from the "bottomup," by propelling the lived experience of historical actors into the future in an effort to form solidarity across the great temporal divide.

Thompson's work was highly influential, and made its way across the Atlantic Ocean in albeit a transformed manner. Perhaps America's most well-known critical historian is Howard Zinn. It was Zinn, son of the social upheavals of the 1960s progressive social movements, who wrote the classic critical history of United States counterculture. Zinn's controversial undertaking was to write a sweeping and unconventional history of the United States, and he does this in his canonical work, $A$ People's History of the United States: 1492 to Present. A People's History chronicles the story of women, the disenfranchised, minorities, those in poverty, and anti-war activists, and has become a monumental work in both scope and significance. Methodologically,

\footnotetext{
${ }^{5}$ Marx, A Contribution to the Critique of Political Economy, at Marxists.org, http://www.marxists.org/archive/marx/works/1859/critique-pol-economy/, accessed March 16, 2014. ${ }^{6}$ Marx, Theses on Feuerbach, at Marx-Engels Internet Archive, http://www.marxists.org/archive/marx/works/1845/theses/theses.htm, accessed March 16, 2014.
} 
Zinn employs huge tracts of block quotations, unconventional sources such as oral history, folklore, and oral tradition, to provide the opportunity for historical actors to “speak" for themselves. This methodology reflects Zinn's alternative approach to "doing” history as he attempts to restore agency posthumously to those who never had it during their lives. The use of unconventional sources and primary voices differentiates Zinn's critical history from that of traditional histories (even customary labor histories) that employ a more standardized framework of scholarly analysis of documents alone. Zinn prefers to let the people speak for themselves.

Another example of how A People's History differs from conventional histories of the United States is captured in Zinn's refutation of a homogenous construction of social history espoused by reactionary authors. Critical of conservative ideologues such as Nixon crony Henry Kissinger, Zinn disputed Kissinger's assertion that "history is a memory of states." Zinn countered with binaries, "the history of any country, presented as a history of a family, conceals fierce conflicts of interests between conquerors and conquered, masters and slaves, capitalists and workers..."7 Traditional historians chronicle the past; Zinn filtered lived historical experience to inform the present and change the future.

Perhaps the first American labor historian to adopt E.P. Thompson's framework of lived experience and write from a "history from below" perspective was Herbert Gutman. Writing in the late 1960s and early 1970s, Gutman innovated methodologically with the insertion of culture as a part of lived experience in the lives of the American working-

\footnotetext{
${ }^{7}$ Howard Zinn, A People's History of the United States: 1492 to Present, (New York: Harper Perennial Modern Classics, 2005), 9.
} 
class. Gutman's work provided an opportunity for others to develop further and extend the field of critical historical inquiry to ethnic, racial, community, and feminist studies of the proletarian past. Alice Kessler-Harris, whose own research and writing was greatly influenced by Gutman's work, further asserted the importance of what became known as the New Labor History by writing that "cultural identity acts as a force of its own to influence workers' behavior and their work choices." ${ }^{8}$ Kessler-Harris' work is steeped in this type of reassessment of historical actors, and extends the reach of a critical perspective to one of the most alienated historical actors: working-class women. Her publications on the plight of women workers stands out as a testament to the power of unconventional historical examinations of disempowered actors. As a rather sweeping chronicle of women wageworkers from colonial times to the advent of advanced capitalism, her book Out to Work: A History of Wage-earning Women in the United States, highlights the lived experiences of women as they enter, are dismissed, or become marginalized during rapid changes to the American workplace.

Perhaps most prescient is Kessler-Harris' study of the dual nature of women's roles as wage earner and family member/care provider. Especially during the advent of the industrial revolution, the roles of women began to change in drastic and unimaginable ways. Industrial work, the mechanization of labor, and the loss of traditional forms of production, provided women with new opportunities that were not always in correlation with social norms and then-contemporary standards of gendered constructs for spheres of labor. Industrial capitalism changed the relations of production both on the shop floor and

\footnotetext{
${ }^{8}$ Alice Kessler-Harris, Out to Work: A History of Wage-earning Women in the United States, (New York: Oxford University Press, 1982), 323.
} 
at home. Of course, this conundrum was not within the purview of actual wageworkers, but rather a debate that would shape the discourse on wage-earning women in the class that employed such women workers. As Kessler-Harris contemplates in Out to Work, "was it possible for women to work at the exploitative jobs available to them and still fulfill family responsibilities...could the social expectations that placed women at a disadvantaged position in the labor market be adjusted so that women could better protect themselves? Either way, the middle class saw wage work for poor women as an issue to be dealt with in terms of responsibilities to the family." ${ }^{9}$ Working women did not have the agency to be involved in discussions of their own lives. Kessler-Harris set out to establish this agency in Out to Work.

Kessler-Harris' multi-faceted discussion of wage-working women highlights a more intimate space, the home, and moves away from the shop floor or institutionalized looks at labor unions. The culture of American society, its treatment of women within the family and home, and the "problem" of wage-working women are a search for identity rooted in class, culture, and community. In regards to understanding the trajectory of American labor history, Kessler-Harris' focus for Out to Work is unique not only because it is about women and not only because it is about wage-earning women, but because it is about the cultural contexts of wage-working women. The research and writing moves past discussions of worker grievances, pay, and efforts to unionize, toward a more complete and contextual understanding of working women. This is an extension of

\footnotetext{
${ }^{9}$ Ibid., 86.
} 
Gutman and Thompson's critical application of history to understand the whole life of American workers via culture and lived experience.

Arguably, the most influential use of critical assessment of history outside of labor and social history comes from critical theorists and those inspired by Marxist scholar Herbert Marcuse's critique of a one-dimensional, technologically deterministic society. In a short chapter from Philosophy of Technology: The Technological Condition, the editors chose selections from Herbert Marcuse's One-Dimensional Man to provide a critical perspective on the use of technology as a mechanism for control of individual people and groups. Marcuse was very influential in the development of an effective, antiestablishment 1960s counterculture. He inspired an entire generation of students and college organizations, such as Students for a Democratic Society, to re-examine power structures and gentrified purveyors of social power. In a critical analysis that would impassion an entire generation, his critique of technology became a primary work in the philosophy of liberation from a technological society that reinforced forms of hierarchical control in industrial workplaces, as well as in the greater economic, political, and social spheres.

According to Marcuse's critical scholarship on modern American society, in advanced capitalist countries, political and technological domination by statist powers were mechanisms of control that relegated individuals to a system of false needs created by media, advertising, and a corporative system of government. This system of socioeconomic control, fostered by technological development, creates one-dimensional human beings, living in a one-dimensional society. This dystopian society provides for the needs of its people but does not permit the development of opposition to the 
"establishment." Therefore, in Marcuse's one-dimensional society, consumerism and its technological products are used as a means to enchant and create a sense of false consciousness that enslaves modern humans.

When identifying technology's role in social control, Marcuse's critical assessment of the coercive influence of then-contemporary civilization posited, "by virtue of the way it has organized its technological base, contemporary industrial society tends to be totalitarian." ${ }^{10}$ Marcuse offers contemporary analysis to the problem of such forms of control by writing, "the more rational, productive, technical, and total the repressive administration of society becomes, the more unimaginable the means and ways by which the administered individuals might break their servitude and seize their own liberation." 11 While Marcuse identifies technology as a form of control in advanced capitalist societies, he suggests that this relationship does not necessarily need to be true and proffers an alternative, "the technological processes of mechanization and standardization might release energy into a yet uncharted realm of freedom beyond necessity. The very structure of human existence would be altered; the individual would be liberated from the work world's imposing upon him alien needs and alien possibilities." ${ }^{12}$ Fundamentally, Marcuse is arguing that technology could be used as a liberating force to personal and intellectual development but is instead used as a form of control.

Andrew Feenberg's Transforming Technology: A Critical Theory Revisited, published in 2002, borrows from Marcuse's Frankfurt School critical theory and mirrors

\footnotetext{
${ }^{10}$ Herbert Marcuse, "The New Forms of Social Control," in Philosophy of Technology: The Technological Condition, eds. Robert C. Scharff and Val Dusek, (Hoboken, New Jersey: Wiley-Blackwell, 2003), 406.

${ }^{11}$ Ibid.

${ }^{12}$ Ibid., 407.
} 
the project of critical history to argue that, "no fundamental [social] progress can occur in a society that sacrifices millions of individuals to production and disempowers its members in every aspect of social life." ${ }^{13}$ Feenberg's primary contribution to the critique of technology is his "Instrumentilization Theory," which methodologically combines empirical case studies of science and technology with critical theory to posit, "what human beings are and will become is decided in the shape of our tools no less than in the action of statesmen and political movements. The design of technology is thus an ontological decision fraught with political consequences. The exclusion of the vast majority from participation in this decision is profoundly undemocratic." ${ }^{14}$ In many ways, Instrumentalization Theory is akin to critical history in that the empirical nature of scientific and technological criticism is combined with a field in the humanities (philosophy) to offer a unique hybrid of scientifically-subjective analysis. The focus on the empowerment of social actors and the combination of empirical data in the development of social critique parallels the work of E.P. Thompson and the New Labor History. Additionally, and in the same manner as SiH, Feenberg's work also stresses the importance of engagement with present and future social actors who will communicate the significance of critical analysis regarding technological determinism as a relevant model of social critique to drive forthcoming public action and discourse.

Another well-known field in which critical perspectives emerge is education and pedagogical studies. Paulo Freire's Pedagogy of the Oppressed is a classic critical

\footnotetext{
${ }^{13}$ Andrew Feenberg, Transforming Technology: A Critical Theory Revisited, (Cambridge: Oxford University Press), 2002, 3.

${ }^{14}$ Ibid.
} 
pedagogy text, which argues that literacy and educational programs must begin with the radicalization of education. Students, Freire argued, must be educated in their own selfinterest and from their own class backgrounds. This type of educational perspective imbues students with a sense of identity, class-consciousness, and critical inquiry that fosters a radicalization of traditional educational paradigms. Influenced by the abject poverty he saw in South and Central America, Freire noted the need for drastic changes in the socioeconomic and cultural lived-experience of students. Freire's basic understanding of education, top-down and perhaps Hegelian at its roots, is the foundation of the bookoppressed and oppressor. He situated the necessary changes for education in dialectical Marxist terms, and proffered revolutionary goals situated within an egalitarian and progressive educational system. ${ }^{15}$

Howard Zinn also offered a critical history of education in the United States in his Howard Zinn on Democratic Education. Focusing on topics such as "schools and the manufacture of mass deception," "Columbus and Western Civilization," "Being Left: Growing-up Class Conscious," and the "Federal Bureau of Intimidation,"16 Zinn borrows from his earlier work in A People's History to craft an effective argument against traditional and oppressive forms of top-down educational paradigms and institutions. In this work, Zinn's style of writing utilizes and asserts the voice of ordinary people as the primary historical subjects in crafting the story of America's failing and unjust educational system. Zinn also seeks to challenge past educational paradigms that pacified

\footnotetext{
${ }^{15}$ Paulo Freire, Pedagogy of the Oppressed, $30^{\text {th }}$ Anniversary Edition, translated by Myra Bergman Ramos, (New York: Bloomsbury Academic, 2000).

${ }^{16}$ Howard Zinn and Donald Macedo, Howard Zinn on Democratic Education, $1^{\text {st }}$ ed., (Boulder, Colo.: Paradigm Publishers, 2008).
} 
student-citizens. The basic project of Zinn on Education is to foster "a greater ability to read reality critically and accurately." ${ }^{17}$ First, foremost, and perhaps most prescient, is Zinn's critique of the reactionary theory of classlessness in the American classroom. In Zinn on Education, he creates a nuanced dialectic and examines the basic contradictions of class and education when he writes, "these lies [about war specifically and governmental propaganda broadly] and contradictions are more readily embraced by the educated class to the degree that the more educated and specialized individuals become...[less conscious of reactionary education and] fail, sometimes willfully, to read reality critically... and in their roles as functionaries of the state, they propagate these same lies." 18

Noam Chomsky has also contributed a work on libertarian left iterations of education in Democracy and Education, but his work employs a hybrid of historicism and positivism to move toward a form of democratic educational redress. The first section of the book focuses on Chomsky's previous work in linguistics, which is grounded in hard science and the anthropological/biological study of evolutionary human development. The second part of the book focuses Chomsky's social theory in regards to education and his commitments to left libertarian philosophy. This section of the book discusses a "humanist conception of education." Chomsky grounds his argument on the importance of work as life force in the scholarship of noted analytical philosopher, and humanist, Bertrand Russell. In his theorizing about the nature of educational work,

\footnotetext{
${ }^{17}$ Ibid., 5.
}

${ }^{18}$ Ibid., 7. 
Chomsky admits that he is borrowing from early Marxist conceptions of grand narratives that predict higher forms of social organization.

Advocacy for critical examination and critique of traditional forms of scholarship is an interdisciplinary endeavor, and one scholar in particular has examined critical studies on class in rhetoric. An example of critical rhetorical theory and the development of working-class agency and identity can be found in the work of William DeGenaro, an Associate Professor and Director of the Writing Program at the University of MichiganDearborn. In a chapter of Who Says?: Working-Class Rhetoric, Class Consciousness, and Community, DeGenaro argues that "working-class rhetorics explicate the class struggle as it exists in rhetorical texts, paying attention to what rhetors say regarding social class and attempting to situate the discourse of those rhetors in their contemporary context." ${ }^{19} \mathrm{He}$ goes on to write, "working-class rhetorics agitate and antagonize the static words on pages of rhetorical texts and suggest contemporary scholars invent their own classconscious readings of such texts. ${ }^{20}$ Given that he proposes such strong correlation between rhetorical theory, the working-class, and the present, DeGenaro seems to indicate that a working-class study of rhetoric intends to fill the same purpose as critical history, but in a more theoretical manner.

Perhaps no writer in the Humanities has better conveyed the power of critical perspective on a historical event than Dr. Hunter S. Thompson. His Gonzo Journalism provided one of the most cogent descriptions of a historical era through the subjectively

\footnotetext{
${ }^{19}$ William DeGenaro, Who Says?: Working-Class Rhetoric, Class Consciousness, and Community, Pitt Comp Literacy Culture Series, (Pittsburg, Penn.: University of Pittsburg Press, 2007), 6.

${ }^{20}$ Ibid., 6-7.
} 
related experience of historical actors. When reflecting back on the "Hippie" movement of the late 1960s while attempting to chronicle the death of the American Dream in his celebrated but controversial Fear and Loathing in Las Vegas, Thompson wrote:

History is hard to know because of all the hired bullshit, but even without being sure of 'history' it seems entirely reasonable to think that every now and then the energy of an entire generation comes to a head in a long fine flash, for reasons that nobody really understands at the time-and which never explain, in retrospect what actually happened.

There was a fantastic universal sense that whatever we were doing was right, that we were winning...And that, I think, was the handle...that sense of inevitable victory over the forces of Old and Evil. Not in any mean or military sense; we didn't need that. Our energy would simply PREVAIL. There was no point in fighting... on our side or theirs. We had all the momentum; we were riding the crest of a high and beautiful wave...so now, less than five years later, you can go up on a steep hill in Las Vegas and look West, and with the right kind of eyes you can almost see the high-water mark...that place where the wave finally broke and rolled back. ${ }^{21}$

Contained in Thompson's quote is a particular lived experience that captures the feeling, tone, and passion of a movement determined to bring about social justice. And Thompson knew his place in this story because he was the inventor, or at least the most well-known practitioner, of a "Gonzo" style of journalism that was what cultural

${ }^{21}$ Hunter S. Thompson, Fear and Loathing in Las Vegas: A Savage Journey to the Heart of the American Dream, (Knopf Doubleday Publishing Group, 1971), 68-69. 
anthropologists might term "emic" in its methodology_Thompson's was a participatory journalism. Biographer Dr. Douglas Brinkley compared Thompson's writing to that of Thompson's literary idol, F. Scott Fitzgerald by offering the comparison, "the Great Gatsby was filled with anger, that the whole deal in American life was rigged. Hunter identified with Fitzgerald more than any other writer, the difference is Fitzgerald would look in on the candy store window, look in on the storefronts of the rich-Hunter wanted to smash the windows."22

Thompson's life work was a type of participatory journalism that was subjectively crafted to fulfill the goals of placing readers inside the story. Yet, the data generated from Thompson's work became a type of filtered empirical realism offering readers an insideout analysis of events Thompson covered for various magazines and newspapers. This filtered style of writing became incredibly powerful, and though it was not objective reality by any means, Gonzo Journalism contained a strange type of veracity. The quasitruth quality of Gonzon journalism caused Frank Mankiewicz, who was George McGovern's Presidential campaign manager, to state that "of all the correspondents [covering the 1972 Presidential election], Thompson was the least factual, but most accurate." ${ }^{23}$ Much like Thompson's window-smashing perspective, SiH intends to redefine the boundaries of historical inquiry and utilizes an interdisciplinary methodology in this endeavor.

\footnotetext{
${ }^{22}$ Alex Gibney, Director, Gonzo: The Life and Work of Dr. Hunter S. Thompson, Magnolia Home Entertainment, 2008.

${ }^{23}$ Ibid.
} 


\section{Interdisciplinary Methodology}

Solidarity-inspired History uses empirical methods of data gathering, but fosters an emic or inside-out subjective analysis of historical events, which posthumously develops agency, defines often-times denied identity, and empowers historical actors that have been overlooked or silenced by traditional historical narratives. The utilization of primary documents generated by those engaged in the fight for social justice and the study of material culture are two of the primary methodological tools on display in this dissertation's corrective of the past. Previous works on the 1916 Strike do not employ such a critical or interdisciplinary methodology and, in general, published research and writing regarding the 1916 Minnesota Iron Strike is rather limited. There have been a scattering of articles on the event such as Robert M. Eleff's, “The Minnesota Miners' Strike against U.S. Steel” and Neil Betten's, “Riot, Revolution, Repression in the Iron Range Strike of 1916," and a tertiary history published on-line to compliment a description of the Minnesota Historical Society's archival holdings relevant to the strike, but book or dissertation length treatments of the 1916 Strike are non-existent. More numerous are histories of Minnesota iron mining. Perhaps the best known is Marvin Lamppa's foundational Minnesota's Iron Country: Rich Ore, Rich Lives. Lamppa has a small section on the 1916 Strike in the book but relies on newspaper accounts of the strike and secondary sources to give a short timeline of the strike and its major events. Primary research outside of newspaper accounts partial to mining companies is especially scant in his account of the 1916 Strike.

Projecting out to the great region of northeastern Minnesota, there is a rather small canon of scholarly texts on working-class history. Of these, Arnold Alanen's 
Morgan Park: Duluth, U.S. Steel, and the Forging of a Company Town is one such analysis of labor-management relations in the Lake Superior area. An insightful ideological and critical history of the northeastern Minnesota area is Richard Hudelson and Carl Ross' By the Ore Docks: A Working People's History of Duluth. Another work that examines a specific event in the history of Duluth, Minnesota, is Michael Fedo's The Lynchings in Duluth. This work takes a singular event and draws upon it to give context to the Progressive Era and northeastern Minnesota's social history during this temporal period.

While previous works on the 1916 Strike and northeastern Minnesota's history have been valuable contributions they have mostly been descriptive in nature. Critical interpretations of northeastern Minnesota's history are few and far between. This perhaps indicates that the technical aspects of "doing" critical history with an eye on the future can be challenging. The field of history occupies an interdisciplinary crossroads between a science-like empiricism and a subjectively generated humanities perspective; uniquely subjective, but dependent on the lived experience, history is a sensory distillation of phenomenon by the actors, institutions, and organizations that are being researched. It is through this empirical, yet subjective inquiry that historical actors can breathe life into the present. It is important to understand that these subjective expressions of historical research are not truth statements, but rather perspectives gained from research and analysis. Such viewpoints will surely engender a bias toward the principal perspective, but a dedicated enunciation of bias allows the reader to critically examine and situate this perspective into a context that illuminates the complexity of historical actors and the difficult situations proffered by a complex past. 
Artistic, cultural, and physical artifacts of socially produced materials, often seen as the purview of archaeology and the social sciences, can add greatly to the scholarship in a humanities driven labor history. Thus, this dissertation argues that the critical history, methodological tools, and calls for solidarity across the temporal divide, which provide the framework for this dissertation's $\mathrm{SiH}$ perspective, can only be located in an interdisciplinary context. The explanatory and transformative power of subjective history based on the use of empirical evidence as a guiding methodology, which advocates proactive, progressive social change, has a broad application to the critical study of fields in the humanities and the sciences. Believing that the purpose of scientific humanism is to promote the ethical implementation of scientific methodology (in this case empiricism) for the common good, then the concrete wall between what is scientific and what is humanist must be breeched, even exploded. SiH provides a framework in which to begin this dialogue and offers a way to, as Marx might have concluded, "change it." Coalescing the disciplinary fields of the humanities and social sciences to empower social actors while bridging the historical gap in solidarity provides contemporary activists with a comprehensive understanding of the plight of disempowered historical actors by providing a roadmap of past struggles that can inform future actions. This only happens through the examinations of lived experience that transcend the rigidity of scholarly disciplinarity.

As part of the dissertation's interdisciplinary SiH framework, the methodological approaches employed in researching the 1916 Strike will be clearly articulated in four section introductions. The elucidation of these methodological approaches provides an explanation regarding the "practices" that make this dissertation, and $\mathrm{SiH}$, unique. 
Blending historical research of documents, landscape, media offerings, historic images, oral history, material culture studies, and rhetorical analysis of these primary documents, the dissertation will offer an interpretation of the 1916 Strike that is comprehensive, but from the perspective and in the voice of those working-class individuals and organizations who lived the events. Each methodological "tool" will provide a unique aspect to the dissertation's interdisciplinary character: the utilization of historical landscapes will help to situate the Iron Ranges in a spatial and temporal context giving background to the Iron Ranges' working-class populations; examination of primary texts in multiple languages will highlight previously unexplored "written" histories of immigrant striking populations and the development of their identity as class-conscious American workers; oral histories will provide an intimate picture of life on Minnesota's Iron Ranges; studying the rhetorical strategies of the IWW will identity the methods of communication and rhetorical appeals used by organizers in their attempt to successfully transmit the IWW's ideology, goals, and working-class ethos to the Iron Range's multiethnic audience; and, lastly, material culture studies will afford an understanding of the physical structures and tangible items of discontent produced by supporters of the IWW. While the aforementioned fields are the primary modes of inquiry for this dissertation's $\mathrm{SiH}$ framework, other compatible fields can include but are not limited to: archaeology, archival studies, geology, gender studies, historical preservation, engineering history, literature studies, and political science.

The dissertation is unique because it is based in a truly interdisciplinary perspective that forms a distinctive narrative, which paints a vivid and nuanced image of the efforts to organize the Iron Ranges' immigrant laboring masses, how those efforts 
influenced and shaped the events of the 1916 Strike, and how this labor conflict so drastically affected United States anti-immigration and anti-union policy in the World War I era. Based in such an interdisciplinary perspective, $\mathrm{SiH}$ can be a powerful tool in understanding the critical intersections between economic relations, immigrant lives, progressive movements, and social justice. For such critical studies of history and historiography, this demands a nuanced examination of how historical actors who have been alienated, disenfranchised, excluded, marginalized, silenced, and/or subjugated in previous texts have had their voices restored in an appropriate manner using suitable methodological means with primary sources and/or secondary texts. When examining usage of other forms of critical inquiry such as critical pedagogy and critical theory, one comes to understand that "critical studies" are inherently a function of pointed, positive, and provocative criticism and critique. This dissertation's structure allows for such a critical perspective and highlights the methodological means used to distill past workingclass voices into the present.

\section{Structuring the Dissertation}

Divided into four sections, this dissertation brings together perspectives from the humanities and social sciences to provide a comprehensive analysis of the strike, and the strike's principle working-class actors. The sections on landscape, identity/ideology, and cultural history provide a background for the 1916 Strike. The dissertation's last section, comprised of three chapters on rhetorical studies and labor history, are a type of culmination of the previous sections and chapters' topical content. The Iron Ranges' physical and social landscapes, the formation of identity/ideology in the Ranges' immigrant populations, and the cultural history of the IWW and its rank-and-file are 
highlighted in the earlier sections of the dissertation so that these important aspects of the strike can be better understood in the dissertation's examination of specific actions, events, and people during the 1916 Strike. Fulfilling the aims of SiH, this work will provide commentary on how the plight of the 1916 strikers, as historical actors, can advise, inform, and teach contemporary social actors in the ongoing fight for social justice. This analysis on how the past can inform the present and change the future can be found in vignettes that begin each section.

The dissertation's section on landscapes, comprised of Chapters 1 and 2, is an introductory piece that explores the land, people, and places involved in setting the historical stage for the 1916 Strike. It is a section that establishes the context for workingclass "life" on the Minnesota Iron Ranges. Exploring such aspects of landscape, work and social life, and labor-management relations, the section is meant to examine "power" on the Range. This examination of influence and control is done to establish the skewed balance of socioeconomic relations that defined the particular experiences of the Iron Range's mostly immigrant population.

Chapters 3 and 4 form the corpus of this dissertation's section on identity and ideology. Picking up on the social setting for unrest this section will analyze the formation of identity and ideology in the Iron Range's working-class population. Of especial interest in Chapter 3 is the dissertation's theoretical development of the concept of working-class identity through education and literacy efforts; termed in this dissertation as the "3Rs of proletarian literacy." To highlight and demonstrate the 3Rs of proletarian literacy, the dissertation turns to the establishment of literacy and pedagogical programs at a Finnish immigrant educational institution known as the Work Peoples' 
College. Additionally, cultural expressions of the IWW's educational efforts, such as the singing of labor songs, provide historical analysis of a media rich union, and how the IWW communicated its industrial unionist message through the teaching of classconsciousness and solidarity to a rank-and-file composed of immigrants from many different nations.

Strike dialectics and the ideological foundations for a controversial union tacticsabotage-are the main topics of discussion for Chapter 4. This chapter introduces the largest employer on the Ranges, the Oliver Iron Mining Company, which was a subsidiary of the giant United States Steel Corporation. The history of sabotage as a measure of gaining control of industrial workspaces is explored, while the IWW's debate on and use of industrial sabotage in the class struggle is also highlighted. The chapter then examines the use of sabotage in the Lake Superior mining industry. Early strikes such as the 1904 Fayal Mine Strike, the 1907 WFM-led Mesabi Iron Ore Strike, and the 1913-14 Copper Country Strike (including IWW influence in the Western Federation of Miners union and the Finnish Socialist Federation split in 1914) will be explored.

Included will be the IWW's contextual reasons for the application of sabotage as a tool in the class struggle. Sabotage, often termed the conscious withdrawal of efficiency, was especially employed by the Wobblies in times of labor strikes, which could be seen as the ultimate withdrawal of efficiency on the job. Sabotage and its definitive expressionlabor strikes—-were a type of direct action tactic, and the analysis of the IWW's use of this strategy will come primarily from primary source documents generated by the union and its organizers. 
The dissertation's third section consists of Chapters 5 and 6 , which utilize cultural history as a tool of analysis in examining the IWW and their cultural apparatuses. The general examination of the IWW's union culture will lead to a specific analysis of this culture in regards to the 1916 Strike. Chapter 5 examines two different visual artifacts from the IWW's organizational activities. The first artifact, Father Hagerty's Wheel, is presented as a counterargument to the critique that the IWW was a haphazardly organized union. The second visual artifact is a radical cartoon published in the International Socialist Review, which highlights the loss of free speech and repression on the Mesabi Iron Range during the strike. In analyzing these two visual, cultural artifacts, this chapter argues that the IWW and its deftly crafted cultural symbols skillfully purveyed information to the union's unskilled, often illiterate or English as a second-language members. The chapter will discuss the IWW's attempts to communicate complex ideas and goals to their rank-and-file, which consisted of multiple ethnicities, such as Finnish, Italian, Croatian, and Slovenian populations. An examination of the IWW's multifaceted union culture provides a better understanding of the initial obstacles in organizing northeastern Minnesota's mineworkers.

Material culture, a sub-field of cultural history, is the subject of Chapter 6 . Especially of interest in the examination of material culture are social spaces of discontent, which are exemplified in the case of the 1916 Strike by the area's Finn Halls. Focusing on the Hibbing Workers' Hall, Virginia Socialist Opera House, and Nashwauk Socialist Hall, the chapter will argue that these spaces of working-class culture and dissent were essential to the IWW's development of a working-class culture on the Iron Range during the strike. Taken from fieldwork of extant physical structures such as 
Virginia, Minnesota's former Socialist Opera House building (now a union local office building), research with Sanborn Fire Insurance Maps, oral histories, and historic photographs, analysis for this chapter will conclude that in the documentation of working-class communities' material culture, the examination of the three-dimensional historical record is a companion to the often-times scant, suppressed, or non-existent archival record.

This dissertation's last chapters, Chapters 7, 8, and 9 comprise the work's final section. These three chapters examine the events of the strike via rhetorical studies and labor history lenses using English language and accompanying ethnic language sources. Some of the archival materials examined are: a strikers' song in the Finnish immigrant newspaper Sosialisti, International Socialist Review articles on the strike, dockworkers' sympathy strikes in Duluth/Superior and Two Harbors, Minnesota, and analysis regarding the organizational work of prominent IWW organizers such as Frank Little, Elizabeth Gurley Flynn, and Carlo Tresca. A rhetorical analysis of these historical actors and their efforts at engaging striking workers will involve an exploration of the metis, or cunning intelligence, involved in agitating and organizing Iron Range workers during the strike.

Especially significant and new to the scholarship on the 1916 Strike is Chapter 8's examination of the role of Minnesota's Republican Governor Joseph A. A. Burnquist in the strike. It appears from primary documents that Burnquist, at the bequest of the mining company officials, issued an order that threatened legal action against the IWW in an attempt to literally railroad the union's organizers from the Minnesota Iron Ranges. These documents demonstrate that Burnquist issued the order after covert meetings with mining company officials and that this meeting was granted because mining companies 
were not able to convince local businessmen on the Iron Range to organize a deportation of IWW organizers during the early days of the strike. The Governor's proclamation for "Law and Order" was aimed squarely with the goal of deporting, jailing, and ultimately silencing members of the IWW to end the strike, which directly affected the ability of mining companies to break the strike. Perhaps more insidious was the potential way in which the IWW organizers were "set-up," as Burnquist's proclamation provided the mining companies with the sought after legal recourse to run the IWW off the Ranges. Chapter 8 goes into great detail regarding this conspiracy to rid the Ranges of the IWW, and quotes the documentary record at length in assessing the behind the scenes chicanery and corruption that led to the deportation and imprisonment of IWW organizers.

Lastly, the dissertation's "Conclusion" will provide a final contextual look at the strike and its national consequences. It will conclude that the strike had national significance in relation to establishing state and federal anti-syndicalist laws, and provided momentum for anti-immigration and anti-union legislation within the United States prior to, during, and after World War I. The chapter will also argue that while the strike occasioned hard times and bitter industrial relations on the Minnesota Iron Range for a time after, a new class-consciousness arose that made the Minnesota Iron Range a bastion of union influence up to present day. 


\section{Section: Landscape, Community, and Labor}

\section{A Solidarity-inspired History Vignette: Raw Power Revisited}

Dateline: Virginia, Minnesota, Sunday, October 12, 2014-according to the Minneapolis Star Tribune, the Minnesota Department of Transportation is desperately trying to determine a re-route of one of Minnesota's main thoroughfares, Highway 53, which runs through the heart of the Iron Range. The reason for finding a permanent alternative route for Highway 53 is that the current roadway is on mining company owned land, and the companies have determined that there is paying ore underneath the gray road surface of one of the Range's main transportation arteries. The open pit mine needs to expand; the road needs rerouting: the raw power of mining companies to alter the landscapeeconomic and social—is on display once again.

As the Star Tribune's article relates, "with older mines played out, the taconite under the roadway is worth hundreds of millions of dollars and mining it could extend the life of an operation that employs 514 people." ${ }^{24}$ The Minnesota Department of Transportation, which had been leasing the land for the roadway by the Auburn Pit Mine, has three options for rerouting the highway, and all are expensive to Minnesota tax payers. The bill for moving Highway 53 is estimated to be between $\$ 400$ and $\$ 600$ million, but this estimate from the Minnesota Department of Transportation does not take into account the cost of rearranging lives and businesses in the wake of moving several miles of a vibrant highway business and residential corridor. Caught in between the

${ }^{24}$ Jennifer Brooks, “HWY 53 Re-route is Minefield,” Star Tribune, Section A, October 12, 2014, 10. 
bottom-line interests of mining companies and the bureaucracy of the state, the people of the Iron Range and their livelihoods are seemingly always in flux.

This is not the first time mines and mining companies have had such an incredible impact on northern Minnesota's economic and social landscape. In the early $20^{\text {th }}$ century, the entire town of Hibbing was relocated after the Hull-Rust Mine pit was slated for extension. North Hibbing, as it became known, turned into a ghost town in less than two years as buildings were either moved two miles in a southerly direction to the small hamlet of Alice (later renamed Hibbing), or demolished as the impending walls of the Hull-Rust pit devoured the streets, lights, and structures of the once booming metropolis making way for what would become the world's largest open pit iron ore mine at over three miles in length, a mile in width, and almost 600 feet in depth. ${ }^{25}$ "New" Hibbing did thrive, but the absolute power of the Oliver Mining Company was on full display. People and businesses had their lives thrown into upheaval as crews moved the town building by building, over 188 structures, over two years duration.

Virginia, Minnesota's original main street suffered a similar consequence as the Rouchleau Mine's pit expanded. In perhaps the most abrupt end to a historic main street in Minnesota, the Queen City's one-time primary business thoroughfare ends in a steel barrier. To go any further on Virginia's historic main street would require wings as the pit of the Rouchleau Mine falls hundreds of feet to the mine's bottom, less than thirty feet from the end of downtown Virginia's one-time center of social activity—Chestnut Street. The pit engulfed most of Virginia's eastern border, and the once vibrant downtown scene,

${ }^{25}$ Minnesota Historical Society, MNOpedia, "The Relocation of Hibbing, 1919-1921," http://www.mnopedia.org/event/relocation-hibbing-1919-1921, accessed October 14, 2014. 
home to massive brick and concrete structures, raucous working-class bars, and architecturally ornate hotels almost died in the bust cycles of the 1970s and 1980s. Faced with a dead end main street, businesses moved out of the historic downtown area, relocating to Highway 53's borders on the edge of town. But, quite ironically, now some of these Highway 53 businesses face an uncertain future in the current rerouting of Highway 53.

All of the aforementioned circumstances, historic and contemporary, demonstrate the absolute raw power of mining companies on the Minnesota Iron Ranges. Literally, mining companies and the men who run them had, and have, the power to determine the fate of not only individual workers and industrial spaces, but also entire communities. From the movement of billions of tons of earth, to the demolition of entire cities, to the social and political engineering of pro-mining civic institutions, the raw power of mining companies to shape the Iron Range's economic, cultural, political, and physical landscape was and continues to be inescapable. In the midst of this pervasiveness, it was always a struggle for "ordinary" people to have their voices heard on events and issues that would so profoundly affect and effect their lives. There have been those who have attempted to mitigate or downright thwart this power over the years, but few have had success in such endeavors until the Progressive political era and the radical unionism of the early $20^{\text {th }}$ century.

\section{Section Introduction}

The opening section of this dissertation examines the varied landscapes of the Minnesota Iron Ranges to provide context for the 1916 Strike. Included in this section on landscape 
are the cultural and social landscapes of historical actors as well as the physical spaces of industry and work that influenced this great clash between labor and management. The study of landscape in this section seeks to understand the interactions between people and place as workers attempted to find a voice in tightly controlled and corporative physical and social settings. To better understand the contextual significance of the Iron Ranges' intertwined landscapes: communities, laboring peoples, and cultural and physical settings, this section turns to the scholarship of three authors who have put landscape at the center of their academic work.

Understanding landscape as a setting for the historical actors and actions of the 1916 Strike demands that we first understand the physical spaces in which these people lived, worked, went on strike, and died. Certainly, this landscape was dominated by industrial corporations such as U.S. Steel, but perhaps just as demanding was the actual physical setting of Minnesota's Iron Country. Cold, isolated, and unforgiving are qualifiers that define this hardscrabble region. However, as environmental historian Dr. William Cronon argues in his book, Nature's Metropolis: Chicago and the Great West, a hinterland such as the Minnesota Iron Ranges is dependent upon a metropolis, and that metropolis is, in turn, reliant on the hinterland. Cronon's study focuses on Chicago and its relation to Midwestern farmlands. Cronon writes of this relationship, "I wondered whether it made sense—-historically or environmentally—to treat city and country as isolated places...I began to see that the word 'city' depended for its meaning on its opposition to the word 'country,' and vice versa." ${ }^{26}$ And, much like Chicago was the

${ }^{26}$ William Cronon, Nature's Metropolis: Chicago and the Great West, reprint edition, (New York: W.W. Norton \& Co., 1992), 8. 
metropolis to the Midwestern United States' hinterland, Duluth operated as the metropolis that shared a symbiotic relationship with the Iron Ranges' hinterlands.

In examining and understanding the economic and physical landscapes of the Iron Ranges, the influence of Duluth's artificial, human made connections to the region is significant. The physical material, iron ore, which brought wealth to capitalists, while occasioning the exploitation of thousands of immigrants, was insignificant if not for Duluth/Superior and its ports. Likewise, the region's railways or as Cronon would term them, "artificial corridors," were important as they connected the raw commodity of the Ranges through a dense wilderness to the docks that shipped the ore to steel mills further down the Great Lakes. Cronon's "Metropolis-Hinterland Model” explains the relationship between seemingly disconnected physical spaces and conveys that these physical and industrial landscapes were incredibly important to the development of labor and management relations on the Ranges.

Cronon's model can also be extended to cultural, political, and social landscapes. Duluth's importance as a social and political center had great significance for the 1916 Strike. Communications between mining company managers in Duluth and their subordinates on the ground in Range towns determined outcomes during the Strike. Duluth's importance to the IWW was significant as well as the first organizers on the scene in Range towns came from Duluth. And, perhaps most importantly, when the Governor of Minnesota made it possible to deport the IWW's leaders from the Ranges (discussed in Chapter 8), Duluth was the location where trials and incarceration of a number of the IWW's most dynamic organizers occurred. The same artificial corridor that saw the transportation of raw iron ore from Range mines to Duluth's docks was the 
railway that spirited IWW organizers from the Ranges to waiting jail cells in Duluth. Mining company managers, IWW organizers, and events on the Iron Ranges, of course, played a major role in the strike, but so did Duluth as a metropolis. Its law enforcement officials, corporate headquarters, and jail cells played an equally significant role as they linked antecedent events that happened in the hinterland to significant outcomes that occurred in the city. Thus, Cronon's "Metropolis-Hinterland Model" provides a heuristic device to understand the important interconnected relationship between the Iron Ranges and Duluth.

Also significant to understanding the 1916 Strike are immigrant cultural landscapes of discontent. Chapter 6 of this dissertation analyzes these places and spaces in detail, but this section provides the context for such an analysis. Minnesota's Iron Country was a land of immigrants who brought their own traditions and cultural values with them to America. Once on the Iron Ranges, the reality of being in an industrial, corporate-controlled milieu forced immigrants to re-evaluate their cultural, economic, and social circumstances. To better deal with these forced realities, immigrants sought to recreate familiar physical and social surroundings amidst the novelty of their newfound landscapes. In his article, "Considering the Ordinary: Vernacular Landscapes in Small Towns and Rural Areas," Dr. Arnold Alanen highlights a passage from the Vernacular Architecture Forum that asserts, "vernacular architecture comprises the dwellings and all other buildings of the people. Related to their environmental contexts and available resources, they are customarily owner- or community-built, utilizing traditional technologies. All forms of vernacular architecture are built to meet specific needs, accommodating the values, economies, and ways of living of the cultures that produced 
them." 27 The power of vernacular forms of architecture and landscapes to reinvent, sustain, or create new identities in an adopted homeland is significant when understanding the sociocultural lives of immigrant workers on the Iron Ranges.

In such novel landscapes, these immigrants provided the counterargument to American capital's requirement of assimilation, and immigrant social halls, boardinghouses, co-operatives, and domestic spaces left a significant cultural footprint on the Iron Ranges. Interpreting this footprint as a cultural landscape of discontent focuses the analysis of labor-management relations in a concrete manner. Cultural expressions of dissent happen in populations of people struggling to create a voice in a controlled setting, which contains industrial displays of power and prestige created by the "bosses." The Oliver Iron Mining Company's offices in Hibbing were professionally designed and constructed to display a sense of control, professionalism, and power. Conversely, vernacular cultural landscapes express a disregard for prevailing notions of power by presenting buildings and structures made by workers in their own interests. During the 1916 Strike, these buildings constituted the physical embodiment of the immigrant working-class community as they hosted meetings, set the stage for street parades, and hosted the funerals for slain fellow workers. Thus, a study of the Ranges and the 1916 Strike should include analysis of the vernacular aspects of culture that defy the formalization of form and function and regard cultural expression of buildings and landscapes as a registered complaint against the assertion of privilege and power.

\footnotetext{
${ }^{27}$ Arnold R. Alanen, "Considering the Ordinary: Vernacular Landscapes in Small Towns and Rural Areas," in Preserving Cultural Landscapes in America, eds. Arnold R. Alanen and Robert Z. Melnick, (Baltimore: The Johns Hopkins University Press, 2000), 113.
} 
Much like Cronon's Metropolis-Hinterland Model, Rodolfo F. Acuña's Corridors of Migration, highlights physical interpretations of landscape to study the intersections between industry, people, and the surrounding environment. Acuña describes Corridors of Migration as a work that puts history back into studies of migration, writing, "in many ways Corridors is a return to what makes history different from sociology and political science: it is a synthesis of the memories that connected Mexican laborers to their destinations." ${ }^{28}$ Acuña's model of geographical corridors as a physical space that determined the movement of Mexican mine and agricultural workers is a key component to understanding the struggle of a mobile and often times radical migrant work force. Acuña introduces geography into the study of migrant laboring communities, and this is a significant addition to recognizing the spatial components of critical history. Specifically important to Acuña's historical geography of workers is the corridor effect, and the culturally sanctioned movements for work in the United States.

Much like Acuña's "Corridor Model" of understanding the movements of Mexican workers in the American southwest, there is a corresponding movement model for workers on Minnesota's Iron Ranges. Instead of a corridor, many of the Iron Ranges' workers formed mobile communities of itinerant laborers who traveled in a triangular, seasonal pattern from the Iron Ranges to the Dakota wheat fields to the logging camps of extreme northern Minnesota and southern Ontario, Canada. This section provides the case of Sam Swanson, a worker who was caught in this seasonal work pattern, as a corollary to the subjects of Acuña's Corridor Model.

\footnotetext{
${ }^{28}$ Rodolfo F. Acuna, Corridors of Migration: The Odyssey of Mexican Laborers 1600-1933, (Tucson,
} Ariz.: University of Arizona Press, 2008), xiii. 
It is the important work of this section to provide a background for the rest of this dissertation. The authors and works described above provide the scholarly lenses to better understand the whole lives of workers on Minnesota's Iron Ranges. This section discusses the importance of multiple landscapes because of the significant effects each had in shaping the tinder-dry landscape of the Ranges' labor relations. Mining company exploitation of natural and human resources occasioned a setting that was primed for worker revolt. Metaphorically speaking, all that was needed was a match. The IWW provided such a transformative device, but not without the contextual pieces of immigrant communities, the struggle for union representation, and the fight to bring industrial democracy to an almost completely controlled corporate setting. 


\section{Chapter 1: A Tinder-dry Landscape}

\section{Chapter Introduction: Raw Material, Raw Power in a Tinder-Dry Landscape}

Reddish-orange. Iron. Ore. A raw material in the production of steel, Minnesota iron ore drove the United States' economy in the late $19^{\text {th }}$ and early $20^{\text {th }}$ century. Perhaps no other material meant so much to a nation that was building an industrial legacy in a time of unprecedented economic growth. The building of this legacy benefitted the few, while it exploited the many. For those who applied raw labor power to the mining of raw industrial materials, the meager recompense for dangerous and deadly work was increasingly called into question. The wealth of Wall Street tycoons and robber barons such as Andrew Carnegie, Nelson Rockefeller, and J.P. Morgan was built with the sweat of Minnesota's iron ore mineworkers. Immigrant laborers who were good enough to risk their lives in area mines were not good enough to have a say in their own laboring conditions. This cognitive dissonance, expressed by repeated calls for industrial democracy, occasioned a tinder-dry cultural, economic, political, and social landscape, waiting for a match to light the fires of worker revolt and revolution.

The Industrial Workers of the World (IWW) and their perspective of revolutionary industrial unionism provided such a spark in 1916 when the Minnesota Iron Ranges seemingly were set on fire during a workers' insurrection that lasted four months. There was, however, a context to this uprising. The fanned flames of discontent did not originate with the IWW and the parched relations between labor and management on the Ranges had a trajectory that arced across immigrant communities, labor, and landscape.

Lives on Minnesota's Iron Ranges were almost entirely sculpted by the influence and power of million dollar corporations tasked with the profitable extraction of iron ore 
at the expense of the environment and the people who gave their sweat, toil, and at times, lives, to reddish-orange iron ore. Mined Minnesota iron ore provided the base ingredient for the steel that propelled the United States to victory in World Wars I and II, allowed massive structures in expanding megalopolises to be built up, and provided the transportation vessels to haul grain, cargo, and other foodstuffs down the Great Lakes to hungry populations. These were a few aspects of what iron ore provided for the United States, and while names like Carnegie, Morgan, and Rockefeller get most of the credit for the industrial foresight, strength, and wealth that iron ore created, the men who actually did the work to create this wealth get little recognition. This chapter provides a contextual examination of the communities, cultural activities, and work lives of the historical actors who made up the physical and social landscapes of Minnesota's Iron Ranges.

\section{Minnesota's Three Iron Ranges}

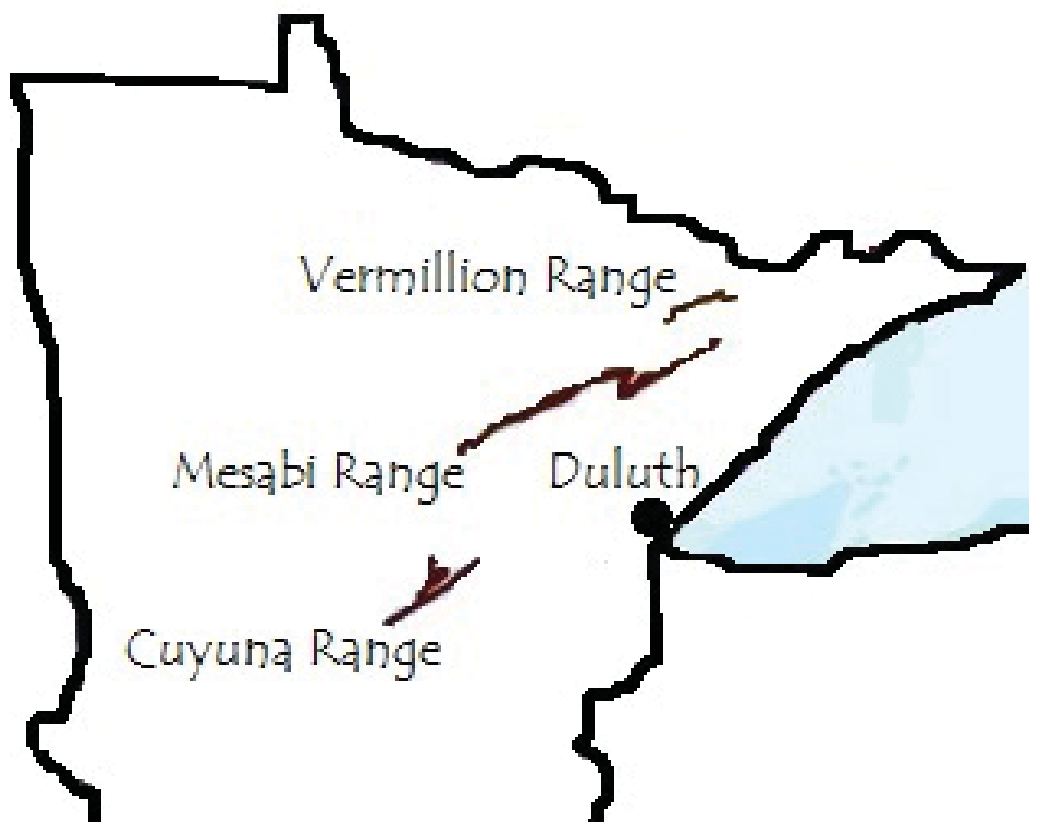

Figure 1.1—Northern Minnesota showing the three Iron Ranges in relation to Duluth-map drawn and labeled by Gary Kaunonen 
Comprised of three separate iron ore ranges, the Vermilion, Mesabi, and Cuyuna Ranges, Minnesota's Iron Country was the workplace for tens of thousands of people in the late $19^{\text {th }}$ and early $20^{\text {th }}$ centuries. The Vermilion Range, the northernmost of Minnesota's three ranges, was the first to support a commercial mine and by 1883 there was full production at the appropriately named Minnesota Mine. Most of the mines on the Vermilion Range were worked as underground properties. Mineworkers sank deep shafts into the Earth, blasted iron ore bearing rock, and hoisted the hard ore rock to the surface. It was dark, difficult, and often deadly work. Mining boomtowns sprung up on the Vermilion to supply the mines and the mineworkers. Tower, Soudan, Winton, and Ely, the Vermilion Range's largest urban area approaching 5,000 people in 1920, were among the Vermilion Range's fledgling urban areas, carved from the rocky, undulating, and dense surrounding wilderness. ${ }^{29}$

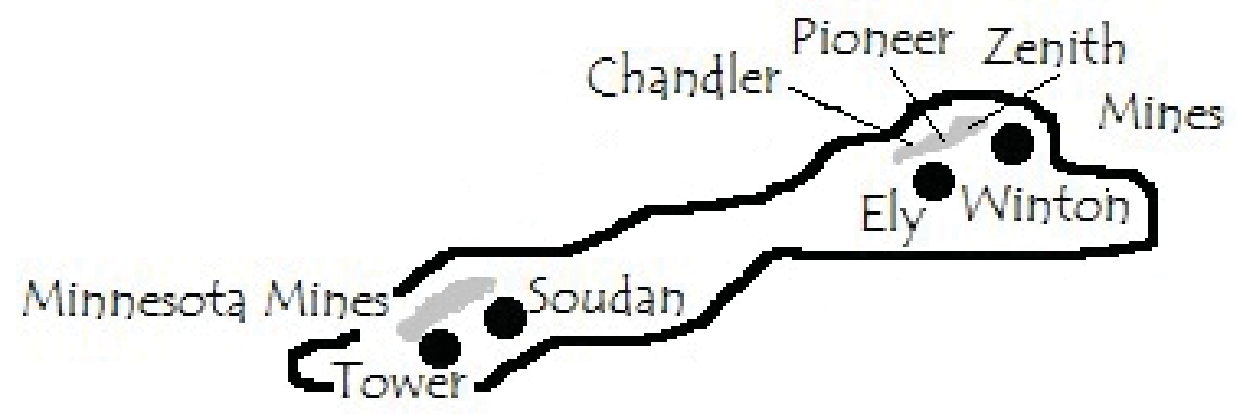

Figure 1.2-Vermilion Iron Range showing principle urban areas and mines, ca. 1900--drawn by Gary Kaunonen ${ }^{29}$ Marvin Lamppa, Minnesota's Iron Country: Rich Ore, Rich Lives, (Duluth, Minn.: Lake Superior Port
Cities Publishing, Inc.), 2004. 
While the Vermilion Range was the site of Minnesota's first iron ore boom, the Mesabi Range ores were the largest both in size and significance. Beginning in the summer of 1890, what would become the world's largest iron range was being explored to determine if there was a possible paying deposit. It was discovered that there were in fact workable ore bodies and a lot of them. Over time, the mighty Mesabi (also seen as Mesaba or Missabe) would stretch in a southwest to northeast line: from Coleraine in Itasca Country, then northeast over the St. Louis County line, dipping only four miles southward at Virginia to encompass mines in the Eveleth area, and then regaining course northeast toward Biwabik. The Mesabi Range stretched for over eighty-seven miles in Minnesota's Arrowhead. ${ }^{30}$

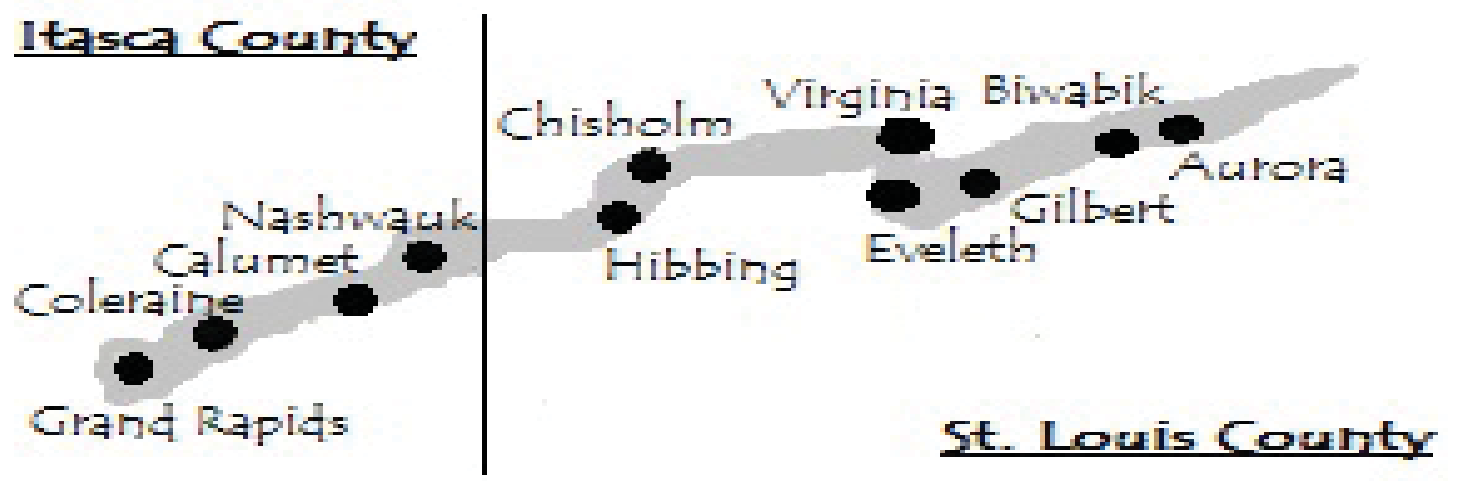

Figure 1.3-Itasca and St. Louis County Urban Centers, ca. 1910-Map drawn by Gary Kaunonen

The Mesabi differed from the Vermilion in that the ore bodies were often close to the surface, soft, and at times located in relatively sandy soil. Thus, the mines of the Mesabi often started as underground ventures and then switched to open pit mines. In such cases where pit mines developed, the top layers of non-ore carrying material had to

${ }^{30}$ Ibid. 
be "stripped" to reach the ore. Stripping crews became common sights all along the Mesabi. Others mines began as pits and grew to astonishing widths, lengths, and depths_-human made Grand Canyons. One pit mine, the Hull-Rust-Mahoning, grew to be the largest iron ore pit mine in the world at over three miles in length, a mile and a half in width, and depths diving to over 600 feet.

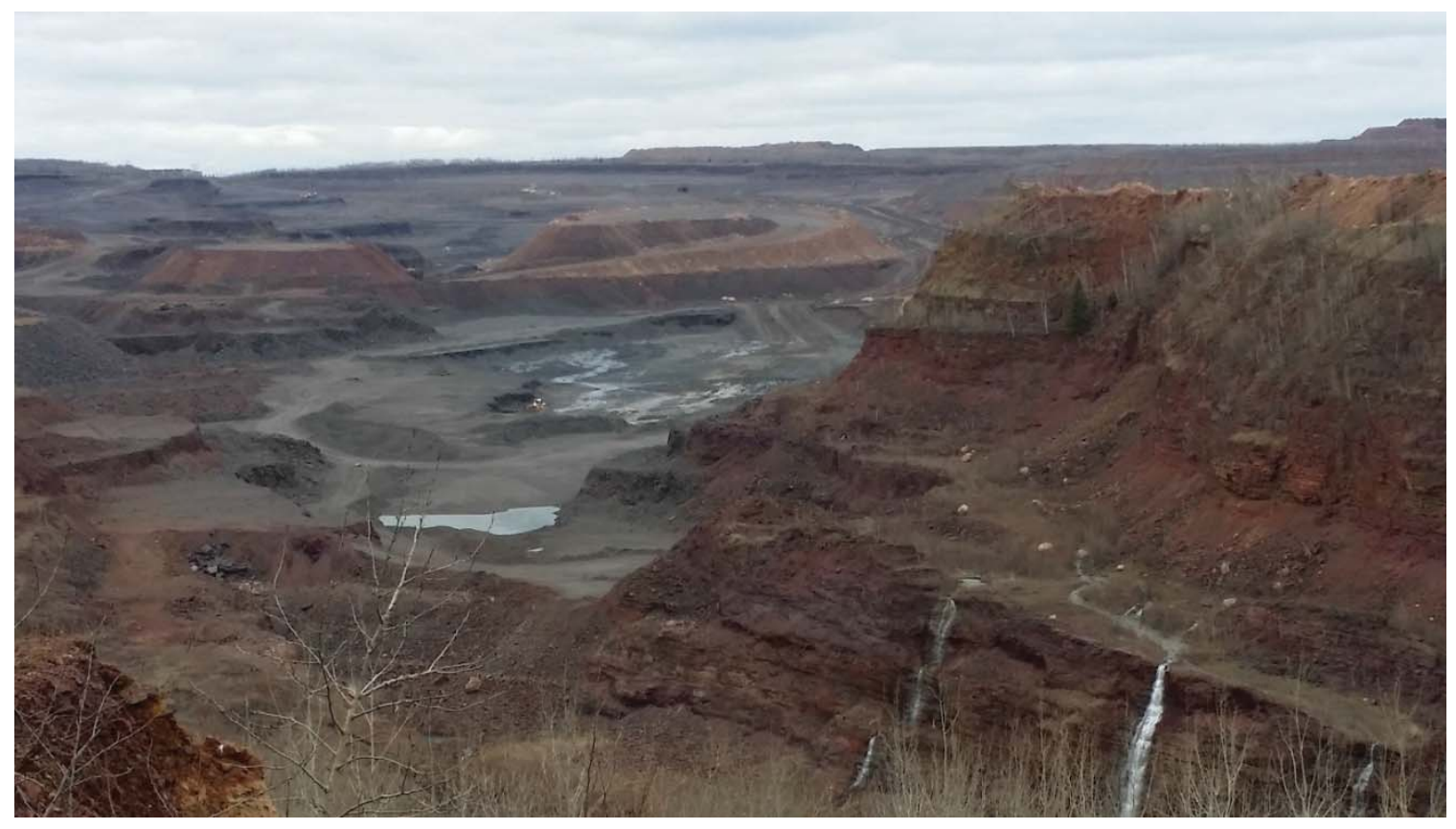

Figure 1.4--Contemporary image of the Hull-Rust-Mahoning Pit in Hibbing-Image captured by author, May 2014

With mines growing to such lengths and depths, mechanization was the mode of mining on the Mesabi. Huge steam shovels that swallowed ore carrying Earth, attended to by mostly immigrant crews, liberated the Mesabi's riches. Locomotives on narrow gauge rails steamed out of the massive pits carrying the precious cargo. Everything seemed to be big on the Mesabi, including the municipal areas. Hibbing, the largest city on the Range, was located at the western end of the Range and grew to almost 20,000 people 
(including the surrounding mining locations) by the 1920s. Virginia, approaching 10,000 persons, was the Range's "Queen City" and the cultural and social hub of the eastern side of the Range. The Mesabi Range made Minnesota mining famous. ${ }^{31}$

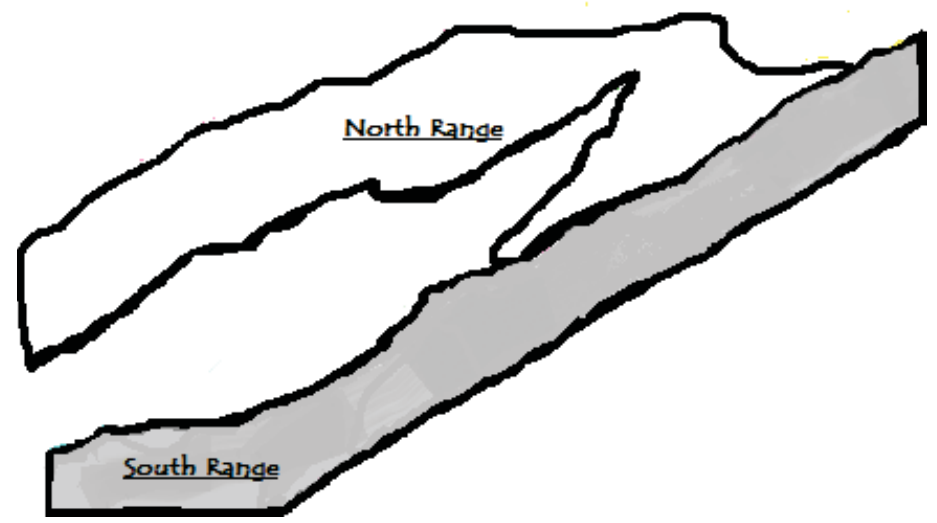

Figure 1.5-the North and South Ranges of the Cuyuna Iron Range-Map drawn by Gary Kaunonen

The last of Minnesota's three iron ranges to be discovered was the Cuyuna Range, located among the swampy flat lands, shallow lakes, and surrounding farm lands of Crow Wing County. Known locally as "bog ore," the Cuyuna had some of Minnesota's best manganese iron ore and for a time was a leading producer of this type of commodity. Mined profitably for the first time in 1911, the Cuyuna Range never attained the importance of the Mesabi or held the prestige of being the first range as did the Vermilion. Located almost 100 miles southwest of the Mesabi, Cuyuna ore was different from Mesabi and Vermilion ores as the ore bodies were located deep underground, required a good deal of labor just to get to workable loads, and had to be mined by underground shaft or deep open pits. Some of the iron ore was hard rock like on the

${ }^{31}$ Ibid. 
Vermilion and some was soft like the Mesabi's. The Cuyuna also had two iron ore ranges, the North Range and the South Range, separated by around four miles, yet within the larger mining district's boundaries. Due to the Cuyuna's rather late discovery of ore bodies, municipal areas never grew to the size of those on the Mesabi. The Cuyuna Range's largest urban area was Crosby, which peaked at 3,500 people in 1920. Ironton was the next most populous municipal area with over 1,000 residents, but the rest of the Cuyuna's urban areas, Trommald, Riverton, and Manganese, struggled to reach and sustain populations of over $500 .^{32}$

Perhaps the most unique aspect of the Iron Ranges' physical landscape was that it was almost entirely altered by humans. There were few other areas in Minnesota, the United States, or the world where humans had such a massive hand in the development of their surroundings. From the cutting of vast stands of trees, to the building of city and village streets, to the digging of massive pits diving hundreds of feet below the Earth's natural surface, to the piling of mountains of overburden from stripping operations and waste material hundreds of feet into the air-the Iron Ranges were an industrially sculpted landscape. It was a landscape dependent on raw power for its survival, but not independent of men and machines to bring the fruits of labor, raw iron ore, to outside markets. The Ranges needed an outlet for their iron ore and luckily Duluth and Superior (and to a lesser extent Two Harbors), and their convenient water connections to the world, were just some seventy steel-railed miles from the pits, piles, and underground shafts of the Mesabi, Vermilion, and Cuyuna Ranges.

${ }^{32}$ Ibid. 
The links between the Iron Range's hinterland and Duluth were of course physical, as lengthy, steel lines of railroad tracks breeched the vast wilderness, but there were intangible connections as well. The transportation corridor created by the steel wheels of passenger trains that connected the hinterland to the northland's largest metropolis were traversed back and forth by thousands of people as the mines boomed and sometimes busted. One such traveler, Polly Bullard, who was hired to teach at Eveleth's Fayal Mine School, commented on a November 12, 1908, train trip to Eveleth, "the ride up here was most interesting. The types of people, the configuration of the land, and the arrangement and general appearance of the towns all along the way are entirely different from anything I had seen before." She continued:

At Duluth the train ran for some time along the lakeshore, and the view was truly wonderful. The sun was rising as we pulled out, and shone through the lake mist and glanced back from the water like a painting of [British landscape painter Joseph Mallord William] Turner. Away out, apparently rising right out of the water, were great high cranes and derricks and a revolving bridge, and up from the shore ran miles and miles of elevated track with hundreds of little ore cars standing on them. ${ }^{33}$

Though distanced some seventy or so miles from the Iron Range and physically cut off from the sprawling boom and bust Range cities, Duluth was the beginning or the end of Minnesota's Iron Ranges. It was a metropolitan heart to the Ranges' hinterlands,

\footnotetext{
${ }^{33}$ Polly Bullard, "Personal Correspondence," quoted from an excerpt from a letter in Peg Meier, Bring Warm Clothes: Letters and Photos from Minnesota's Past, (Minneapolis, Minn.: Star and Tribune Company, 1981), 204.
} 
receiving the red ore from the bowels of the Earth, while pumping the people and supplies to the Range's isolated, waiting, and wanting communities.

\section{Social Landscapes: Communities on the Ranges}

There were two basic living spaces on the Iron Ranges' proper. Mineworkers and their families, if they had them, could live on company property in corporately regulated housing, or they could live off company property in one of the Ranges' municipal areas. While most municipalities were off company property, there was one well-known company owned town, Coleraine, which was designed and administered by the Oliver for its Canisteo District employees. Most of the Ranges' urban areas were off company property and "towns" such as Hibbing, Virginia, Chisholm, Mountain Iron, Biwabik, and Aurora, to a name a few, were less corporately regulated municipal centers. One such municipality was Eveleth. Describing Eveleth's landscape, teacher Polly Bullard wrote in the early $20^{\text {th }}$ century, "from one window of the school we can look nine miles away. I have never seen such a sweep of sky anywhere excepting mid-ocean, and ever since I have been here it has been filled with great gray and silver snow clouds rolling and sweeping along. The town itself struggles over the hills. Most of the houses are little yellow and blue things but there are some very comfortable residences." 34

As Eveleth was off company property, it offered a less controlled and structured social milieu. Polly's landlady exercised the full expression of this limited freedom as the schoolteacher remarked, "Mrs. Samuelson [the landlady] is a strange creature. Her Finnish name is Mikki Koukkari. She is a rabid Socialist and all the Socialists who come

${ }^{34}$ Polly Bullard, “Personal Correspondence,” 1981, 204. 
here to speak stay at her house. One came Saturday night and they had a grand to-do down in the kitchen till two in the morning. Socialism is rampant here among the miners." ${ }^{35}$ But the power of the mining companies and their antithetical attitudes toward labor unions and political parties that were critical of corporate control was never fully extinguished. Mining company managers were able to exert control and power on the Ranges' municipalities by sitting on local governments, school boards, or charity organizations. Mining company officials also often ran candidates in local elections who were friendly to the interests of the iron ore industry and thus enjoyed a great deal of influence on local economies. Despite Polly's bucolic and free-wheeling depiction of Eveleth and its political scene, the Ranges' towns and cities were not always so hospitable to workers and alternative politics, but they were much better than the tightly controlled and sometimes dingy company-owned mining camps.

Outside of municipalities, the only other option for living on the Ranges were company locations. Underground mineworkers often lived in balloon-framed houses, or workers' cabins, of varying degrees of quality depending on work status, country immigrated from, or social affiliation. Men working as semi-skilled and unskilled laborers in the open pit mines had it much worse and lived in "camps," which were, in most cases, crudely constructed wood framed and sawn-timber shanties. In the Mountain Iron District in July 1908, these camps consisted of over thirty-four rudimentary dwellings at the Mountain Iron, Higgins, Virginia, and Stephens Mines. Twenty-two of the camps held thirty men each in a twenty-two by thirty-eight foot square space; eight

${ }^{35}$ Ibid. 
camps were twenty-two by fifty square feet and held forty-five men each; and there were only four camps for mineworkers with spouses, which were comparatively spacious for just two people at twelve by fourteen feet. Camps came furnished with "one heater, one cooking range, cooking utensils." All camps were outfitted with the above except the wife and husband shacks. Bunks, without bedding, were also found in the almost primitive residences. Living arrangements, or roommates, were determined by the company as "the customary gangs or crews are assigned to camps by the Superintendent."36

According to Sam Swanson, who was an open pit mineworker in the Hibbing area, one of the main tasks when living in the camps was keeping warm. He recalled, "the fellows who worked as laborers didn't have very good homes. In fact, they were badly built and, unless you were able to steal coal from the locomotives of the company as they went by, you probably had a very cold house. None of them had indoor plumbing and some actually had to walk to the hydrant to get water for cooking." ${ }^{37}$ Thankfully, there was no rental charge for living in the camps except that men were charged for fuel and bedding used.

In some cases immigrants were lured to mines with promises regarding housing and living conditions that the companies had no intention of keeping. Unscrupulous labor recruiters, oftentimes paid by the number of heads shipped, guaranteed items that the

\footnotetext{
${ }^{36}$ M.S. Hawkings to Mr. Pentecost Mitchell, General Manager OIMC, Duluth, n.d., "Living Conditions 2, 1908-1919,” James S. Steel Collection, Minnesota Historical Society, St. Paul, Minnesota, Box 1, Folder 140.

${ }^{37}$ Sam Swanson, "Organizing the Steel Workers Union on the Range," speech at the Virginia (Minnesota) Teachers' Institute, September 14, 1968, Sam Swanson Collection, Minnesota Historical Society, St. Paul, Minnesota.
} 
mining companies had no intention of providing for workers. An October 27, 1906, letter from John C. Greenway to William J. Olcott, Vice President of the Oliver, recorded a walk off of men because of camp conditions and the promises of a labor recruiter, "with reference to the Hungarian Labor Gang of 23 men, sent to the Holman Mine on October $20^{\text {th }}$. These men were dissatisfied with everything upon their arrival at that point. They claim they had been promised stoves, both cooking and heating, a house to live in, blankets, mattresses and dishes for table use." Greenway noted that the company would only provide the standard house, stove, and hay for bunks. Upon seeing the conditions of the camp, the workers left for Hibbing. Greenway was less concerned that the workers left as he quipped, "I think this gang was a worthless one so far as work is concerned, but I would again suggest that Mr. Fedders, Labor Agent, be cautioned to exercise care in the promises which are made labor gangs coming to this district, ${ }^{38}$ and was more so troubled with the labor recruiter's potential liberal apportionment of camps.

Upkeep of the camps was wholly at the discretion of the mining company and sanitation in the shanty towns was similarly left to the purview of mining companies. In regards to sanitation, the Mountain Iron mining district Superintendent wrote, "the camps are kept in repair by the company. The refuse about the camps is cleaned up from time to time by providing barrels. However, when the occupants of certain camps begin throwing refuse about in a careless manner, the Company then has this cleaned up and carried away, and all of the men occupying the camps are made to pay for it by a prorated payroll deduction." That was the laissez-faire system for handling solid waste. The system of

\footnotetext{
${ }^{38}$ John C. Greenway to William J. Olcott, "Business Correspondence," October 27, 1906, James S. Steel Collection, Minnesota Historical Society, St. Paul, Minnesota, Box 2, Folder 6.
} 
sanitation for human body waste was worse: "we provide for the closets [outhouses] by digging a pit, and when this is nearly filled, we have the outhouse moved to another spot, and the pit is then filled with earth." 39

The seventy-five workers in the Biwabik district had it more miserable. They were only furnished with a table, benches, and bunks in their camps. Beds were not furnished by the company and "one man usually referred to as the 'King' has charge of the camp." As for upkeep of buildings in the Biwabik camps, William Carmichael, the mines superintendent, once wrote simply, "Not any." ${ }^{40}$ Perhaps most egregiously, a series of letters in the summer of 1908, detailed the deplorable conditions at the Oliver owned Hartley Mine. Quoting from a report on the Hartley Mine's living conditions an inspector wrote:

I called President Cole's attention to a camp in the Chisholm District, which has been under the Steel Corporation's control, since the organization of the trust; the camp was located in a mudhole, foul smelling water all about and refuse everywhere; forty men were house in a shack 28x16 (roughly estimated), which was almost devoid of ventilation. Cole knew of the camp; Admitted that conditions were 'very bad indeed,' and said that he had called the attention of the Superintendent to it sometime before." 41

The lack of running water, cramped living conditions, backyard privies, and open sewers that ran through the mining camps were a breeding ground for infectious diseases.

\footnotetext{
${ }^{39}$ Ibid.

${ }^{40}$ Ibid.

${ }^{41}$ Ibid.
} 
Seeing many of the immigrant workers as less than human, mining company managers had to remind petty bosses and mine superintendents that sanitation was, in fact, a part of the company's bottom line. One such 1908 letter read, "Please inspect the privy in the rear of Plummer's camps and each day have a layer of dry clay Earth put on same. There have been three cases of typhoid develop in these camps in the last few days and we are sure that it is either due to the water they are using or a fly epidemic." ${ }^{42}$ A March 20, 1907, letter from a doctor reminded a mine manager about a smallpox scare, "I would suggest that you keep yourself advised as to the health of the community in that vicinity, and in case smallpox continues to spread, would suggest that you instruct your trainmen to take on no passengers either at Holman stripping track junction or Town of Holman." ${ }^{43}$

Workers in the Adams Mine location were seemingly better-off and had balloonframed houses available for occupancy while working for the mining company. However, the system of housing in Adams location was clearly a class-based system of occupancy. There were thirty-six company houses for management, including clerks. According to a report, seventy-five people of "this class" lived with their families in these houses and only three of these men had family members living away from the Iron Range inside or outside the United States. For skilled employees, the housing occupancy was similar. There were fifty-four houses for this "class of worker." There were 161 married employees living with their families in these houses and only fifteen of these men had

\footnotetext{
${ }^{42}$ Oliver Iron Mining Company to W.J. Trescott, Surface Foreman, "Business Correspondence, Canisteo Mine, 1908-1918," James S. Steel Collection, Minnesota Historical Society, St. Paul, Minnesota, Box 2, Folder 6.

${ }^{43}$ Dr. N.D. Kean to Dr. W.H. Magie, "Business Correspondence, Canisteo Mine, 1908-1918," James S. Steel Collection, Minnesota Historical Society, St. Paul, Minnesota, Box 2, Folder 6.
} 
families elsewhere in the United States, while only five had families living outside the United States. ${ }^{44}$ This distribution of people in management and skilled company housing meant that families were mostly intact and relatively comfortable in regards to space in the dwellings.

Life at the Adams location was dire for the class of immigrant worker who was categorized as a semi-skilled or unskilled laborer and herded into cramped living spaces. There were only twenty-five houses available to this class of worker, yet 360 people squeezed into these twenty-five dwellings. This meant that the mostly immigrant homes in this location contained about fourteen people, on average, in each home. And, of the married employees living in these twenty-five homes, twenty had their families living elsewhere in the United States and 135 had "families outside the U.S." Meaning there were a large number of immigrant men, many single, from other countries living without their families in what were probably filled to capacity boardinghouses. In a final analysis of these Adams Mine location homes, of the 115 company houses in the location circa 1918 only twenty-six dwellings, located in the management section of homes, had running water. ${ }^{45}$

\section{Social Ills on the Mesabi Range}

With a large population of mineworkers living in cramped squalor it was perhaps not unexpected that many sought to drown their sorrows in drink and vice. Mine managers and superintendents sought to control and sometimes cater to this vice, perhaps

\footnotetext{
${ }^{44}$ M.S. Hawkings to Mr. Pentecost Mitchell, General Manager OIMC, Duluth, n.d., "Living Conditions 2, 1908-1919," James S. Steel Collection, Minnesota Historical Society, St. Paul, Minnesota, Box 1, Folder 140. ${ }^{45}$ Ibid.
} 
in an attempt to pacify the labor force. Prostitution was probably the next most numerous occupation after mineworker on the Ranges; blind pigs or illegal liquor establishments seemed to be open twenty-four hours a day; and one-armed bandits (slot machines) were common in private homes. The Ranges were wild and a little wooly, and the municipal records of area towns recorded the ins and outs, and ups and downs of social life in these raucous and ribald industrial communities.

Eveleth's municipal records indicated that the town and its vices seemingly never slept. In a 1904 "Register of Criminal Actions," people were being arrested for everything from running a "house of ill fame," to "abusive language," to "D\&D," or being drunk and disorderly. More serious problems occurred with "A\&Bs" (assault and battery) and "destroying property," and there was even one case of "murder" in November 1904. Men were most often arrested for "keeping a slot machine" violations, while women were arrested for operating or keeping a "house of ill fame." Jail cells were often full, but in one November case, Andrew Johnson, who was arrested on a "D\&D" was given a "half hour to leave town."

Two enterprising Eveleth women were charged with "keeping a house of ill fame" each month from September 1904 to June 1906. Like clockwork, each month they were fined either $\$ 50.00$ or $\$ 40.00$ and charged court costs of $\$ 3$, but they never spent any time in jail. This running "bill" was charged on the first of each month between the two ladies and the City of Eveleth. If one was prone to conspiracy theories, it would be easy to

\footnotetext{
${ }^{46}$ City of Eveleth, Municipal Court Records Ledger, "Register of Criminal Actions," September-October 1904, Iron Range Research Center, Chisholm, Minnesota, Box 16.
} 
deduce that the fines were actually hush money, that the City of Eveleth was actually sanctioning the house of ill fame, and that the fines were actually a payment to the City of Eveleth allowing the women to ply their trade. Turns out this was exactly what was happening. The June 1906 city ledger indicated that the two women were being arrested "for keeping a house of ill fame," but a line down from the official arrest record, the "offense charged" column lists "fees for watchman." That the City of Eveleth was condoning and making a profit from the endeavors of these working ladies seems blatantly obvious, but following the column at the end of the page spelled it out in no uncertain terms, "this is a portion of $\$ 65.00$ charged by city for Police Protection." 47

Criminal activity skyrocketed in the summer months and the city's ledgers provided evidence for this trend. Winter months found only one or two pages of offenses, while the summer months of June, July, and August found four and sometimes more pages of offenses. Vagrancy arrests were an especially common summertime offense and often got offenders time in jail. In one or two cases of vagrancy up to sixty days in jail. In another summer offense a man was arrested on August 3 and charged with "bastardy," but the case was later dismissed when Father Bilbau married the offender to his sweetheart on August 7. Yet another man was arrested for being a "non-licensed barber," along with two others who were arrested in the same month, August 1914, for being "non-registered pharmacists." Some summer offenders were committed to the "Poor Farm," and in a few cases, the sentence was suspended and the offender was again “ordered out of town." In one apparently very egregious case, a man who was not a

\footnotetext{
${ }^{47}$ City of Eveleth, Municipal Court Records Ledgers, "Register of Criminal Actions," September-October
} 1904 to May-June 1906, Iron Range Research Center, Chisholm, Minnesota, Box 16. 
resident of Eveleth was arrested for "begging" and "given 1 hour to leave town." Other odious solstice crimes included being an accessory to a "cow at large" and having "carnal knowledge." 48

Perhaps one of the best ways to comprehend the Ranges' multitude of ethnicities is to look at the various nationalities who were occupying the area's jail cells. In a "Register of All Persons Committed to the Lockup at Eveleth, Minn., 1909-1915," the ledger recorded the truly impressive diversity of the isolated mining boomtown. Included in the entry for each prisoner was their national origin and everyone from Austrians, Finlanders, Swede-Finns, French, Irish, Swedes, Bohemians, Montenegrans [sic], Hungarians, Germans, Hrvotksi [Croatians], Russians, Canadians, Italians, Englishmen, "Indians,” Jews, a “Chinaman,” Poles, Servians [Serbians], Scots, and Americans had been locked up in Eveleth. Town banishments mostly happened to Americans or other English speakers—immigrants served time or were "committed to City works," a type of sentencing that included hard labor. ${ }^{49}$

Drunkenness was a standard violation in the Eveleth ledgers and a common problem in Range communities. While towns and cities like Eveleth struggled to control the production and distribution of intoxicating spirits, mining companies sought to control the flow of beer into and within mining properties. Mining company managers allowed private individuals to sell alcohol in company controlled spaces. Matt Pretnor was given sanction by the Oliver to sell liquors and non-alcoholic beverages in Coleraine,

\footnotetext{
${ }^{48}$ Ibid and City of Eveleth, Municipal Records Ledger, "Register of All Persons Committed to the Lockup at Eveleth, Minn., 1909-1915," Iron Range Research Center, Chisholm, Minnesota, Box 16.

${ }^{49}$ City of Eveleth, "Register of All Persons Committed..., 1909-1915."
} 
Oliver's model company town. Pretnor was, though, apparently keeping his business open past 11.00 p.m. each night, which was determined to be too late by the Oliver. The company wrote Pretnor a letter stating that the privilege of selling alcohol to a somewhat captive audience would be pulled unless he abided by the restrictions. ${ }^{50}$ Mining companies walked a fine line as they attempted to pacify laborers with alcohol in controlled, corporate-owned spaces, while at the same time regulating the consumption and sale of alcohol so that it was not being abused.

Strikes were an especially pivotal time to control the flow of alcohol. The upheaval of the 1907 Mesabi Strike caused the Oliver to forge an alliance with large breweries to regulate the flow of alcohol onto the Ranges. "Shortly after the strike of 1907 we reached an agreement with the Brewers Association," wrote Pentecost Mitchell, Vice President of the Oliver, "whereby they consented to stop the sale of liquor at any place on our locations to which we objected, and if you will kindly notify the representatives of the different agencies in Ely that you desire the delivery of liquor to these places stopped, we believe your request will be complied with." 51

Similar to labor organization there was an anti-immigrant aspect to the regulation of alcohol. Mining companies often distinguished between "good" immigrants and "bad" immigrants based on their propensity toward drinking, labor organization, or cultural festivities. A "good Finn” went to the local temperance society's picnics on company

\footnotetext{
${ }^{50}$ Oliver Iron Mining Company, "Business Correspondences," Oliver Iron Mining Company Papers, Correspondence and Miscellaneous Papers, 1901-29, Minnesota Historical Society, St. Paul, Minnesota, Box 1, Folder "Community Morals, 1907-10, 1925."

${ }^{51}$ Pentecost Mitchell to R.R. Trezona, "Business Correspondence,” August 11, 1909, James S. Steel Collection, Minnesota Historical Society, St. Paul, Minnesota, Box 1, Folder 140.
} 
land and never missed a day of work. A "bad Finn" was a member of the local socialist organization and spent his free time at the People's Library in a labor hall reading Marx. Similarly, a "good Austrian" went to church on Sunday and took out citizenship papers, while a "bad Austrian" ran a "blind pig" or an illegal alcohol business run out of a residence. In the eyes of J.H. Hearding, an Oliver mine manager, John Capan was one such "bad Austrian." Hearding was attempting to "find if any intoxicants are being sold [in Capan's house] or disposed of in any way. If such is the case we will immediately arrest him for running a blind pig." In the eyes of mining companies, alcohol consumption seemed to be the only common denominator between the "good" and "bad" Austrians, "the sale of beer is so universal on the locations, the consumption of it is so general amongst both the good and the bad Austrians that I wish to try out the effect of shutting this beer off to see if our night watchmen cannot get along in a more peaceable manner."52

The mining companies were much more successful in regulating alcohol than the Ranges' towns and cities and the display of control and power by mining companies in monitoring and controlling the consumption and sale of alcohol was impressive. While towns had to work through the legal process in alcohol related cases, mining companies could serve up swift, autocratic consequences. In one such case a night watchman at the Spruce Location near Eveleth had a run-in with three men who were drunk and disorderly. The hired mine guard wanted to restrict the sale of alcohol to the men because according to the watchmen, "these men are Pretty good men until they get beer into their

\footnotetext{
52 J.H. Hearding to Pentecost Mitchell, "Business Correspondence," May 27, 1908, James S. Steel Collection, Minnesota Historical Society, St. Paul, Minnesota, Box 1, Folder 140.
} 
systems, when they become noisy and disorderly," and that if they did not change their drunken behavior "we will put them off the location, but I thought we would first try the practicability of stopping them beer." 53

In Capan's case, the company noted that he was probably running a blind pig and that "the house... on the extension of Adams Avenue [near Eveleth], has been very disorderly for the last few nights. Capan has but two or three boarders but there are a great many men going to get beer there." 54 The Oliver then concocted a plan to restrict the flow of alcohol into the location where Capan lived. Instead of posting more men to keep an eye on the situation, the Oliver demonstrated its power by contacting regional breweries to enact the 1907 Strike-related alcohol regulation agreement in the hopes of shutting off Capan's supply. An amazing exposition of regional clout began to unfold as the Oliver wrote Duluth brewing magnate August Fitger to ask him if he "would notify them of such [blind pig] houses," and then, if necessary, "refuse the man any beer until such time as the man obtained permission to receive same, from the mining company." 55

The Oliver went about notifying other regional breweries of the blind pig and inquiring if they had sold beer to Capan. These letters also included an edict declaring that no alcohol was to be sold to men in Capan's company location. The Oliver promptly received a letter back from August Fitger, and then another letter from the Hamms Brewing Co. in St. Paul. The letter from Hamms read, "in reply, beg to state that after

\footnotetext{
${ }^{53}$ J.H. Hearding to Pentecost Mitchell, "Business Correspondence," June 3, 1908, James S. Steel Collection, Minnesota Historical Society, St. Paul, Minnesota, Box 1, Folder 140.

${ }^{54}$ J.H. Hearding to Pentecost Mitchell, "Business Correspondence," May 20, 1908, James S. Steel Collection, Minnesota Historical Society, St. Paul, Minnesota, Box 1, Folder 140.

${ }^{55}$ Ibid.
} 
searching our records at this office we find that we have never had any business dealings with the above parties. However, we have notified our representative in that district that in case he was approached by such parties to absolutely refuse to sell them any goods until otherwise notified." August Fitger replied, "we will say that we have given strict orders to our Agent in the Eveleth district to deliver no beer whatsoever to [the location] named in your letter, and will say that we shall always be most willing to abide by your wishes in matters like the above." The Oliver got similar letters from the Blatz Brewing Co. of Milwaukee, the Gund Brewing Co. of LaCrosse, Wisconsin, the Minneapolis Brewing Co. (Golden Grain Belt Beers), the Duluth Brewing \& Malting Co, "the Monarch of all Pure Malt Beers," the Virginia Brewing Co., and the Schlitz Brewing Co. of Milwaukee. ${ }^{56}$

The strict and well-orchestrated monitoring and regulation of alcohol went on unabated in mining company locations. "Beer is still delivered in small quantities to the boarding houses [at Fayal location near Eveleth], but as far as we know we have no 'blind pigs.' Our policemen watch the delivery of it and if we think any place is getting more than necessary for the number of boarders, we notify the party to move off the location, and if employed at the mine he is discharged. In this way we have had but very little trouble with 'blind pigs," wrote one Oliver mine superintendent. The Catch-22 in what could be termed Operation Alcohol Management, was that if the men did not get the sweet suds at company locations, they would head into the Ranges' municipal centers

\footnotetext{
${ }^{56}$ Oliver Iron Mining Company to Various Breweries, and Various Breweries to Oliver Iron Mining Companies, "Business Correspondences," Oliver Iron Mining Company Papers, Correspondence and Miscellaneous Papers, 1901-29, Minnesota Historical Society, St. Paul, Minnesota, Box 1, Folder "Community Morals, 1907-10, 1925."
} 
where mining companies had little control in monitoring or regulating the consumption of alcohol by its workers. The same Oliver superintendent wrote of the problem, "we are satisfied, however, that if we were to prohibit the delivery of beer to boarding houses the men would go into saloons in the village [of Eveleth], and we believe the effect would be worse than at present." 57

To rectify this situation, the Oliver sought the partnership of Eveleth's business community in general, and in specific, the Eveleth Businessmen's Association. Therefore, not only did the company have the help of many of the Upper Midwest's major breweries in regulating the consumption and sale of alcohol on its properties, it also had the help of a local businessmen's groups. A January 30, 1908, letter from the Superintendent of Eveleth's schools, on behalf of the business community in Eveleth to Thomas F. Cole of the Oliver highlighted the partnership:

As per our conversation of Saturday evening, I am writing you on the subject of your company's regulating the sale of intoxicating liquors on your mining locations. You people are the best judges of how this may be most easily done, but it seemed to the Eveleth Business Men's Association that forbidding the Brewers the locations or evicting from your houses tenants who persist in retailing beer, etc., illegally, would be sufficient. The processes of law seem slow and rather ineffective to us. We find life in mining camps not an unmixed joy. Your company has never disregarded the public's wishes. Again, may we presume to say that the labor situation is ripe for such action. In the bargain you well know

\footnotetext{
${ }^{57}$ R.R. Trezona to Pentecost Mitchell, "Business Correspondence," August 11, 1909, James S. Steel Collection, Minnesota Historical Society, St. Paul, Minnesota, Box 1, Folder 140.
} 
that drunken men are expensive on any job, and more especially a mining one.

Finally, the burden of the swarm of degenerate children will be felt by you in the future as it is now by me in the school. ${ }^{58}$

Consequently, the rather corrupt, but somewhat whimsical irony in all of this intrigue regarding social ills on the Ranges, and Eveleth in particular, had come an unethical full circle. Eveleth's local government officials, some of whom were likely in the Businessmen's Association, had accepted hush and protection money from prostitutes. Now, however, when the OIMC came calling Eveleth's businessmen suddenly found the moral high ground, deciding to work with the Oliver in curing the intolerable social ills of alcohol abuse. Worse, and with an almost unbelievable sense of hypocrisy, Eveleth's superintendent of schools had the audacity to complain about a "swarm of degenerate children" under his care morphing into degenerate workers while his community was sanctioning prostitution to bolster the city's municipal coffers. In a somewhat small boomtown industrial city, it seems unlikely that a town father such as the school's superintendent would not know of the house of ill fame in question.

While some mineworkers did in fact seek escape or happiness in the bottom of a bottle or in the arms of a "working-girl," many others sought to elevate their spiritual or social consciousness in the midst of the raucous and unruly Iron Ranges. For those men with families, getting their children an education was of utmost importance. Slovenian American Veda Ponikvard remembered that "the schools on the Iron Range began to be

\footnotetext{
${ }^{58}$ Superintendent of Eveleth Schools to Thos. F. Cole, "Personal Correspondence," January 30, 1908, Oliver Iron Mining Company Papers, Correspondence and Miscellaneous Papers, 1901-29, Minnesota Historical Society, St. Paul, Minnesota, Box 1, Folder "Community Morals, 1907-10, 1925."
} 
built at a very early time. For example the [mine] locations surrounding Chisholm had small wooden schools." ${ }^{59}$ Though the small, impermanent schools of mining locations could be swallowed and lost to expanding pit mines, large schools in the Ranges' municipal centers attained a sense of permanence. The schools became home to the Ranges' vibrant multi-ethnic culture, and also mirrored the somewhat rough exterior of life in an isolated industrial region. Polly Bullard, a schoolteacher from a middle-class family in the Minneapolis-St. Paul area, commented on her experiences in an early $20^{\text {th }}$ century Iron Range classroom, "as to school, I have a funny little room, with the leavings of several rooms in it—quite a handful therefore. They are Italian, Austrian, Finnish, Swedish and Irish—only one American, I believe, and some of them have only been in this country a year or so. Most of them are good children, but I have two or three in need of a good deal of squelching." 60

Churches and organized religion were another such place where mineworkers turned to for uplifting interactions. Generally, mining companies were supportive of religious life on the Ranges as ministers and priests advocated sober and industrious lifestyles. For many with families, churches were the only place where salvation and sobriety could be expressed. The spires of Italian, Croatian, and Slovenian Roman Catholic churches dotted the Iron Ranges' landscape, while Finnish Lutheran houses of worship occupied the same streets. Along with spiritual enterprises, laboring men and their families also began founding materially-influenced organizations to fill their bellies

\footnotetext{
${ }^{59}$ Veda Ponikvard, “Oral History: Minnesota Radicalism Project,” interview conducted by Carl Ross, Minnesota Historical Society, St. Paul, Minnesota, May 13, 1988.

${ }^{60}$ Polly Bullard, "Personal Correspondence," 1981, 204.
} 
and minds. The Croatian Fraternal Union of America, headquartered in Pittsburgh, Pennsylvania, had several branches on the Ranges, and Slovenian National Homes in cities such as Ely and Chisholm provided immigrants with a chance to engage in debating, participate in a theatrical productions, or host weddings and other rituals. For many single immigrant Finnish men, poikatalos, or boarding houses, were a first contact with collective action. In these houses mineworkers lived communally sharing resources, reading ideological tracts, and discussing labor and social conditions. While these organizations and places were a type of mutually funded, class-conscious undertaking, there were no overt forms of union or political organization. ${ }^{61}$

Many in the Ranges' temperance societies, and especially in the Finnish immigrant temperance societies, were unwilling to accept spiritual answers to what they saw as material problems. Fred Torma was one such person. A Finnish immigrant from an agricultural background, Torma immigrated to the United States in the early $20^{\text {th }}$ century. He had been exposed to socialist thought while in Finland, but was unfamiliar with industrial work. Once in the United States, he began working in the Mesabi Range mines and quickly developed an oppositional attitude toward the exploitation he saw around him. Wanting to find an outlet from the doldrums of industrial life while escaping the ubiquitous saloon scene, Fred joined with his fellow countrypersons and began to organize. The goal was to organize a socialist group, but the route to achieving such an

${ }^{61}$ Dragosich Family Papers, Various Folders on the Croatian Fraternal Union of America, Iron Range Research Center, Chisholm, Minnesota, Matjaz Klemencic, "Slovene Settlements in the United States of America," accessed at, http://www.theslovenian.com/articles/klemencic4.htm, October 30, 2014, and for a discussion of Finnish immigrant boarding houses see Gary Kaunonen, Finns in Michigan, "Discovering the People of Michigan Series," East Lansing, Mich.: Michigan State University Press, 2009, and Gary Kaunonen, Challenge Accepted: A Finnish Immigrant Response to Industrial America, Lansing, Mich.: Michigan State University Press, 2010. 
organization, and the procuring of a coveted social hall, went through a Christian temperance organization:

there were temperance halls in almost every town. At first we tried to take over these temperance halls for socialist uses. The first place was at Stevenson Mine-a temperance hall. I joined that temperance league. At that time the Finns were very much enslaved by liquor. When the boss went for his morning drink the working men followed. I began organizing work to get members into that temperance league [to then vote the temperance society into a socialist local]. ${ }^{62}$

The major obstacle in Torma's plan was not converting members, as many were receptive to socialist principles of co-operative economic action, working-class expressions of culture, and sobriety. Instead, the difficulty rested in the hall being located on company land in Stephenson Location north of Keewatin, "we tried to take over that hall then so that we could also take up working people matters, but the mining company intervened. They sent representatives to say that they had provided the money and materials for the hall and it would not be used for any labor movement purposes."63

Much like temperance societies and religious groups, socialists sought to identify, explain, and change social ills. The primary difference was that socialist groups provided a material explanation for the problems that plagued life on the Ranges. This explanation, often from a Marxist, class-based perspective, explained the roots of socioeconomic problems on the Ranges. Early workingpersons' societies were looking to cure social ills,

\footnotetext{
${ }^{62}$ Fred Torma, "Oral History Interview," Oral History Collection, Finnish American Historical Archive, Hancock, Michigan, 26-27.

${ }^{63}$ Ibid.
} 
while simultaneously addressing the dangerous and deadly working conditions in the areas pit and underground mines. Thus, while municipalities, mining locations, and the men who ran them allowed prostitution and the sales of alcohol to pacify labor, they frowned upon and actively sought to stomp out the influence of class-conscious worker's groups and organized labor. Nevertheless, it was the dangerous and deadly working conditions that necessitated such working-class advocates. 


\section{Chapter 2: Labor, Strikes, and Progressives}

\section{Chapter Introduction: Organized Labor and the Economic Landscape}

As political and social organizations began to contemplate the social ills of the Iron Ranges, working conditions and the inequitable distribution of wealth became parallel concerns. Labor unions began to emerge in the late $19^{\text {th }}$ and early $20^{\text {th }}$ centuries on the Ranges, and began to openly address questions that immigrant laborers talked about in private. Immigrant political and social organizations soon were combining social questions with grievances about conditions in area mines. This led to the formation of a growing sense of class-consciousness among the immigrant mineworkers. Revolts against labor conditions followed.

Many involved in the immigrant organizations read about, advocated, and clamored for a revolutionary change to such social and working conditions. This perspective deeply troubled area mine managers and repressive actions were taken to ensure that the "bug" of socialism and unionism was controlled and monitored, if not eradicated, from immigrant working populations. This growing tension existed between immigrant workers and mine management in the early $20^{\text {th }}$ century, leading to several intense, but truncated labor actions. Immigrants were not the only people who noticed such problems. Middle-class reformers on the Ranges noticed the same social and workplace inequalities, but espoused a different, more moderate course of action. Progressives, as they were termed at the time, advocated a political campaign to gradually identify and change the social and workplace ills of the Ranges. Like immigrant labor and socialist organizations, Progressives saw the inherent contradictions of capitalist production-accumulation of wealth by the few to the detriment and 
exploitation of the many - as the root of social and workplace discontentment. Unlike radical immigrant unions and political organizations, Progressives did not advocate revolutionary aims in addressing these social and workplace ills. This discrepancy between Progressives, most of whom were fully enfranchised, and immigrant workers who did not have access to a political voice, is the focus of this chapter.

\section{Working Conditions on the Ranges}

Work and the Iron Ranges' labor force can only be understood in connection with the region's other industries because working in northern Minnesota's mines was a boom and bust, seasonally structured occupation. In the late $19^{\text {th }}$ and early $20^{\text {th }}$ centuries, most of the labor force on the Ranges were itinerant workers. Mining companies did employ family men over extended periods of time, but largely the work force was comprised of young men who were laid off in the winter and subject to the whims of fluctuating iron ore prices. When the price of ore fell, a mineworker was fired or laid off; when the price was up or ore stockpiles were deleted, there were jobs aplenty. When work was thin, posthumous mineworkers headed by foot into the massive forests of northern Minnesota and Canada, to family farms on the industrial periphery, or to the flowing wheat fields of the Dakotas. And, perhaps some in the search for work also wandered to other mining districts in Michigan or Montana. The sporadic employment of northern Minnesota's iron mines led to an army of job seekers seasonally wandering the northern climes of the Midwest in a triangular job-seeking route.

Evidence of this triangular job-seeking pattern comes from Sam Swanson's time as a laborer in the Upper Midwest. Swanson, who was born in Chicago, moved to Clearwater County, Minnesota, at the age of seven after his mother died. Moving in with 
his uncle, and expected to earn his keep on the farm, Swanson worked on his uncle's homestead until the age of fifteen when his uncle became disabled. Sam was forced to strike out on his own. He headed for the wheat fields of northwestern Minnesota and northeastern North Dakota. Hired on for a dollar a day plus board, the work was consistent, if not for a few days when a rainy spell would halt the harvest. According to Swanson, the food served for meals was good and there was plenty of it, except during rainy spells when the farmer refused to feed the idled workers. Remembering these times and his healthy appetite, Swason recalled, "[the farmer] would take me into town and I would have to stay there and pay for my hotel and restaurant until the fields dried up sufficiently so I could go back to work." ${ }^{64}$

Work in the wheat fields was migratory. "I will say though that I stopped in the Red River Valley...after we had finished the harvest in the Red River Valley, I drifted westward where the grain ripened later and, of course, the wages were 50c a day higher," Swanson remarked. His travels west took him to Minot, North Dakota, where he met a group of workers who had organized themselves into a "hobo jungle" that was partial to the revolutionary industrial unionism of the IWW. Swanson recalled of the hobo jungle that he joined, "a lot of the men that worked the wheat fields were known as bums, tramps, hobos, and farmer boys looking for a few dollars. I went down to one of these jungles to look it over...there were about 20 or 30 fellows sitting around. They didn't seem to mind my coming and looking at their group. In fact they offered me a cup of

${ }^{64}$ Swanson, "Organizing the Steel Workers Union on the Range," September 14, 1968. 
their bouja and mulligan or whatever you call it. After looking it over I decided I wasn't that hungry.",65

After being run out of the jungle when a few local farmers noticed there were chickens missing from farms that were being found in the bottom of hobo stews, Sam and his new found friends were escorted out of town and loaded onto boxcars headed for points west by armed sheriffs and their deputies. After his trip in the boxcar was over, Sam helped a farmer finish his year's threshing and then returned to Minot where he attended his first IWW meeting, "I had to join the union. It cost $\$ 1.00$ in initiation fees and 50c for a stamp or my first month's dues." Sam's initial IWW meeting consisted of listening to the complaints of overworked and underpaid harvest workers, but after the grievances had been registered the union meeting broke into song. And the Wobblies, known as the singing union, filled Minot's nighttime skies with more than a few songs. Recalling the meeting, Swanson remembered that, "it was the first time I had ever heard 'Solidarity Forever.'” Commenting on the hoboes' harmonizing Swanson recollected that, "what our singing lacked in quality, I think we made up in quantity. We really were a loud group, considering the number that attended the meeting." 66

Swanson's itinerant lifestyle was an example of the Wobbly's unique, roaming culture. The proletarian hobo's lifestyle was a celebrated aspect of the union's mobility and portable organizing methods. As an industrial worker on the move, Swanson's life was the stuff of IWW legend; a legend that had been recorded and praised in a song titled “The Mysteries of a Hobo's Life":

${ }^{65}$ Ibid.

${ }^{66} \mathrm{Ibid}$. 
I grabbed a hold of an old freight train

An' around the country traveled,

The mysteries of a hobo's life

To me was soon unraveled.

I traveled east and I traveled west

And the "shacks" could never find me,

Next morning I was miles away

From the job I left behind me.

I ran across a bunch of "stiffs"

Who were known as Industrial Workers,

They taught me how to be a man-

And how to fight the shirkers.

I kicked right in and joined the bunch

And now in the ranks you'll find me,

Hurrah for the cause-To hell with the boss!

And the job I left behind me. ${ }^{67}$

Leaving his job in Minot, Sam went back home for a short respite and then left for northern Minnesota's large tracts of pine forests. In Bemidji, he came into contact with what the Wobblies would call a "labor shark," a person who sold jobs, and then resold jobs when loggers were purposefully fired so they had to buy back their former jobs. After paying an employment agent $\$ 2.00$ for a job, Sam caught on as a bull cook in a

${ }^{67}$ Unknown songwriter, "The Mysteries of a Hobo's Life," in I.W.W. Songs to Fan the Flames of Discontent, Joe Hill Memorial Edition, Cleveland, Ohio: I.W.W. Publishing Bureau, n.d. 
logging camp. A bull cook fed the fires of the camp's stoves and the job had little prestige and even less in wages, but it was good enough for Sam, who was sixteen at the time. In time he became a skidder helping to ferry cut timber out of the woods before spring break up. In one especially wet spring Sam and the logging crew were, "wet clear up to the arm pits, and walking home at night our clothes would freeze. I decided that this was not the life for me and I quit." However, Swanson found his way into the woods again, and the cycle between fields and woods continued until one season when Swanson went to work in the mines of Hibbing. ${ }^{68}$

Working for the Oliver, Swanson became a pitman in an area open pit mine. His insights about work in the open pits of the Mesabi Range give a technical understanding of work life, "Now, a pitman is the man, or the group of men, who work around a steam shovel. The steam shovel operator was the boss. He had an engineer up in the boom, called a craner. A fireman kept up the steam. There were from four to six pitmen, depending on the bank [of ground] that you had," and "there was a flunky who carried water and did other jobs...while the 'walker,' was the superintendent of the pit." Working with the pit crew was a new experience for Swanson and being one of the only people who could speak English was difficult, "I was put to work with three other fellows, who didn't know very much English. They were pretty good at swearing, but outside of that they hadn't learned many English words. ${ }^{\text {69 }}$

Working in the pits was very labor intensive and Swanson estimated that "of the men who worked in the mine at that time, about eighty percent were classified as

\footnotetext{
${ }^{68}$ Swanson, "Organizing the Steel Workers Union on the Range," September 14, 1968. ${ }^{69}$ Ibid.
} 
[unskilled] laborers." Mining in the pits had been deskilled as machinery and mechanized production replaced back breaking work. This of course meant that low paying jobs in the pits were easy to get, but hard to keep. Bosses were paid more, but still not the wages of skilled machinists or surface crews. In the case of the men who maintained the tracks used to move the huge steam shovels there was "a boss and everybody else was labor," and "the people who put in the pipes and pumps were called the pipe gang. They had one pipeman and the rest of them were labor." Similarly "up on the dump, where they unloaded the stripping [layers of dirt covering the ore known as overburden] and took care of the waste, they had a dump boss and, of course, everybody else was labor."70

This was the rhythm of a Minnesota iron ore mine: the clank, moan, and whirs of huge steam shovels as they swallowed mouthfuls of earth, the thousand-pound thud of debris dumped into railcars, and the steel clang as these railcars hauled materials up, around narrow gauge railroads, and out of the pit. It was an industrial tune that Sam Swanson grew to know well each season, until "every fall [when] I would get laid off. At the end of the ore shipping season not much work was done in the open pits...the work was done in the summer months and when the ore shipping season was over the company would lay off the men." ${ }^{71}$ And then it was back into the far-stretching harvest fields in the fall, followed by a trip into the freezing woods of northern Minnesota, only to wait for the opening of ore shipping season.

While many men headed to the harvest fields and woods after being laid off, some stayed on the Ranges, eking out a living on the summer's wages. While being

\footnotetext{
${ }^{70}$ Ibid.

${ }^{71}$ Ibid.
} 
unemployed over the winter was likely difficult, it was better than working on a skeleton crew in the open pits during the bone-chilling Minnesota winter. One mining captain wrote of the harrowing weather situation in the late $19^{\text {th }}$ century, "How can men do a day's work with the thermometer at 45-50 below zero? We have not had but two days above zero since winter started. One day this week 76 men were off-if it were summertime these men would have made full time." ${ }^{72}$ Thus, the weather of Minnesota's North County was a safety hazard in its own right for open pit mineworkers: blazing hot and mosquito infested in the summers and damnable cold in the winters.

Underground mines provided steadier year round employment, but were more dangerous. Beholding to the whims of financial market fluctuations, underground mining was all about labor intensive human production and speed-ups and cost cutting measures endangered the lives of the Ranges' underground workforce. All the elements for dangerous job conditions existed in the underground mines. Mineworkers would travel hundreds of feet underground into a shaft and then would begin work either extending drifts (horizontal tunnels) to work areas or drilling in cave-like hollowed out areas to set up a "blast pattern." Miners, or skilled underground workers, drilled blasting holes, packed the holes with a blasting agent, and then exploded the hard rock. Another set of workers, who were unskilled laborers, would then load the exploded material into a car and ferry the loaded cars to the shaft to be pulled to the surface. There were many opportunities for disaster in underground mines.

\footnotetext{
${ }^{72}$ E.M. to G.C.S., "Labor: Working Conditions, 1885-1928," February 10, 1885, James S. Steel Collection, Minnesota Historical Society, St. Paul, Minnesota, Box 1, Folder 50.
} 
The Iron Ranges' largest loss of life occurred in an underground mine, the Milford, on the Cuyuna Range. On February 5, 1924, forty-one mineworkers died when water from Foley Lake spilled into the mine after the mine's surface began to cave-in. A warm rush of air preceded the gushing waters and as the mine's forty-eight person day shift attempted to scramble to the only exit shaft, the water overtook mineworkers one by one. The mine's skip car, the conveyance to get people (and ore) up the shaft, was on the surface and the men were forced to attempt to climb to safety. Only seven made it out of the mine alive. It took over a year to de-water the mine and during that year long process bodies were recovered as well. ${ }^{73}$

Many immigrants coming from southeastern European countries where agricultural work was the standard means of making a living were shocked and appalled by the working conditions in both pit and underground mines. The daily, deadly serious working conditions in the mines were psychologically grueling. As illustrated by the Milford Mine Disaster, underground mines were dangerous and workers in the open pit mines were just as susceptible to death and injury. In one instance recorded in a June 8, 1908, company letter, two immigrant mineworkers were killed in the Holman open pit mine, "yesterday at 12.10 noon, two Italians were killed by an accidental explosion of dynamite. They were both 'gopher hole' contractors. ${ }^{74}$ The evidence now at hand would indicate that they were preparing to fire a small 'pop' in the breast of their 'gopher hole'

\footnotetext{
${ }^{73}$ Lamppa, Minnesota's Iron Country, 193-195.

${ }^{74}$ As the Mesabi open pit mines went deeper, the soft ore became more consolidated so that it was difficult to scoop the ore out with steam shovels. Gopher holers would use pick axes and shovels to tunnel into the side of an ore deposit, and then used a blasting agent to loosen the material so that it was easier to scoop. Lamppa, Minnesota's Iron Country, 184.
} 
and probably accidentally exploded the cap, which set off several sticks of dynamite."

The accident was a particularly gruesome one, "the bodies were frightfully mutilated and dismembered. There were three other 'gopher hole' men within 150 feet of them. Their attention was directed to the matter by the explosion and seeing the bodies hurled in the air." In almost every such case of death, mining companies found fault with the men working in their employ. Predictably, mine manager John C. Greenway was less concerned with the mineworkers' deaths and more concerned with the bottom line, "[the coroner] ruled that these men met their deaths by an accidental discharge of dynamite, the cause of which is unknown, and that no one was to blame other than themselves."75

Similarly, a mining company sought to cast-off blame in 1913 when they fought a lawsuit that demonstrated the dangers of mining were not confined to the area's open pits. According to a personal injury complaint originally lodged in a St. Louis County court, a twenty year old immigrant woman who was visiting a Hanna Mine boarding house was struck by falling debris from the Brunt Mine while walking on a public highway. She was knocked unconscious and had to be taken to the hospital. She sued two mining companies for over $\$ 30,000$, but the judge dismissed the case against one company while ruling in her favor for $\$ 7,000$ against the Brunt Mine's owners. Apparently believing that even bystanders walking on public highways were part of collateral damage in the making of profits, the Brunt Mine managers fought the woman's legal case all the way to Minnesota's Supreme Court. For the mining company the problem was not in paying the $\$ 7,000$; rather, it was that they did not want to set a

\footnotetext{
${ }^{75}$ John C. Greenway to Oliver Mining Company Labor Agent, "Business Correspondence," June 8, 1908, James S. Steel Collection, Minnesota Historical Society, St. Paul, Minnesota, Box 2, Folder 6.
} 
precedent in being found at fault for an injury in or around the mine. According to a report on the incident and subsequent lawsuit, lawyers for the mining companies argued that "if the plaintiff was injured as a result of the defendants' blasting operations, the same was the result of her own negligence and disregard of warnings and knowledge on her part that she was in a place where she was likely to be struck by material from the blasting operations in such mine, and that she voluntarily assumed the risk of such danger." And, to add insult to injury, the mining company responsible for injuring the girl was eventually found not guilty because no one could irrefutably prove that the debris that struck the woman was from the Brunt Mine—-though the Brunt was the only mine blasting in the immediate area. ${ }^{76}$ Not even the public streets on the Ranges were safe. Manipulating the work force—and the general public— to avoid liability, ensure profits, suppress wages, and pit ethnicities against one another was a common tactic in controlling the mines' mostly immigrant employees. Keeping surplus pools of laborers was a way to keep the workforce from striking as not enough jobs and too many people frustrated attempts to organize workers. As one letter written in the spring of 1907, just before a large strike commenced on the Mesabi, indicated, "I note your intention to commence importing common labor to the Range at once with an idea of maintaining a large floating labor supply with an idea of relieving the tension of the usual situation which arises in the Spring." Communications between management regarding laborers reflected the harsh attitudes of mine managers regarding immigrant employees: they were not individual people, but rather a group commodity to be bought and sold, used and

\footnotetext{
${ }^{76}$ Henry Burleigh Wenzell, Cases Argued and Determined in the Supreme Court of Minnesota, Minnesota Reports Vol. 23, St. Paul, Minn.: Lawyers Co-operative Publishing Co., 1913, 130-133.
} 
discarded. There was seemingly little difference in the way managers physically ranked their purchases of wage slaves from how chattel slave owners assessed their acquisitions in the American ante-bellum south, "just at the present time we are not in shape to take any more [men] at the Holman Mine but can take two gangs of twenty-five men each at the Canisteo Mine. Would prefer Northern Italian, Bulgarian, or Austrian in the order named." 77

While immigrant workers were preferred for the physically demanding work, often work that native American workers refused to do in the mines, the expectation was that they would become assimilated to American social values and a Protestant work ethic. As Greenway commented on promotions, "I would also be in favor of making it clear to our men that when we make promotions, either from common labor to foremanship, or increases in the pay of foremen, that, other things being equal, that the man with full citizenship has a better chance for promotion and will be favored over the one without citizenship." 78 The immigrant mineworkers were good enough to produce, toil, and die in the mines, but if they were not willing to become true assimilated Americans, they were not good enough to receive a promotion for their efforts. The socioeconomic place of an immigrant, no matter his work ethic or meritorious service, was fixed and controlled by the mining companies. And, even when workers were set to get a conciliatory gesture, it came with strings tightly affixed to maintaining the

\footnotetext{
${ }^{77}$ John C. Greenway to Oliver Mining Company Labor Agent, "Business Correspondence," March 11, 1907, James S. Steel Collection, Minnesota Historical Society, St. Paul, Minnesota, Box 2, Folder 6. ${ }^{78}$ John C. Greenway to George W. Morgan, "Business Correspondence," May 22, 1916, Oliver Iron Mining Company Papers, Correspondence and Miscellaneous Papers, 1901-29, Box 1.
} 
companies' bottom lines as was the case in testing an eight hour work day for mineworkers on the Vermilion Range.

In March of 1912, a number of mines switched to eight hours shifts as a test to determine if the new-fangled work day would be productive in Oliver mines. Mine managers wrote in glowing terms regarding the eight hour day and rejoiced that even the tonnages of ore were the same or improving. However, while they believed things were going well with the eight hour day the opposite seemed to be true for workers. Joseph Mantel, a chairman for an underground workers committee in Ely, wrote to the Oliver on March 18, 1912, “A meeting was held here in this City, last Sunday March 17, in presence of about one hundred underground miners," in which we discussed the eight hour day and an article in the Ely newspaper that read, "Vermilion Range likes new system. Eight hours for underground miners gives much satisfaction."79

Mantel and his one hundred or so fellow workers disagreed. On the contrary, these workers argued that as practiced the eight hour shift was robbing workers of welldeserved break time. Getting ready to go underground for work commenced at 7.30 a.m. as mineworkers had to be on deck ready to go underground a half-an-hour before their shift. Arriving in their underground work areas at 8 sharp, all that workers heard from start of shift to noon was "dig in, dig in." At 12.10 p.m., when mineworkers were supposed to be hoisted to the surface and on their way to eat lunch in the company dryhouse, or break room, the ore skip was still hoisting ore to the surface. The first cage of workers was not hoisted to the surface until 12.15 and the hoisting of workers

\footnotetext{
${ }^{79}$ Joseph Mantel to W.H. Johnston, "Personal Correspondence," March 18, 1912, James S. Steel Papers, Minnesota Historical Society, Box 1.
} 
continued until 12.30. This was also the time when the supervisors began to call, "All aboard for the first cage to go into the mine." Men had to be in their respective places of work at 1.00 p.m. sharp. As Mantel noted, "now how much time have the men for their dinner if any? Not figuring any rest at all." Further ruining the mineworkers' lunch, Mantel wrote that shift bosses walked up and down the dryhouse showing "the men how to eat quick and to put the lunch down into their stomach fast, if [the mineworker] doesn't obey he is taken by the arm and pushed out of the dry house and told to go home if he doesn't want to work." 80

Mantel and the group of mineworkers he spoke for then respectfully petitioned the Oliver to "use the miners more liberally in the future than at present time and furthermore, to allow the said miners a reasonable time for their lunch time between working hours." ${ }^{81}$ For attempting to communicate with the Oliver in this penitent manner, Mantel seems to have been "dispensed with," as a March 25, 1912, letter from W.H. Johnston, General Superintendent of OIMC indicated, "the change [to an eight hour day] has given very general satisfaction at all our mines. We have had only one complaint and that was at our Queen Mine by a chronic kicker who seemed to think they had too little time at noon. His services have been dispensed with.” Johnston then went on to opine that "just as soon as we commence listening to suggestions-either on the part of the men or of outsiders - there is no telling where the trouble will end." 82

\footnotetext{
80 Ibid.

${ }^{81}$ Ibid.

82 W.H. Johnston to Oliver Iron Mining Company, "Business Correspondence,” March 25, 1912, James S. Steel Papers, Minnesota Historical Society, St. Paul, Minnesota, Box 1.
} 
Additionally, the remuneration for a shorter work day was brought up in regards to the institution of the eight hour day. Of course mining companies expected the men to do ten hours of work during the eight hour shift—and be paid the same contract prices for delivering more tonnage. Johnston remarked regarding wages and the eight hour day:

There is a feeling among the men, however, that on account of the fewer hours of work it will necessitate an increase in the rates per car or foot, to make wages equal to those now prevailing. In this matter, I wish to state we have made it very plain to the men that there is to be no increase in contract prices, and all miners are expected to do as much or more in the eight hours than they formerly did in the ten. The men, I believe, are doing better work per hour than they formerly did, and when they find no increase will be made on their contract prices, they will see that they equal their former earnings. ${ }^{83}$

With men like Johnston at the helm of the Iron Ranges' mines it became clear to the workers of the Iron Ranges that if they were going to have a voice in the conditions of their labor, it would not come without a fight.

\section{Early Labor Organization on the Ranges}

As this dissertation has established, work life on the Ranges was extremely difficult. More difficult was the struggle of mineworkers to gain a voice, or small increments of control in the conditions of their labor. Certain occupations of skilled labor in the Ranges' mines were organized by craft or trades unions, but immigrant labor, mostly unskilled and working the mines' most dangerous jobs, were not allowed union

\footnotetext{
${ }^{83}$ W.H. Johnston to Oliver Iron Mining Company, "Business Correspondence," March 19, 1912, James S.
} Steel Papers, Minnesota Historical Society, St. Paul, Minnesota, Box 1. 
representation. In many cases union representation was violently withheld from these workers. From his experiences in labor organization, Sam Swanson concluded that "in the past, the mining companies had their men in various political offices and had exerted a strong influence on the community, not only as the principle employer of labor, but politically and socially and by having many of the business men on their side." 84

Swanson continued:

Fear of company reprisals on the workers was a barrier to organization. Many miners occupied company homes, while others had built homes on company property. To be fired by the company meant being cast out, for, when one got in bad with the company, it was hard to get a job anywhere else in town. The record showed that many of the men who participated in the union organization in previous years had been let go [blacklisted] and had had it tough going since that time. Some of these men were unable to get jobs with the mining company when the applied for work. ${ }^{85}$

Despite the concerns and pitfalls of labor organization, the agonizing working conditions and the exploitation of immigrant workers spurred efforts to organize those deemed to be unorganizable by the conservative, often anti-immigrant American Federation of Labor (AFL). That there were so many barriers to organization, company subterfuge, violence, and social reprisals, speaks to the incredible struggle and undeniable character of those who fought for industrial democracy and social justice on the Ranges.

\footnotetext{
${ }^{84}$ Samuel Swanson, "Sam Swanson Radio Message on Labor Movement in Ely, Minnesota, and Iron Range," n.d., Samuel Swanson Collection, Minnesota Historical Society, St. Paul, Minnesota, Folder P187. ${ }^{85}$ Ibid.
} 
Most often mine managers like John C. Greenway, Pentecost Mitchell, and Thomas F. Cole are celebrated for their contributions to Iron Range history. What about people like Sam Swanson, Veda Ponikvard, Jospeh Mantel, and Fred Torma? These people fought to give workers a voice and as workers were the people who made the actual wealth, their stories are just as, or most important than the mining men who denied so many of their basic human rights.

One of the first major fights for such basic human rights occurred, fittingly, at the first commercially profitable mine. Workers at the Minnesota Mine on the Vermilion Range commenced an impromptu strike on June 23, 1892, when mine management "laid off" 315 men for fourteen days. There was context to the layoff, however. Days before being put out of work, hundreds of the mine's Austrian workforce took the day off to observe Corpus Christi day, an important religious holiday for Catholics. The mining company retaliated with the layoffs and refused to give the mineworkers their wages. The Vermilion Iron Journal, a company sponsored newspaper, spun the story regarding the refusal to pay workers, "on Saturday, the crowd of strikers called in a body at the [mine] office and demanded their wages. Although it was the company's intention to pay the roll that day, for the welfare of the community and the safety of its own property payment was postponed, it being anything but advisable to furnish the half-drunken mob the wherewithal to purchase more intoxicants." Again, the overt anti-immigrant sentiments of the Ranges' bosses, and their newspapers, had reared their ugly heads. Understandably, the immigrant mineworkers were infuriated by the wholesale punishment of workers and the refusal of pay. Approximately 400 or more took to the streets, shutting the mine 
down. Three companies of the Minnesota National Guard were called in, the strike leaders were arrested, and gradually "peace was restored." 86

Such loosely organized confrontations between labor and management occurred semi-frequently on the Ranges. Often such labor actions were confined to workers of similar ethnic background and Finnish immigrants quickly gained status as the Ranges' most proficient striking population. The Oliver's fear of and animosity toward organized labor, and those Finns affiliated with it, was well established. A letter dated January 20, 1903, from OIMC General Manager John Penguilly warned Oliver President Thomas F. Cole of the perils of Finns with the organizational impulse:

There has been, during the last part of the week, a man by the name of "Nasula," a Finlander, who hails from Hibbing, and he has been working among the Finlanders of Soudan and Ely. He is trying to start a labor union among the employees of the mine here. The matter was brought to my attention early, therefore I took steps to drive him from the places mentioned, and he has already retreated from the Vermilion Range and gone to the Mesabi Range, in which he claims he could start a union. This [information] may be of benefit to the Mining Men under you located on the Mesabi Range, so as to keep a look out for him and suppress him as soon as possible wherever he should turn up. ${ }^{87}$

In Minnesota's Iron Country, Finns became the primary agitators in labor confrontations. A June 6, 1904, strike bore witness to this claim. On that day 400

${ }^{86}$ Vermilion Iron Journal (Tower, Minnesota), June 23, 1892.

${ }^{87}$ John Penguilly to T.F. Cole, "Materials Relating to the Oliver Iron Mining Company," January 20, 1903, Minnesota Historical Society Archives, St. Paul, Minnesota. 
mineworkers walked out at the Drake and Stratton Stripping Operations of the Oliver's Fayal Mines in Eveleth. The OIMC had just announced a wage reduction from $\$ 1.75$ a day to $\$ 1.60$ a day and the mostly Finnish immigrant mineworkers were unwilling to accept the wage reduction. On the third day of the strike, a clash between the strikers and armed mining company deputies elevated the stakes of the strike. Two Finnish strikers ended up in the Eveleth hospital. One died with a bullet in his skull and the other striker suffered a jagged shell wound to his chest. This clash set the tone for the turbulent years ahead, as mineworkers, most often Finns, continued to strike amidst mine shutdowns and armed mining company guards into $1905 .{ }^{88}$

Previous labor actions on the Ranges had lacked formal union representation, but in 1905 that changed. On April 13, 1905, a committee of unorganized mineworkers' representatives went before OIMC Mine Superintendent Pentecost Mitchell. Mitchell refused the committee's demands and the workers decided to continue the strike for two weeks. On April 15, 1905, the OIMC ordered a general shutdown of its operations. Into this labor action, the Western Federation of Miners (WFM) appeared to help organize the mineworkers. The WFM had little impact on the OIMC's treatment of the mineworkers, however. The strike broke down and many of the miners returned to the mines at the $\$ 1.60$ a day wage. The more vociferous workers gained the agitator label. The agitator label guaranteed miners a membership on the Oliver's notorious blacklist. ${ }^{89}$ As the WFM

\footnotetext{
${ }^{88}$ Rudolf Pinola, Labor and Politics on the Iron Range of Northern Minnesota, Unpublished Ph.D. Dissertation, University of Wisconsin, 1957, 17-20.

${ }^{89}$ Ibid.
} 
appeared on the Iron Range to organize the miners in 1905, the Oliver met the organizational attempts with disdain and repression.

\section{The 1907 Mesabi Range Strike}

Between 1905 and 1907, the WFM increasingly sent recruiters into the Iron Ranges. By 1907, the WFM was already a well-established militant industrial union being founded in 1893. Born of struggles in the hard rock mines of the American West, the WFM had a reputation for combativeness that was exacerbated by its 1905 joining with the upstart, revolutionary IWW. As A.M. Stirton, editor of Michigan's pro-IWW newspaper the Wage Slave, remarked about the merger, "let us get busy then and organize into great Industrial Unions competent TO STRIKE AND STAY, that's the word, not to strike and leave as the manner of the Craft Unions is. Get busy and build up the I.W.W. Let every miner in the country join the Western Federation of Miners, and let the Western Federation of Miners swing into line and take its place where it ought to be in the I.W.W." 90

Founded in Chicago in 1905, the IWW was a grand aggregation of radical organized labor, but the WFM was the largest body pulled into the Wobbly's orbit. The express purpose of this new conglomeration was to seize control of the means of production for the benefit of the workers who lived and died in such industrial settings. The IWW was a revolutionary industrial union. As one Wobbly treatise announced, "the power of the workers in production," it was argued, "is the power of the life and death over society." A unique non-Marxist critique of industrial labor stood at the center of

\footnotetext{
${ }^{90}$ Wage Slave, April 24, 1908.
} 
Wobbly ideology as the union maintained that human labor power was the source of all wealth and that capitalists sought to fragment the common interests of what the Wobblies called "Fellow Workers," stating, "the interest of the capitalist lies...in forcing, if they can, a lower living standard upon the workers. Naturally the interest of the workers lies in not only maintaining their present standard but in trying to elevate it. This antagonism is an evidence of what we know as the class struggle." Though other segments of life, such as culture, media, politics, and religion, reinforced the exploitation of the working masses, the IWW situated their revolutionary impulse directly at the point of production. It was here: on the shop floor, in the wheat fields, and in the open pit mines, that inequitable economic and power relations were experienced most directly and in that setting where the true source of socioeconomic power was located..$^{91}$

The IWW was a unique organization in the nascent years of United States organized labor. The main impact of the IWW to the North American labor movement was in placing a revolutionary aim and purpose alongside the industrial unionism that was gradually developing among the American working class. Industrial unionism was a response to the dominant craft or trade form of union organization. Craft or trade union organization, according to the founders of the IWW, was becoming outmoded and ineffective due to the rise of mass production industries that was replacing craft production. The application of machine technology and the subsequent industrialization, standardization, and de-skilling of the labor process - already well underway in the early

\footnotetext{
${ }^{91}$ Industrial Workers of the World, An Economic Interpretation of the Job, (Chicago: Department of Education, Agricultural Workers Industrial Union, 1922). Accessed online: https://www.marxists.org/history/usa/unions/iww/1922/economic.html, May 1, 2014.
} 
twentieth-century and later expanded by assembly line production and "scientific management" techniques_-was beginning to make some trades obsolete. The IWW sought to counteract this march toward industrialization with controversial tactics that included organization of unskilled workers, industrial sabotage, and the ultimate weapon - the general strike, which was designed to shut down entire economies. ${ }^{92}$

The Wobblies were an industrial union that argued craft unions divided workers in the same workplace or industry into multiple bargaining units. Craft or trade union autonomy, which provided the restrictive rules for each compartmentalized industrial unit meant that only a certain portion of workers, usually skilled laborers or craftspersons, in a given industry were available to organize. During labor actions this often resulted in the defeat of unskilled workers who had little economic, political, or shop floor capital. The Wobblies argued that craft and trade union segmentation undermined working-class unity. The IWW proposed an alternative model of industrial organization that would place all the workers in a single workplace or industry into the same union, regardless of the tools they used in the process of production, and all industrial departments into One Big Union or the OBU. Perhaps most importantly unlike many craft unions or associations of labor such as the AFL in the early twentieth-century, membership in the IWW was unique in that it was open to any worker regardless of gender, race, creed, or ethnicity. ${ }^{93}$

\footnotetext{
${ }^{92}$ Saku Pinta, "Interview on IWW History," conducted by Gary Kaunonen, Thunder Bay, Ontario, Canada, May 1, 2014.

${ }^{93}$ Pinta, "Interview on IWW History," and William E. Trautmann, Why Strikes are Lost \& How to Win, (New Castle, PA.: I.W.W. Publishing Bureau, 1912). Accessed online: http://www.iww.org/history/library/Trautmann/loststrikes.html, May 1, 2014.
} 
Wobbly historian and political scientist Dr. Saku Pinta argues that "this approach was designed to maximize the class solidarity necessary for countering the increasingly concentrated power of employers in industrial disputes," citing an IWW edict that "the longer the picket line, the shorter the strike." Pinta's work also has indicated that improvements in wages, hours, and working conditions were essential, but the ultimate aim of the IWW was the overthrow of the capitalist system. The industrial unions of the IWW were structured in such a way as to organize the working class into various branches and departments that would approximate future worker self-managed arrangements known as "building the new society within the shell of the old." The Wobblies did not base their vision of a socialist society, sometimes referred to as "industrial democracy" or the "cooperative commonwealth," on an idealized conception of the past, but looked forward to an epoch when human creativity, ingenuity, and technology could be harnessed to benefit humanity as a whole, rather than a privileged elite. The state apparatus would be replaced by industrial administration. Class divisions and the wage system were to be abolished in favor of common ownership, with production for use rather than profit as the guiding principle. The industrial unions were to be the embryonic form of the approaching socialist society in the present day. ${ }^{94}$

By 1907, the WFM was successful in signing up approximately 2,500 miners on the Mesabi Range and was set to make another attempt at a significant labor stoppage. ${ }^{95}$ Immigrant Finns were at the forefront of the WFM's rank-and-file, but the administration

\footnotetext{
${ }^{94}$ Saku Pinta, "Interview on the IWW."

${ }^{95}$ Michael Karni, "The Founding of the Finnish Socialist Federation," in For the Common Good: Finnish Immigrants and the Radical Response to Industrial America, (Superior, Wisc.: Työmies Society, 1977$), 74$.
} 
of the 1907 Mesabi Strike came under the supervision of Italian immigrant organizer Teofilo Petriella. ${ }^{96}$ On July 19, 1907, Petriella and the WFM demanded two concessions from the OIMC. The first demand was that the OIMC end the "contract system of mining." The dubious contract system of mining provided numerous opportunities for graft on the part of mining captains. The contract system of mining paid miners for iron ore worked in a day. If a miner were stuck in hard rock, the payment for the day would decrease. Conversely, if a miner were in soft, workable rock, the payment for the day would increase. Mining captains sold the soft rock to miners for a price. This was the basis of graft in the contract system of mining. The contract system of mining was to be a point of contention between labor and the mining companies for years to follow. The WFM's second demand was that the mineworkers receive a flat wage for an eight-hour workday. For a common mine laborer the wage was to be $\$ 2.50$ a day, $\$ 3.00$ a day for foremen, and $\$ 5.00$ a day for engineers. ${ }^{97}$

The OIMC did not meet the demands of the WFM. Petriella retaliated by calling out the mineworkers of the Mesabi Range on July 20, 1907. ${ }^{98}$ The WFM, Petriella, and the striking workers who followed them were branded as anarchists mainly because of the Socialist Finns who advised them. ${ }^{99}$ In a July 23, 1907, newspaper article, the procompany Mesaba Ore editorialized that "it was a mark of note that fully ninety-percent of those in line at the Hibbing Miners' Parade were Finlanders-fiery followers of the Red Flag in that procession.” The rampant anti-immigrant attitudes of the Ranges' native

\footnotetext{
${ }^{96}$ Pinola, "Labor and Politics," 20.

${ }^{97}$ Ibid., 21.

${ }^{98}$ Ibid., 22-23.

${ }^{99}$ Karni, "The Founding of the Finnish Socialist Federation," 65-70.
} 
American population were on display in the Ore's chronicling of the strike, "of those marching, not one American appeared in line. It was a representative gathering of a class that wants this country run on the socialist plan, and who are willing to resort to all meaning of lawless acts to instill the reform they seek." ${ }^{100}$ As a result of the strike, not a shovel moved on the Mesabi Range. Mining activity at the OIMC's mines came to a standstill in Hibbing, Eveleth, and Virginia—shut down by labor agitators and immigrants who had, in most cases, been in the country for less than a decade. ${ }^{101}$

The Oliver was terribly concerned that the strike activity of the Mesabi Range would filter into the Vermilion Range. In a letter to the Oliver's General Superintendent Charles Trezona, Assistant Superintendent P.F. Chemoream wrote, "last Monday night a couple of Finns, from the Missabe Range, presumably Socialists, attempted to get the Finn Hall here to talk to the miners. The hall was refused them, as it has been in one previous instance." The Oliver was willing to use whatever means necessary to stop the strike from spreading, including violence, as Chemoream continued, "I am equally positive that in case of interference from the Western Federation of Miners we can raise 175 men, who want to work and protect their homes, to escort these Socialists to the Town line South and help them on their way. However, I am hopeful that such a measure will not be necessary and that we can work without any trouble." 102

Company police attempted to break the strike using whatever means necessary. In an August 5, 1907, letter back to his family in Finland, recent immigrant Victor

\footnotetext{
${ }^{100}$ Mesaba Ore (Hibbing, Minnesota), July 23, 1907.

101 Pinola, "Labor and Politics," 21-23.

102 P.F. Chamoream to Charles Trezona, "Business Correspondence,” July 24, 1907, Materials Relating to the Oliver Iron Mining Company, Minnesota Historical Society Archives, St. Paul, Minnesota.
} 
Myllymäki recalled the violence, "there is a strike going on here [in Eveleth]. There are many of us out of work. I don't know how long the strike will last. It's only been two and a half weeks since it started and this isn't a very pleasant time at all. There are 100 stooges with guns paid by the mining companies harassing the workers just like some animals. A worker can't peacefully walk down the street anymore. People are jailed every day." Myllymäki went on to opine about his experiences with company goons and the power of mining companies on the Iron Range, "they say this America is the land of the free but that's a lie." 103

The only act of violence from the "anarchist" strikers in the 1907 strike came on August 8. Finnish immigrant strikers went to a boarding house maintained by two women near the Burt Mine in Hibbing and physically demanded that the boarding house take no "scab" miners. When the police arrived on the scene, the Finnish strikers dispersed. Police seized nineteen of the strikers and brought them before Judge Brady in Hibbing. Ten received jail sentences for inciting and participating in a riot. ${ }^{104}$ While area newspapers bemoaned the scourge of immigrant workers organizing to better their lives, the Oliver imported over 1,100 immigrant "Austrians," 105 to take the place of striking mineworkers. Finnish immigrant socialists tried their best to rally the rank-and-file miners by opening their social halls on the Mesabi. This measure was of little use because

\footnotetext{
${ }^{103}$ Victor Myllymaki, "Personal Correspondence," quote from excerpt letter in Peg Meier, Bring Warm Clothes: Letters and Photos from Minnesota's Past, (Minneapolis, Minn.: Star Tribune Company, 1981), 208.

${ }^{104}$ Pinola, "Labor and Politics", 24.

105 The use of Austrian at this time period referred to a number of ethnicities that were administered to by the Austrian Empire. Included in the Austrian designation are peoples from current day Hungary, Croatia, the Czech Republic, Montenegro, Romania, Poland, Slovenia, Serbia, Ukraine, Slovakia, and a number of other ethnic minorities. The "Austrians" on the Mesabi Range were primarily Croatian, Slovenian, and Montenegrin peoples.
} 
the OIMC began to reopen the Mesabi mines with the strike-breaking Slavic mineworkers. ${ }^{106}$

The 1907 strike lasted in the general mineworkers' population for roughly three weeks. The Virginia Enterprise declared the strike all but broken on August 9. Most mineworkers were preparing to return to work within the next week, with one exception, the holdout Finnish immigrant strikers and their families. Of the striking Finnish immigrant mineworkers, the Enterprise editorialized in an August 9, 1907, article, "thus far no definite sign of weakening has been manifested on the part of the Finnish miners and workmen constituting in great degree the striking element." 107 The OIMC's response to the 1907 strike was to blacklist the strikers. The predominant ethnic population on that blacklist was Finnish. The Oliver blacklisted some 1,200 Finnish immigrant mineworkers from across the Mesabi. The blacklisting of so many Finnish immigrants from the Mesabi's mines meant that after the 1907 Strike, Finns made up less than eight percent of workers on the Mesabi. Remarkably, before the 1907 Strike Finns comprised nearly twenty percent of the working population in area mines. ${ }^{108}$

Table 2.1, located below, analyzes the major ethnic groups working in the Oliver properties post-1907 Strike. Of these major ethnic groups, the three main immigrant ethnicities and native American working populations are shown. The table visually depicts that the depleted number of Finnish immigrant workers, post 1907 Strike, is in stark contrast to the Austrian workforce. Austrian workers were used to break the strike,

\footnotetext{
106 Karni, "The Forging of the Finnish Socialist Federation", 75.

107 Virginia (Minnesota) Enterprise, August 9, 1907.

${ }^{108}$ Karni, "The Forging of the Finnish Socialist Federation," 78.
} 
and took the positions of Finnish immigrant workers en masse in many of the Oliver's mines. The Oliver's Italian ethnic working population was reduced as well after the strike, though it never amounted to the number of Finnish immigrant workers employed in the Oliver's mines before 1907. The importance of the Italian immigrant striking population during the strike was perhaps exacerbated by the fact that the WFM's lead organizer during the strike was Italian immigrant Teofilo Petriella.

Table 2.1-Major Ethnicities Employed by OIMC after the 1907 Mesabi Strike

Pop. and percentage American Austrians Finnish Italian

Mesabi Range

Hibbing Dist. $\quad 472,29.5 \quad 671,41.9 \quad 67,4.2 \quad 209,13.1$

Chisholm Dist. $\quad 149,9.1 \quad 1,002,61.5 \quad 154,9.5 \quad 155,9.5$

Mt. Iron Dist. $\quad$ 178, $24.7 \quad 236,32.8 \quad 170,23.6 \quad 36,5.0$

Fayal Dist. $\quad$ 262, $20.7 \quad 377,29.8 \quad 256,20.2 \quad 224,17.7$

Adams Dist. $\quad 283,21.5 \quad 603,45.7 \quad 140,10.6 \quad 177,13.4$

Canisteo Dist. $\quad 355,22.8 \quad 733,47.1 \quad 131,8.4 \quad 33,2.1$

Total Mesabi Range: $1,752,20.8 \quad 3,815,45.4 \quad 963,11.5 \quad 837,10.0$

$\underline{\text { Pop. and percentage American Austrians Finnish Italian }}$

Vermilion Range $\quad 99,12.9 \quad 402,52.5 \quad 175,22.9 \quad 30,3.9$

(underground)

In comparison with Minnesota's strike affected areas where Finns had been blacklisted from the Oliver's ranks, the OIMC continued to employ Finnish immigrant workers in Michigan's three iron ranges in comparable numbers with American, Austrian, and Italian workers: 


$\begin{array}{lllll}\text { Pop. and percentage } & \text { American } & \text { Austrians } & \text { Finnish } & \text { Italian } \\ \text { Marquette Range } & 739,49.5 & 40,2.7 & 372,24.9 & 178,11.9 \\ \text { Menominee Range } & 228,15.8 & 165,11.5 & 98,6.8 & 284,19.7 \\ \text { Gogebic Range } & 435,22.6 & 137,7.1 & 625,32.5 & 232,12^{109}\end{array}$

It is clear from the data that Finnish immigrant mineworkers had been jettisoned from the laboring masses at the Oliver's Minnesota mines. Many moved to and founded or occupied outlying agricultural hamlets such as Toivola, Cherry, Embarrass, and Floodwood. Interestingly, often many of these small rural hamlets composed of Finnish immigrants had three very distinctive features (besides the ubiquitous sauna dotting the landscape): a consumer's co-operative store, a social hall, and an auxiliary IWW local. Because the blacklisted mineworkers had moved to subsistence agriculture to make a living and were now non-industrial toilers of the land, they were no longer able to join the WFM/IWW. Thus, these former members of the WFM/IWW organized locals as auxiliaries and not as industrial union locals. The small rural co-ops that sprang up in these countryside locations, which also existed in some of the Ranges' urban areas, would prove essential to the 1916 Strike as they provided foodstuffs and organizational talent during the strike. ${ }^{110}$

\footnotetext{
${ }^{109}$ Table statistics and percentages come from data compiled and tabulated from the James S. Steel Collection, "Nationalities, Statistics, 1909," Minnesota Historical Society, St. Paul, Minnesota, Box 1, Folder 150.

${ }^{110}$ For a discussion of Finnish immigrants on the industrial periphery see Gary Kaunonen, Finns in Michigan, Discovering the People of Michigan Series, Lansing, Mich.: Michigan State University Press, 2009, and evidence of IWW agricultural auxiliaries can be found in various editions of the Finnish immigrant produced IWW newspapers Sosialisti and Industrialisti.
} 
Despite the use of imported Austrian strikebreakers, who took the place of Finnish and Italian immigrant strikers during the 1907 Strike, ethnic rivalry between Finns, Italians, and Austrians seemed to be negligible only a few years later. In an oral history Veda Ponikvard recalled, “well, no, they [Finns, Italians, and Austrians] weren't at odds [in Chisholm], simply because as a community they were helping each other, and the neighborhood was pretty much intermingled. You had Italians, Finns, [Czechs, Russians,] and Slavs living on the same block." The dissipation of ethnic rivalry after the 1907 Strike was likely helped by the growing class-consciousness of the former "scab" immigrant Austrian workers. Perhaps realizing that they had been used by mining companies during the strike, Ponikvard surmised that what happened to them during the 1907 Strike, "made them think and they began to realize that in their own mind that they were human beings, with certain inalienable rights... and they began to realize that there were certain things that they would have to fight for." She continued, "so, the 1907 Strike sort of opened the door for them. In 1916 they became a little more aggressive and they began to demand certain things, particularly better wages and better working conditions." 111

\section{Range Politics and the Progressive Era}

The fight for better wages, working conditions, and an improved social safety net was also being bolstered by a new social movement. In contrast to the revolutionary industrial unionism advocated by many of the Ranges' disenfranchised immigrant voters, the Progressive movement was a reform-seeking political ethos that was home to many

\footnotetext{
${ }^{111}$ Ponikvard, "Oral History," May 13, 1988. Ponikvard did state in the interview that while Chisholm was ethnically non-segregated, Eveleth's nationalities were more likely to live in distinct, ethnic neighborhoods.
} 
educated, middle-class Americans. This was yet another and incredibly important aspect regarding the Minnesota Iron Ranges' political and social landscapes during the early $20^{\text {th }}$ century. Most of the Ranges' immigrant mineworkers and their families had little say in the conditions of their labor. Their work, and in some instances, their cultural, home, and social lives, were handed down to them from managers at the mining companies. Politically, these immigrants had even less of a say in the election of public officials because most immigrants did not have the right to vote. In the late $19^{\text {th }}$ and early $20^{\text {th }}$ centuries, Range politics were dominated by men partial to mining companies. That all began to change with the coming of the Progressive movement. This movement, led by English-speaking, educated, middle-class reformers, sought to study, report, and ultimately change socio-economic ills. Progressives were steered by strong winds of change, but not revolutionary gusts. Progressives differed greatly from the IWW/WFM in this regard. The IWW/WFM sought to "create a new society in the shell of the old." It was a revolutionary industrial union, while the Progressive movement advocated reform and metered socioeconomic change. While essentially advocating the same idea, positive social change, Progressives and the IWW/WFM were in bitter opposition to one another. Thus, revolutionary industrial unionism was not just kicking against mining companies on the Iron Ranges, it was also at loggerheads with surging Progressive politicians who were winning elections to the Ranges' municipal governments.

Perhaps the best known Iron Range Progressive was Victor L. Power. There were a host of other Progressive politicians on the Ranges in the early $20^{\text {th }}$ century, but Power's dynamic character, forceful speaking style, and vaunted law degree set him apart from the Ranges' other Progressive politicians. Power also lived in Hibbing, the Range's 109 
most populous and influential city. Early in his life, Power, an Irish Catholic and dyed-inthe-wool Democrat, had worked in an area mine, but then attended college and eventually set up a law practice in Hibbing. He did all of this before entering politics, which he did in 1913 when he ran for mayor of Hibbing. Under the banner of "Progressives Win a Sweeping Victory in Election Yesterday," the Hibbing News Tribune lauded Power's victory along with a host of other Progressive politicians. The newspaper commented that "Victor L. Power, attorney-at-law, yesterday defeated Dr. H.R. Weirick, for seven years mayor of Hibbing, by a vote of two to one, receiving 722 to Mayor Weirick's 362," and that "the landslide which resulted in the defeat of the administration ticket was one of the most pronounced in the history of the city...it followed a short but heated campaign in which both sides put up a brisk fight and was a big surprise to those who have heretofore been a strong influence in controlling city elections." 112

After his election, Power took direct aim at these people who had had a "strong influence in controlling city elections," which was code for the mining companies. In 1915, he squared off directly with mine managers over taxes. In an effort to keep some of the wealth created on the Ranges in the Ranges, Power took his case to J.A.O. Preus, State Auditor of Minnesota. In a wonderfully crafted letter dated August 31, 1915, Power penned:

Some considerable time ago I wrote you informing you of the condition that existed in Hibbing with respect to the payment of taxes. I informed you that several of the mining companies had conspired together for the purpose of

${ }^{112}$ Hibbing News Tribune, vol. XIV, "Election Returns 1913." 
acquiring control of the village government of the Village of Hibbing, and, in furtherance of that conspiracy, they had agreed together to withhold the payment of their taxes justly and legally due, at the same time demanding from the Village of Hibbing that it surrender to them control of the Village government. The village being a branch of the state government and the village council believing that they were acting in accordance with the duties incumbent upon them by reason of their office, refused to surrender the rights of the people to the mining companies. Thus there was precipitated a fight over the amount of taxes that was justly due from these mine owners and especially from the United States Steel corporation to the State of Minnesota, to the school district of this vicinity, to the county of St. Louis and to the Village of Hibbing. ${ }^{113}$

In his tenure as mayor, mining company managers accused Power of extravagant spending, claiming that the spending was coming at the expense of taxpayer money. In turn, Power accused the mining companies of pilfering the resources of the State of Minnesota and leaving nothing but a treeless, tinder-dry physical and social landscape in their wake. It was a very populist and elegant argument that began with the concept of public ownership of resources, "the people of the Village of Hibbing believe that these ore bodies are not and should not be the property of individuals and in exclusion of the people, who are the rightful owners thereof, and they do not feel that it is extravagance to expend taxes for the purpose of bettering their condition and the condition of the state." Power ended his argument by suggesting that it was a waste to surrender the State's

\footnotetext{
${ }^{113}$ Victor L. Power to J.A.O. Preus, "Government Correspondence," August 1, 1915, Victor L. Power Papers, Minnesota Historical Society, St. Paul, Minnesota, Box 1.
} 
resources to "non-resident capitalists for expenditure outside of the state," and that "the pine timber of our state and the iron bodies were not created or enhanced in value by the act of these non-resident operators, but they were the gift of Providence for the benefit of society." 114

Power's strong language and populist argument appealed to many who saw the inherent inequality of Range life. In his campaign to wrest authority from mining companies, Power skillfully drew in the civic sensibilities of Rangers against probusiness provocateurs in Duluth who were rumored to be associates of mining company management. Duluth was, in fact, home to several regional offices for various mining companies with the Oliver, M.A. Hanna \& Co., and other operators keeping offices in Lake Superior's largest city. Power's written assault on the mining companies and thus their Duluth business associates and interests, caused the Duluth Herald and the Hibbing Tribune to wage a war of words in 1915 over the alleged affluence of Hibbing.

As a result of the acrimony between Power and mining company managers, a bill rumored to have come directly from the desks of Oliver management, was before the Minnesota legislature to "limit the expenditures of villages and cities on the ranges," and the people of Hibbing and the Hibbing newspapers took to task those looking to defame the city and its call for a larger piece of the mining company profits. Chortling about so called "facts" published in Duluth's Herald, the Hibbing newspaper reported that C.O. Baldwin and W.D. Bailey of Duluth, along with Edward C. Hale of Minneapolis, proclaimed "that Hibbing has paved virtually every street to the village limits and nearly

${ }^{114}$ Ibid. 
all of the alleys." 115 "THE TRUTH," according to the Hibbing newspaper was that "Not a single street in Hibbing is paved to the village limits. Not an alley in all Hibbing is paved. There are 23 miles of streets in the platted portion of Hibbing. There are 5.3 miles of paved streets in Hibbing, and that this is 23 per cent paved and 77 percent unpaved." Power also took out an advertisement in the same edition admonishing that, "the above statements [in the Hibbing Tribune] are TRUTH and not PAID FOR 'FACTS' 'developed' by representatives of eastern capitalists who fear that the people of Minnesota will get hold of some of Minnesota's wealth before they succeed in dragging it out of the state." 116

It seemed that Power and the IWW would have been natural allies in the struggle for industrial democracy and against the exploitation of mining companies. Ideology, however, split the two populist camps and the revolutionary goals of the IWW never matched the political reform perspectives adhered to by Power and the Progressives. Power flatly refused the revolutionary impulse and his allegiances to organized labor rested squarely with the conservative, craft and trades unions of the AFL. While his oratory and letter writing campaigns forcefully called for public ownership of natural resources, he could never quite make the jump to a revolutionary restructuring of society. For their part, the Wobblies were dismissive of electoral politics and staunchly antiestablishment. If the Wobblies were fanning the flames of discontent on a tinder-dry landscape in hopes of firing socioeconomic revolution, Power was looking for ways to

\footnotetext{
115 Victor L. Power, "Scrapbook: Newspaper Clippings," vol. 1, Victor L. Power Papers, Minnesota Historical Society, St. Paul, Minnesota, Box 1.

${ }^{116}$ Ibid.
} 
make it rain. Thus, the tinder-dry cultural, economic, political, and social landscapes of Minnesota's Iron Ranges were occupied by three distinct and prominent players: mine owners, reformers, and revolutionaries. The tense interactions between all three would create a volatile scene as each attempted to assert their identity and ideology on the Ranges' dynamic populations. 


\section{Section: Identity and Ideology}

\section{A Solidarity-inspired History Vignette: Phone Zaps}

As Solidarity-inspired History intends, struggles of the past can inform the future. The social actors, concessions asked for, and technology have changed over time, but the basic struggle informed by long-held ideological constructs remains constant. In 1916, on Minnesota's Iron Ranges the IWW was locked in battle with one of the most powerful corporations in the world_-United States Steel—which owned the Oliver Mining Company. As this chapter will highlight, the use of sabotage as a tool of the class struggle was heavily debated by IWW members from the rank-and-file to IWW organizers such as Elizabeth Gurley Flynn. Just what sabotage was and how it might be ethically employed on the shop floor or during strikes was the subject of countless intra-union arguments, pamphlets, and treatises. Most agreed that an element of sabotage was the conscious withdrawal of efficiency on the job by workers-strikes being the ultimate expression of this ideal. The general idea was to slow down production and hit employers squarely in the pocket book with decreased industrial output.

Much has changed since the early $20^{\text {th }}$ century, but sabotage as a weapon in the struggle for workplace rights still exits and the IWW continues to utilize this tool in dealing with unfair labor practices, but with a $21^{\text {st }}$ century twist. Wobbly member Deepan Budlakoti worked for Glen's Towing in Montreal, Quebec, Canada, from November 2013 to April 2014. Glen Comeau, owner of the towing company, either improperly filed Budlakoti's work hours or refused to report the worker's earned number of hours so that Budlakoti's application for employment insurance would be denied. The IWW came to the defense of Budlakoti's interests and called on the membership to employ direct action 
by contacting Comeau, asking the owner of the towing company to correctly refile Budlakoti's hours so that Canada's Ministry of Labor could process and grant Budlakoti's employment insurance. ${ }^{117}$

Much like the efficiency-zapping sabotage espoused by the IWW in the early $20^{\text {th }}$ century, the current IWW called for a "Phone Zap" against Glen's Towing and a subsidiary business 514 Towing, in October of 2014. Writing to the membership in a September 28, 2014, email, "from 9am - 5pm daily on Wednesday October 1st until Friday October 3rd, we'll be calling out to all members of the IWW to call/fax Glen's Towing to get F(ellow) W(orker) Budlakoti's Record of Employment corrected. Members can make multiple calls to the same number and identify themselves as IWW members, but get ahold of me directly if you're unsure of how to make a phone call to an employer like this. I'll have a script ready to work from." The idea of a Phone Zap, which has been utilized profusely by the current IWW, has its roots in the historical ideas of a conscious withdrawal of efficiency as the email intends, "let the dispatcher [who will be answering the phone] know what their employers are doing and that you would like to speak to them directly. Keeping this line open is in the [employer's] best interest, and jamming it with phone calls means they won't receive calls for towing jobs." 118

One-hundred years ago, sabotage meant slowing down industrial production. Currently, and in a contemporary North American economy that is moving increasingly toward service-based sectors, sabotage can mean preventing employers from efficiently

\footnotetext{
${ }^{117}$ Industrial Workers of the World to IWW-members List, "Personal Digital Communication: IWW Phone/Fax Blitz in Support of FW Budlakoti," September 28, 2014.

${ }^{118}$ Ibid.
} 
serving their customers if workers' rights are not adhered to by the "bosses." The economic and industrial landscape has certainly changed in the last one-hundred years, but the struggle for industrial democracy, workplace rights, and union representation remains the same. The IWW's participation in this struggle has endured, and they have seemingly met the changes and challenges of an evolving industrial workplace with creative, effective, and technologically appropriate agitation and organizational measures.

\section{Section Introduction}

Minnesota's Iron Ranges have a sense of place, an identity, that is all their own. In the late $19^{\text {th }}$ and early $20^{\text {th }}$ centuries, the Ranges were a rough and tumble landscape in an isolated, sometimes arctic, sometimes mosquito-infested tropical region that was gifted with an ever-increasing and changing multi-ethnic population. It was not, however, wholly dominated by these unique features. The Ranges' economic, cultural, social, and spatial landscapes were subjugated by powerful men running billion dollar corporations who sought to shape the identity of workers, their families, and their institutions into a profitable expression of American capitalist ideals. There were very few independent expressions of identity on Minnesota's Iron Ranges that did not revolve around companysanctioned lives. For workers, the struggle to craft an autonomous identity that existed outside the sphere of mining company influence was difficult to say the least. The need for powerful expressions of independence became an ideological imperative if workingclass populations on the Ranges were to ever assert a self-determining identity forged in their own image and interests. This section seeks to chronicle and analyze this struggle to create identity through the development of ideological working-class constructs. 
The discussion of such a topic is difficult because "identity" and "ideology" are broad and often misconstrued or over-generalized terms. Most scholars who study the development of identity argue that the term discusses two basic concepts: social and personal identity. In "Ideology, Identity, and Intercultural Communication: An Analysis of Differing Academic Conceptions of Cultural Identity,” Dr. Young Yun Kim proposes that cultural identity encompasses "a sociological or demographic classification," as well as "an individual's psychological identification with a particular group." In addition, she concludes that "both sociological and psychological meanings of cultural identity are regarded as two inseparable correlates of the same phenomenon." In the academy the term's meaning has evolved over time and Kim argues that scholarly conceptions of immigrant identity have shifted "in recent decades from the traditional 'melting pot' perspective on intergroup relations in the United States toward a more pluralistic perspective on ethnicity, race, and culture. This ideological change is reflected in a clear pluralistic turn in academic inquiry into cultural identity, along with an increasing salience of 'critical' scholarship adding its voice to, and challenging, the mainstream [conceptions] of cultural identity."119

While the formation of cultural identity is critical to understanding the self, the struggle to form or fit into a new national identity is especially prescient to immigrants. In Dr. C. Kendall Theado's article, “Narrating a Nation: Second Wave Immigration, Literacy, and the Framing of American Identity," she argues that "the U.S. has been

${ }^{119}$ Young Yun Kim, "Ideology, Identity, and Intercultural Communication: An Analysis of Differing Academic Conceptions of Cultural Identity," in Journal of Intercultural Communication Research, 36, 3, $2007,238$. 
regularly engaged in the narration of its nationality - that is the process of defining what it means to be an 'American' so that an individual can fully participate in the idea of 'America.' The broad and on-going project of nation-building, then, is perhaps best viewed as a simultaneous construction of both the nation's identity as well as the idealized identity of its citizenry." ${ }^{120}$ In this manner identity shapes personal experience and the social constructs that cause immigrants to join or resist a narration of nationality.

This tension between being an "American" and being an immigrant is the focus of social psychologist Dr. Kay Deaux’s work. An important concept within social identity when chronicling the lives of workers on the Iron Ranges is "intersectionality." In Deaux's article "Social Identity," she defines the term as "the condition in which a person simultaneously belongs to two or more social categories of social statuses and the unique consequences that result from that combination." ${ }^{121}$ For immigrants on the Ranges, this was a common part of everyday life. They lived lives in which intersectionality as members of an immigrant group—-be it Italian, Slovenian, Croatian, or Finnish—collided with and was simultaneously shaped by being members of an international working-class. At the same time these immigrants also existed on the margins of the American workingclass, which at times did not want to acknowledge any ties to these mostly unskilled, underpaid, and derisively mocked "un-American" general laborers. For immigrant mineworkers, "identity" was a precarious, shifting construct for strangers in a strange

\footnotetext{
${ }^{120}$ C. Kendall Theado, "Narrating a Nation: Second Wave Immigration, Literacy, and the Framing of the American Identity," in JAC: A Journal of Rhetoric, Culture, and Politics, 33, 1-2, 2013, 711.

${ }^{121}$ Kay Deaux, "Social Identity," accessed at http://www.utexas.edu/courses/stross/ant393b_files/ARTICLES/identity.pdf, on November 15, 2014.
} 
land who were actively being assimilated, exploited, and shaped into ideal workers by capitalist overseers.

As the IWW worked to organize immigrant workers, they carefully crafted and communicated symbolic representations of what it meant to be an industrial worker in both an American and international working class. The melding of immigrant identities with that of international-industrial-worker-in-America identities was the IWW's goal as they hoped to cultivate solidarity between their immigrant rank-and-filers. The Wobblies hoped to forge this identity and then transmit ideological imperatives that stressed collective action against a mutual adversary: industrial capitalists. Such ideological representations of identity sought to cultivate the "commonly shared and collectively elaborated beliefs about social reality consensually held by members of [the IWW's] culture or subculture." It was important for the IWW to establish cohesion of practice and thought among their immigrant members. Therefore, it was the job of ideology to link these disparate social actors who were intersectionally disjointed-members of ethnic brotherhoods, radical political organizations, and/or various religious benefit societies, yet at the same time members of an American working-class in an adopted homelandtogether in the hopes of taking on powerful, multinational, and multimillion dollar mining corporations.

Especially illustrative of the interconnectedness of ideology and identity is the creation of unique personal attitudes and social behavior in the collision of immigrant expectations and perceived reality in a new land. Ideology, in working-class immigrant populations, can become an expression of the mixed collective experiences of a discontented underclass population through shared personal experiences to form new 120 
expressions of resistance to economic, cultural, or social norms. Immigrant identity on the Ranges was defined by adoption of, or resistance to, the normative behavior expected by mining companies, which was equally ideological in nature. Resistance to being good workers who were complacent in the capitalist system was reinforced by the IWW as they sought associates in the struggle against capitalism. These immigrant workers were not, however, passive recipients of Wobbly ideology. They actively aggregated, created, or reshaped the IWW's ideology. Unlike immigrants' ideological collision with American capitalism, their relationship with the Wobblies' ideological constructs was a symbiotic relationship that benefitted both the union and the immigrant rank-and-file. Immigrant success in joining an American working-class organization such as the IWW did not ameliorate the perils of industrial life in northern Minnesota. All that mining companies had to do to reject immigrant Wobbly identity was to ignore, imprison, or imperil the IWW, its organizers, and the rank-and-file. This would work for a time before 1916, but as the IWW's leaders developed more effective organizational strategies and tactics at the point of production, immigrant workers refuting capitalist norms became more difficult to control. The struggle to gain union recognition, however, was just one aspect of the forging of immigrant working-class identity. Even after the Ranges' immigrants were affiliated with an American labor organization, they were still in a precarious situation: workers in a dangerous industrial landscape who did not hold the power to assert a democratic voice in determining their socioeconomic surroundings. Membership in the IWW was one method to gain this voice in the workplace-the predicted social revolution would follow after the democratization of industrial spaces. The development of an ideological political consciousness was another means for 
immigrants to develop identity. In an article titled "Ideology: A Definitional Analysis," Dr. John Gerring argued that studying how actors "operationalize" the political landscape can demonstrate how "ideological the mass public is, versus the political elite" and "how political discourse is filtered to, affected by, and affected on the public at large." ${ }^{122}$ Thus, in many ways political identity, because it highlighted the disenfranchisement of immigrant workers, operationalized the inequalities of life on the Ranges. This intersection between working-class identity and political ideology can most properly be described as a nascent examination of identity politics.

Conceptually, identity politics seeks to understand the inherent contradictions and inequality of marginalized populations. As a means of inquiry, identity politics also seeks to redress such marginalization by expressing ways of understanding difference while seeking to challenge hegemony by enabling marginalized actors to assert greater selfdetermination in sociopolitical circumstances. Identity politics sheds a light on oppressive sociopolitical structures. For immigrants on the Ranges hoping to forge a sense of identity, the most overtly denied expression of sociopolitical engagement was "the vote." Most of the Ranges' working masses were not enfranchised and this lack of voice in such a polarized landscape had exploitative and repressive consequences. In his essay on this topic, "Five Theses on Identity Politics," Dr. Richard D. Parker argued that "political freedom is shaped by three simple norms: political equality, popular sovereignty and, therefore, majority rule." In contrast to Parker's standards, these hoped for democratic norms were conversely situated on the Iron Ranges. For the Ranges' immigrant

\footnotetext{
122 John Gerring, "Ideology: A Definitional Analysis," in Political Research Quarterly, Vol. 50, No. 4,
} 1997, 957. 
populations, there was no political equality as most immigrants were not citizens and could not vote. Popular sovereignty was almost non-existent for immigrants as many lived in mining company shacks, on mining company property, where mining company police enforced a public morality influenced by capitalist dogma. Essentially, the Iron Ranges were comprised of closely monitored work and social spaces where a few men and their managerial representatives ruled a large, politically voiceless laboring mass.

Ideological expressions of autonomy and working-class identity such as workers' co-operatives, ethnic benevolent societies, and increasingly, antithetical organizations opposed to capitalism, were the only means of achieving Parker's termed political equality. Corporately controlled, disenfranchised, and demeaned immigrants found that unions such as the IWW, which argued that politics was a tool of the "bosses" to keep workers enslaved, were sometimes the only points of access, or most forceful, toward the expression of an autonomous working-class identity. For this reason, the IWW's apolitical ideology gained many converts in the Ranges' immigrant populations. The two chapters in this section will analyze the struggle of immigrant groups on the Ranges' as they attempted to forge a self-determined industrial identity; chronicle their efforts to adopt or innovate new responses to exploitation; and consider the tension between identity politics and an increasingly apolitical immigrant population. Especially of interest is the IWW's controversial advocacy of industrial sabotage as a response to worker exploitation. Adoption of this ideological construct indicated that increasingly radicalized immigrant members of the IWW had jettisoned hope that the political process would help their plight. 
In analyzing the aforementioned, these chapters highlight the case of Finnish immigrants in their quest to establish an autonomous working-class identity and examine their intersections with the IWW's ideological background. As established in the first section, there were numerous ethnic populations seeking to create a separate identity in northern Minnesota, so why hone in on the Finnish immigrant experience? Quite frankly, Finnish immigrants are selected here because they had the largest and most welldeveloped cultural and social apparatuses in the struggle to forge a working-class immigrant identity. Early in their American industrial lives, Finnish immigrants sought to counteract the inherent contradictions of industrial exploitation and did so largely through education. The utilization of education to transmit ideological imperatives existed early in the Finnish immigrant experience in America. Though most had been in the United States for less than a decade, Finnish immigrants founded and joined Finnish-language federations of the Socialist Party of America, established a working-class institute of higher education, and developed a dynamic cultural apparatus that included identification with both Finnish immigrant and American identities. In this intersectional associational life Finns came in to contact with the IWW's apolitical industrial unionism and many became impassioned and stalwart advocates of the IWW. Studying the Finnish immigrant intersection with the Wobblies demonstrates the somewhat turbulent, but successful struggle to craft an autonomous, self-determined, and intersectional working-class identity through the successful implementation of the IWW's ideological imperatives. 


\section{Chapter 3:}

\section{Collecting Kindling-Radical Education and Literacy in Identity Formation}

\section{Chapter Introduction: Radical Education and Literacy in the Early $\mathbf{2 0}^{\text {th }}$ Century}

In the creation of working-class immigrant identity, education was a foremost concern.

On the shop floor, or in this case the iron ore pit, in social halls, and interestingly enough for one working class ethnic population, in the classroom, education was one of the primary goals in the development of an ideologically-based working-class identity. Collecting the various groups of ethnic workers together and getting them in the same building was just one task in organizing the 1916 Strike. A more monumental task was educating the proletarian masses - in some ways, a goal was basic literacy, and in other cases, the objective was to create a broader class-consciousness or a working class literacy of sorts. Inherent in the efforts to organize workers on Minnesota's Iron Ranges was the development of an American working-class identity via a class-conscious literacy that would lead to manifestations of a positive and proactive assertion of "voice," and the IWW benefitted from Finnish immigrant Wobblies' enthusiastic acceptance of this task.

In the late $19^{\text {th }}$ and early $20^{\text {th }}$ centuries, as literacy programs began to filter into the lives of the industrial proletariat around the world, working-class organizations attempted to expand the definition of literacy past basic reading and writing skills. This occasioned the rise of institutions that defined literacy as not only reading and writing, but also as knowledge of socioeconomic conditions. The first hurdle to organizing the masses against statist or religious education was dissemination of fundamental information. This chapter will examine aspects of the IWW's efforts at creating workingclass identity through literacy and education. In working toward this goal, this chapter 
will highlight the work of educating a regional industrial proletariat at a Finnish immigrant school known as the Työväen Opisto, or Work Peoples' College, located in Duluth, Minnesota, less than seventy miles from the epicenter of the 1916 Strike.

Literacy is a powerful word that means nothing to those who cannot read it, but for a significant period of the late $19^{\text {th }}$ through early $20^{\text {th }}$ centuries, the struggle to craft programs of literacy and education for the working class took on new and innovative directions. As the push to develop literacy programs among the masses commenced under the regulation of religious and middle class administration, a struggle emerged to formulate and implement a class-conscious pedagogy that embraced working-class values and egalitarian educational principles.

The groups of people targeted for literacy programs in this industrial age were working-class populations who had little previous say in their own education. Many who worked to educate the working-class regarding their plight as wageworkers concluded that statist, religious, and company-sponsored literacy and education programs sought to create a pacified underclass and placated workforce. As the benefits of industrialization lined the pockets of robber barons, steel magnates, and monopolists, and before the institution of secular educational opportunities afforded by public educational institutions, there was a struggle to carve out a place for literacy and educational programs among the burgeoning industrial working masses, on their own terms. For members of the working-class the occasion to define and implement literacy programs and educational opportunities free from others' class background created an opportunity to learn that was void of class influences. 
Like so many other aspects of the industrial life in this era, opportunity to shape and access to learn was contingent upon power relations. Because of this, perhaps one of the most truly proletarian and successful ventures into education and the teaching of basic literacy skills to the working masses were anarcho-syndicalist and industrial unionist efforts to create a democratic and proletarian-centered education. It is perhaps fitting that this mechanism to bring literacy to the masses came from an anarchist background because there was likely no better way to subvert the power relationship in literacy and education than by advocating for the destruction and obliteration of the very social system that kept a truly proletarian-themed education dislocated from the masses. Anarcho-syndicalist literacy efforts, much like the IWW's goals to reorganize society, invariably meant, "forming the structure of the new [educational system] within the shell of the old." 123

\section{“Jack-pine Savages" and Radical Education}

An immigrant group that had a very significant effect on the attempt to transform the inequalities of industrial life and bring about such a new society was Finnish immigrants. Often described as agrarian, clannish, socialistic, and slated for exclusion under early $20^{\text {th }}$ century “anti-Oriental” immigration policies, Finns were a small, but well-known immigrant population. The Lake Superior basin and especially Michigan's Upper Peninsula and Minnesota's northeast, beckoned many immigrant Finns. A 1918 review of Finnish immigration by geographer Eugene Van Cleef outlined the major factors that induced a majority of immigrant Finns to settle in northeastern Minnesota.

\footnotetext{
${ }^{123}$ Industrial Workers of the World, What is the I.W.W. Preamble? A Dialogue, $4^{\text {th }}$ printing, (Chicago: Department of Education, Agricultural Workers Industrial Union, 1923), 33.
} 
"The vicinity of Lake Superior seems to constitute the haven of refuge for the Finns. Their density is greater here than in any other equal area in the country." ${ }^{124}$ Van Cleef's research indicated that St. Louis County, in northeastern Minnesota, had an area of 6,503 miles, and a population of 163,274 in 1910 ; of this, 16,381 were Finnish in origin. ${ }^{125}$

Van Cleef pondered the Finnish attraction to northeastern Minnesota when he asked, "In view of the many hardships with which the settler in northeastern Minnesota must contend, one naturally wonders why the Finns continue to assemble here?" ${ }^{126}$ Van Cleef concluded the factors that pulled the Finns to northeastern Minnesota were geographic in nature, theorizing that Finland and northeastern Minnesota shared geographic similarities in landscape, climate, and flora. ${ }^{127}$ To supplement his findings Van Cleef interviewed sixty Finnish immigrants in St. Louis County, which were denoted as representative voices of the Finnish population in St. Louis County. One such interviewee offered an explanation of northeastern Minnesota's attractiveness to Finnish immigrants followed:

Some came to work in the mines to make money, as my brother did, intending to return to Finland. But, like others, after a few years he quit the mine and began farming, his natural occupation. The similarity of this North Country to Finland caused those who came before me to become enthusiastic and to send for their friends and relatives. ${ }^{128}$

\footnotetext{
${ }^{124}$ Eugene Van Cleef, "The Finn in America," in Geographical Review, Volume 6, Issue 3, September 1918; available at http://www.jstor.org; February 17, 2003, p. 188.

${ }^{125}$ Ibid., 188.

${ }^{126}$ Ibid., 194.

${ }^{127}$ Ibid., 195-198.

${ }^{128}$ Ibid., 205.
} 
As the interviewee indicated, employment in the region was also an important pull factor for Finnish immigrants. Thus, in addition to geography, economic opportunity, or at least perceived economic opportunity, must also be considered as a factor in brining Finnish immigrants to the Lake Superior region. At the height of Finnish immigration to the United States in the early $20^{\text {th }}$ century, the Lake Superior basin was home to an impressive and well-developed industrial landscape. The first Finnish immigrants to the region came to work in copper mines on Michigan's Keweenaw Peninsula in the mid1860s. After that initial contact, thousands of Finnish immigrants streamed into Michigan's Upper Peninsula; later immigrants made their way to northeastern Minnesota as the iron ore mining boom reached unprecedented levels of industrial output. ${ }^{129}$

The interviewee's recollection was a revealing statement because it not only described the geographic and economic basis for settlement in northeastern Minnesota, it also hinted at the supposed cultural clannishness of the Finnish immigrant and the desire to someday return to Finland. Early Finnish immigrants were stigmatized as an outgroup. As sociologist Peter Kivisto noted:

Finns occupied the status of a definite 'out-group' even though they are white Protestant. They were depicted as “Jackpine Savages," Mongolians (in 1907, an attempt was made to deny them citizenship by invoking existing anti-Oriental legislation), and violence prone revolutionaries. As a consequence of this

\footnotetext{
${ }^{129}$ For a discussion of Finnish immigration to Michigan's Upper Peninsula see Kaunonen, Finns in Michigan.
} 
prejudice, the climate was favorable for a variety of repressive actions, including imprisonment and blacklisting. ${ }^{130}$

Though the intention of some Finns in America was to someday return home, as roots grew, Finns began to settle permanently in the United States. As the Finnish immigrant population of northeastern Minnesota continued to grow, the impulse to shape, reform, and transform life on the Iron Ranges grew as well. The Finns who left Finland with a socialist predisposition carried the torch of socioeconomic transformation from Finland. In America's industrial setting, many more Finns were convinced of the need to foster and support social justice movements that dealt with the exploitation they saw daily. The influence of the "Red Finn" began to flourish in America.

The number of Finnish immigrant socialists grew in relative isolation, brokered by the common bond of ostracism from the American ideal, especially as Finnish immigrants gained a reputation for leftist politics. As Finns began to clash with American industrial and conservative political practices, their penchant for protest and organizational skills catapulted them to important places within early $20^{\text {th }}$ century social and union organizations. Finnish immigrant socialists were the first and largest ethnic group to set up their own internal language federation within the Socialist Party of America. The Suomalainen Sosialistijärjestö (Finnish Socialist Federation-FSF) was a Finnish language federation founded in $1906 .{ }^{131}$ The FSF organized in Hibbing,

\footnotetext{
${ }^{130}$ Peter Kivisto, "The Decline of the Finnish American Left, 1925-1945," in International Migration Review, Volume 17, Issue 1, Spring 1983, available at http://www.jstor.org; accessed February 13, 2003, p. 68.

${ }^{131}$ Michael M. Passi, "Finnish Immigrants and the Radical Response to Industrial America," in For the Common Good: Finnish Immigrants and the Radical Response to Industrial America (Superior, Wisconsin: Työmies Society, 1977), 12.
} 
Minnesota, on the Mesabi Iron Range. Two-dozen delegates from regional Finnish socialist organizations came together to form this grand socialist federation. Regionally, the FSF grew meteorically in the following years as successive waves of Finnish immigrants settled on the Iron Ranges. In 1906, at the time of the FSF convention in Hibbing, Finnish socialists claimed fifty-three locals with 2,622 members. In 1909, 162 FSF chapters claimed an enrollment of 5,100 members. That figure rose in 1912 to 13,667 members in 217 FSF locals spread across twenty-nine states. ${ }^{132}$ In 1912, six years after the FSF organized, membership grew to 13,000 people. At this time, the FSF constituted approximately fifteen percent of the Socialist Party of America's membership. ${ }^{133}$

The FSF grew rapidly from 1906 to 1912, but as the FSF grew, a schism developed among internal rival factions. This division, between revolutionary and parliamentary elements of the FSF membership, had its roots in the 1907 Mesabi Strike, which occurred just one year after the FSF's 1906 founding convention. ${ }^{134}$ During the 1907 Mesabi Iron Strike, socialist-unionist Finnish mineworkers looked to the Western Federation of Mineworkers (WFM) union for support to continue the strike, but the WFM (now a part of the IWW) had its own problems. The WFM lacked funding to support a prolonged strike and received no support from the much larger craft union organization, the American Federation of Labor (AFL). The AFL's disassociation from the WFM was

\footnotetext{
${ }^{132}$ Karni, "The Founding of the Finnish Socialist Federation,” 65-70.

133 Passi, "Finnish Immigrants and the Radical Response," 121.

${ }^{134}$ Auvo Kostianen, "The Forging of Finnish-American Communism, 1917-1924: A Study in Ethnic Radicalism," Turun Yliopiston Julkaisuja,Annales Universitatis Turkuensis,,series ed. Sarja B, Humaniora, (Turku, Finland: Turun Yliopisto, 1978), 25, 38.
} 
due to the WFM and IWW's perceived radical organizational tactics. The AFL was also at ideological odds with the WFM and IWW on the practice of dual unionism, or members belonging to two unions at the same time as well as the practice of extending union membership to unskilled immigrant labor. The 1907 Strike ran out of momentum in the rank-and-file of immigrant mineworkers, did not receive anticipated funding from the WFM, and met overwhelming opposition from the Oliver Iron Mining Company (OIMC). These set-backs surreptitiously broke the strike and as the dissertation has already demonstrated, hundreds of Finnish immigrant mineworkers were blacklisted from employment on the Mesabi and Vermilion Iron Ranges. ${ }^{135}$

The relatively young FSF was rapidly learning the "hard lessons of the School of Morgan and Rockefeller." 136 Disillusioned Finnish immigrant socialists began to doubt the current course of the FSF. The Oliver had not met any of the WFM's demands in the 1907 Strike, the death rate of mineworkers on the Mesabi Range between 1905-1906 was high at 7.5 workers for every 1,000 workers, mine guards had shot five Finnish mineworkers between 1888 and 1905, and the WFM's leadership failed in efforts to organize the rank-and-file mineworkers. Members of the FSF who were partial to the IWW's revolutionary industrial unionism began to agitate for a more militant organization. Adding to the problems with the WFM leadership, Finnish strikers began to feel that the WFM's leaders exploited immigrant strikers. As Finnish immigrant strikers suffered to put bread on the table during the strike, the WFM's organizers, such as Teofilo Petriella, were reportedly living lavishly. Ethnic rivalry and suspicion had played

${ }^{135}$ Pinola, "Labor and Politics," 25-28.

${ }^{136}$ Karni, "The Forging of the Finnish Socialist Federation," 82. 
a major role in organizing difficulties and blacklisted, sometimes bitter Finnish immigrant mineworkers resorted to farming marginal lands in northern Minnesota's turbulent hinterlands just to put food on the table. ${ }^{137}$

The events of the 1907 Strike fostered feelings of discontent within the FSF, setting the stage for an important ideological split in the organization. The division was between a growing number of the FSF members who advocated direct action, revolutionary goals (Red Finns), and the parliamentary, reform element of the Socialist Finns (Yellow Finns). ${ }^{138}$ The 1907 Strike's difficulties occasioned a momentous debate at the 1909 FSF convention. The Yellow Finns, known as “Opportunists,” passed a resolution condemning anarcho-syndicalist methods. The Red Finns, known as the "Impossibilists," argued for industrial, "One Big Union" representation and the right to impose direct action through strikes. The Impossibilists saw politics as a tool for the bourgeoisie, while the Opportunists saw politics as a tool for change. ${ }^{139}$ Debate over the FSF's future colored the proceedings of the FSF from 1909 to 1914, when a final split in the competing ideologies occurred after the bitter and bloody 1913-1914 Michigan Copper Strike. Much of the debate between 1909 and 1914 took place within the walls of the Work Peoples' College (WPC) and the efforts to create a class-conscious pedagogy reflected the terse interactions between the Impossibilists and Opportunists.

As Finns were arriving and becoming social, intersectional actors in the United States during the early $20^{\text {th }}$ century, a host of socialist or labor colleges were springing up

\footnotetext{
${ }^{137}$ Pinola, "Labor and Politics," 26-28.

${ }^{138}$ Passi, "Finnish Immigrants and the Radical Response," 16.

${ }^{139}$ Douglas J. Ollila, Jr., "From Socialism to Industrial Unionism," in The Finnish Experience in the Western Great Lakes Region, (Turku, Finland: Institute for Migration, 1975), 159.
} 
in the United States, such as the Peoples' College in Fort Scott, Kansas, which was founded in 1915, and the Brookwood Labor College, founded Katonah, New York, in 1921. However, the FSF and immigrant Finns were ahead of the "game" in many aspects, as the WPC was a precursor to many of these labor colleges. Founded in 1907 in Smithville, Minnesota, (now within Duluth, Minnesota's boundaries), the WPC's proletarian curriculum was heavily influenced by the IWW's ideology. The WPC was a center of proletarian education that based its curriculum around a "propaganda of the deed" or direct action ideology. The school was a bastion of socialist and industrial unionist thought, with many of the professors teaching direct action tactics such as industrial sabotage.

\section{The 3Rs of Proletarian Literacy}

The WPC was not just teaching the "two Rs" of reading and (w)riting, but rather was working to educate in the 3Rs of proletarian literacy: reading, (w)riting, and revolution. The goal was to create an identity for the college, its students, and its faculty that stressed the development of class-conscious workers who were familiar with the theoretical basis for industrial unionism and the cultural apparatus to translate that ideology to illiterate or semi-literate immigrants and the children of immigrant workers. This separated the literacy program of the WPC from other general literacy programs; it was not just about the mechanics of reading and writing; it was ultimately about reading and writing as a way to break the bonds of repressive institutional hierarchies such as religion, statism, and most significantly_capitalism. Thus, the literacy aimed at in the WPC was so much more than a basic literacy. It went deeper than that. The literacy gained at the WPC was a cultural, class, and philosophical competency in working-class 
movements and ideology. As imagined, this revolutionary approach to a program of literacy met with great opposition in many reactionary, liberal, and even progressive circles. While the WPC did offer courses on Marx and scientific socialism, for the most part the College's curriculum centered on industrial unionism and propaganda of the deed. It was a very radical curriculum, much like Francisco Ferrer's earlier anarchistinspired Escuela Moderna for traditionally aged primary school students in Spain, which fomented later iterations of that pedagogical background in the United States' own Modern School movement.

The WPC, however, focused on adult and continuing education, though it did offer summer school to children of working class adults. Though proletarian literacy was the desired outcome, early on it became apparent that a need for basic literacy programs was needed due to the lack of formal education among the WPC's students. As historian Richard J. Altenbaugh wrote, "The rudiments of mathematics and the basic rules of Finnish grammar had to be taught to worker-students who, although literate, came from poor rural backgrounds in Finland, which required a minimal amount of formal schooling." ${ }^{140}$ The need for basic forms of education was very apparent early in the school's history. As Finnish American historian Douglas Ollila, Jr. detailed:

Of the 123 students enrolled in 1911-1912, forty had had no previous education whatsoever, while fifty-seven had had at most two years of training in the elementary schools of Finland. The educational level of the Finnish immigrant was thus quite low, in contrast to the stereotype that Finns had attained a high

\footnotetext{
${ }^{140}$ Richard J. Altenbaugh, Education for Struggle: The American Labor Colleges of the 1920s and 1930s, (Philadelphia: Temple University Press, 1990), 99.
} 
educational level in Finland. It is interesting to note that the need to master basic educational skills was so imperative that the college founded a correspondence school whose chief aim was lessons in English. ${ }^{141}$

Courses in basic literacy, then, were accompanied by accounting, mathematics, and science courses in Finnish and sometimes English, which supplemented highly didactic coursework centered on the cultivation of the 3 Rs.

The WPC had a somewhat tempestuous early existence, because for a time it mirrored the split in the Finnish immigrant's divided labor and proletarian political movement. In its early years, the school teetered between parliamentary socialism and industrial unionism (some might opine anarcho-syndicalism), but as Ollila wrote, "at the 1909 meeting of the Finnish Socialist Federation, industrial unionism and especially the IWW were condemned as being anarchistic, but radicalism persisted in the Midwest, especially at the school." ${ }^{142}$ The WPC was decidedly a young adult, or older, oriented institution aimed at general education as well as educating labor agitators and organizers for work in the field. Professors were generally older and battle-hardened Finnish immigrants associated with the labor movement, such as Leo Laukki, Yrjö Sirola, and Fred Jaakkola, but the institution itself was home to young proletarians looking to shape the world, starting with the Lake Superior region, into a more equitable place. For many

\footnotetext{
${ }^{141}$ Douglas J. Ollila, Jr., "The Work People's College: Immigrant Education for Adjustment and Solidarity," in For the Common Good: Finnish Immigrants and the Radical Response to Industrial America, edited by Michael Karni. (Superior, Wisc.: Työmies Society, 1977), 105-106.

${ }^{142}$ Ibid., 103.
} 
twenty-somethings at the WPC, it was likely a great place to be young, passionate, and radical.

And, it was these radical, revolutionary topics that dominated the college's curriculum as various forms of socialism and industrial unionism were taught. As Ollila, Jr. wrote:

While basic education was a primary aim, nevertheless a good many students absorbed socialism in a greater or lesser degree. For many, it was perhaps a very superficial mastery of the theoretical ideas of Marx, Engels, and Kautsky. No doubt the most important learning which took place could be described as "experiential" in the sense of emotional commitment, comradeship, and a faith that "the world would soon be ours."143

The college took a further radical swing to the left when the faculty and students began to advocate the ideology of anarchist philosophers and implement propaganda of the deed curriculum. The turn toward anarcho-syndicalism did not go unnoticed by the parliamentary elements of the Finnish immigrant socialist community, "Alarm was expressed when Haywood and Bohn's text, Industrial Socialism, was made a standard textbook for classes, and when students had concluded at a 'tactics' session that the MacNamara dynamiting episode had been of benefit to the socialist movement because it showed the poverty of craft unionism."144

This radical curriculum found a willing audience as enrollment numbers consistently hovered above 100 students during the 1910s, reaching a high of 157

\footnotetext{
${ }^{143}$ Ollila, Jr., "Work Peoples' College," 106.

${ }^{144}$ Ibid., 107.
} 
students during the 1913-14 school year. This high-water mark in the early 1910s was the upward swing, as the fractioning of the FSF after the 1913-14 Copper Strike in Michigan's Upper Peninsula and the repressive social measures of the World War I and Palmer Red Scare eras made the college's existence fleeting at best. The WPC survived the repressive era after World War I but did so with a pronounced institutional limp. Official affiliation with the IWW brought recognition, but this recognition never really translated into increased student numbers or for that matter increased enrollment of nonFinnish background students. ${ }^{145}$

\section{Examples of Proletarian Literacy}

The importance of multiple media formats in advancing the cause of proletarian education and literacy cannot be understated. Efforts concerned with the promotion of literacy in the movement, the WPC, and the immigrant population were done primarily via print media and in more popular culture media, by song. Print media, however, was an incredibly important tool for working class literacy and educational programs, so much so that the WPC even advertised for their correspondence school in a Finnish language IWW-affiliated newspaper. A delve into the primary sources regarding the literacy programs of the WPC, and for that matter the IWW, illustrates multi-modal, multiple format attempts to create a literate Finnish immigrant working-class. The WPC was rich with what we might call today, material culture (discussed further in Chapter 6). The school and its supporting media outlet, the Workers' Socialist Publishing Company (WSPC), cranked out a broad array of publications that brought the printed word,

\footnotetext{
${ }^{145}$ Ibid., 110-113.
} 
cartoons, and photographs of industrial union-themed topics to the student body and faculty of the WPC, but also to the larger Finnish immigrant community.

The WPC housed its own publishing company on the college's campus in Smithville as a sort of practical training ground for future cartoonists, editors, journalists, and press and typesetting operators. This faculty and student run press printed numerous titles, but the astutely titled periodical Ahjo (The Forge), which discussed current issues in industrial unionism, official IWW business, and was a forum for student-generated essays, prose, and poetry, was the most important means of increasing literacy efforts at the WPC. There simply was no better way to encourage ascending levels of literacy in both reading and writing than to have a place for students to submit and read the fruits of their proletarian education.

The WSPC, also located in Duluth, published companion print media that promoted the college, but also the industrial union movement and the IWW in general. The WSPC was a fully-fledged publishing company complete with a newspaper, which underwent several name changes that reflected strengthening ties with the IWW between 1914 and 1917. In 1915, when the newspaper split from the FSF's official media offering, Työmies (The Working Man), the WSPC chose to title the newspaper Sosialisti (The Socialist), which indicated its undecided official ideology. Little more than a year later, the publishing company changed the name of the newspaper to Teollisuustyöläinen (The Industrial Worker), indicating a commitment to industrial unionism in general. By 1917, the paper underwent its last name change, a name that stood until the mid-1970s when the paper folded due to declining readership. This new title, Industrialisti (The Industrialist), indicated full support and affiliation with the IWW, which had great implications for the 
industrial union movement in the Finnish immigrant population and within the walls of the college. ${ }^{146}$ Additionally, by 1929 , the WSPC began printing its own periodical Tie Vapauteen (The Road to Freedom), which was a monthly look at IWW issues, literature, and of course, industrial unionism. Published in a magazine format, Tie Vapauteen's lavish cover art was a monthly celebration and exhibition of proletarian-inspired creativity.

The WSPC also printed numerous monographs associated with industrial unionism. On hand from past association with the FSF were previous tracts on anarchosyndicalist philosophy such as the work of significant anarchist philosopher Peter Kropotkin. While still unified, the FSF published a Finnish-language translation of Kropotkin's Taistelu Leivästä (The Conquest of Bread) before 1914. This translation was one important step in creating the proletarian philosophical literacy so strongly needed to educate and engage class-conscious Finnish immigrant workers. After the schism in the FSF, the WSPC began its own publishing campaign to highlight authors associated with the IWW and revolutionary unionism.

While the IWW did not recognize the Finnish immigrant population as a separate ethnic organization within its ranks, the IWW certainly did print numerous agitation and organization materials in the Finnish language. One such offering was the TeollisuusUnionismin Opas (The Industrial Unionism Guidebook) published by the IWW for the Metal Mine Workers Industrial Union 490 in Virginia, Minnesota. This publication carried the official IWW logo, acted as an introduction to the union, and suggested that

\footnotetext{
${ }^{146}$ Gary Kaunonen, Challenge Accepted: A Finnish Immigrant Response to Industrial America in Michigan's Copper Country, (Lansing, Mich.: Michigan State University Press, 2010), 189. 
"For further information, if desired, write the IWW secretary WM D. Haywood 307164 W. Washington St., Chicago, ILL." 147

Another title from the WSPC provided an intimate look at just what the industrial union movement's education and literacy campaigns demanded from would be devotees. Nuoriso, Oppi ja Työ (Youth, Learning and Labor), is a truly unique publication because it was bi-lingual. The first section of the book was printed in Finnish and the latter half in English. The English section of the book contains a very exclusive glimpse of what was important to the cultural, historical, and philosophical literacy of Finnish immigrant and Finnish American industrial unionists. The first part of the second half of the book contains an English language account of human history from the evolution of life and "man," a short history of black slavery, an introduction to wage-slavery, a discussion of feudalism and capitalism, the fight for public schools, and a condensed history of the American labor movement. The short, whirlwind history of humanity leads to a detailed discussion of the IWW and the merits of industrial unionism, the differences between syndicalism and industrial unionism, and the misrepresentations of direct-action tactics. $^{148}$

This wrestling between ideological terminologies was a theme that dominated the IWW's English-language publications as well. The distinction between anarchosyndicalism and industrial unionism was an important one and one that could be easily misunderstood by rank-and-filers. The distinction between competing unionisms was

\footnotetext{
${ }^{147}$ Industrial Workers of the World, Teollisuus-Unionismin Opas, $3^{\text {rd }}$ printing, (Virginia, Minn.: Quick Print, n.d.), back cover.

${ }^{148}$ Wm. Rein, Nuoriso, Oppi ja Tyo (Youth, Learning and Labor), (Duluth, Minn.: The Workers' Socialist Publishing Company, 1929), 118.
} 
opaque philosophical material, but the book took the time to address the differences and make readers literate in the terminology and dialogue of IWW issues:

Modern industrial unionism is not syndicalism, as it is no "syndicate" or federation of old craft unions. Its construction and scope of action are entirely different from those of the craft unions and different from all political and nonpolitical parties...No old form of labor union can be made to fit the entirely new conditions in production; and no mere change of ideals, no matter how radical, can possibly make them conform to the new conditions. The entire structure and scope of action of the labor organizations must change...It [the IWW] is by no means perfect, but it has a mighty good outline and a firm basis upon which to stand and develop. ${ }^{149}$

The texts printed by the WSPC were certainly an assertion of ideology, but they were also a statement of identity. These books, magazines, newspapers, and pamphlets let readers know what it meant to be a member of the IWW and how membership in the union differed from other organizations. Toward this end, many IWW media outlets reprinted the union's preamble, a definitive statement of identity, which was adopted at the union's founding conference in Chicago in 1905. Literally, the preamble spelled out the aspects of an IWW sanctioned working-class identity, prescriptions for revolutionary union activity, and how the Wobblies' sense of a collective self differed from that of the bosses:

${ }^{149}$ Ibid., 119. 
The working class and the employing class have nothing in common. There can be no peace so long as hunger and want are found among the millions of working people and the few who make up the employing class have all the good things in life.

Between these two classes a struggle must go on until the workers of the world organize as a class, take possession of the earth and the machinery of production, and abolish the wage system. ${ }^{150}$

The IWW's preamble was a straightforward assertion of intentions, but the union took its proletarian literacy a step further when they produced a heuristic dialogue to explain the ideological and philosophical foundations of the preamble and industrial unionism. In a booklet titled, What is the I.W.W. Preamble?, two characters identified as, "Bob Hammond, a laborer, hardworked, but anxious to know," and "Henry Tichenor, a technical engineer, his boyhood friend, eager to tell," talk about all things IWW, including the importance of the preamble. While the dialogue is somewhat formulaic and outdated by contemporary standards, the rather plain, folksy tone and friendly manner used by the characters is likely an attempt to mediate the rough image and violent portrayal of the IWW in reactionary media of the era. In one section titled, "Wages Vs. Profits," the dialogue reads:

Tichenor (amazed):... What are all these conflicts, if not manifestations of the antagonistic interests of capitalists and laborers? What do they prove, if not the truth of the statement that, "the working class and the employing class have

\footnotetext{
${ }^{150}$ Ibid., 123.
} 
nothing in common"?

Hammond (puzzled): Well, I guess you are right. There is no getting 'round those facts. They show a wide, impassable gulf. But, how comes it that, despite all that, employers inaugurate welfare departments and workers' republics, and give the workers the privledge to buy shares? Surely, they are looking after the workers and giving them something in common.

Tichenor (uproariously): Say, those are all methods to keep the workers docile, underpaid and unorganized. Welfare departments are cheaper than union wages and union control. They are also paternalistic... ${ }^{151}$

The IWW's assertions of identity and ideology were likely music to the ears of many young, disaffected, and disenfranchised children of Finnish immigrant laborers, as well as their American Fellow Workers. Not only was it likely music to working-class ears, but the IWW had music for their actions as well. Perhaps the most cherished of all IWW publications was the oft-memorialized and popularly known Little Red Songbook, which was officially titled, IWW Songs: To Fan the Flames of Discontent. This songbook was an ever present feature of the IWW's cultural activities and was an essential component to the process of crafting literacy in the working-class. Even if a worker could not read, once memorized the songs of the IWW gave them an opportunity, at the very least, to understand the basics of industrial unionism. Added to this was the fact that many IWW songs had familiar melodies, even old religious tunes, with lyrics crafted specifically to fit the industrial wageworker's milieu. An especially popular song was

\footnotetext{
${ }^{151}$ Industrial Workers of the World, What is the I.W.W. Preamble? A Dialogue, $4^{\text {th }}$ printing, (Chicago: Department of Education, Agricultural Workers Industrial Union, 1923), 11-12.
} 
"Dump the Bosses Off Your Back," written by John Brill and sung to the tune of "Take it to the Lord in Prayer":

Are you poor, forlorn and hungry?

Are there lots of things you lack?

Is your life made up of misery?

Then dump the bosses off your back.

Are your clothes all patched and tattered?

Are you living in a shack?

Would you have your troubles scattered?

Then dump the bosses off your back.

Are you almost split asunder?

Loaded like a long-eared jack?

Boob-why don't you buck like thunder?

And dump the bosses off your back.

All the agonies you suffer,

You could end with one good whack-

Stiffen up you orn'ry duffer-

And dump the bosses off your back. ${ }^{152}$

Along with popular IWW songs, the union used images and cartoons to educate.

The IWW adroitly used images to reach working-class individuals who were illiterate or

${ }^{152}$ Industrial Workers of the World, IWW Songs: To Fan the Flames of Discontent, Joe Hill Memorial Edition, (Cleveland: I.W.W. Publishing Bureau, n.d.), 38. 
those who could not read or speak the English-language. The IWW's visual depictions of class struggle were perhaps most important for its attempts at organizing immigrant workers who understood little or no English. Additionally, images were a sort of quick and dirty ideological summation for those who could not spend long hours reading philosophical tracts or IWW preamble dialogues. These two media formats, IWW songs and cartoons, are perhaps the most ingenious iterations of the crafting of proletarian literacy. Ingenious because the use of previously known tunes to accompany songs, vivid proletarian imagery, and common themes in pop culture to educate workers about their own plight helped the IWW appeal to those who wanted to become class-conscious, but did not have the class background to attend institutions of formalized education. The IWW's multi-modal literacy efforts were designed to appeal to the masses. This type of dissemination of educational and literacy information formats meant that an industrial worker did not have to read to become fluent in class-consciousness—one could get the general idea from a song or an image and develop a proletarian literacy.

For Finnish immigrants, many of whom were at the very least semi-literate in the home language, the production of the varied forms of media gave Finns multiple and intersectional opportunities for engagement with responses to American capital, an identity that included being a part of the American working-class, and the occasion to improve upon their own class-conscious literacy. Thus, these immigrants were not only being presented the fundamentals of reading or writing, whether in the Finnish language or in the English language, but were also extended an invitation to become a part of the greater American working class. For immigrants, IWW media was cultural, economic, and social class immersion in an adopted homeland. 
The IWW and Finnish immigrant Wobblies understood that literacy is not simply about reading and writing; social contexts for illiteracy are perhaps more pronounced if the underlying social problems are not included in an analysis of illiteracy. Hand-in-hand with efforts to stomp out illiteracy were grassroots programs that explained the socioeconomic causes of illiteracy. As the IWW and Finnish immigrant Wobblies understood, the "theory" of stomping out illiteracy is great, but the roots of illiteracy are not theoretical; they have institutional and tangible forms that must be understood first by those enacting literacy programs and then by those striving to become literate. Part of the struggle to organize workers on Minnesota's Iron Ranges was to craft a sort of classconscious literacy and the training of Finnish immigrant Wobblies was a central part of this fight.

This goal of this chapter was to highlight the formation of working-class identity through literacy and educational efforts by the IWW and within the Finnish immigrant population. Once such working-class identities were developed, ideological imperatives were better understood in the context of what it meant to be a Wobbly, both from a personal perspective and also from a social standpoint. The upcoming chapter will examine the intersections between identity and ideology, examining an ideological construct that was controversial both for members of the IWW and for the public at large. The advocacy of sabotage as a weapon in the class struggle was a hotly debated issue in IWW circles. This promotion also plagued the union's public image as the United States government and American capital decried the tactic as an un-American, destructive measure aimed at crippling the national economy. 


\section{Chapter 4:}

\section{Stoking the Ideological Fires-Sabotage, Organized Labor, and the Oliver}

\section{Chapter Introduction: Sabotage as an Ideological Construct}

As efforts at creating an educated, class-conscious working population on Minnesota's Iron Range began to flourish, immediate resistance to these efforts came from industry. For mineworkers on the Iron Ranges, the most stalwart and well-heeled resistance came from the Oliver Iron Mining Company (OIMC or Oliver). There were other mining companies on the Range: Hanna, Pickands-Mather, International Harvester, and a host of smaller corporations, but Oliver had the might to wield a powerful hand in influencing the Ranges' economics, culture, and politics. Here-in lies the great underdog story-there was a David and a Goliath on the Range_ - and any attempt to organize workers was going to be an epic battle waged, literally, from the iron ore pit, up.

The 1916 Strike did not materialize from the ether and the tactics used by the IWW to combat those used by the Oliver, such as the blacklist, intimidation, and violence, were not invented in 1916. One of the IWW's most effective, yet controversial tactics against industrial employers was sabotage. Issues relating to sabotage on the Minnesota Iron Ranges were central to workers. The iron mining companies owned the mines, machinery, and mills. Even the roofs over mineworkers' heads were most often owned by the mining companies. Moreover, mining companies heavily influenced most of the Iron Range's educational, political, and social landscape, in addition to owning the actual physical landscape. Most workers owned nothing but their labor and combatting the lock, stock, and barrel ownership of resources on the Iron Range was a key part of the 
1916 Strike. Sabotage was one accessible tactic that could effectively checkmate such lopsided power relations.

This chapter will explain the history of industrial sabotage and analyze how the IWW navigated internal discussions and rancor over its meaning and use. The utilization of sabotage as a weapon in the class war was provocative to the public at-large, but also within the IWW. Ultimately, sabotage became an ideological construct and a term that came to define what it meant to be a member of the IWW. Fairly or not, sabotage became a part of the IWW's identity. What sabotage was, how it should be used, and if it was an acceptable form of class struggle were commonly debated questions by the IWW's leadership. The question and use of sabotage made its way into treatises and pamphlets, and even into Wobbly popular culture. Industrial sabotage, be it a conscious withdrawal of efficiency on the job or outright destruction of company property, came to be an enduring symbol of the IWW's primary ideology—direct action at the point of production.

\section{Industrial Sabotage: A Short Ideological Machine-breaking History}

Historical recollections of early industrial machine breakers such as the French Sabots, who reportedly threw their wooden shoes in machines to halt production, became a celebrated, poetic representation of the class struggle to many Wobblies:

If Freedom's road seems rough and hard,

And strewn with rocks and thorns,

Then put your wooden shoes on, pard,

And you won't hurt your corns.

To organize and teach, no doubt, 


$$
\text { Is very good-that's true, }
$$

But we still can't succeed without

$$
\text { The Good Old Wooden Shoe. }{ }^{153}
$$

The "Good Old Wooden Shoe" was action. It was what philosophers might describe as praxis or a "doing" to all the theoretical machinations of industrial unionist rhetoric. In tracing the origins of praxis in organized labor, it is perhaps necessary to identify the ideological roots of the term as defined by Marx in his Theses on Feurerbach, where he wrote:

The main defect of all hitherto-existing materialism... are conceived only in the form of the object, or of contemplation, but not as human sensuous activity, practice [praxis] not subjectively. Hence it happened that the active side, in opposition to materialism, was developed by idealism—but only abstractly, since, of course, idealism does not know real, sensuous activity as such. ${ }^{154}$ The IWW's advocacy of direct action can be ideologically linked to Marx, but the IWW's call to action was not philosophical or theoretical—it was a physical or material assault on the control of the employing class. Defined as such, praxis moves this chapter from European theoretical works by Marx, to IWW organizer Elizabeth Gurley Flynn's written advocacy for action in pamphlets printed by the IWW and Workers' Socialist Publishing Company in far-off Duluth, Minnesota. These distilled philosophies on praxis and direct action made it into the hands of striking workers on Minnesota's Iron Ranges.

\footnotetext{
153 Joe Hill, "The Good Old Wooden Shoe," in I.W.W. Songs: To Fan the Flames of Discontent, Joe Hill Memorial Edition, (Cleveland, Ohio: I.W.W. Publishing Bureau, n.d.), 51.

${ }^{154}$ Marx, Theses on Feuerbach, 1845.
} 
And, if they were in the hands of workers, these strategies of direct action were also in the hands of mining company management, thanks to industrial spies.

Thus, the ideological underpinnings for a revolutionary movement against economic, social, and even more-so technological control in the Iron Ranges' workplaces was loosed on Minnesota's Iron Ranges for all to see. However, while Marx provided a theoretical argument for praxis, there was left to be elucidated a practical mechanism to employ the actual performance of workplace disobedience and resistance. For this, the actions and writings of Russian anarchist Mikhail Bakunin, and the implementation of extra-parliamentary direct action or what Bakunin termed "propaganda of the deed," become necessary to understand the IWWs implementation of direct action ideology in the workplace. By engaging the "bosses" in the industrial workplace, employees were seeking some type of localized control over the machinery they were working with in order to create a more democratic working environment and thus a more egalitarian and democratic industrial society. For the IWW, the choice to engage bosses with sabotage provided a duality of the deed that acted not only on the physical artifact or machine, but also on the socio-economic and political apparatuses that exploited workers in industrial society. While the struggle by industrial workers against control in the workplace has received high-minded theoretical considerations from influential thinkers, it was direct action that ultimately implemented any ideology or theory and the balance of this chapter seeks to chronicle a history of actual physical defiance regarding control of industrial relations in workplaces, and specifically in the Lake Superior basin's mining industry during the early $20^{\text {th }}$ century. 
Direct action responses to such control have not received their due attention in labor history, labor studies, or American studies. Perhaps this is because control in the workplace is almost exclusively an issue of class, a topic that is still somewhat taboo in America. Control in the workplace is almost exclusively about ownership of the means of production and the relationship to the means of production. In a workspace controlled by an "owner," the working-class has little control or ownership of anything except their labor, and as Andrew Feenberg writes, "[Marx] claimed that we will remain disenfranchised and alienated so long as we have no say in industrial decision-making. Democracy must be extended from the political domain into the world of work." While Feenberg often quotes Marx in his work, he also acknowledges the limits of the MarxistEngelian critique of technology and posits another view of radical change in the workplace when he writes:

We are not dealing here with a mere critique of the property system, but have extended the force of that critique down into the technical "base." This approach goes well beyond the old economic distinction between capitalism and socialism, market and plan. Instead, one arrives at a very different distinction between societies in which power rests on the technical mediation of social activities and those that democratize technical control and, correspondingly, technological design. $^{155}$

\footnotetext{
${ }^{155}$ Andrew Feenberg, "Democratic Rationalization: Technology, Power, and Freedom," in Philosophy of Technology: The Technological Condition, An Anthology, eds. Robert C. Scharff and Val Dusek, (Malden, Mass.: Blackwell Publishing, 2003), 658.
} 
Control in the workplace becomes an issue of how an object, person, or time is used, and for what purpose. Industrial technology, or the application of science for practical purposes in industry, acts as a mechanism of control on workers through scientific management, speed-ups, and introduction of "labor saving" machinery. And, as Chellis Glendinning argues, technology consists of more than physical machinery; it is a worldview that can be characterized as a "mechanistic" approach to life. Values of productivity, progress, and detachment from humanist ethics typify such a technologically controlled society. Additionally, Langdon Winner, one of the most noted voices of technological critique writes that "one major shortcoming in the technologies of the modern period is that those touched by their presence have little or no control over their design or operation. To as great an extent as possible, then, the processes of technological planning, construction, and control ought to be opened to those destined to experience the final products and full range of social consequences." ${ }^{156}$ Feenberg, Glendinning, and Winner offer interesting contemporary critiques of control in modern and historical industry, and society, but fall short in giving practical application to their somewhat complex theoretical structures. For practical application of defiance of technological control in the work place, we must step back into history to examine physical confrontations with control in the workplace.

The history of industrial sabotage, which was the most effective way of combating workplace and technological control by a nascent capitalist class, is as old as

\footnotetext{
${ }^{156}$ Landgon Winner, "Luddism as Epistemology," in Philosophy of Technology: The Technological Condition, An Anthology, eds. Robert C. Scharff and Val Dusek, (Malden, Mass.: Blackwell Publishing, 2003), 606.
} 
the industrial machine itself. "Sabotage" as a term comes from the French sabot, which referred to the wooden clogs or shoes worn by peasants in the French countryside. These peasants were the workers who filled French factories in the burgeoning industrial revolution of the 1800s. But, when workers in Lyons initiated a revolt in the silk spinning factories due to starvation wages in periods of slow production, the term "saboteur" became affixed with the movement of peasants to engage in direct action to better their working conditions. ${ }^{157}$

Industrial sabotage was perhaps most famously known as a tactic used by English mill workers as part of the Luddite movement, which saw workers destroy the means of production across the English countryside. The first such incident occurred on a Sunday in April, 1812, and as Kirkpatrick Sale describes, "a band of some six score Yorkshiremen" set to destroying the mill of hated industrialist William Cartwright. This action led to a rash of incidents of industrial sabotage and the practice caught on across the British Isles as a means of combating the displacement of manual labor by machinery in this early period of industrial development. The Luddite movement became a direct refutation of industrial technology and the control such technology imparted to factory owners, manufacturers, and industrialists. ${ }^{158}$

As a definable strategy to subvert industrial efficiency, sabotage became a tactic used by Scottish dock workers in the late 1800s, and was referred to as, "Go Cannie," in Scots Gaelic or in English, "Go slow." After a strike by dock workers in Glasgow, in

\footnotetext{
${ }^{157}$ Emile Pouget, Sabotage, translated from the French with introduction by Arturo Giovannitti, (Chicago: Charles H. Kerr and Company, 1913), 37-41.

${ }^{158}$ Kirkpatrick Sale, Rebels Against the Future: The Luddites and their War on the Industrial Revolution, (Cambridge, Mass.: Perseus Publishing, 1996), 7-9.
} 
which the workers asked for a two-cent raise, the practical application of ideology resulted in a tactic of implementing bad work for bad wages. This direct action swept across the British Isles and made its way to the European Continent in a matter of weeks. $^{159}$

In these early manifestations of sabotage the basic formations of direct action concepts applied to industrial exploitation and hegemonic control of industrial technology are demonstrated: so long as the industrial worker was disenfranchised from control regarding industrial labor and working conditions, the machinery would either be slowed or would not run. This tactic was not only practical, but also highly effective and became one of the most successful and feared weapons of class struggle. Sabotage hit employers in their pockets, directly affecting socio-economic relations.

\section{The IWW and Sabotage}

In perhaps its most significant, if not notorious manifestation in the United States, the Wobblies came to be associated with industrial sabotage. As part of the industrial union's direct action ideology, industrial sabotage came to be a steadfast tactic used in combating the technological control corporations and industry claimed over their workforce. Throughout the IWW's history there has been an on-going debate over the acceptable measures and uses of industrial sabotage, and what in fact the term means in class struggle, and in more practical terms, what sabotage means in the field of industrial agitation and organization.

\footnotetext{
${ }^{159}$ Pouget, Sabotage, 41-44.
} 
Some early manifestations of the IWW's brand of industrial sabotage closely mirrored that of the Luddites. The union came under scrutiny from all directions for their endorsement of industrial sabotage. In 1913, and continuing the rancor over direct action that began during the First International, the Socialist Party of America formally voted to "adopt a new enactment under which anybody advocating crime, sabotage, or violence as aids in the emancipation of the working class shall be expelled from the party." 160 This refutation of direct action by the Socialist Party of America pushed the marginalized proponents of sabotage out of the party and led to a splintered labor movement in early $20^{\text {th }}$ century America.

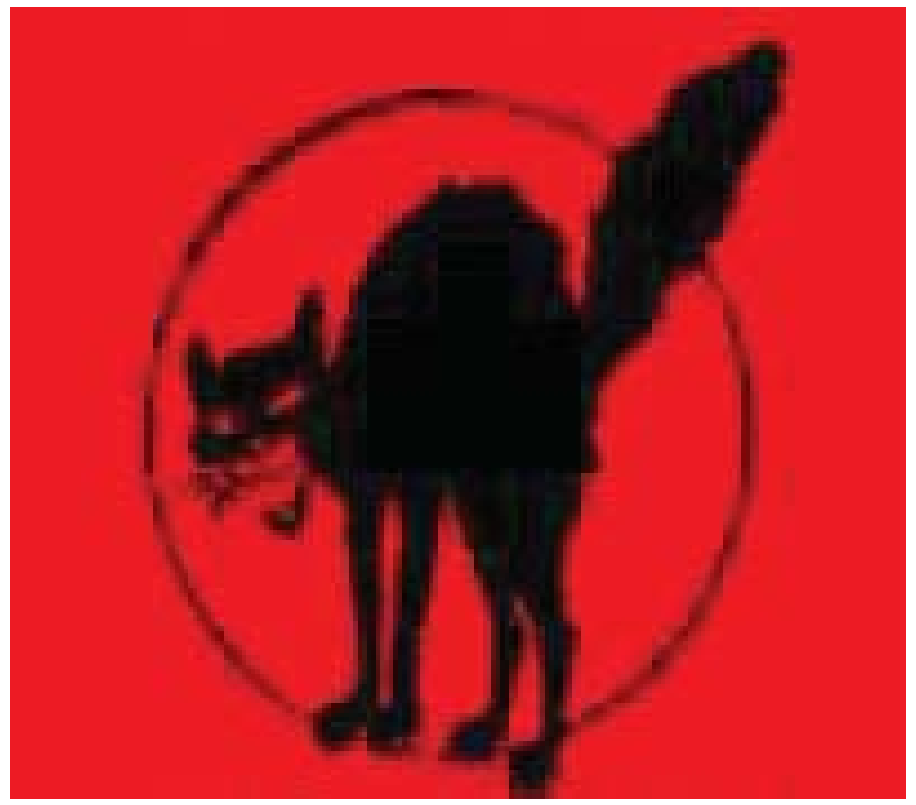

Figure 4.1-Common representation of Sabo Tabby in IWW literature-from www.iww.org

However, the IWW did not give up on the concept of sabotage and this advocacy landed around 166 Wobblies in prison in 1917. The group, in fact, adopted an artistic

\footnotetext{
${ }^{160}$ Moses Oppenheimer, "Direct Action and Sabotage," in The New Review, Vol. 1, No. 4, New York,
} $1913,113$. 
animal representation to bolster the practice. The birth of "Sabo Tabby," an arched-back, screeching black cat image gave caricature to the movement and application of direct action tactics in the industrial workplace. The consternation over sabotage as an effective form of class struggle colored the IWW's intra-union debates. Talented Wobbly organizers such as Elizabeth Gurley Flynn and Walker C. Smith advocated the use of sabotage in industry but specified very different applications of the idea to combat control in the workplace. Flynn wrote of the practice:

Sabotage means primarily: the withdrawal of efficiency. Sabotage means either to slacken up and interfere with the quantity, or to botch in your skill and interfere with the quality, of capitalist production or to give poor service. Sabotage is not physical violence, sabotage is an internal, industrial process. It is something that is fought out within the four walls of the shop. ${ }^{161}$

Smith wrote of the practice:

Sabotage is the destruction of profits to gain a definite, revolutionary, economic end. It has many forms. It may mean the damaging of raw materials destined for a scab factory or shop. It may mean the spoiling of a finished product. It may mean the displacement of parts of machinery or the disarrangement of a whole machine where that machine is the one upon which the other machines are dependent for material. It may mean working slow. It may mean poor work. It may mean missending packages, giving overweight to customers, pointing out defects in goods, using the best of materials where the employer desires adulteration, and

\footnotetext{
${ }^{161}$ Elizabeth Gurley Flynn, Sabotage: The Conscious Withdrawal of the Workers' Industrial Efficiency, http://www.iww.org/culture/library/sabotage, accessed March 10, 2010, October, 1916.
} 
also the telling of trade secrets. In fact, it has as many variations as there are different lines of work. ${ }^{162}$

A common area of agreement within the IWW was that sabotage was not designed to injure or harm human life or consumerism. Regardless of the IWW's advocacy for human life, to those in American industry, government, and even the Socialist Party of America, sabotage in any of its forms was an illegal and unproductive tactic. For the "bosses," possibly the most dangerous aspect of sabotage was that no matter how technologically advanced the industry saboteurs had an effective answer to combat the control of the employing class. By striking employers squarely in their pockets, sabotage rendered shiny, million-dollar machinery useless. Industrial sabotage was a method of direct action that registered a strong physical complaint toward employer control in the workplace; in a sense, via industrial sabotage, wageworkers were confidently stating to employers in no-uncertain terms, "There comes a time when the operation of the machine is so odious that you cannot even tacitly participate, you've got to place your bodies on the gears, the wheels, all the mechanisms, and you've got to indicate to those who own it, and those who run it, that unless you are free the machine will be prevented from working at all." 163

\footnotetext{
${ }^{162}$ Walker C. Smith, Sabotage: Its History, Philosophy, and Function, (Chicago: I.W.W. Publishing Bureau), n.d..

${ }^{163}$ U. Utah Phillips, "Unless You are Free," on Fellow Workers, (New York: Righteous Babe Records, 1999). Original quote used in the spoken word audio file seems to originate with Mario Savio's 1964 Sit-in Address on the Steps of Sproul Hall at University of California at Berkeley, www.americanrhetoric.com/speeches/mariosaviosproulhallsitin.htm.
} 


\section{Big Lake Labor Strikes as an Expression of Sabotage}

One of the more effective forms of sabotage was the massive withdrawal of efficiency — a strike — and this type of industrial sabotage was the most feared by employers. Mining companies on the Minnesota Iron Ranges shared this fear, but the 1916 Strike was not spurred on primarily by literature on industrial sabotage or especially vicious-looking portraits of the Sabo Tabby. Sabotage was merely one weapon in the class war. Rather, workers struck the OIMC and other mining companies on the Range because they felt exploited and wanted to change the material conditions of their labor and lives. So, while the IWW, its ideology, and its publishing may have been a guide toward the strike, it was the grassroots efforts of thousands of people over decades of time that brought about the passion and power of the 1916 Strike. The Strike, its proletarian energy, and tactics such as industrial sabotage were actually birthed in area ethnic halls, communicated through multi-language multi-modal media campaigns, gained identity in fraternal and benevolent societies, grew from class-conscious educational efforts, and learned from previous labor actions.

Though seemingly first advocated by the IWW, sabotage was well in place in the Lake Superior mining industry well before the invention of the Sabo Tabby. Lake Superior, the biggest of the Great Lakes, was one of the world's largest industrial regions producing the raw materials that fed copper smelters down the Great Lakes, produced the steel that propelled victory for Allied Forces in two world wars, employed tens of thousands of wageworkers, and hosted one of the most impressive accumulations of industrial machinery known to the human race. As may be imagined, along with this expensive machinery, corporate capital and control associated with such industrial 
development followed. As small-scale producers of copper and iron gave way to large corporate behemoths, industrial relations changed fundamentally with each passing year.

As the Lake Superior basin grew in industrial importance from the mid-1840s to the dawn of the new century, the battle for industrial democracy intensified. At first, small wildcat labor actions and walkouts announced the displeasure of workers with the "bosses," but as the output of copper and iron increased, so too increased the organization of wageworkers. From unions such as the Knights of Labor to the Western Federation of Mineworkers to the IWW, workers began to organize an effective response to industrial control of wages, working conditions, and technology. From the rather demure incantations of "talks" between labor and management in early disputes, more proactive and provocative methods towards the instillation of industrial democracy, such as those espoused by the IWW, came to color industrial relations in the Lake Superior basin. As the intensity and tactics of organized labor matured, the methods used by capitalists to increase efficiency through machinery, management, and monopoly also amplified. The stage was ultimately set for multiple clashes between labor and management regarding industrial democracy, and more specifically, control of the industrial workplace.

One such theater was in Michigan's Upper Peninsula. Signified by the region's moniker the "Copper Country," the Keweenaw Peninsula encompassed a spine of copperbearing rock, which gave birth to the mining industry that made the region famous. While extraction of copper from this region gave rise to a once prosperous industrial society beginning in the mid-1800s, the area has been in decline since the decades following World War II. In fact, today it is difficult to recognize the dwindling physical remnants of the booming, now bust copper industry. This decline does not, however, diminish the 160 
area's historical importance as a one-time producer of copper and home to one of the most impressive collections of industrial machinery and technology during that historic period.

It seems the historic industrial milieu in the Copper Country was perfectly set to foster multiple disputes between labor and management regarding technological control in the workplace. Sabotage as a form of protest with regard to technological control came to be associated with a number of workers' grievances in the area and though not associated with the IWW, early efforts at implementing industrial sabotage found willing participants in the Keweenaw's Copper Country as early as 1870. At this time, a company known as the Mabbs Brothers bought into a shipment of nitroglycerine oil and found few area mining companies willing to experiment with the unstable rock blasting agent. The Huron Mining Company decided to test the effectiveness of the oil and introduced it in their mine; the reaction to working with "nitro" in this early form was explosive, as a strike erupted with volatile consequences. As Copper Country sociotechnological historian Larry Lankton wrote:

Those mineworkers finally ended their standoff with Huron's management by blowing up the despised nitro. In the middle of the night, some mineworkers apparently, "got into the [storage] shanty, heaped the [black] powder from the keg around the glycerin, attached a long fuse, and the shock from the powder exploded the oil." Residents heard two explosions: one light, when the black powder detonated, and one very heavy, when the nitro went up. ${ }^{164}$

\footnotetext{
${ }^{164}$ Larry Lankton, Cradle to Grave: Life, Work, and Death at the Lake Superior Copper Mines, (New York: Oxford University Press, 1991), 95.
} 
Shifting across the Big Lake and west to Minnesota's Iron Ranges, strikes and the orchestrated withdrawal of efficiency became an essential way of showing displeasure with prevailing labor conditions. One such early labor action on the Minnesota Iron Ranges occurred on June 6, 1904, when 400 mineworkers walked out at the Drake and Stratton Stripping Operations of the Oliver's Fayal Mines in Eveleth, Minnesota, due to a pay decrease. Two striking mineworkers died in the clash, and set the tone for three years of tense labor relations with Finnish immigrants leading the challenge to company control of the workplace. ${ }^{165}$ The next skirmish between labor and management occurred on April 13, 1905, when a committee of unorganized mineworkers went before the Oliver's Superintendent of Mines. Mitchell refused to even hear the workers' demands, the workers struck, and two days later the OIMC ordered a general shutdown of its operations in an attempt to discipline labor through the loss of wages. This short, wildcat strike did not do much to advance the cause of organized labor, but those who were vociferous in their demands gained the agitator label and were placed on a regional blacklist. $^{166}$

Between 1905 and 1907, the WFM increasingly sent recruiters into the Ranges. By 1907, the WFM was successful in signing up approximately 2,500 mineworkers and was set to attempt a major labor action. ${ }^{167}$ This massive, conscious withdrawal of efficiency occurred on July 20, 1907, when Italian immigrant organizer Teofilo Petriella called out workers across the entire Mesabi Iron Range. ${ }^{168}$ The WFM, Petriella, and the

\footnotetext{
${ }^{165}$ Pinola, "Labor and Politics," 17-20.

${ }^{166}$ Ibid., 17-20.

${ }^{167}$ Karni, "The Founding of the Finnish Socialist Federation," 74.

${ }^{168}$ Pinola, "Labor and Politics," 20.
} 
mineworkers who followed them were branded by the company-kept press as immigrant radicals and anarchists for their fully reasoned, conscious withdrawal of efficiency. ${ }^{169}$ This tactic hit the pocketbook of the mining "bosses" hard and editorials in area newspapers that were partial to the company documented the success of the tactic, "[the strike parades of idle mineworkers were] a representative gathering of a class that wants this country run on the socialist plan, and who are willing to resort to all meaning of lawless acts [sabotage] to instill the reforms they seek." ${ }^{170}$ Because of the strike, not a shovel moved on the Mesabi Range and the 1907 Strike became the most massive and successful, up to that date, conscious withdrawal of efficiency in the Lake Superior region. Mining activity at the OIMC's mines had suddenly come to a standstill in Hibbing, Eveleth, and Virginia. The strike was so effective that to break the strike and increase production in the idled mines, the OIMC imported 1,100 Montenegrins and Croatians to take the place of striking mineworkers. The tactic of pitting working-class immigrants from different ethnicities against each other was a steadfast tactic used in the Lake Superior basin. The shuffling of low-wage, mostly immigrant employees to force striking workers back on the job or replace a workforce with new, unseasoned workers was a common response to worker grievances. ${ }^{171}$

From the 1907 Mesabi Strike to 1913, there was a tense labor peace across the Lake Superior basin. Flare ups in laboring populations occurred here and there, while labor agitation and organization occurred in earnest led mainly by socialist-unionist

\footnotetext{
${ }^{169}$ Karni, "The Founding of the Finnish Socialist Federation," 65-70.

${ }^{170}$ Mesaba Ore (Hibbing, Minnesota), July 23, 1907.

${ }^{171}$ Pinola, "Labor and Politics," 21-23.
} 
immigrant Finns. Company-hired labor spies attempted to monitor the labor situation across Minnesota, Wisconsin, and Michigan's mining regions, but a spark existed in the working-class population that would not extinguish.

Michigan's Copper Country was especially active in regards to labor organization. From the small, but explosive "Nitroglycerin Strike," to short but violent strike in Rockland, Michigan, in 1906, to a nine month strike initiated in 1913 by the introduction of the one-man drill and dissatisfaction with wages, hours, and working conditions, the Copper Country seemed to be on the verge of turmoil. The 1913-14 Michigan Copper Strike, administered by the WFM, was the most significant expression of worker discontent with changing forms of industrial technology in Michigan's Copper Country. In this nine-month long watershed labor action, a primary grievance registered by a faction of striking mineworkers was the introduction of the one-man drill, a labor saving device introduced by area mining companies. While hours, wages, safety, and working conditions were universal grievances registered by striking mine laborers, it was the one-man drill and the complaints of skilled, mostly-Cornish mineworkers, which brought labor relations to loggerheads. The introduction of the one-man drill would displace up to one-third of the skilled underground workforce. This loss of employment to a new technology brought the previously divided skilled mineworkers and unskilled laborers together to battle the control exercised by Michigan copper companies in work spaces. ${ }^{172}$ This was a significant show of industrial solidarity for the previously splintered Copper Country mineworkers.

\footnotetext{
${ }^{172}$ A published account of the 1913-14 Michigan Copper Strike can be found in Gary Kaunonen and Aaron Goings, Community in Conflict: A Working-class History of the 1913-14 Michigan Copper Strike and
} 
The angst of Lake Superior basin industrial workers had reached a feverish pitch during the 1913-14 Michigan Copper Strike. Though in name a labor action attributed to the WFM, the IWW influenced the strike via Finnish immigrant organizers who were sympathetic to the Wobblies. A bloody and bitter strike, the labor action on Michigan's Keweenaw Peninsula brought new lows to Lake Superior labor relations. The 1913-14 Strike was especially violent and long in duration. During the nine-month-long strike hired mine deputies, strike breakers, and county deputy sheriffs shot and killed two Croatian strikers in Seeberville, Michigan; shot and wounded a fourteen-year-old Hungarian girl in another location on company property; and possibly caused the loss of some seventy-three to seventy-nine immigrant lives, sixty of which were children, at a WFM sponsored multi-ethnic Christmas Eve party for striking workers and their families in Calumet, Michigan's Italian Hall. The mining company powers also planned the beating, which included an accidental shooting, and deportation of then WFM President Charles Moyer in late-December of 1913. Seeing the brutality of the mining companies and their hired thugs go unchecked by local law enforcement, the State of Michigan, and United States bureaucrats, striking workers on Michigan's Copper Range were seemingly coerced, strong-armed, and threatened back to work without recognition of the WFM, which was the main goal of the strike. The 1913-14 Michigan Copper Strike ended in mid-April of $1914 .{ }^{173}$

Italian Hall Tragedy, Lansing, Mich.: Michigan State University Press, 2013. An account of IWW influence in the Finnish immigrant population can be found in Gary Kaunonen, Challenge Accepted: A Finnish Immigrant Response to Industrial America in Michigan's Copper Country, Lansing, Mich.: Michigan State University Press, 2010. ${ }^{173}$ Ibid. 
The WFM, then a part of the conservative American Federation of Labor, had been turned back in the Copper Country, but the radical impulse of organized labor shifted west to Minnesota where IWW sentiment was especially robust in that state's Finnish immigrant population. This radical impulse found expression in the IWW's, ideology and open advocacy for direct action tactics such as industrial sabotage. Minnesota's iron mining companies, for their part, developed a company line to paint the use of sabotage as an un-American act of terror. For "respectable" citizens, sabotage, both withdrawal of efficiency and destruction of the object, loomed like a gray specter over the Lake Superior industrial region, though few outside the industrial milieu understood the actual contexts or contingencies regarding the use of strikes or sabotage. As one fervently pro-mining company newspaper brutally remarked during the 1916 Minnesota Iron Ore Strike:

Law must be enforced. The rights of all must be respected. Men who go on the property of others and coerce workingmen into quitting jobs they want to keep must be prosecuted. If there is no law by which these agitators can be silenced they can surely be controlled in the same manner that is the Negro in the south. For we cannot sacrifice all law and order at the behest of a few radicals, who would in an instant tear down all that our fore-fathers built in past generations....

As near as we can make out this reign of terror is entirely due to that outlawed and unlawful organization, the Industrial Workers of the World well translated in the west, its birthplace, as "I Won't Work." But the fact that the members of this order will not work is not its worst sin. It's an outlaw even among labor unions. Its principle teaching favors "sabotage," which, translated 
means it is the worker's duty to do all possible damage to machinery or property both before and after quitting his job. That is anarchy pure and simple...we are firmly convinced that every man who becomes a member of the I.W.W. obligates himself in favor of 'sabotage' and if he does he is a traitor to the country and should be treated as such. ${ }^{174}$

The above quote summarized the feelings of middle-class employers and wealthy industrialists alike. Sabotage was a treasonous tactic and an expression of un-American attitudes. For better or worse, the IWW's ideological underpinnings now included the advocacy of industrial sabotage, and what exactly this meant was being debated by those in the IWW at that time. For the IWW, sabotage was a fluid ideological construct open to debate, but for most people in the general public, the perception of sabotage was squarely fixed-in negative terms. The ideological adoption of such controversial tactics in the class struggle led many to see the IWW's unique proletarian culture as too radical. Conservative labor unions shunned the Wobblies from serious consideration as representatives of America's working-classes. However, the IWW's unique proletarian culture and rather ingenious cultural apparatuses were beloved by its members. A detailed analysis of Wobbly culture, intangible and tangible, begins in the next section.

${ }^{174}$ The Virginia Daily Enterprise, June 17, 1916. 


\section{Section: Cultural History and Material Culture}

\section{A Solidarity-inspired History Vignette: Filling Capitalist Space, Occupy Movements}

The use of space as a landscape of discontent is quite common in the historical record.

Perhaps the most prominent contemporary use of space as a background to voice opposition to capitalism occurred with the Occupy Movements, which began in 2011. The Occupy Movement became the international arm of the transformative, if not quixotic, United States Occupy Wall Street protests, which attempted to highlight issues of social justice concentrating on economic equality. There was also an anarchist bent to the protests as the hierarchy of modern society was questioned by the thousands of protestors who literally occupied a social space close to Wall Street in New York City. The protesters asserted that there were no leaders in the occupation movement and when a news organization attempted to appoint one by interviewing published author and anthropologist Dr. David Graeber, he refused on the grounds that the protest and the movement did not have a single voice. ${ }^{175}$

Global markets and neo-liberal economic practices are among the main concerns for Occupy Movement members. Being extremely critical of the World Bank and the International Monetary Fund, the decentralized goals of the Occupy Movement, founded in that social space of discontent in New York include altering how large corporations and the global financial system subvert democracy and are the will of the few indifferent to the well-being of the many. While it became a global phenomenon, the

\footnotetext{
175 Occupy Together, "Occupy Movement Homepage," accessed at www.occupytogether.org, on November 15, 2014, and Occupy Wall Street, "NYC Protest for World Revolution," accessed at www.occupywallst.org, November 15, 2014.
} 
first Occupy protest to receive widespread attention was Occupy Wall Street in New York City's Zuccotti Park, which began on September 17, 2011. By October 9, protests were active in over 900 cities across the world. Zucotti Park was the first such occupied space, but the protest grew, moving and occupying spaces around the United States and the world. The only continent unoccupied by the Occupy Movement, was the almost uninhabited and unoccupied landmass of Antarctica. Initially the occupying of public space was met without resistance, but as the movement grew police and political frustration increased. On October 25, 2011, police in Oakland, California, forcibly and violently removed people from the occupied city spaces. By end of 2011, most of the tent colonies across the United States had been cleared. The message, however, remains and the power of democratically organized spaces of discontent as a counter to exploitative institutions captured the public consciousness for almost an entire year in 2011.

Much like the Occupy Movement, striking workers sought to control physical spaces during the 1916 Strike. Unlike the Occupy protesters, however, the striking immigrant workers had a well-developed cultural life to support their revolutionary goals. This well-developed, in-situ cultural apparatus included structures of discontent that provided a type of visual representation of power, solidarity, and struggle. Finnish immigrant social halls took on new meaning as striking workers of all ethnicities gathered in the halls to hear IWW speakers, started parades outside the doors of the halls, and voted in union referendums within the halls' auditoriums. The importance of having intact cultural structures of discontent afforded striking workers the opportunity to call somewhere "home." These structures also stood in stark, but challenging opposition to the social spaces and structures controlled by the bosses. IWW labor halls were the 
material objection to the capitalist dogma of mining company managers. They were essential components in the class struggle, and such physical, permanent structures of discontent would have perhaps afforded the Occupy Movement similar benefits.

\section{Section Introduction}

The aim of analysis in this section is to understand the IWW's cultural history, which includes a look at their material or physical past. In the most general sense this section, which consists of two chapters, will seek to define a broad description of cultural history in Chapter 5 and then cast the Industrial Workers of the World (IWW) as a cultural and historical actor. Included in this analysis of the IWW as a cultural actor is a more detailed examination of one of the IWW's most prolific ethnic population cohorts-Finnish immigrants. Especially significant to the IWW's organizing efforts during the 1916 Strike were the so-termed "Finn Halls" and Chapter 6 centers on a discussion of these halls and their cultural activities as material spaces of discontent.

Cultural history is, arguably, the best methodology to analyze and understand the IWW's complex past. The field can and should be considered an important method of historical scholarship because it is one of the few "histories" that places the lives of ordinary folks at the forefront of analysis. Grounded in an interdisciplinary approach, contemporary cultural history has branches in anthropology, art, cultural studies, literature, and of course history. Due to cultural history's close and specific linkages with cultural studies and history, the work of British Marxist historian E.P. Thompson has been essential to the formation of contemporary scholarly inquiry in the field since the early 1960s. 
Thompson's contributions and influences on United States labor history and contemporary cultural history was that he highlighted the lived experience of "ordinary" people. Cultural history is therefore a field of study that chronicles the history of the everyday through examination of cultural expressions—intangible and tangible. Often criticized as a type of micro-history, cultural history is not a history of the insignificant, mundane, or superfluous; rather, cultural history is an examination of history via Thompson's well known "history from below" or "bottom-up" approach. In this manner, cultural history is akin to Solidarity-inspired History $(\mathrm{SiH})$ in scope. Of significance in cultural history, as in $\mathrm{SiH}$, are historical actors that have been generally omitted from previous historical study. This significance comes across overwhelmingly in authors who have published in cultural history. These authors include Thomas J. Schlereth's examinations of material culture and its conveyance of the everyday via object, in Alan Trachtenberg's critical analysis of power relations in the cultural apparatus in the incorporation of America, and in Warren Susman's study of the importance of a threefingered mouse—Walt Disney's Mickey Mouse—in building hegemony in early $20^{\text {th }}$ century American media. All the subjects of the aforementioned authors' work rely on the assumption that these historical subjects and phenomena have been deemphasized, discarded, misinterpreted, or overlooked by standard academic history that stresses the celebrated, the extraordinary, or the successful. Cultural history, though, provides a voice to the "ordinary."

Peter Burke's What is Cultural History?, is the most comprehensive introduction to the discipline of cultural history. While Burke provides an impressive historiography regarding works in cultural history, he does not, however, provide the reader with a 
concrete idea of what cultural history is. Burke defines culture many times and includes the changing iterations of culture in cultural history well, but decisively refrains from explaining or defining cultural history in concrete terms. This is purposeful, however, as he writes, "the question (of what is cultural history) was asked in public more than a century ago, in 1897 , by a pioneering German historian who was also something of a maverick, Karl Lemprecht. For better or for worse, it still awaits a definite answer.” ${ }^{176}$ Though Burke relates that common ground for cultural historians is found in symbolic interpretation, he shies away from making any further tightly bound definitions or interpretations of exactly what is cultural history.

Instead, What is Cultural History? explains the intellectual movements and subfields in cultural history by providing a descriptive chronology of works in cultural history. From Burke's chronology, four phases are established: 1) the Classical Phase, 1800-1950; 2) Social History of Art, 1930s-1960s; 3) the History of Popular Culture beginning in the 1960s; to 4) the New Cultural History. ${ }^{177}$ Burke gives a very honed background of the discipline's epistemological foundations. This chronology of the discipline is both descriptive and instructive elucidating both practice and theory.

Especially useful is Burke's examination of the New Cultural History, which has become the most prominent focus of analysis in United States cultural history. Burke describes this as the anthropological turn in cultural history with the important notation that theory is a guiding force in the New Cultural History. As Burke writes, "concern with theory is one of the most distinctive features of the New Cultural History." To better

\footnotetext{
${ }^{176}$ Peter Burke, What is Cultural History?, Second Edition, (Malden, Mass.: Polity Books, 2008), 2-3.

${ }^{177}$ Burke, What is Cultural History?, 31.
} 
understand New Cultural History's infusion with theory, Burke outlines the theoretical contributions of three major interdisciplinary historians: Mikhail Bakhtin, Norbert Elias, Michel Foucault, and Pierre Bourdieu. ${ }^{178}$ Given Burke's definition and the outline of cultural history as a field, this chapter will offer a New Cultural History perspective regarding the IWW and its indomitable cultural apparatus. Thus, the chapter will look at the symbolic nature of two IWW media offerings in theoretical terms and posit that the IWW, while described by some in the media and industry, as an unorganized bunch of anarchists and brigands was a very purposeful and structured industrial union.

As a sub-field in Cultural History, the study of physical artifacts perhaps offers the most egalitarian and revolutionary methodology for studying a working-class past as Schlereth asserts that material culture studies create a "more democratic, populist, even proletarian history." "179 In Cultural History and Material Culture: Everyday Life, Landscapes, Museums, Schlereth provides a specific examination of cultural history via definition and analysis of material culture_or more popularly_ "things" or "stuff." Written in 1992, Cultural History and Material Culture provides a short background of cultural history and the relation of material culture studies to the discipline. Using James Axtell's definition of culture as an amalgam for including material culture studies in American cultural history, Schlereth quotes regarding cultural history, "culture is an idealized pattern of meanings, values and norms differentially shared by members of a society, which can be inferred by the non-instinctive behavior of a group from the

\footnotetext{
${ }^{178}$ Burke, What is Cultural History?, 31-33, quote on 49, and 51-58.

${ }^{179}$ Ibid., 157.
} 
symbolic products of their actions including material artifacts, language, and social institutions." 180

Schlereth's previous work in material culture centers on the Victorian era, which he identifies as the dawn of what gave rise to the physical objects that would later become the study of material culture. He pays particular attention to the middle-class in this era because of the burgeoning industries that provided the accumulation of wealth that would push so-termed "white-collar" individuals and institutions into consumers versus producers in an urban and suburban environment. Borrowing from Dr. Daniel Nugent's term "embourgeoisement," Schlereth writes that the Victorian era was, "literally the movement of the middle class to towns, cities, and suburbs and more abstractly the gradual assimilation of segments of the working class into an expanding middle class." 181

As with Burke's appraisal of cultural history, Schlereth provides a critique of material culture studies, but as a part of this critique, Schlereth is prompted to examine just what material culture studies is because it occupies the status of "assistant to" in a number of disciplines and scholarly fields. This discussion prompts an analysis of the place of material culture studies in the academy, the methodological forms of material culture studies (whether to call it a discipline, a department, field, or tool in the scholarly kit), and a call for theory in material culture studies. In the last instance, Schlereth calls for the development of a theoretical framework that encompasses both lower level and more epistemologically rigorous theoretical foundations. ${ }^{182}$ For the purposes of this

\footnotetext{
${ }^{180}$ Thomas J. Schlereth, Cultural History and Material Culture: Everyday Life, Landscapes, Museums, (Ann Arbor, Mich.: UMI Research Press, 1990), 8.

${ }^{181}$ Schlereth, Cultural History and Material Culture, 9-10.

${ }^{182}$ Schlereth, Cultural History and Material Culture, 30-32.
} 
section and the dissertation, material culture will be utilized as a tool to understand the development of working-class culture in striking workers on the Minnesota Iron Ranges in anticipation of and during the 1916 Strike. Especially significant is the role that material culture can play in regards to understanding immigrant, working-class life in industrial America. Because immigrants most often spoke different languages, did not have full access to American social institutions, did not have their documents archived by official government repositories, and were often were not afforded the right to a history, material culture provides a link to the past of immigrant groups. And, as Schlereth writes regarding material culture's rubric, “...it is increasingly being used as the most appropriate generic name describing the research, writing, teaching and publishing done by individuals who interpret past human activity largely, although not exclusively, through extant physical evidence."183

Chapter 6, then, utilizes material culture to expand the study of working-class culture past the written record. The use of material culture as a companion to the New Cultural History supplements the historic record for groups that left little to no archival record. Landscapes, social spaces, structures, and/or other tangible objects can work in combination with a group's historical records to illuminate untold elements of a group's history. The combination of examining a group's material culture with labor, social, and immigration history is perhaps most important to groups whose history has been hidden, suppressed, or stricken from traditional narratives. As Schlereth relates:

\footnotetext{
183 Thomas J. Schlereth, "Social History Scholarship and Material Culture Research," in Material Culture: A Research Guide, (Lawrence, Kansas: University Press of Kansas, 1985), 156.
} 
Both social history and material culture studies challenge the older view of history as past politics, both have sought to demonstrate the great diversity of the American people and their lifestyles, and both have been anxious to expand (some would say explode) the traditional boundaries of American historical scholarship and thereby actually redefine what constitutes American history. ${ }^{184}$

Most significantly material culture is a restoration of "voice" via the tangible object and in such a way works as an essential methodological tool in the framework and practice of SiH. For groups who have had their voice forgotten, marginalized, and suppressed—or in the case of immigrants to the United States ignored due to language barriers—-material culture offers a different avenue to understanding the dismembered past. Material culture studies seeks to restore this history through the tangible object, which is at times much more difficult to erase or forget. Tearing down a building or altering a working-class landscape is a much more intensive project than destroying a written record and it is in the preservation of such tangible objects that restorative power and voice is contained. Material culture, and cultural history in general, can help to preserve this record of the everyday that is often disregarded by traditional historical analysis.

${ }^{184}$ Ibid., 156-157. 


\section{Chapter 5: Fire Starters-the IWW as Cultural Actors}

\section{Chapter Introduction: The IWW and Cultural History}

In understanding the IWW's unique union culture, this chapter will examine two of the Wobblies' most important cultural artifacts. Analysis of the artifacts will demonstrate that the Wobblies were a well-organized industrial union with the ability to produce meaningful artistic and symbolic representations of class struggle. The first artifact under analysis is one of the IWW's most significant yet overlooked works of art, Father Thomas Hagerty's Wheel of Industrial Unionism. The second cultural artifact provided for analysis is a political cartoon published in the International Socialist Review that criticized the use of violence against striking workers during the 1916 labor revolt.

Many of the IWW's detractors argued that the union was a loosely controlled organization driven by chaotic, misguided emotion. Certainly, much of the Wobbly's culture revolved around emotional appeals to and depictions of haggard class struggle, however, upon closer inspection, it is clear from cultural artifacts such as Hagerty's Wheel that the IWW sought to create an organizational and cultural apparatus that was well-organized, purposefully designed, and thoughtfully administered and prepared. Many misconceptions abound regarding the IWW, but Hagerty's Wheel, a little known and less understood artistic representation of the IWW's organizational structure, visually represented a logical resistance to dominant forms of industrial power, such as the "bosses" and a refutation of other United States labor unions.

Before examining the importance of Hagerty's Wheel, this chapter will first outline a broad cultural history of the Wobblies. Describing its historic mission as the overthrow of capitalism by an industrially organized working class, the IWW was 
founded in Chicago, Illinois, in 1905. The groundwork for the beginning of the IWW was, however, rooted in previous socio-economic movements. With branches in theoretical strains of Marxian socialism and Bakunian anarchism, the IWW was a proletarian, yet apolitical union that stressed the emancipation of the working class via anarchist-inspired economic direct action. Ideologically, the IWW shared common ground with various conceptions of revolutionary socialism. The marked difference between the two radical forms of social change revolved around implementation of revolutionary bureaucratic and hierarchical structure and the devaluation of politics as a tool of the proletariat. The IWW was a locally controlled, rank-and-file driven industrial union that became known as the One Big Union, which emphasized working-class solidarity regardless of race, creed, color, job, religion, politics, or gender. As long as a worker worked for wages, and under a boss, membership in the IWW was open to that worker. ${ }^{185}$ This inclusive ethos guided most of the IWW's cultural expressions.

\section{The Wobblies as Cultural Actors}

Alongside the IWW's revolutionary industrial unionism, a dynamic, robust, and vibrant cultural apparatus developed. This significant cultural apparatus included art, athletics, debating societies, libraries, songs, street speaking, union meetings, and the publishing of information, literary, and ideological texts. The IWW created and nurtured their vibrant popular culture by mixing didactic ideological messages with a stylized medium to foster a unique sense of radical and apolitical working-class solidarity.

\footnotetext{
${ }^{185}$ Fred W. Thompson and Patrick Murfin, The I.W.W.: Its First Seventy Years, 1905-1975, (Chicago: Industrial Workers of the World, 1976), 23-33 and Industrial Workers of the World, "IWW Chronology: 1904-1911," on-line at www.iww.org, accessed September 2010.
} 
Especially influential in the shaping of this dynamic culture were the IWW's images of discontent. These images created an immediate effect that visually represented common, everyday themes of class struggle, solidarity, and working-class emancipation. Most often, these images appealed to a sense of emotion and commitment to the IWW's organizational goals, but underlying these emotionally charged images was a strong sense of organizational credibility and thoughtful development, which guided the IWW's appeals to its working-class audience.

In various complaints and criticisms registered against the IWW by outsiders, the union was depicted as chaos inducing nihilists and/or members of a cult of spontaneity that was prone to haphazard walk outs and wild cat strikes. Especially dismissive of the IWW were American communists. In his article on Canadian bushworkers, J. Peter Campbell wrote that American communists derisively compared the IWW to a "Cult of Spontaneity." 186 These characterizations, some advanced by competing communist, socialist, and labor movements, were derogatory defamations to make the union, its organizational techniques, and culture seem to appear jumbled and somewhat reckless. While these portrayals of the IWW were accurate in alluding to an active cultural organization that was artistic, boisterous, and somewhat "smart-assish," the characterizations downplay and de-value the logical organization and structuring of a revolutionary industrial union, which helped to ground the IWW as an effective (but feisty) representative of America's industrial workers. In texts about the IWW's history and organizational goals the union's publishing department worked especially hard to

\footnotetext{
${ }^{186}$ J. Peter Campbell, "The Cult of Spontaneity: Finnish-Canadian Bushworkers and the Industrial Workers of the World in Northern Ontario, 1919-1934," in Labour/Le Travail, 41, Spring 1998, 121.
} 
combat contradictory and dismissive characterizations of the organization, but just how organized or structured was the IWW?

\section{Father Hagerty's Wheel}

While most IWW histories and historians transfix analysis of the IWW's highly provocative and emotionally charged cartoons of class struggle, perhaps the most revolutionary work of IWW “art” was Father Thomas J. Hagerty's "Wheel of Industrial Unionism." Father Hagerty was at one time an actual Catholic priest, but an unusual one at that. He finished seminary in 1895 , served as a priest in Chicago for a short time, and then relocated to the American southwest. At first advocating working-class issues in an ecclesiastical custom, but later in a revolutionary manner, Hagerty fell into disfavor with the church. As a member of the Socialist Party of America, Hagerty edited the American Labor Union's newspaper, the Voice of Labor. As Hagerty became more involved in socialist causes, the Socialist Party of America became too restrictive for his growing revolutionary perspective, and by 1905 , Hagerty had drifted into the IWW's fold. ${ }^{187}$

Much of what the IWW published to promote the organization's goals of a decentralized, rank-and-file controlled revolutionary union were carefully constructed images and texts of working class discontent designed to pull on the heartstrings of future and present union members. While decentralization was the goal, the apparent need for some type of structure was evident as early as 1905. Into this organizational quandary strode Father Hagerty and his experiences with the highly structured Catholic Church.

\footnotetext{
${ }^{187}$ Melvyn Dubofsky, We Shall be All: A History of the IWW, Industrial Workers of the World, (New York: New York Times Book Company, 1969), 91-93 and Thompson and Murfin, The I.W.W.: Its First Seventy Years, 1905-1975, 6 and 12.
} 
Hagerty proposed and artistically rendered a very logical organizational structure for the revolutionary IWW. He visually interpreted this structure as a wheel with equally apportioned industrial units with the intention of uniting workers of all crafts, trades, races, political affiliations, and genders into one big industrial union. What Hagerty proposed with his wheel was a highly organized industrial union comprised of numerous industrial jobs and general membership branches as spokes that led inward toward departmental administrations, which in turn led to a Central Administration that radiated around a President at the center of the organization. So, while the IWW's cultural apparatus was very effective and radical, the work of organizing rank-and-file members in an industrial union, according to Hagerty's Wheel, could be a very logical and wellthought out process.

As for the actual cultural artifact, Father Hagerty's Wheel was a one-dimensional disc of logically ordered industrial classifications. It was in essence a taxonomy of industrial work. Rooted in modernist ideas of classification, Hagerty's artistic rendering of the IWW's organization was like an industrial unionist's Periodic Table of Elements. Unlike the Periodic Table, which separated elements by composition, the purpose of Hagerty's classifications was to bring workers together in one synergistic industrial union that was stronger because of its separate parts. Each department of industrial jobs from the Department of Food Stuffs, which included workers in dairies and breweries, to the Department of Public Service, which included postal workers and hotel chambermaids, had a place in the One Big Union. This highly organized wheel was antithetical to outsiders' conceptions of the IWW's Cult of Spontaneity and haphazard ways. While the 
IWW's radical literature nurtured revolutionary ideals, Hagerty's Wheel seemed to represent steadfast organizational structure.

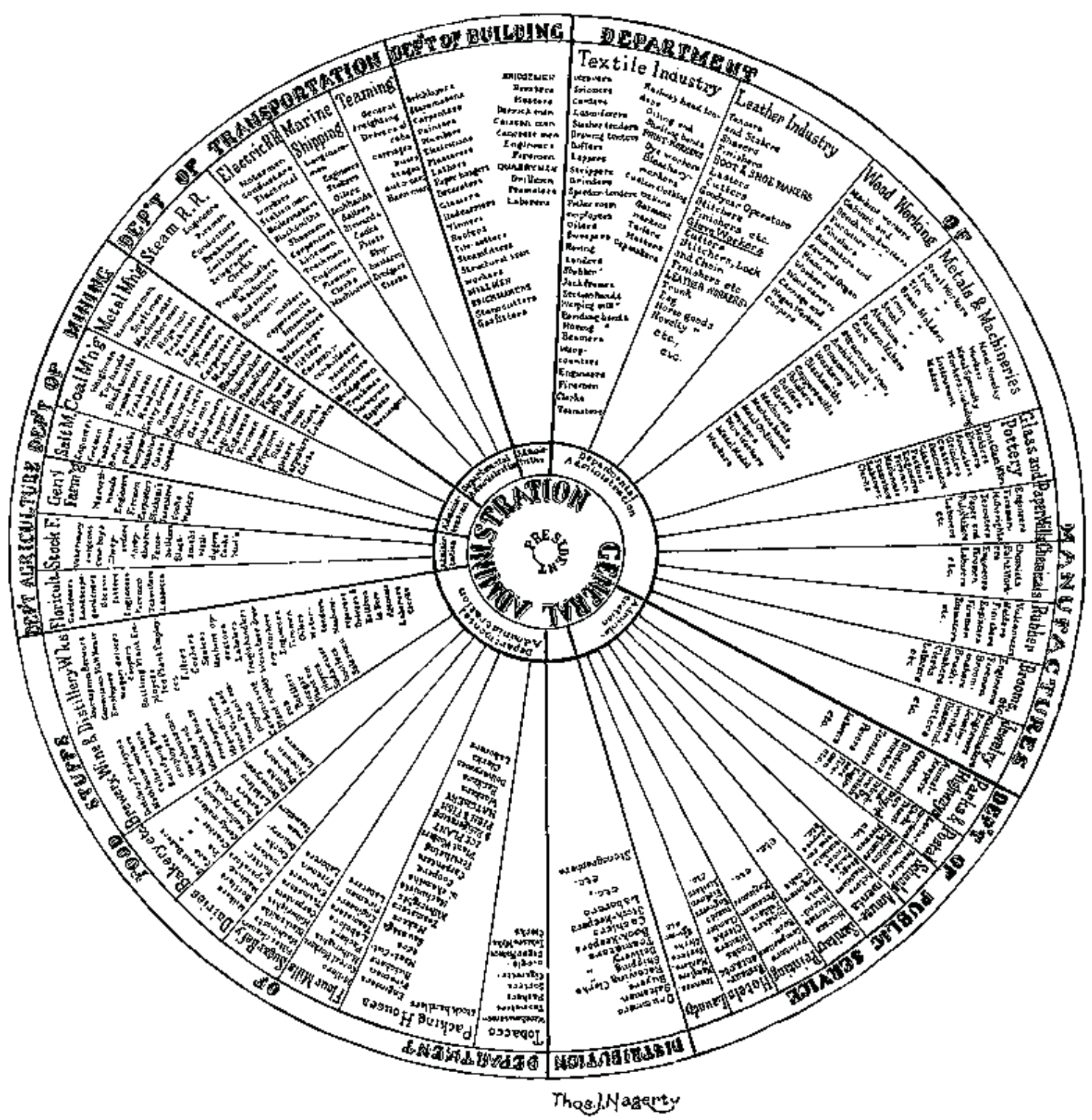

Figure 5.1-Image of Father Hagerty's original "Wheel," ca. 1905-from www.iww.org

Hagerty's Wheel provided a logical visual representation of industrial unionism.

While Father Hagerty's Wheel was a rational visual representation of revolutionary industrial unionism, it was also a cultural art form that was different in form and function 
from the IWW's other revolutionary imagery, which was created to elicit an emotional response. Hagerty's Wheel was an artistic rendering of resistance to laissez-faire forms of capitalism, the apprenticeship system of craft and trade unions, and socialist and communist forms of hierarchical bureaucracy. As art and organizational representation, Father Hagerty's Wheel symbolized the values that were present in the IWW's revolutionary union culture by proposing a radical, new way to structure union organization. In the design and development of his wheel Hagerty stressed a common sense, logical order for the IWW's revolutionary organizational goals. As labor historian Melvyn Dubofsky wrote about the wheel, "(it) involved a 'general administration' at the hub, five departments at the circumference, and thirteen industrial divisions in between." ${ }^{188}$ Throughout the years and several re-renderings, Hagerty's Wheel became more stylized and artistic, but its original purpose as a logically derived, artistic symbol of resistance to customary union organization remained well into the 1950s.

However, a closer examination of Hagerty's Wheel reveals that while the IWW outwardly sought to eschew the devices of hierarchical bureaucracy, the union's organizational structure, at least in Hagerty's 1905 interpretation, retained a concept of centralization. In Hagerty's original wheel there was indeed a "Central Administration" and "President," which were especially contrary to the IWW's declarations as a decentralized rank-and-file powered organization. While Hagerty seemed to be attempting to give order to an organization that was in flux, especially early in its history,

${ }^{188}$ Melvyn Dubofsky, We Shall be All, 86. 
his wheel ran contrary to other artistic renderings of the IWW's decentralized public image and created controversy among the founding members of the organization.

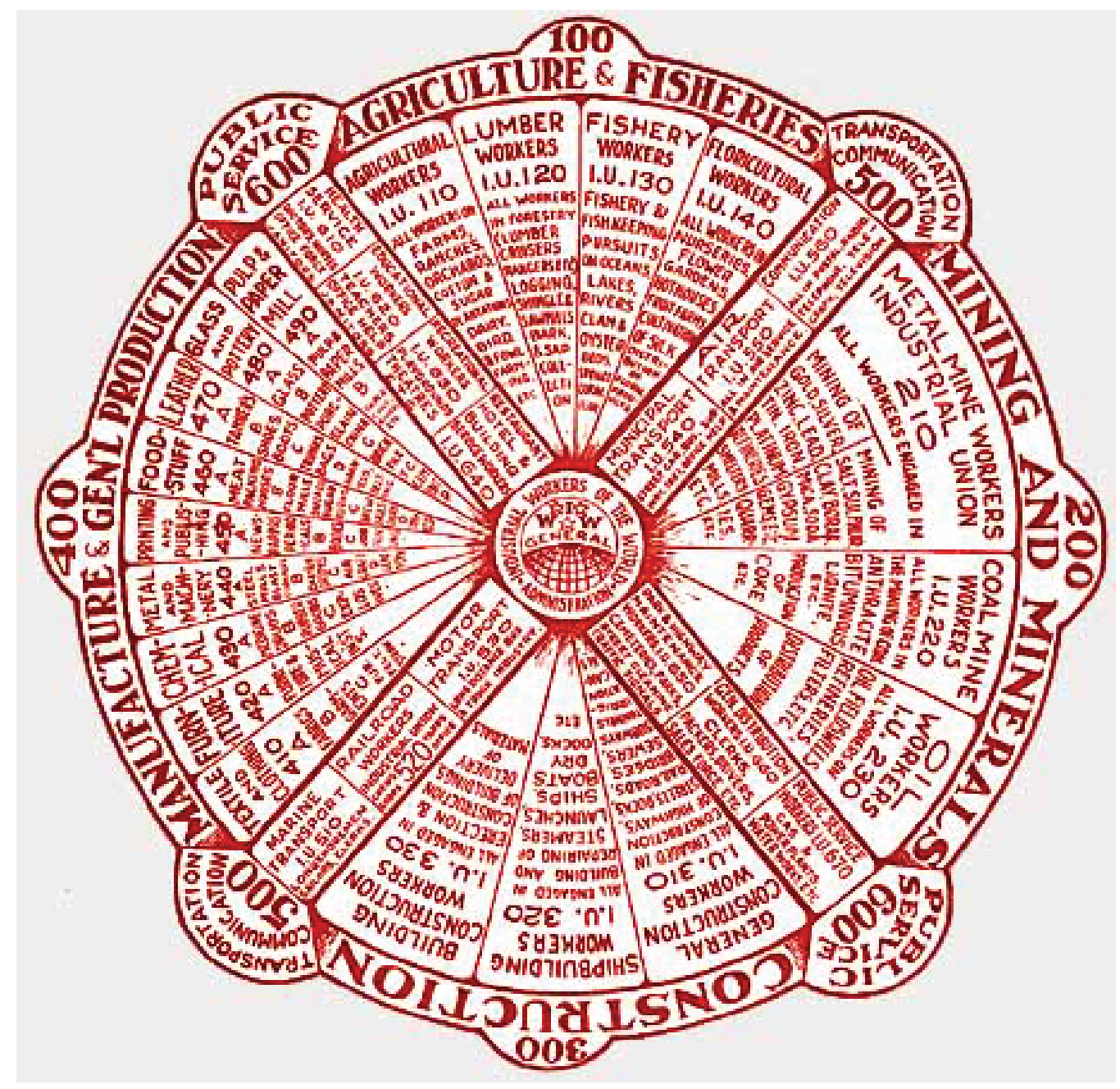

Figure 5.2-Stylized version of Father Hagerty's Wheel that does not contain a "President" at the center of the wheel, ca. 1920-from www.iww.org

A stark contrast between Hagerty's 1905 wheel and the above stylized 1920s version of the wheel was the absence of a "President" and "Central Administration." Hagerty's original version of the wheel met with stiff resistance from anarchist-minded members at the IWW's founding convention. The general concept of Hagerty's vision for industrial unionism was accepted, but the particulars of the administration were debated. 
The outcome of the debate was that latter versions of the wheel contained a "General Administration" at the center, and while the substitution of a General Administration for a Central Administration was perhaps more a question of semantics it highlighted the IWW's keen sense of creating a closely monitored identity, image, and organizational awareness. Thus, while the IWW had a type of centralized structure, the union refrained from ever electing a President or having a principal figurehead, instead choosing to situate administration in the hands of an elected group of leaders with the union's General Secretary becoming the first among equals.

When looking past the wheel and towards the lived experience of its author, perhaps one could conclude that while Father Hagerty was interested in revolutionary industrial unionism, he was not fully willing to depart from the centralized bureaucracy he had embraced as a priest in the decidedly hierarchical Catholic Church. Perhaps the standard axiom, "old habits die hard," applied to the situation and when crafting an organizational structure for what would become a very radical industrial union, Father Hagerty came to rely on a somewhat traditional sense of order, standard political figureheads, and customary chain of command.

Probably the single most important critique of Hagerty's Wheel for future union growth was that it was not very flexible or responsive to the needs of an evolving union organization and changing industrial society. The wheel too rigidly defined the structural groupings of industrial work and has undergone revisions throughout the years to account for changing industrial production and new job categories. The IWW has, however, retained the basic organizational and numbering system proposed by Hagerty over one hundred years ago. The modern IWW has ventured into union organization in industries 
that Hagerty probably never could have imagined, including information technology, fast food, and sex workers. So, while Hagerty's initial artistic representation of revolutionary industrial union structure has not stood the test of time, the IWW's commitment to struggle and resistance endures. While other industrial unions have folded or been absorbed into larger, corporatized federations, the IWW has managed to stay in existence as a decentralized revolutionary union in an ever-changing industrial society.

\section{'Under the Stars and Stripes on the Mesaba Range":}

\section{Radical Cartooning and the 1916 Strike}

The second part of this chapter contains a contextual look at the power of visual representation to communicate complex cultural meanings, such as class struggle, solidarity, and worker discontent, through cartoons. Broadly, the balance of the chapter will examine the intersection of a graphic medium, an industrial union, and World War I, all set in the context of one of the most violent and significant labor actions of the early $20^{\text {th }}$ century-the 1916 Minnesota Iron Ore Strike. More specifically, this part of the dissertation will examine how a cartoon published in the International Socialist Review came to agitate for anti-militaristic free speech in the fight to unionize the Minnesota iron ore mines in 1916.

IWW cartoons, and radical cartoons in general, excelled in the forging of classconscious literacy and solidarity due to the deft transmission of unique proletarian cultural imagery using common and iconic themes of class struggle. These depictions educated workers about their own plight and the IWW's fight to help workers organize to create a more just industrial world. This was the power of the IWW's proletarian culture, 
and more specifically, this was the power of the cartoon as a medium to transmit ideas of collective action, solidarity, and struggle.

Although often seen as a children's media format, cartoons, and especially radical cartoons, have been a staple of the non-literal voice of discontent with capitalism for decades. As a printed form of communication, cartoons had/have an incredible strength to convey a message and communicate an ideal and this power in graphically depicting meaning was used with great success by groups hoping to subvert the dominance of capitalism in the post-Gilded Age of American history. In his article about cartooning capitalism, Michael Cohen highlights the artistic achievements and subversive attributes of political cartoonists Arthur Young, Ryan Walker, and Ernest Riebe, an IWW cartoonist. Of the function of radical cartoons, Cohen writes:

Radical cartoons helped to forge a class-conscious politics of laughter that at its best riotously mocked the values of the capitalist system. These cartoons set out to puncture the self-assumed legitimacy of a newly consolidated corporate ruling class, and dramatized radical solutions to the injustices suffered by those both physically and mentally enslaved by capitalism's mass produced delusions of right, necessity and "The American Dream." 189

As Cohen indicates, radical cartoons had the ability to depict biting satire and humorous metaphor, but they also had the capacity to place in the abstract deadly serious ideas and events. The capability of the cartoon to show complex ideas in a graphic

\footnotetext{
${ }^{189}$ Michael Cohen, "Cartooning Capitalism: Radical Cartooning and the Making of American Popular Radicalism in the Early Twentieth Century," in International Review of Social History, (Cambridge: Cambridge University Press, 2007), 36.
} 
representation gives the medium a vital credibility when transmitting ideas to an audience that would be less receptive to standardized texts and philosophical tracts. This fact perhaps makes cartoons a valued medium for the transmission of revolutionary cultural constructs. As Scott McCloud, cartoonist and theorist, proffers "when certain cartoonists choose to center on the creation of images that feature ideas or principles these cartoons tend to come from artists who are pioneers in the field or espouse revolutionary ideals." 190

Additionally, as George Dardess, English professor and graphic novelist suggests regarding the place of the comics in refined society and their influence upon the general audiences, "like other forms arising from the masses...the comic strip has been met with indifference and even at times fear and hostility from higher, more educated groups... [educated groups find] the comic strip essentially a childish anarchic, potentially subversive medium." ${ }^{191}$ In the temporal period of analysis for this chapter, the cartoon as an art form had immediate credibility expressly due to the alterity of the format. Relating this idea to the context of this dissertation, radical cartoons had influence with workingclass populations because of their subversive content, but also due to the perception that they were not high cultural forms of artistic expression.

As a medium seemingly sanctioned by the masses, cartoons have been effective communicators of abstract ideas in a simple, yet meaningful graphic form. Cartoons are able to capture specific events in the abstract, which allows for the display, identification,

\footnotetext{
${ }^{190}$ Scott McCloud, Understanding Comics: The Invisible Art, (New York: Harper Paperbacks, 1994), 177182.

${ }^{191}$ George Dardess, "Review, Bringing Comic Books to Class," in College English, Vol. 57, No. 2, National Council of Teachers of English, Feb. 1995, 216.
} 
and interpretation of ideology in a graphically and aesthetically pleasing manner.

Cartoons visually portray what photographs often need to caption or fail to communicate even with a well-written caption. In her book on radical transnational social movements, violence against those movements, and visual culture, Radical Sensations, Dr. Shelley Streeby argues that, "political cartoons were an important [communicative] form...because they offered a way to comment on atrocities without reproducing the sensational spectacle of violence.” As Streeby concludes political cartoons offered artists the opportunity to control meaning in ways that photographers could not. ${ }^{192}$ While photographers seem to capture events in time (unless actors are posed), cartoons and their artists are able to visually construct or pose an event, individual, or occurrence to elicit a specific emotion or articulate an argument. This makes the cartoon as art form a perfect visual medium to portray discontent, visually design solidarity evoking scenarios, and graphically feature scenes of class struggle.

Given these interpretations of cartoons as an artifact of popular, working-class culture, this chapter shifts to the analysis of a cartoon published as warning and call to action during the 1916 Strike. To agitate and bring awareness to the plight of IWW members and satirize the loss of free speech on the Mesabi Iron Range during the Strike, the International Socialist Review, a publication sympathetic to the Wobblies, published the above cartoon as a companion piece to an article regarding the arrest of one of the IWW's most talented organizers, Italian immigrant Carlo Tresca. Tresca's abilities as an organizer made him a lightning rod for publicity and scrutiny from local law enforcement

\footnotetext{
${ }^{192}$ Shelley Streeby, Radical Sensations: World Movements, Violence, and Visual Culture, (Durham, North Carolina: Duke University Press, 2013), 14.
} 
officers and the "kept" or company-affiliated press. In the summer of 1916 he was arrested for carrying a banner that read, "Murdered by Oliver Gunmen," which was an attempt to bring attention to the killing of IWW member John Alar, who was shot by mining company gunmen in a fracas during the strike. ${ }^{193}$

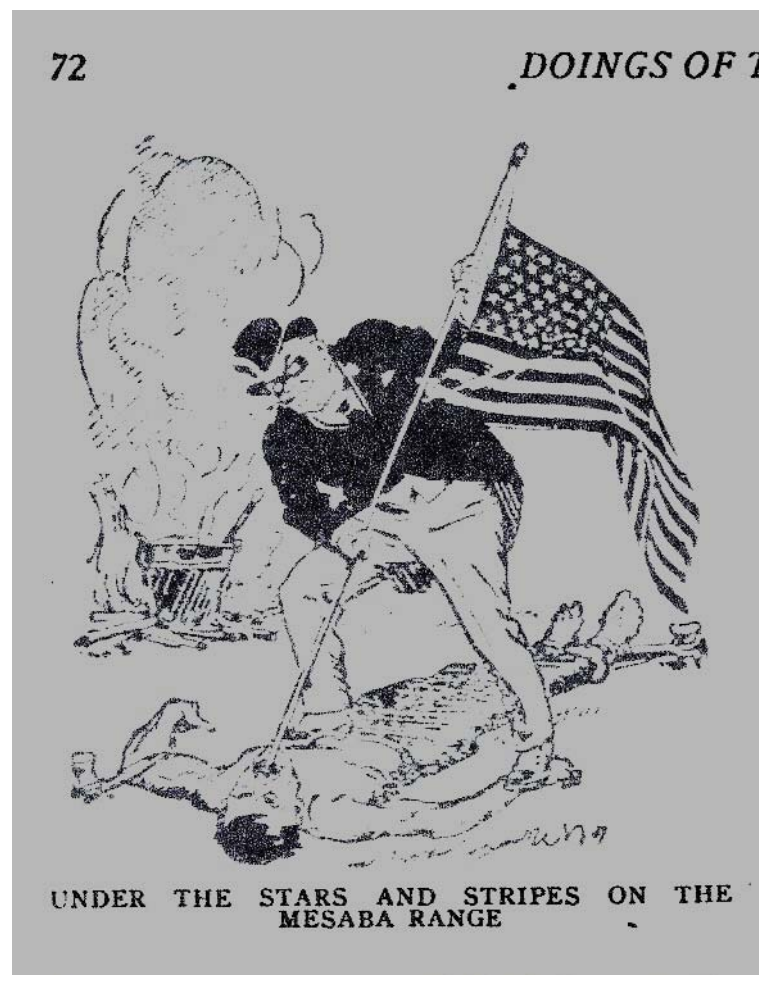

Figure 5.3-"Under the Stars and Stripes on the Mesabi political cartoon from the August 1916 issue of The International Socialist Review

Though he denied carrying the banner, the local police force arrested and jailed Tresca for criminal libel. This arrest prompted the International Socialist Review to print the cartoon with a rather rambling, somewhat incoherent article about Tresca's arrest, militarism in the United States, and the struggle for free speech on the Iron Ranges. As the International Socialist Review opined:

${ }^{193}$ International Socialist Review, "Doings of the Month," 71. 
If such events as those which have occurred in the Mesaba range cities were impossible, if working men asserting the decent and human rights of men were not subjected to a false arrest on false charges based on false laws, it would be easier for the stupid and greedy munitions interests of this country to enlist workmen for war. So long as the working class feels that the flag stands for property instead of men, women and children, so long will the flag be taken as a joke by workmen such as those on the Mesaba range, for whom the flag represents nothing but suppression, handcuffs, bars, and bread and water from tin dishes. ${ }^{194}$

Quite frankly, as an effective argument against militarism and for free speech, the rather haphazardly composed article fails miserably, but where the written article tumbles, the skillfully drawn companion cartoon somersaults into a very effective visual argument about the force feeding of nationalism to a an industrial proletariat who have been denied their First Amendment rights.

What is occurring in this image is a type of myth-making around a shocking, graphically portrayed idea of class struggle against capitalistic, militaristic, and nationalistic hegemony. This construction of a visual proletarian mythology is purposefully crafted by using the American flag's representation of personal freedoms to evoke a strong emotional response to repression of an IWW member's right to free speech during the course of the strike. As Marita Sturken and Lisa Cartwright note about Roland Barthes' definition of the term myth in visual representation, "[He] used the term

${ }^{194}$ International Socialist Review, "Doings of the Month," 72. 
myth...to refer to the cultural values and beliefs that are expressed through connotation. For Barthes, myth is the hidden set of rules and conventions through which meanings... are made to seem universal and given for a whole society [or in this case community]."195

This cartoon's author was able to freeze a moment in time, and assign ideology, meaning, and myth to Tresca's plight. In essence the artist "posed" an event on the Mesabi Iron Range and although a capitalist never stuck an actual American flag down an IWW organizer's throat, the ability of the cartoon to place events in the abstract allows the artist to graphically represent the strikers' loss of free speech during the labor dispute, which absolutely did happen. The loss of this basic human right did regretfully occur and people were arrested and jailed for expressing their beliefs. And, while there were no photographs of people being jailed for this, a skillfully drawn and designed cartoon conveys meaning in a more appealing and purposeful manner. Furthermore, instead of just having the article's text relate the situation of repression of human rights on the Minnesota Ranges, the cartoon visually portrays this very complex message with the use of iconic symbols such as the United States' flag (a representation of nationalism), the iconic capitalist robber-baron figure, and a tied down, raggedly clothed man being forcefed patriotism. The representation is very effective in creating a visceral, emotional response to a rather convoluted and abstract topic. As could be concluded from Barthes' ideas regarding signifier and signified, this image's intended capacity is to visually portray physical repression of a basic human right, which acts as the signifier to create a

\footnotetext{
${ }^{195}$ Marita Sturken and Lisa Cartwright, Practices of Looking: An Introduction to Visual Culture, $2^{\text {nd }}$ ed., (New York: Oxford University Press, 2009), 20.
} 
shared sense of mythologized meaning: class struggle against the loss of basic rights and the hegemonic forcing of nationalism by capitalist social actors who have a brutal, choking strangle-hold on the resources of an area, including the law. ${ }^{196}$

Thus, the signified sign in the image seeks to bring forth an anticipated viewer response: awareness of Tresca's plight, class struggle against brutal oppressors, and a call to action against such barbaric measures as depicted in the cartoon. This is a key ingredient toward the evocation of collective myth-making and the forging of a collective, shared meaning. The formation of this type of class consciousness strives to understand images, such as the one depicted in the article in the International Socialist Review, in anything other than a dominant or primary connotation. Viewers of such images seldom need to look past the dominant features of an image. The negotiated image varies little from the producer's intended meaning. Images that elicit an instant, denotative recognition are intended to conjure up specific emotions in their viewers. It is this emotion, then, that supports the image's ability to perpetuate myth, thereby creating a type of shared, pure sentiment against the injustices of class and a top-down hegemonic social order organized around the mining industry in Minnesota. ${ }^{197}$

This solicitation of pure emotion was especially significant to the disconnected immigrant populations who lived and worked on the Minnesota Iron Ranges. Though these immigrant groups spoke different languages and came from very diverse cultural backgrounds, the image and the message of a fellow worker being force-fed the American flag had a solidarity inducing effect that transcended such language or cultural

\footnotetext{
196 Sturken and Cartwright, Practices of Looking, 28-30.

${ }^{197}$ Sturken and Cartwright, Practices of Looking, 26-27 and 50.
} 
boundaries. It is in this unwritten context that the image had power and derives meaning for those engaged in working-class struggle against massive hegemonic, well-heeled mining companies. In essence, the power of this particular cartoon, and radical cartoons in general, is not the actual lines, shading, or aesthetic values on the page, but rather what type of shared meaning the cartoon evokes from its proletarian audience. The true power of the medium is not in the making, but rather in the construction of a shared meaning that supports such complex ideas as class struggle, worker discontent, and working class solidarity.

Radical cartoons, their artists, and the publications that printed such subversive images were important contributors to the success of organized labor's efforts to critique, parody, and satirize American capitalism. Though perhaps considered a lower art form by refined society of that time this seeming detractor was in fact a boon to the cartoon's credibility with its intended audience. Perhaps radical cartoons could best be described as art for the masses, and in such a framework their descriptive and emotive power immediately becomes entrenched in the very idea of class struggle.

The IWW's use and sanctioning of radical cartoons as an effective medium for communication, especially during the internecine period before World War I, was one of the most effective weapons employed in class struggle and the creation of solidarity among fellow workers. These cartoons reinforced the IWW's cultural cachet with working-class immigrant audiences. The power of cartoons as a visual representation of complex ideology effectively created a simple, yet at the same time intricate, method of forging shared symbolic meaning across ethnic, cultural, and language barriers. This 
function was crucial to the IWW's ability to organize workers for large scale labor actions such as strikes.

It is perhaps doubtful that the International Socialist Review or the IWW understood the effectiveness of cartoons in such a manner, but what they probably did understand was the incredible power cartoons had to viscerally portray complex ideas of class struggle and solidarity to disparate and often times illiterate audiences. In essence, the IWW was attempting to create and identify the Iron Ranges' working-class culture on the fly and in some ways by the seat of their pants, to use a colloquialism. Working-class culture existed on the Iron Range before the IWW jumped into the 1916 Strike, though this culture was fragmented and somewhat disrupted by ethnic rivalry, language, and even religion. The IWW's goal was to create solidarity between these working-class groups through the expression of a unified working-class culture and the IWW's cultural symbols—be it Hagerty's Wheel or a political cartoon—were geared toward this goal. The IWW also enlisted physical expressions of working-class culture and social spaces of class struggle—physical spaces of discontent—such as labor halls and strike landscapes to aid in the unification of the Ranges' working-class population. These tangible, physical spaces of discontent are the subject of the next chapter. 


\section{Chapter 6: Social Spaces and Melodic Voices of Fiery Discontent}

\section{Chapter Introduction: The Material Culture of Discontent}

For many of the Iron Ranges’ immigrants, America was an imposing industrial landscape. Most immigrants in the early $20^{\text {th }}$ century such as Finns, Italians, and Slavic peoples came from agricultural backgrounds and were wholly unfamiliar with industrial life, exploitation, and union organization. The reality of being in an industrial, corporatecontrolled environment forced immigrants to develop a response to their new, often tightly controlled surroundings. In developing these responses, the meshing of Old World traditions and New World expectations collided to form unique, working-class vernacular landscapes and cultural practices. At times such landscapes and practices were temporary, malleable, and shifting, such as a street parade, a picket line, or the location of a street corner speech, but at times these landscapes were more permanent as in the construction of buildings and structures that housed immigrant voices of opposition to American capital—-these were landscapes and spaces of discontent.

The power of vernacular landscapes and cultural practices to reinforce new working-class identities and support a collective working-class culture on the Iron Ranges' in the early $20^{\text {th }}$ century is the subject of this chapter. Immigrant spaces of discontent and the material culture that supported their existence contained the most effective challenges to American capital at the time and provided a foundational counterargument to capitalists' requirement of assimilation to the tenants of the Protestant work ethic. Social(ist) and labor halls and the activities that occurred in them left a significant cultural footprint on the Iron Ranges. Interpreting this footprint as a cultural landscape of discontent focuses the analysis of labor-management relations in a 
concrete manner. The vernacular cultural landscapes created by immigrant groups expressed a disregard for the authoritarian power of multi-million dollar mining companies. Finnish immigrants were especially prolific in this endeavor. With the building of large, architecturally ornate halls Finnish immigrants were in essence creating an oppositional dialogue with American capital, "Oh, you have got huge, fancy buildings dedicated to controlling and exploiting workers? Yes, well, we have equally huge and fancy buildings dedicated to defying your power." During the 1916 Strike, these buildings constituted the physical embodiment of immigrant working-class discontent as they housed union meetings, set the stage for street parades, and hosted raucous singalongs that were spurred on by IWW songs collected in cherished Wobbly songbooks. The material culture of the Ranges' working-class population brought once divided immigrant groups together to challenge the power of American capital.

\section{The Finn Hall as a Fiery Space of Discontent}

This chapter will examine the material culture of working-class groups on Minnesota's Iron Ranges, paying special attention to the most effective physical element of IWW organization on the Ranges—space—namely the labor hall and its valued hall culture. In such an examination of material culture and the development of working-class space, one group and their structures become a central focus of the 1916 Strike. Though the Minnesota Iron Ranges were inhabited by dozens upon dozens of different cultures and ethnicities, from Croatians, to Italians, to Slovenians, to Russians, one group of immigrants stood out as proficient cultural and political organizers. Finnish immigrants occupied a place as ubiquitous cultural beings and as such erected supplemental cultural structures to house social activities. As the roughly 300,000 Finnish immigrants entered 
the United States, they looked for familiar or recognizable social activities to supplement their work lives. While they most often sought a new life in the New World, they also sought to maintain cultural identity, possibly to ease the transition to life in America. Finnish immigrants established cultural organizations that nurtured and supported their unfamiliar existence in America, thus organizational societies became very popular and Finnish immigrants developed vibrant associational lives.

A significant tangible aspect of Finnish immigrant cultural organizations was the highly valued social hall. Akin to contemporary social media, Finn Halls were an important cultural space in the Finnish immigrant's everyday life. Such halls were often the home or an incubator for a unique, concerted response to a new life in industrial America. From these halls, Finnish immigrants responded to their material conditions in a proactive manner. Finnish American historian Michael G. Karni posited that Finns were hoping to maintain and disseminate their values in America: "Most Finns were determined not to be passive recipients of American culture. Whether associated with the church, the temperance movement, the cooperative movement or the radical labor movement, they believed they could shape the American environment and shape it into what it was not." ${ }^{198}$ Finn Halls across the Lake Superior region were shaping up to be oppositional spaces of fiery opposition to American capitalists and capitalism.

Finn Halls became the locus of radical activity in the Lake Superior region. As A. William Hoglund wrote, “Socialist followers paid dues, read party newspapers, attended classes, and if possible, joined trade unions. Then too, they were reminded to attend their

\footnotetext{
${ }^{198}$ Michael Karni, For the Common Good, Superior, Wisc.: Työmies Society, 12-13.
} 
socialist hall, even if there was no dancing, there were speakers, actors, singers and poets to instill moral discipline." ${ }^{199}$ In addition Karni noted that, "at the (socialist) hall, he (the Finnish immigrant) could mix with all his countrymen, be entertained regularly, be culturally enlightened, find self-expression through drama, debate, music and athletics and simultaneously feel himself involved in a movement which promised to bring the good life to all through social and political revolution."200

Fred Torma, an early socialist and union organizer, remembered the importance of halls in the creation of working class culture: "I always went to the halls whenever I had the opportunity." Oftentimes temperance halls, devoted to abstinence from alcohol, were permitted on company property. However, once labor organizers such as Torma entered the scene, the temperance halls were slated for takeover by working-class groups as Torma recounted: "the first place was at Stevenson Mine...I began organizing work to get [socialist] members into that temperance league [so we could take over the hall]. I was always somewhat successful at that...we tried to take over that hall then so that we could also take up working people matters, but the mining company intervened." Labor halls were, of course, not welcome on company property and "[the company] sent representatives to say that they had provided the money and materials for the hall and it would not be used for any labor movement purposes."201

Socialist and labor organizers then turned to other locations and at times existing buildings, which were in urban areas off company property. After being turned away

\footnotetext{
199 A. William Hoglund, Finnish Immigrants in America, 1880-1920, Madison, Wisc.: University of Wisconsin Press, 1960, 98.

${ }^{200}$ Karni, For the Common Good, 82.

201 Torma, “Oral History Interview," 26-27.
} 
from the hall located near the Stephenson Mine, Torma and other socialist-unionist Finnish immigrants targeted a building in Nashwauk, Minnesota, a municipality in Itasca County. Torma remembered, "it was November maybe October when we bought that hall [in Nashwauk]. Then the question arose-how would we pay for it?" Cultural activities, such as plays, concerts, and dances were as much an economic necessity to support the hall as they were ideological disseminators of working-class culture. Torma led the way at creating an ideological, paying venue: "since I had learned the carpenter's trade from my father I said I'd lead. I made drawings as best as I was able. The older ones thought we should merely put planks on top of beer kegs and keep performances on top of that. I said no we won't do that." Perhaps pride in their working-class culture led many to expect more from their social spaces as Torma related that they "built a proper and sturdy stage—for plays, performances, speeches, etc. But we could only—since it was a small hall—only 12 feet—but even then with small plays we could perform on it... so we built the stage. I got others to help-I worked at the mine and didn't have time to be there other than on evenings and Sundays. The others helped and we made a nice, little stage where we could act out plays." 202

In addition to plays the Nashwauk hall served as a location for other functions as Torma remembered: "We practiced all sorts of agitation from there. On Monday evenings we held a committee meeting to plan out the week's activity," and from there the rest of the week's activities took shape, “...then on Tuesday evenings were the rehearsals for the plays. On Wednesday evenings were dances. On Thursday evenings again were play

202 Torma, ”Oral History Interview," 35-40. 
rehearsals. On Friday evenings we met for debating. On Saturday evenings were dances again. And on Sunday evenings the plays were performed." It was a busy cultural life, all housed in a building dedicated to the promotion of working-class culture and as Torma lovingly reminisced, "every day there was some activity. The week was all taken up." The aforementioned was simply the bill for adults. There were activities for the youth as well: "for example, on Monday evenings, when the young wanted to gather, as many did, we had different group games for them to play. And if someone happened to be present who played an accordion we held dances. This was to get the young involved. That was a great deal of fun. If there was no musician we played games and sang." 203

Oftentimes, the plays, dancing, and other cultural activities were often not overtly didactic and were designed to simply get people together and relieve the drudgery of industrial life. However, there were plays, debates, and other activities designed to instruct in the ways of agitation and organization. Especially important was the establishment of a library and as Torma recalled of the Nashwauk Hall, "at that time everyone had a desire to learn. For example because wages were, at the most, $\$ 2.00$ for a 12 hour day no one could afford to purchase books." The Nashwauk local of the FSF planned for a library to elevate the members' intellectual lives. "So we established a library. Then at the debate clubs that we had one had to be knowledgeable in order to defend one's point of view. That also was a reason for our library. Our library grew so big that we had up to 500 volumes. It was all socialist literature," according to Torma. ${ }^{204}$

\footnotetext{
203 Torma, "Oral History Interview," 1-4. ${ }^{204}$ Ibid.
} 
Most importantly, socialist halls became a cultural core to their members. Aarre Lahti, who grew up in Ironwood, Michigan, recalled the Palace Finn Hall as the place of his "most vivid memories of the town [with] the most formative impact on me." Lahti was especially taken with and proud of the work that went into the development of classconscious culture, remarking that "these immigrant laborers, without any assistance from the town's financial institutions, used their own energy and determination to erect this huge hall in a series of work bees. The hall, after completion, boasted the best dance floor in the county and a stage with all the necessary scenery, costumes, and mechanical equipment for a first class little theater."205

Lahti also commented on one other important aspect of hall life, athletics. For immigrant socialists the revolution was a mind and body experience and keeping fit also seemed to be an important part of hall life. Lahti remembered of the Palace Hall: "it was the only facility in town with gymnastic and track paraphernalia. The athletic sessions were held on Tuesday and Thursday evenings and again on Sunday morning when the hall's auditorium was set up with parallel bars, a high bar, 'horses,' mats and other gymnastic equipment. The weekday sessions began about five o'clock to accommodate those who were on the night shift." He continued in great detail about the athletic activities, "hop-skip-and-jump, the long jump, high jump, and the shot put were practiced," but "the discus-heaving was too erratic to be practiced there and the length of the property did not permit any javelin throwing, either."206

\footnotetext{
${ }^{205}$ Reino Hannula, An Album of Finnish Halls: Yesterday and Today, (Finn Heritage, 1991), 23. ${ }^{206}$ Ibid.
} 


\section{Range Labor Halls as Wobbly Spaces of Discontent}

The Finnish immigrant socialist halls of Virginia, Hibbing, and smaller municipalities such as the Nashwauk Finn Hall, provided a staging area for agitation and organization across the Iron Ranges. In the early days, Finns were the main beneficiaries of this vibrant cultural life, but after 1907, Finns began to agitate and organize outside the doors of their own social spaces of opposition. The Finnish Socialist Federation (FSF) and its members learned an important lesson from the 1907 Mesabi Strike and carried it over into the years before the 1916 strike. Working with the Western Federation of Miners during the 1907 Mesabi Strike and the 1913-14 Michigan Copper Strike had brought the socialist-unionist Finns to see their halls not as closed, walled off ethnic social spaces, but as vital components of a unified struggle in times of industrial unrest. From the 1907 strike experience, according to Finnish historian Auvo Kostiainen, the Finns "came into close contact with American labor organizations, and they stuck together with other nationalities on the Mesabi Range." 207 The lessons of co-operative labor organization became firmly entrenched in the collective consciousness of Finnish immigrant organizations such as the FSF and the FSF's close association with the Wobblies led many Finnish immigrant socialists to gradually become Finnish-American Wobblies who were receptive to seeing class struggle as an international fight and not an intra-ethnic struggle for industrial respect. ${ }^{208}$

Thus, the unification of labor in the 1916 Strike occurred at several levels. On one level, the IWW operated as a national rallying institution and Minnesota's socialist-

\footnotetext{
${ }^{207}$ Kostianen, The Forging of Finnish-American Communism, 37. 208 Ibid.
} 
unionist Finns provided a regional organization that could provide a grassroots organizational foundation and social spaces to serve local striking populations. While the IWW provided the funds, muscle, and prestige of a nationwide union, the FSF and their social spaces of discontent provided several strategic loci for agitation and organization. ${ }^{209}$ The most important expression of this action were the physical structures that acted as meeting spaces for inter-ethnic organization. Finnish immigrants and their social spaces became important rallying points for the IWW's efforts at creating cultural solidarity within a previously divided working-class culture.

While the action of the 1916 Strike was spread out all across the Mesabi Range's seventy-mile length, there was a main "stage." This central venue of strike activity was the well-adorned Socialist Opera House in Virginia, Minnesota. A brick structure with ornate architectural elements, the Socialist Opera House was designed to impart the credibility, permanence, and stability of the FSF on a landscape dominated by mining companies. Previously the home of Finnish immigrant cultural endeavors, the Opera House became a focal point of multi-ethnic organizational efforts during the strike. While the strike was a bloody and sometimes dirty affair that played out on the Iron Ranges' industrial landscape, the Socialist Opera House was a contradiction to the strike's grizzled setting. This was most evident starting with the building's architecture, inside and out. Historian James A. Roe wrote of the Socialist Opera House, "In their success, however, the builders brought together a curiously contradictory assemblage of images and ideals. Even the name 'Socialist Opera'--so boldly displayed on the façade--joins

${ }^{209}$ Kostianen, The Forging of Finnish-American Communism, 36-37. 
elements from two usually differing worlds; the working class ethic of socialism and the high culture of opera." 210 The Opera House was so ornate and skillfully designed the conservative press in Virginia even remarked that the Opera House was "one of the most substantial structures on the Range, modern in every detail." ${ }^{211}$ In a 1913 Työmies newspaper article A.F. Heiskanen wrote of the Opera House, "our new hall...is the epitome of the struggle up to this time of the Virginia working class." ${ }^{212}$ To some, the hall and the refinement of socialism, which the Opera House symbolically represented, was a source of pride and organizational affirmation.

Whether dogmatic socialists liked it or not, the Socialist Opera House and some of its cultural activities were less about strident working-class culture and more about recreation. Perhaps this was an innovative direction as the fancy opera house stood as a motivational symbol and source of great revenue for the socialist-unionist movement. Additionally, and more covertly, the Opera House and its cultural activities beckoned as an enticement for non-socialists to walk through hall doors and hear the proletarian message. This was purposeful. As Roe deduced in his article, the mission of the Virginia Workers' Organization, builders of the Opera House, was to get people in the seats and then convert them, "It was possible to draw audiences unaware of the movement to hear agitators' speeches, poems and songs and such material with which it was possible to elevate their knowledge." 213 The Opera House opened on April 13, 1913, with over 800

\footnotetext{
${ }^{210}$ James A. Roe, "Virginia, Minnesota's Socialist Opera: Showplace of Iron Range Radicalism" in Finnish Americana: A Journal of Finnish American History and Culture, Vol. 9, edited by Michael Karni, (New Brighton, Minn.: Finnish Americana, 1992), 38.

211 Ibid.

212 Roe, "Virginia, Minnesota’s Socialist Opera House," 39.

213 Roe, "Virginia, Minnesota’s Socialist Opera House," 38.
} 
people enjoying a play by Goethe. Mixed in with subsequent farcical comedies and high tech bourgeois stage productions were educational and dramatic plays designed to elevate class-consciousness and create proletarian solidarity. ${ }^{214}$

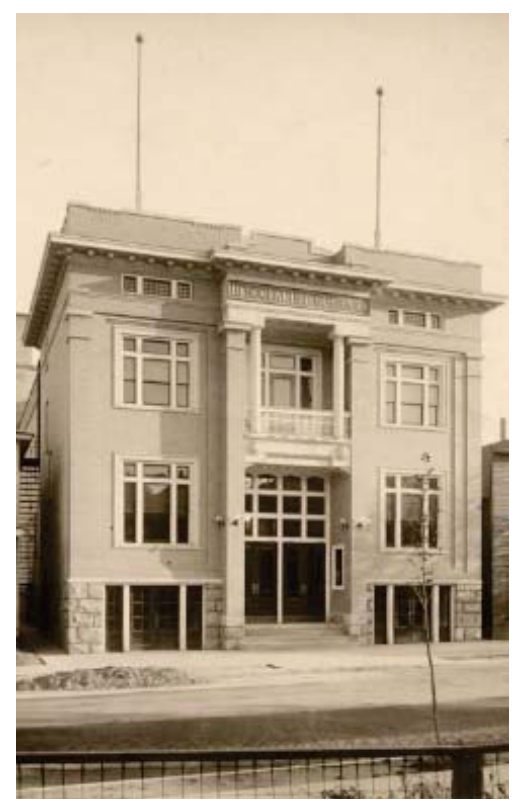

Figure 6.1-Exterior view of the Socialist Opera House, Virginia, Minnesota-Immigration History Research Center

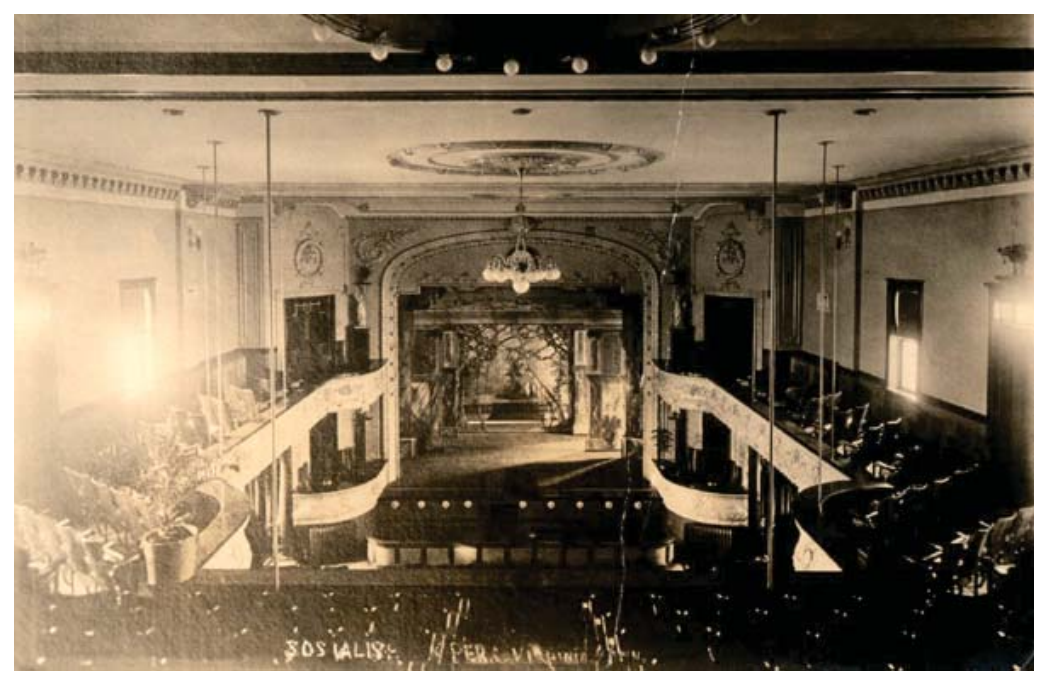

Figure 6.2-Interior photo of the Socialist Opera House, Virginia, Minnesota-Immigration History Research Center

${ }^{214}$ Roe, "Virginia, Minnesota’s Socialist Opera House," 41. 
Regardless of form and function, the Opera House became the central meeting place for IWW organizers during the 1916 Strike and housed everything from local union offices to official meetings of the IWW's administration to raucous rallies of the rankand-file. Fiery oratory by the likes of Carlo Tresca and Elizabeth Gurley Flynn echoed in the hall's rafters, while out of work mineworkers filled the ornate hall's seats before mobilization in strike watches and parades. The artful ornamentation of the Socialist Opera House at times clashed with the revolutionary goals of the rugged IWW. Unlike most modest, yet functional halls and theaters such as the handmade and improvised Nashwauk Hall, the Socialist Opera House's design competed architecturally with American vaudeville theaters. The Opera House was a place that dazzled with its excessive ornamentation and visually intended audiences to escape their ordinary worlds. ${ }^{215}$ It was this ordinary, material world, however, that the 1916 Strike was centered in and the Opera House's fancy chandelier and ornate woodwork likely contrasted the growing number of haggard out of work striking mineworkers.

For a description of the Opera House's interior and an inside look at the material culture of the building, an oral history with Daisy Walkama who grew up in the comfort of the Opera House's cultural activities, sheds light on the historic space. She remembered, "the Socialist Opera House as being very grand, even in the late 1920s and early 1930s [when she attended cultural activities there]." Daisy remembered that the Opera House had a beautiful multi-purpose room on the main floor. The main floor had wood floors with moveable wooden folding chairs, so the seating could be moved for

${ }^{215}$ Roe, "Virginia, Minnesota's Socialist Opera House," 38-40. 
gymnastics practice. The side walls of the main floor had box seating, while balcony seating hung over the main floor. The basement had a kitchen and a dining room for serving kavia and pulla (coffee and Finnish bread). The Opera House's bathrooms also served as changing rooms for the actors who performed in the Opera House's plays and musicals. ${ }^{216}$

While the Virginia Socialist Opera House was nominally official strike headquarters, the Hibbing Workers Hall was equally important to organizational efforts on the Minnesota Iron Ranges. Hibbing, the city, was especially important to the Finnish immigrant socialist-unionist movement. In 1906, formerly unaffiliated Finnish immigrant socialist locals in America came together in Hibbing and voted to create and join the federation of socialist organizations that became known as the FSF. The FSF became the first and largest foreign-language party within the Socialist Party of America and Hibbing was its birthplace. ${ }^{217}$

For the IWW, the Hibbing hall was mostly important because it was located in Hibbing — largest metropolitan area on the Ranges. The hall, its members, and activities were the locus of action for striking workers on the western edges of the Mesabi Range, which included the tightly controlled Itasca County iron mines. Located in what became known as North Hibbing, the hall was a stately, wood-sided balloon framed structure, which was utilitarian in all of its appurtenances. Located on land once owned by the Oliver, the Workers' Hall was not nearly as ornate as Virginia's Socialist Opera House

\footnotetext{
${ }^{216}$ Daisy Nelson-Walkama, “Oral History Interview,” July 20, 2006, conducted by Gary Kaunonen, Finnish American Historical Archive, Hancock, Michigan.

${ }^{217}$ The Wage Slave, May 22, 1908.
} 
and was perhaps more akin to a traditionally-conceived working-class space.

Nevertheless, the Hibbing hall's activities, usage of interior space, and physical size mirrored those of the Opera House. Plays were an important way to express ideology and bring in revenue, but during the 1916 Strike the Workers' Hall gained great importance as a meeting area for strikers. The hall's importance to Finnish immigrant socialists, however, went back to 1909.

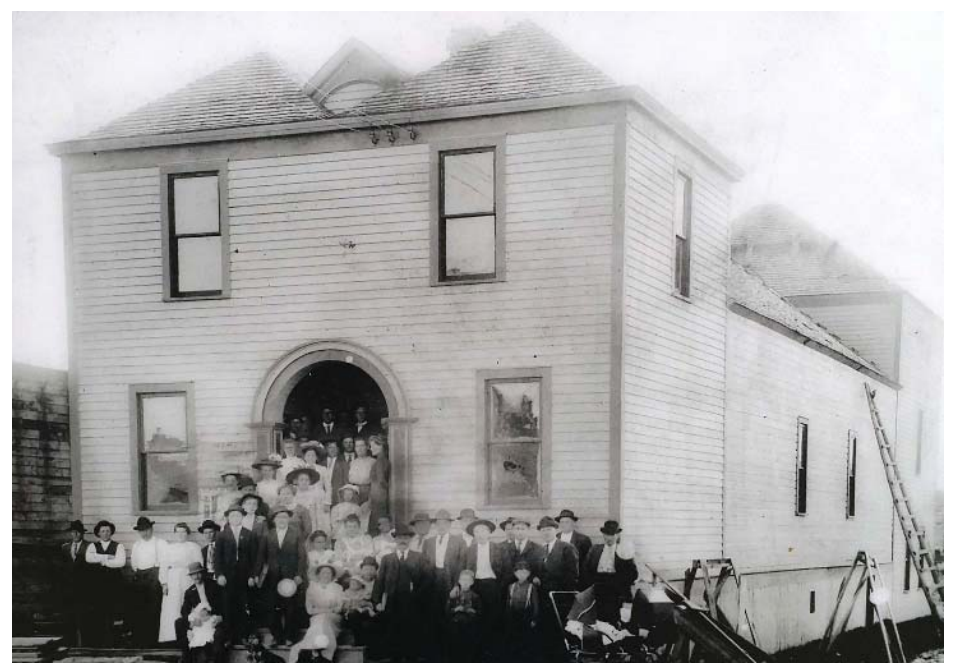

Figure 6.3--Exterior view of the Hibbing Workers Hall--North Hibbing Walking Tour Panel

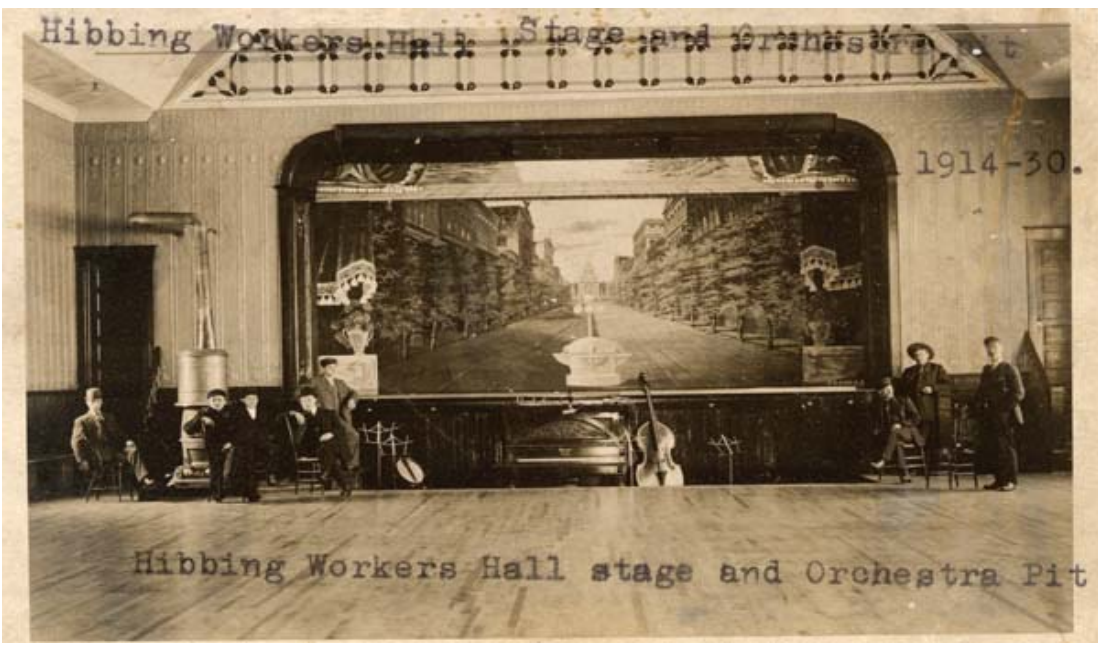

Figure 6.4-Interior photo of the Hibbing Workers Hall stage and scenery-Immigration History Research Center 


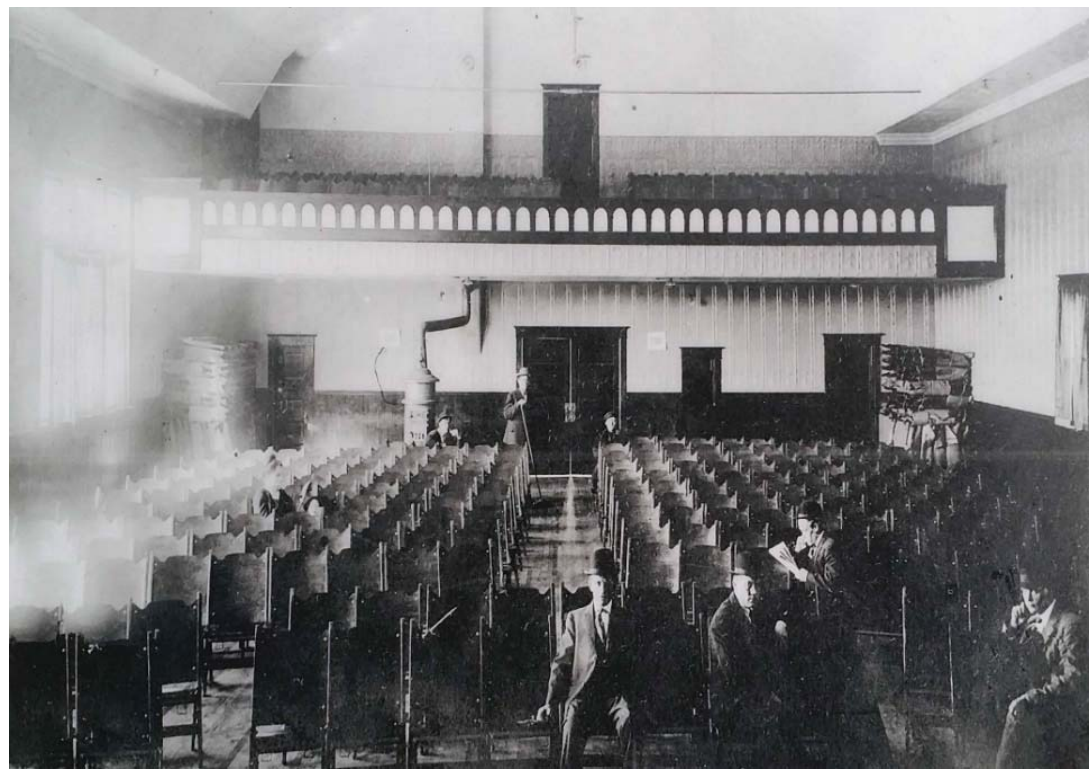

Figure 6.5-Interior photo of the Hibbing Workers Hall seating and balcony_North Hibbing Walking Tour Panel

For the hall's grand opening, the Hibbing FSF local decided to overlap their festivities with a New Year's Eve (1909) daylong celebration. For the opening affairs, the local scheduled a speech by Leo Laukki, professor at the Work Peoples' College, a reading by Finnish immigrant poet Aku Päiviö, and another speech by Hibbing Local member Wilho Leikkas. That night a performance of Gustaf von Nurmer's Elinan Surma (The Death of Elina) was scheduled. The cast of characters was long and included eighteen actors to cover all the parts. One of the play's characters was Vарри or Freedom, likely a tip of the cap to the industrial democracy called for the by IWW. ${ }^{218}$

\section{Melodic Voices of Revolution in Fiery Spaces of Discontent}

During the 1916 Strike two powerful cultural expressions coalesced in Finnish immigrant built social halls. The locally robust Finnish immigrant socialist-unionist

${ }^{218}$ Työmies, December 1910. 
organizations, replete with a vibrant hall culture, met with the vibrant and melodic culture of the IWW. The two groups were likeminded comrades and one familiar expression of culture united the organizations_-singing. More than any other expression of culture in social spaces of discontent, singing was the shared experience for both FSF and IWW members. As a form of cultural expression, music has been an intangible part of the working-class experience. The Wobblies were known as the "Singing Union" and the Finnish immigrant experience with industrial America highlights the power of verse set to music.
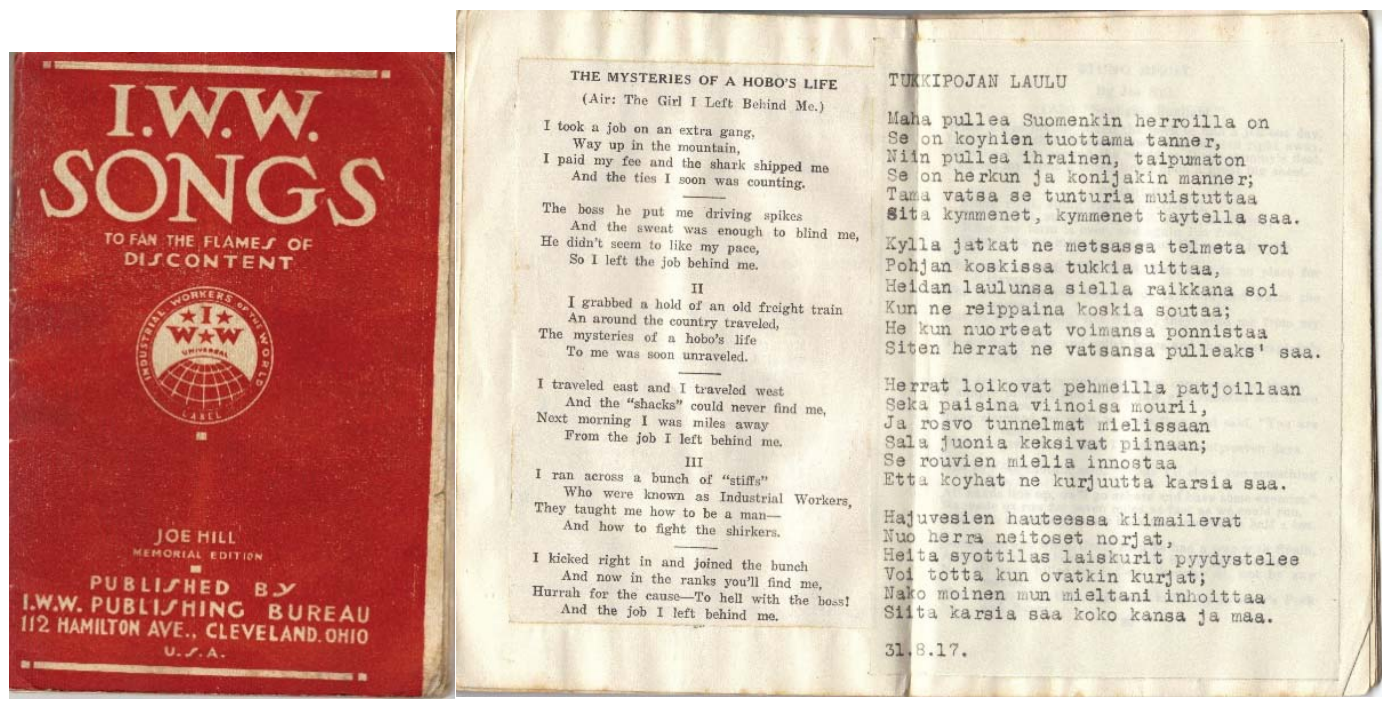

Figure 6.6-Image of "Joe Hill Memorial Edition" of the Little Red Songbook, notice that the book's owner pasted in copies of preferred songs, one being in the Finnish language-author's collection

In most, if not all, Finn Halls across Minnesota's Iron Ranges, songs of industrial revolt and protest filled the air of halls up to the rafters with conceptions of what it meant to be class-conscious social actors. Some of these songs came with the immigrants from Finland, but increasingly over time, the songs sung in immigrant Finn Halls were derivations of IWW songs sung in Finnish with borrowed words from the American 
working-class. Some members knew the songs by heart, but others learned the songs from songbooks published by the Finnish immigrant-founded Workers Socialist Publishing Company, which became a publishing arm of the IWW. In this immigrant press songbooks took on a critical purpose as transmitters of cultural values and both Finnish-language and English-language songbooks were treated with a type of sanctity that resembled religious hymnals. The Wobbly songbook pictured above is an example of the personal connections that were established between songbook owners and the material culture of the industrial union. The aforementioned songbook is also unique because its owner so strongly felt the intersectionality between his Finnish roots and the Wobblies that he or she pasted Finnish-language songs into his or her English-language songbook. This type of cross-cultural expression was an important amalgamation that deserves additional emphasis because singing and songs were one of the most proficient ways of transmitting American working-class culture, identity, and ideology to an immigrant people. Once in America, the traditions of the Old World came into direct contact with other cultures and musical traditions. Finns in America were inevitably influenced by other working-class groups and their music was surely shaped by such interactions as intersectional members of an immigrant and an American working-class group.

The multitude of intersections between Finns in America and conceptions of what it meant to be a part of the American working-class demonstrated the interplay between culture, organized labor, and class-conscious literacy. As instrumental communicators of culture, songs have the power to teach, to educate, those who did not have the means for formal education. The songs danced to in Finn Halls, caterwauled in boarding houses, 
woods, and lumber camps, and sung in part harmonies around a kerosene lamp in the family kitchen fostered a type of class conscious literacy that could not be bought at the finest collegiate institution, divined by the most pious religious organization, or taught at the most bureaucratic primary school. Finnish immigrant songs, as well as the musical history of other immigrant groups, related what it was to be working-class giving expression to the joy, pain, triumph, and struggle of newly American, yet somehow "foreign" toilers.

Like other immigrant groups in America, the Finnish immigrant population had little say in their future (or past) education. As discussed in Chapter 3, education and literacy efforts were enforced via systems of dominant bureaucracy and the working-class was told what they were expected to learn. As the work of others lined the pockets of the rich and as public education was influenced by industry and bourgeois statist structure, there was little concern for providing the masses a means to understand their culture, history, and plight. So, for members of the working-class, literacy programs and educational opportunities free from others' class backgrounds had to be created in accessible, unique, and sometimes clandestine ways. Working-class songs provided an excellent platform to pass along such a system of literacy via cultural expression that was free of class control. As a note on style, the IWW's musical culture contained a unique sense of subversive character regarding the struggles of toilers. This sense of irreverence came through in things such as political cartoons, but perhaps even more so in song. IWW songs, often described in proper society as boorish, used this sense of humor, sarcasm, and satire to create an often cheeky and irreverent musical culture that endeared listeners and imbued them with a sense of power through mockery. Songs were an easy 
method of transmitting elements of the IWW's sarcastic, vibrant, and whimsical cultural apparatus and Finnish immigrants heartily embraced this cultural expression. In turn, Finn Halls became the social space most affected and appreciated in this working-class cultural exchange.

In summing up this chapter of the dissertation, the importance of material culture in the formation of working-class identity cannot be overstated. Social spaces and songbooks were important transmitters of such cultural treasure. The extensive printing of IWW songbooks in myriad languages supported the retention and preservation of such working-class overtures. The oft-memorialized songbooks of the IWW were a significant feature of proletarian cultural activities. The songs contained in these songbooks were an essential component to the process of crafting literacy in the working-class because even if a worker could not read the long philosophical tracts of Bakunin or Marx, songs to fan the flames of discontent gave immigrants and their American fellow workers an opportunity, at the very least, to understand the basics of industrial unionism and collective action. It was in this lyrical expression of culture that the IWW's ideology and revolutionary message existed in its most effective way. These important cultural disseminators were most often received by a multi-ethnic audience during the 1916 Strike in the revered Finn Hall. Thus, the importance of the Finn Hall to the cultural imperatives of the 1916 Strike was equally significant. The halls were local loci of organization that united immigrant workers from numerous nations and structured the revolt against Minnesota iron ore companies.

Utilizing an effective cultural apparatus in the years before the strike, the IWW had effectively fanned the flames of discontent on the Minnesota Iron Ranges. By 1916, 214 
the Ranges' multi-ethnic workforce was prepared to assert their collective voices like never before. A strike was coming. And, for the IWW it was time to put the lessons they had learned from past experiences into action. The continuing effective transmission of their culture, identity, ideology, and revolutionary goals to the Ranges' working masses was imperative and this examination of Wobbly rhetoric and a labor history of the 1916 Strike is the subject of this dissertation's last section. 


\section{Section: Rhetorical Studies and Labor History}

\section{A Solidarity-inspired History Vignette: Jimmy John's Subs vs. the Modern IWW}

While the IWW faced severe repression after the 1916 Strike and almost ceased to exist as a labor union it is now undergoing a resurgence. The $21^{\text {st }}$ century iteration of the IWW is by no means on par with the numbers or influence of the pre-World War I IWW, but the union has carved out an important niche for itself in the organization of service industry workers. As one of the only unions attempting to organize unskilled workers in the food service industry, the IWW is again seeking to organize the unorganizable. Just as it was extending membership to immigrants, women, and people of color in 1916, the IWW of contemporary times is extending membership to the same working populations. This success in organizing those in the service sectors has pit the IWW against some of the most popular franchises in United States history. In efforts to bring fair wages and healthy working conditions to fast food sectors the IWW has sought to organize workers at Starbucks, Subway, and Jimmy Johns Subs. The struggle to organize Jimmy John's has been especially rigorous.

Similar to the labor troubles in 1916, Minnesota has taken center stage in the IWW's assault on Jimmy John's in the present day. Workers from Minneapolis area Jimmy John's restaurants have run afoul of management in their attempts to assure that sick employees are not making sandwiches. As one article featured on the IWW's web site chronicled on April 24, 2012, "picket lines will popped up around Jimmy John's at noon today as sandwich workers and supporters from Occupy Minneapolis and local labor unions sought to persuade franchise owners Mike and Rob Mulligan to comply with a judge's order to reinstate six workers illegally fired for blowing the whistle on company 
policies which expose customers to sandwiches made by sick workers." ${ }^{219}$ According to the fired IWW workers, Jimmy John's owners required workers to come into work when showing symptoms of a viral respiratory infection. This policy came under scrutiny especially when global pandemic scares related to the H1N1 virus were in continuous rotation on the 24-hour news channels.

Workers balked at the company's policies and sought the advice of the IWW in organizing Jimmy John's workers to fight the "sickening" working conditions. As workers began their organizational push, Jimmy John's owners, the Mulligan brothers, fired six of the labor activists. The IWW, and the fired workers, took the claim to the National Labor Relations Board and ended up suing the Mulligan brothers for the reinstatement of the fired workers' jobs. Similar to mining companies in early $20^{\text {th }}$ century Minnesota, the Mulligan's fought the suit because they likely wanted to avoid setting a precedent for future labor-management relations. In the meantime, the Minnesota Department of Health had reported "three outbreaks of foodborne illness in the past five years at the franchise, due in part to sick workers." As a matter of public health, the moral high ground rested with the fired workers, but a more sinister side to the Mulligan brother's management was revealed with Mike Mulligan admitted under oath that "he had fired the six workers because he perceived them as the "leaders and developers' of a unionization effort. Mulligan's credibility was further eroded when he testified to intentionally lying about the franchise's food safety record to the press."220

\footnotetext{
${ }^{219}$ Industrial Workers of the World, “Update of Jimmy John’s Struggle,” accessed at www.iww.org, on November 15, 2014.

${ }^{220}$ Ibid.
} 
Drawing on the IWW's steadfast direct action ideology of yesteryear, co-workers, families, and friends of the fired employees joined together and took their message to the streets. Using material culture as a means to educate the public regarding the fired workers' plights, the labor activists posted " 3,000 copies of a poster explaining that workers are forced to make sandwiches while sick." 221 This media campaign garnered regional and national media attention and prompted the Mulligan brothers to change their sick-leave policy. As the old Wobbly adage maintains, "Direct Action Gets the Goods." In this case, the IWW established a presence at Jimmy John's restaurants across the country and the fight to organize low wage workers in the food service sector is a staple of the contemporary IWW's organizing work.

\section{Section Introduction}

The Wobblies, and the Minnesota Iron Ranges' striking workers, were up against great odds in organizing the 1916 Strike. The Oliver Iron Mining Company, a subsidiary of U.S. Steel, or also known simply as the Steel Trust to those on the Ranges, had millions of dollars to spend on breaking the strike. Additionally, tens of other well-heeled iron ore operators known as the Independents looked to Oliver's leadership in this time of industrial turmoil and pledged funds and people to rid the Ranges of the IWW. The Steel Trust had a long reach and as this section proffers their influence went all the way to the Minnesota Governor's office. In addition to the barriers of organization put forth by mining companies, perhaps the IWW's most difficult hurdle in bringing about a large

${ }^{221}$ Ibid. 
successful labor action was that the union sought to organize immigrant mineworkers from many different nations — none of which identified English as a first language.

The fight to organize and lead strikers during the 1916 labor upheaval was certainly going to be an uphill battle that would test the effectiveness of the IWW's abilities to successfully communicate their message of revolutionary industrial unionism to a diverse and somewhat divided, spatially scattered working-class population. This ability to effectively communicate with the Ranges' working masses, the consequences of this communication, and the chronicling of these efforts during the strike is the subject of this section. Therefore, the chapters contained in this section provide a labor history of the strike that incorporates an examination of the IWW's effective use of rhetoric to persuade the Ranges' working-class that they could match the power of million dollar mining companies in the struggle for industrial democracy.

In this ultimate David versus Goliath-style showdown between labor and capital, the IWW employed the use of rhetoric in innovative ways. This dissertation argues that the IWW's skillful use of rhetoric during the 1916 Strike was guided by a cunning intelligence, or metis, which enabled the IWW's multi-modal communication efforts to persuade the area's immigrant workers to recognize three vital concepts: 1) understand the technical definitions and goals of revolutionary industrial unionism by distilling the technical language of ideology into concise texts and visual interpretations of key concepts; 2) recognize their plight as exploited industrial workers and know that there were methods to protest for better working conditions and effect positive change; and 3) envision themselves as part of a unified international working class that sought solidarity with other union members who were known as, in IWW lingo, a Fellow Worker. 
The study of the IWW's metis in interactions with employers and its rank-and-file on Minnesota's Iron Ranges is an interpretation forwarded by this dissertation. None of the IWW's organizers walked into Virginia's Socialist Opera House and announced to the crowd of immigrant workers that they would use metis to defeat the "bosses." In their seminal work on metis, Cunning Intelligence in Greek Culture and Society, Marcel Detienne and Jean-Pierre Vernant argue:

[metis is] a type of intelligence of thought, a way of knowing; it implies a complex but very coherent body of mental attitudes and intellectual behaviour which combine flair, wisdom, forethought, subtlety of mind, deception, resourcefulness, vigilance, opportunism, various skills, and experience acquired over the years. It is applied to situations which are transient, shifting, disconcerting and ambiguous, situations, which do not lend themselves to precise measurement, exact calculation or rigorous logic. ${ }^{222}$

Thus, metis is a somewhat intangible and shifting concept, but one that Dr. Robert R. Johnson, in his book User-centered Technology: A Rhetorical Theory for Computers and other Mundane Artifacts, argues has a direct connection to a practical knowledge that allows rhetors to connect with an audience in concrete, everyday terms. As Johnson wrote, "practical knowledge, especially knowledge of making aimed at some end, was seen as being very important to the Greek mind." 223 The same appears to be true with the

\footnotetext{
${ }^{222}$ Marcel Detienne and Jean-Pierre Vernant, Cunning Intelligence in Greek Culture and Society, translated from the French by Janet Lloyd, (Chicago: University of Chicago Press, 1991), 3-4.

${ }^{223}$ Robert R. Johnson, User-centered Technology: A Rhetorical Theory for Computers and Other Mundane Artifacts, SUNY Series, Studies in Scientific and Technical Communication, (New York: State University of New York Press, 1998), 54-55.
} 
IWW. This perhaps sets the IWW's rhetoric apart from other United States labor unions of the time and other revolutionary theorists past and present. The IWW hoped to impart an action-based practical knowledge to its membership; one that would allow Fellow Workers to engage in direct action tactics, while still understanding the ideological significance of such tactics in the on-going class struggle.

Furthermore, Wobbly rhetoric was application based and because of the IWW's decentralization and commitment to rank-and-file power, its attempts at effective communication had become uniquely user-centered over time. With the practical experience of labor action successes like the Lawrence, Massachusetts, Textile Strike and disappointments such as the Patterson, New Jersey, Silk Strike in their past, similarly forged in the interests of unskilled immigrant workers, the IWW purposefully geared organizational drives and media offerings to the multi-ethnic, unskilled workers they were representing on the Minnesota Iron Ranges. The IWW's use of rhetorical appeals were crafted out of a direct to connection to the practical but revolutionary goals they were espousing in the union's cartoons, literature, and street speeches. The primary example of this practice-based application of the IWW's ideology was the strike as the ultimate form of industrial sabotage. Transmitting this ideological construct directly to the rank-and-file often meant that the IWW had to communicate with their members on the rank-and-file's own terms, and not in the jargon of sweeping revolutionary didacticism.

The IWW's utilization of metis while organizing striking workers before and during the strike fits many of Detienne and Vernant's and Johnson's characterizations of the term. The IWW rushed to the Ranges and had to adapt to a developing situation in 
early June 1916. Workers were ready to revolt but had little understanding of how to organize a mass labor action. From past experiences the Wobblies had a set of organization methods and tools that could help to guide workers in taking on the "bosses." One such method was creating opportunities for interaction with the Ranges' polyglot of languages. The IWW's past experiences in Lawrence, Patterson, and even on Minnesota's Iron Ranges in 1907, gave the Wobblies the foresight to use local and national organizers who spoke almost all of the languages of the Ranges' striking workers. In addition to creating a multi-lingual cadre of organizers, the IWW utilized the emotive influence of creative cartoonists, labor power of printing "pressmen," quickwitted sarcasm of passionate writers, and the skillful presentation methods of orators such as Elizabeth Gurley Flynn to persuade Range audiences. Thus, the Wobblies' use of metis on the Range was ubiquitous, though never formally understood as a technical part of their organizational strategies.

Another such strategy employed by the IWW was the use of rhetorically appropriate methods to persuade working-class audiences. This section of the dissertation, and especially Chapter 7, will examine the commonly referred to "rhetorical triangle," which highlights the relationship between author, audience, and text, to help explicate the IWW's use of Aristotle's three basic rhetorical appeals: ethos, logos, and pathos. The IWW's appeals to their working-class audience often elicited an emotional response and commitment to the IWW's organizational goals, but underlying these emotionally charged appeals was a strong sense of credibility and logical development, which guided the IWW's multi-modal supplications to its working-class audience. It was the effective combination of all three appeals that garnered the most productive 
application of the IWW's intended message. Connecting the hearts (pathos) and minds (logos) of the rank-and-file with a skillfully delivered message by a credible (ethos) labor organization created a powerful argument that positively affected the attitudes of the IWW's rank-and-file.

The analysis of the interactions between audience, author, and text via the three appeals will constitute a rhetorical analysis of the IWW's attempt to effectively communicate with its intended audience. In his article, "Rhetorical Analysis: Understanding How Texts Persuade Readers,” Jack Selzer argues that a rhetorical analysis endeavors to "understand how people within specific social situations attempt to influence others through language." The IWW's attempts to persuade their rank-and-file audience were not only language based, but also included multi-modal methods and formats to enjoin members in the working-class struggle. Selzer argues that limiting rhetorical analyses to assessments of language short-shrifts the discipline. He concludes that rhetorical analyses should not, "[occur] just through language. Rhetoricians today attempt to understand better every kind of important symbolic action-speeches and articles, yes, but also architecture [and other visual media]." ${ }^{224}$ Selzer's advocacy of expanding rhetorical analyses to understand other forms of symbolic action dovetails nicely with the projects of cultural history and material culture, which seek to examine the symbolic artifacts of human attitudes, beliefs, and behavior.

\footnotetext{
${ }^{224}$ Jack Selzer, "Rhetorical Analysis: Understanding How Texts Persuade Readers," in What Writing Does and How it Does It: An Introduction to Analyzing Texts and Textual Practices, editors Charles Bazerman and Paul Pryor, (London: Routledge, 2003), 280-281. Italics are from Selzer's own writing.
} 
In addition to the three most common parts of a rhetorical analysis, this dissertation will add a fourth term when doing rhetorical analyses of the IWW's communications with striking workers: lexis. For the purposes of this dissertation, lexis will be used in an adapted manner to help discern the style or method of delivery for the IWW's interactions with its rank-and-file. From Rhetoric, Aristotle intended lexis to be a method of analyzing the delivery or styles employed while speaking to an audience. In this dissertation's rhetorical analyses of the IWW during the strike, lexis will refer to the whole method of delivery in IWW communications with working-class audiences. Thus, a text such as an IWW treatise on the technical aspects of industrial unionism will be examined as to its appeals to ethos, logos, and pathos, as well as the text's lexis-is it printed on durable paper, what colors are used on the front and back covers, or how are images distributed throughout the artifact. In this manner, lexis will be utilized as a tool to determine the delivery or style of an artifact, message, or oration. While ethos, logos, and pathos appeals might accurately describe the persuasive aspects of a technical treatise on industrial unionism, a study of the item's lexis is employed to explicate the tangible and/or intangible significance of the ways in which the cultural artifact is presented to an audience.

The IWW and its multi-modal efforts at effective communication provide exceptional models of study in the historical use of modern rhetoric. In its short history prior to the 1916 Strike, the IWW had developed a dynamic and vibrant cultural apparatus. This expression of these cultural artifacts, tangible and intangible, included songs, art, street speaking, strike placards, and literary and theoretical texts. The IWW created and nurtured a pulsating popular culture that mixed didactic message via a 
stylized medium to foster a unique sense of radical working-class culture. Especially influential were the IWW's images of discontent. These images created an immediate effect that visually represented common, everyday themes of class struggle, solidarity, and working class emancipation.

Working in tandem with graphic images, the IWW was a deft producer of print media. In these texts, the IWW explained complex ideas of industrial union ideology. For Dr. William DeGenaro the purpose of working-class publications are to "explicate the class struggle as it exists in rhetorical texts, paying attention to what rhetors say regarding social class and attempting to situate the discourse of those rhetors in their contemporary context." Similar to the IWW's own agitators in 1916, De Genaro argues that "workingclass rhetorics agitate and antagonize the static words on pages of rhetorical texts."225 The following chapters will delve into the IWW's cunning and skillful use of workingclass rhetorics to communicate with a very diverse rank-and-file during the strike. While the IWW was skillfully employing such rhetorical appeals in their communication strategies, mining companies and Progressive politicians were fighting for the same hearts and minds. Chapter 9 highlights the rhetorical appeals made by those who wished to checkmate the IWW's revolutionary working-class perspectives.

While Chapters 7 and 9 primarily examine the IWW's rhetorical strategies, Chapter 8 is a candid critical history of the efforts to silence the voice of the IWW and its striking workers by mining company managers, law enforcement officials, and even Minnesota's Governor. While the IWW forged its rhetorical appeals in a bitterly

${ }^{225}$ DeGenaro, Who Says?, 6-7. 
contested industrial and social landscape, this section also chronicles the labor history of this epic struggle between labor and management. The research and writing in this dissertation is very much a product of the New Labor History's attempts to expand the narrative past somewhat limiting discussions of shop floor economics and Anglo-centric expressions of craft and trade unionism. In an attempt to place such a perspective in context, this section summary looks to David Brody's article, “The Old Labor History and the New: In Search of an American Working Class," as a scholarly work to locate this dissertation.

In his article, Brody weaves his way through the United States academic discipline of labor history highlighting the chronological movement of labor history from one dominated by conservative labor economists to a New Labor History influenced heavily by the British Marxist historians E.P. Thompson and E.J. Hobsbawm. From the influences of the British historians, Brody points to the pioneering work of Herbert Gutman as the catalyst for a new, ideologically charged, culturally attuned "bottom-up" labor history.

Brody begins his article by examining the post-World War II and early 1950s Wisconsin School of labor history guided by J.K. Common. This school examined, almost exclusively, trade unionism. As part of this examination of American labor by economists turned historians, Brody contended that, "collective action by workers constituted an inadmissible interference with the free market" ${ }^{, 26}$ Labor history in this era, the Old Labor History, was light on the actual laborers, instead steering the discipline into

\footnotetext{
${ }^{226}$ David Brody, "The Old Labor History and the New: In Search of an American Working Class," in Labor History, Vol. 20, (London: Routledge, 1979), 112.
} 
an analysis of American capitalist values to the detrimental analysis of workers and the struggle to construct a truly working-class labor history.

Brody then moves into discussion of two waves in the New Labor History, stemming from Gutman's work. Gutman's pioneering work led to the formation of American labor history that borrowed from the foundations of the British Marxist historians and centered on explorations of the workers' whole life (economic, cultural, social) versus the relationship of workers to capital. Brody termed this the "democratization" of the field and included three main components: 1) breaking the narrow confines of institutional and narrative history; 2) opening multi-causal analysis; and 3) the development of scholarly superstructure. ${ }^{227}$ From these groundbreaking works, Brody moves into the then current, second generation of American labor history, which includes works by Melvin Dubofsky, Eric Foner, and others. This, preceded by Gutman's work, was the movement to create an Americanized version of E.P. Thompson's "history from below" or "history of the inarticulate." It is this generalized methodology that guides not only this section, but the entirety of the dissertation.

${ }^{227}$ Brody, "The Old Labor History...," 112-113. 


\section{Chapter 7: Fiery Rhetoric on the Ranges}

\section{Chapter Introduction: Rhetoric, Culture, and the IWW}

As Aristotle first identified, the skillful use of rhetoric can be a powerful tool in persuading audiences. From the historic record it is unclear, but perhaps doubtful that any of the IWW's organizers had formal training or schooling in the application of compositional strategies or rhetorical communication tactics. Instead of studying the effective use of rhetoric, the IWW's leaders and organizers lived it. This previous experience in communicating with the United States' working masses gave a type of education that was more valuable, more instructive, than any text book on rhetoric could ever offer. Perhaps most importantly, by 1916 the IWW learned in its short history as a labor union that each struggle with capitalist bosses was a new fight, but that past clashes with capitalists always held some type of a lesson. In this sense, this chapter on the rhetorical strategies of the IWW during the 1916 Strike is an examination of the IWW's adaptation and evolution as communicators of a revolutionary message in a specific time and place.

This chapter seeks to build on this dissertation's previous analysis of the IWW's members as cultural actors by analyzing multi-media materials produced specifically for the 1916 Strike. The rush to organize striking mineworkers on the Minnesota Iron Ranges taxed the IWW's cultural apparatuses. Additionally, the union was taking on one of the most powerful, if not the most powerful corporation in the United States, US Steel, or as the enterprise was more colloquially known - the Steel Trust. The IWW and their mostly immigrant rank-and-filers were up against great odds, but the passion that had sustained the IWW's commitment to revolutionary industrial unionism would guide the union in its 
efforts to communicate with the Ranges' working-classes. The great test for the IWW, then, was successfully communicating this passion via multiple media sources in an effective manner. This chapter analyzes those efforts in an attempt to chronicle the IWW as revolutionary rhetors communicating with a complex working-class audience.

\section{Showdown: The IWW, the Mining Companies, and the 1916 Strike}

Founded in Chicago in 1905, the IWW exemplified a radical vision of a labor organization formed and structured expressly to seize the means of production from capitalists. This was the revolutionary perspective unleashed on Minnesota's Iron Ranges. Revolutionary in that such an ideology ran against the economic interests of United States capitalists, but also because the IWW attempted to situate transformative power squarely in the hands of workers. The union was decentralized, and unlike industry that was hierarchical from its outset, the IWW attempted to place control in the hands of the rank-and-file. Emphasizing class struggle and industrial solidarity as the core aspects in worker revolt, the Wobblies maintained that human labor power was the source of all wealth.

While the IWW was squarely in opposition to industrial "bosses," it was also in conflict with conservative craft and trades unions such as those in the fold of the American Federation of Labor (AFL). The A.F. of L. was reticent to organize women and non-English speaking immigrant ethnicities. The Wobblies jumped into the fray and primarily attempted to organize those deemed unorganizable by the AFL's union bureaucrats. Thus, the IWW was attacking and under attack from multiple interests in industry. This tension existed during the IWW's efforts to organize workers on Minnesota's Iron Ranges, and the rhetorical strategies used by the IWW sought to portray 
immigrant workers as one body that was able to confront, chide, and chagrin the Ranges' multi-million dollar mining companies and conservative unionists. Almost predictably, the rhetoric used against the IWW featured attacks on the "foreign" and outsider status of the IWW as well as those it sought to unionize. Wrapped up in these deliberate, partisan, and passionate rhetorical struggles was a region on the brink, as Minnesota's largest confrontation between organized labor and capital began and the IWW and mining companies squared off in a battle to win the hearts and minds of people in Minnesota's North Country.

The 1916 Strike was a radical extension of the 1913-14 Michigan Copper Strike. After the loss of an especially bitter nine-month strike in Michigan's Keweenaw Peninsula, the Lake Superior basin's workers reevaluated their methods. Many of the same players during the 1913-14 Strike were present for the 1916 Strike. Class-conscious immigrants, labor publications, and tinder-dry, confrontational attitudes between labor and management had not evaporated over the two short years between the end of the 1913-14 Strike and the 1916 Strike. New to the scene was the industrial union representing workers. After calling-off the 1913-14 Strike, the Western Federation of Miners, then a member of the AFL, folded. It would reorganize in 1916 as the International Union of Mine, Mill, and Smelter Workers, but in the all-important showdown between labor and management in 1916, the IWW stepped up to organize immigrant workers on the Minnesota Ranges. The IWW entered the fight and brought with them a talented cadre of experienced organizers: Carlo Tresca, Sam Scarlettt, James Gilday, and others were sent by IWW General Secretary "Big" Bill Haywood to try to catch up to the epic revolt occurring on the Mesabi Iron Range. 
There had been other labor actions on Minnesota's Iron Ranges—many in fact. The most notable was the 1907 Mesabi Range Strike, organized by the WFM, which was then part of the IWW. The 1907 Strike had reached a fevered pitch-immigrant workers on the Mesabi Range had staged mass protests, wholesale shutdowns of numerous mines, and had received national attention. The strike was broken in about a month's time, and Finnish and Italian immigrants, the strike's main ethnic populations, were blacklisted from employment with area mining companies.

Taking the place of blacklisted 1907 strikers were Slavic immigrant strikebreakers brought in to "scab" at area mines; many of these strikebreakers were later hired on by the Oliver and other independent mining companies. By 1908 these "Austrian" workers were disgruntled as well, feeling that they had been used in the 1907 Strike and were discarded after the cessation of strike activities. A letter from one such striker sent to OIMC General Superintendent Charles Trezona documented the feeling of the former strikebreaking workers, "we were good last summer when there was a strike on the Mesabi Range, when you were circulating papers that we should come to the meeting not to strike, truly there we Austrians were honored. Now you have turned your back on us...do not think we are such big fools." ${ }^{228}$ Discontent was building on the Ranges. A 1913 Strike on the Cuyuna Range, not even in existence during the 1907 Strike, perhaps presaged the call to worker revolt in 1916. This strike, commenced in April 1913, saw workers demanding an end to the contract mining system, an eight-hour workday, and

\footnotetext{
228 "The Austrian" to Charles Trezona, "Worker's Correspondence," January 8, 1908, Oliver Iron Mining Company Collection, Minnesota Historical Society, St. Paul, Minnesota, Box 2. 
hospital cost coverage for workers. The 1913 Cuyuna Strike was broken using steadfast anti-labor tactics. $^{229}$

\section{The Fanned Flames of 1916}

The 1916 Minnesota Iron Ore Strike started on June 2, 1916, at the St. James Mine in Aurora, Minnesota. The St. James Mine authorities tried to stop the strike from spreading, but Italian immigrant Joe Greeni fled from Aurora to Virginia, and the strike spread westward across Mesabi. The strike would eventually spread to the Vermilion and Cuyuna Ranges as well. ${ }^{230}$ Local organizers partial to the IWW fanned the flames of the strike until the IWW's regional and national leaders arrived on the scene. The IWW described the push to organize as:

Strikers realized the absolute necessity of a [national] organization. They felt the need of trained speakers and organizers, speaking the different languages of the range. Largely upon the advice of the Finnish miners, the strikers sent word to the nearest organizer of the Industrial Workers of the World in the city of Duluth to come up to the range and help them. Fellow worker [Arthur] Boose, a teamster of Duluth, a capable I.W.W. organizer, started the work of organizing. Soon he got help from the General Headquarters in Chicago...the result of [this] activity was the systematizing of the work in connection with the strike, the issuing of a weekly bulletin, “The Strikers' News,” the starting of a country-wide campaign for financial aid and the distribution of aid to the most needy. ${ }^{231}$

\footnotetext{
${ }^{229}$ Lamppa, Minnesota's Iron Country, 209-210.

${ }^{230}$ Pinola, "Labor and Politics," 28-29.

${ }^{231}$ Industrial Workers of the World, The Startling Story of the Minnesota Miners' Strike on the Mesaba Range 1916, New York: The Minnesota Iron Range Strikers’ Defense Committee, 1916, 10-11. 
With a national, regional, and local organizational force in place, the IWW set up strike headquarters at the Socialist Opera House in Virginia, home of local No. 490. While the Socialist Opera House was the primary center of the strike, Finnish immigrant labor halls across the Mesabi Range served as local centers for organization and agitation. Especially significant in addition to the Socialist Opera House was Hibbing's Workers' Hall, which took on a similar role as strike headquarters for the western end of the Mesabi Range. With Virginia and Hibbing serving as a type of dual headquarters, other halls and social spaces operated as nodes of organization across the Range, transmitting strike news and communiques along the Ranges' disconnected social spaces. ${ }^{232}$

It was no mistake that Virginia became the primary IWW headquarters during the labor conflict. Geographically, Virginia was centrally located in the strike zone when taking into consideration the Vermilion Range's location north of the Mesabi. More important, however, was Virginia's Finnish immigrant population. Haywood and the other Wobbly organizers had been making overtures to the Ranges' immigrant populations since the union's inception in 1905, and as this dissertation has demonstrated, Finnish immigrants were especially receptive to these calls. Thus, the locus of the IWW's activities on the Iron Range were located in the Finnish-immigrant-built Socialist Opera House. In addition to serving as strike administration headquarters, the Socialist Opera House was the location of mass strikers' meetings, the venue for blistering strike speeches, and the beginning and ending of strike parades.

\footnotetext{
232 State of Minnesota, Department of Labor and Industries, Fifteenth Biennial Report, (St. Paul, Minn.: State Printing Office, 1916), 168 and Lamppa, Minnesota's Iron Country, 210-215.
} 


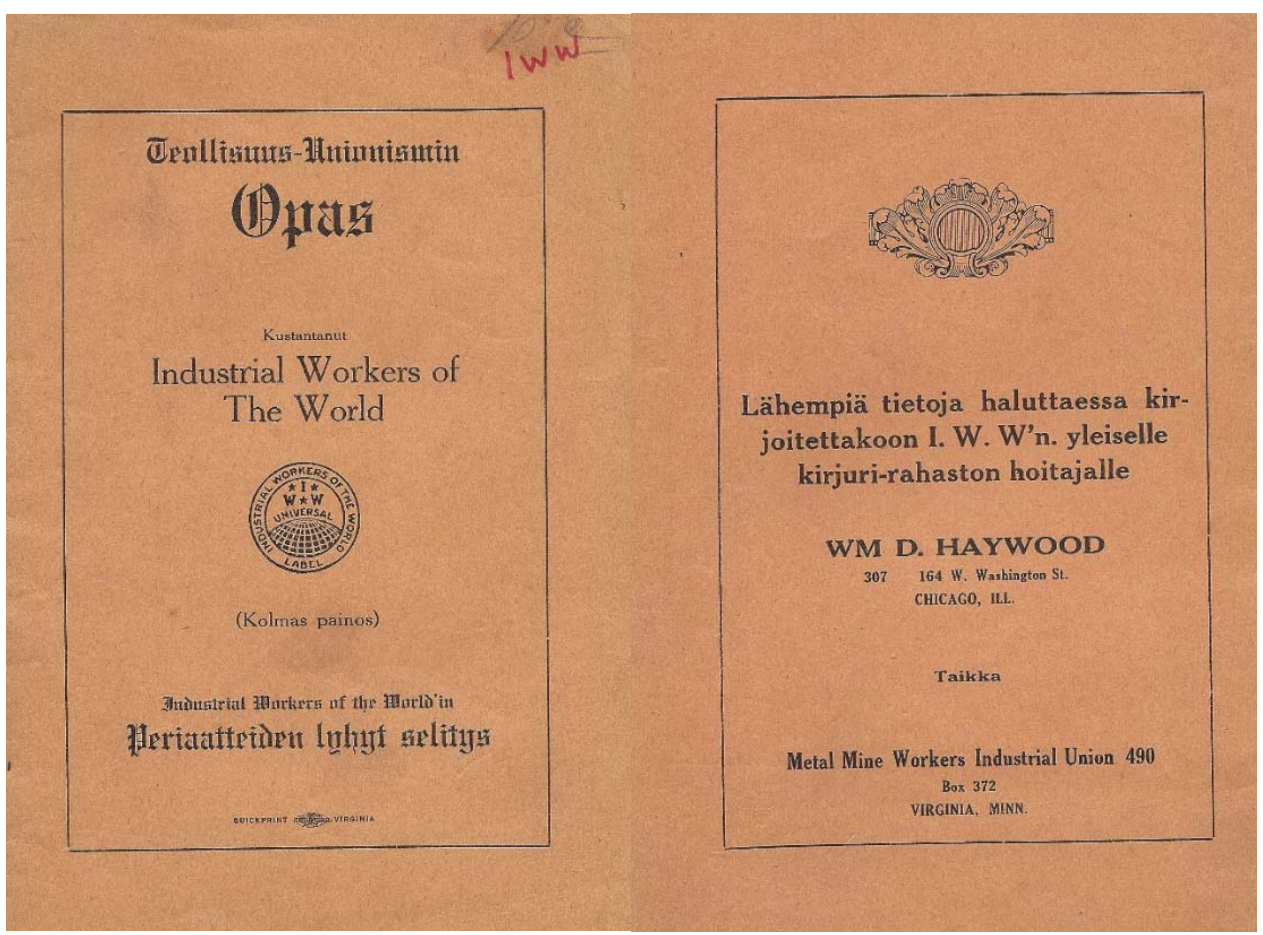

Figure 7.1-Images of the IWW produced Guide to Industrial Unionism, printed in the Finnish language to aid organizers in signing up workers during the 1916 Strike-author's collection.

The IWW's strongest mineworkers' local, part of the Metal Mine Workers Industrial Union 490, was also situated in Virginia. The IWW, and Haywood, noticed this significance and put money toward the printing of an industrial unionism guide, Teollisuus-Unionismin Opas (Guide to Industrial Unionism) in Finnish, to reach out to Virginia's Finnish immigrant population. For this reason, the booklet's author or authors took the time to mention that the booklet was "broadcast free to everyone who so requests." The guide, pictured above, was also an attempt to effectively communicate the IWW's primary message to would-be and nascent organizers as the strike's momentum progressed. This notion is forwarded because of the guide's lexis. As an artifact, the Guide to Industrial Unionism was a quickly developed and produced text that was meant 
to serve as a portable organizational tool. In format, the guide was likely produced to fit in a breast or side pocket. The booklet's paper is rather delicate, was likely inexpensive to reproduce, and was not designed to stand the test of time as a bookshelf text. The guide's audience was very general, as the text is a superficial manifesto of industrial unionism's main principles, which were not specific to the circumstances of the 1916 Strike. Further evidence for the quick production and dissemination of the guide is that it was printed by the "Quickprint" shop, a union printing shop located in Virginia.

A rhetorical analysis of the booklet demonstrates that it was an artifact designed to communicate logos and ethos appeals. Logos appeals in the text center on clearly and concisely transmitting the official dimensions of industrial unionism as espoused by the IWW. The booklet is a technical exploration of the IWW's guiding principles, written using jargon associated with its ideology. "Workers engaged in class struggle are the highest concern of society," the book claimed and therefore the IWW's, "constitutional convention, which drew up the by-laws according to the members, included the appropriate organization of industries that should act as a pillar of social organization. [According to the Guide] the world's workers, who are now struggling to form an industrial society, do so under the principles of the IWW." As a portable organizational tool, the guide was an introduction, an opening foray in the instruction of industrial unionism.

As the booklet was an introduction to the IWW and its ideology, it was perhaps not surprising that the final page of the booklet introduced the IWW's General Secretary, William D. Haywood, and invited readers to write to him for "more detailed information." To further familiarize readers with Haywood, the booklet included his 
signature. Haywood's reproduced signature in the booklet established a personal connection between him and the audience, and established him as the de facto leader of the 1916 Strike. The importance of having Haywood's ethos as the General Secretary of the IWW cannot be understated. Haywood's status as the head of the IWW had made him something of a celebrity, a famous, fiery figure in labor and union circles, though infamous on the national scene. Along with establishing Haywood's ethos as the point person for contacts with the IWW, the official seal of the IWW adorned the book's cover, giving the entire document an official-looking, working-class credibility. This seal, which included the IWW acronym situated over the globe's northern hemisphere, was prominently displayed in the center of the artifact. The official seal's design visually symbolized the international perspective of the IWW-the union was a representative of all the world's workers—it was a "universal" union. This universally implied prestige and power of the IWW meant that workers were part of something larger than themselves, larger than the Iron Ranges, and most importantly, larger than U.S. Steel. As a mobile organizational tool, the Guide to Industrial Unionism was likely distributed in the streets of Virginia and was perhaps handed out during parades and street speeches, which were common aspects of IWW organizational tactics. Strike parades and processions had an immediate effect on audiences that lined the streets of parade routes. When the 1916 Strike began, the streets of Mesabi Range municipalities were filled with strikers, and one of the most impressive displays of power and solidarity was the critical mass of a strike parade. Similar to the IWW's industrial unionism treatise, strike parades of IWW members were designed to visually assert the credibility of not only the IWW, but also the strike actions of workers. Fly-by-night organizations with 
limited resources, both financial and human, did not organize orderly parades of welldressed men, women, and children who were accompanied by boisterous brass bands. In orchestrating such public displays of coordinated working-class culture, the IWW was demonstrating that they had the organizational acumen to get people on their feet and marching to the same beat—literally.

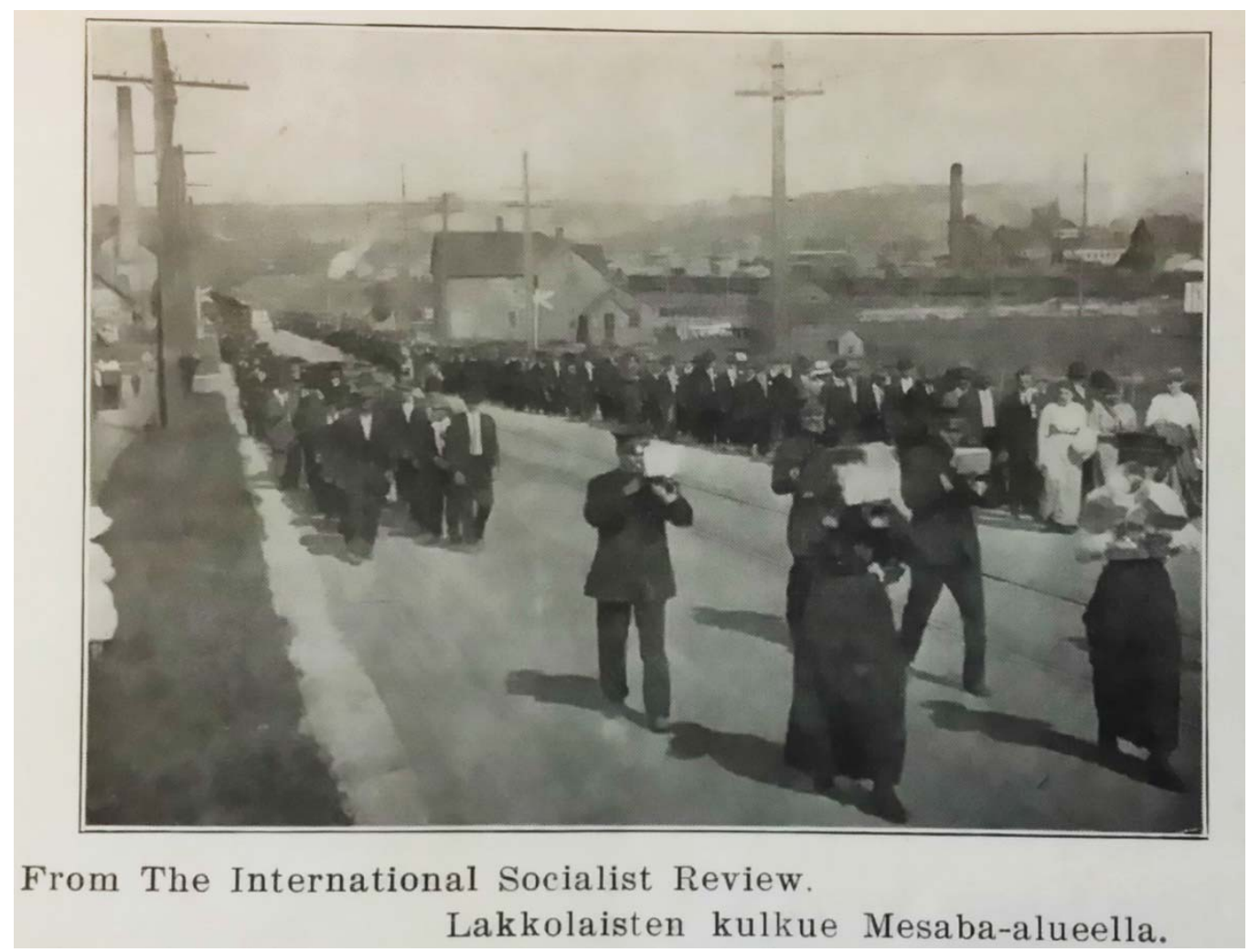

Figure 7.2-IWW parade through the streets of a Mesabi Range town--International Socialist Review

In addition to currying ethos, strike parades were also pathos appeals. As depicted in the image of a Mesabi Range strike parade above, these mobile public gatherings were festive occasions-jovial introductions to the IWW and striking workers. This type of public introduction in a celebratory manner was especially important for dismissing 
company warnings that the IWW was an organization prone to disarray and violence. Neatly organized rows of marching strikers, accompanied by a brass band, and led by the wives and children of striking workers indicated to audiences that the IWW was not a band of rag-tag, bomb throwing anarchists - as the mining companies had implied. Also important in strike parades was the style of delivery for the aforementioned arguments. The lexis of a strike parade was just as important as the ethos and pathos appeals that were conveyed. As the image above demonstrates, people in parades often dressed in "Sunday bests" or official uniforms (such as the band) to portray a sense of decorum and order. In this case, the IWW's argument was that it was a credible and genial union of engaged striking workers who expressed discontent in a stylish manner that was both formal and purposeful.

Strike parades were a local affair, confined to the social spaces occupied by strikers and the immediate audience. They were an effective method of communicating messages of solidarity, credibility, and joviality, but only to a limited audience in a defined landscape. Due to the sheer size of the Minnesota Iron Ranges, strikers were separated by miles of physical space. The IWW utilized a mobile message mechanism when it began printing the Strikers' News, a locally produced newspaper dedicated to portraying the events of the strike from a pro-union perspective. 


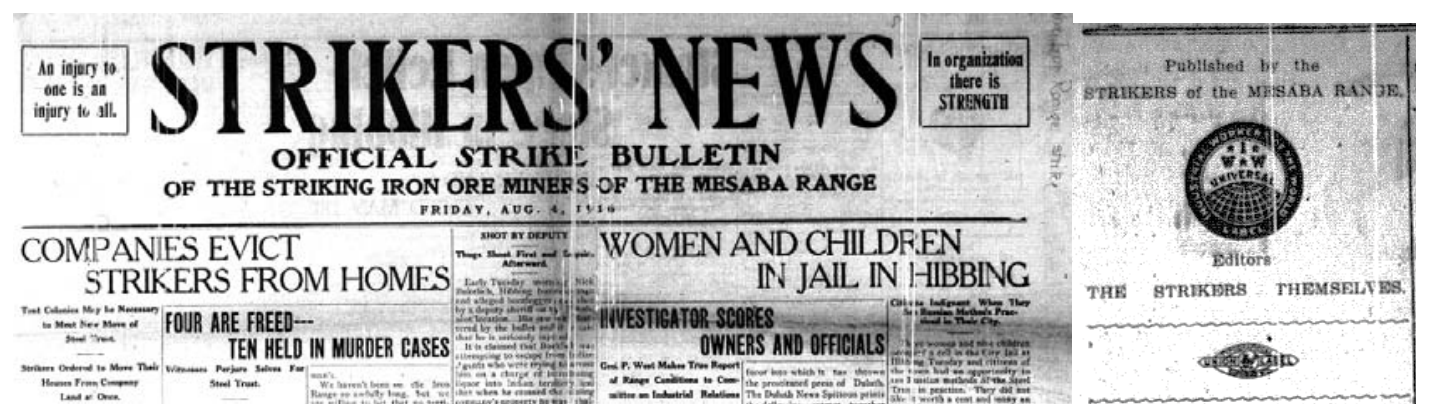

Figure 7.3-Strikers' News masthead and IWW logo--Minnesota Historical Society

For striking workers, the Strikers' News was an important and far-ranging mobile mouthpiece, a textual oration of IWW principles, strike activities, and mining company transgressions against the working-class. Rhetorically, the newspaper was steeped in passionate appeals that sought to engender interest, empathy, and compassion for striking workers. It was also a locally produced chronicle of strike events. Producing the newspaper locally was an ethos appeal that highlighted the decentralization of the IWW and the situation of control in the Ranges' rank-and-file. The argument made in producing the newspaper locally was that strikers were driving the efforts of this labor action and this increased the credibility of the IWW's assertions that the union was a rank-and-file based organization. Publishing the newspaper on the Iron Range was also an attempt to negate the "outside agitator" label that came as criticism from mining company managers and the kept press. The IWW made every effort to detail that the Strikers' News was "published by the STRIKERS of the MESABA RANGE," and even edited by “THE STRIKERS THEMSELVES.” The company line in past strikes, and especially in the 1913-14 Michigan Copper Strike, was that the union and all its material culture was the work of outside agitators coming into mining districts and stirring up 
contented workers. The IWW was attempting to make certain that the readers of the Strikers' News knew who had reins of the most important mobile mouthpiece of the strike.

A common feature in strike publications was the demands of the striking body of workers. Newspapers were one such place where annunciation of strike goals was presented to the public. The 1916 Strike was no different, and the demands of striking workers were published in the Strikers' News and in other media outlets as well. The original demand of the strikers was simple: the abolition of the detested contract mining system. As the national leaders of the IWW got more involved, the number of strikers increased, and the demands of the strikers were articulated in a more proficient manner. ${ }^{233}$ The updated demands of the strikers in mid-June were as follows:

1) A straight eight hour day for all men

2) A minimum wage of $\$ 2.75$ for surface labor and $\$ 3.00$ for underground labor with $\$ .50$ a day additional for wet places

3) The abolition of the contract system

4) A semi-monthly pay day

5) The men were to be paid when quitting or discharged

6) The abolition of the Saturday night shift with full pay

7) The return of all strikers

8) The abolition of the private mine police ${ }^{234}$

${ }^{233}$ State of Minnesota, Department of Labor and Industries, Fifteenth Biennial Report, 168-169.

234 Strikers' News, various issues. 
The most important point regarding the strikers' demands was that union recognition was not included. This was a tactic to checkmate United States corporations' unwillingness to meet and bargain with organized labor. In past strikes in the Lake Superior basin, such as the 1913-14 Michigan Copper Strike, one demand from strikers was recognition of the WFM as the elected representatives for workers. Knowing that this demand would be a barrier to labor negotiations, the IWW did not ask that strikers require union organization as a condition for the resumption of work.

In addition to the Strikers' News there were several immigrant presses running stories partial to Minnesota's striking workers. There were at least seven non-English, IWW sanctioned newspapers reporting on the strike: the Polish language Solidarnosc (Solidarity), located in Chicago; Il Proletario (The Proletarian), an Italian language newspaper located in Boston, Massachusetts; A Bermunkas (The Wage Worker), a Hungarian semi-monthly located in New York; the Swedish-Norwegian-Danish Allarm located in Minneapolis; the Darbininku Balsas (The Voice of the Worker) located in Baltimore; and lastly, Sosialisti, a Finnish language newspaper. Arguably, the most important was Sosialisti, a publication of Finnish immigrants situated in Duluth. Sosialisti was significant to the strike because of the important roles Finnish immigrants had played to nurture, agitate, and bring about the strike. The newspaper was also important because Sosialisti was located in Duluth, less than seventy miles away from the action. This gave the immigrant newspaper great credibility among the Lake Superior region's large Finnish immigrant population, many of whom also worked in the extractive industries in northern Wisconsin and Michigan's Upper Peninsula where the 
IWW might possibly forge sympathy strikes in the march toward a general strike in the Lake Superior industrial basin.

The 1916 Strike far surpassed all other previous attempts at organization of mineworkers on the Iron Ranges. IWW officials claimed that approximately 15,500 mineworkers were on strike and that over 7,000 of these idled workers had joined the Wobblies. The mining companies' estimations placed the number of strikers at a significantly lower tally, estimating that 7,000 to 8,000 men participated in the walkout. ${ }^{235}$ The actual number of men on strike was probably somewhere between these two figures. Enticing more workers to walk out of area mines was the primary function of the IWW's publications. These mass produced publications were a running correspondence between workers, the IWW, and potential future union members.

While the IWW was mass communicating, mining company executives were busy letter writing during the strike. Daily correspondences between subordinate mine managers on the scene and higher ups at corporation headquarters darted back and forth in the mail, and likely over telegraph and telephone lines. James D. Ireland, General Manager of the Virginia Ore Mining Company, a subsidiary of independent operator M.A. Hanna \& Co., reported back to his bosses almost daily. His reports generally began with an assessment of the day's activities at Hanna's properties, after which he included some additional information on major events in the general region. His assessments of the mines and their risk of being overrun by striking workers were a barometer of the strike's "temperature," and the daily advances of striking workers in shutting down mines were

235 State of Minnesota, Department of Labor and Industries, Fifteenth Biennial Report, 168. 242 
worrisome to the bottom lines of mining companies. From Ireland's correspondences, it seemed there was a looming specter over the Ranges and it was spreading like the German measles. In one correspondence he forebodingly wrote, "I suppose it will only be a question of time before the trouble spreads to [the Brunt Mine and Nashwauk in Itasca County]. They have not pulled off a strike at Eveleth until yesterday, but [the mining companies] are having their troubles there now the same as we are. Of course the strikers are bent on tying up the whole range."236

Just how strikers were able to shut down mines has been somewhat of a mystery, but correspondences from Ireland demonstrate the rather simple tactics employed for shutting down a mine: "about fifteen strikers came over to the Brunt mine yesterday and got in the approach [mine entry point]." Thus, the method for shutting down a mine was to occupy the entrance and then attempt to call out the mineworkers. Apparently the strategy worked well as underground mine after mine was shut down; however, the fifteen strikers at the open pit Brunt Mine were not so successful because "the deputies drove them out, and unless they come over in a very considerable force I do not think the Brunt men will pay any attention to them."237

Ethnicity, assimilation, and the nationalities that worked in underground mines versus pit mines also played a part in the successful striking of a mine. The laborintensive system of underground mining found more immigrant workers doing the dirty,

\footnotetext{
${ }^{236}$ James D. Ireland to M.A. Hanna Co., "Strike Situation Correspondence,” June 23, 1916, Butler Brothers and M.A. Hanna Company Records Collection, Iron Range Research Center, Chisholm, Minnesota, Box MSS 158, Folder NE, Lake Superior-General_Labor Lake Superior Situation 1916, 8370.

${ }^{237}$ James D. Ireland to Virginia Ore Mining Company, "Personal Correspondence," June 28, 1916, Butler Brothers and M.A. Hanna Company Records Collection, Iron Range Research Center, Chisholm, Minnesota, Box MSS 158, Folder NE, Lake Superior-General_Labor Lake Superior Situation 1916, 8370 .
} 
wet, and toilsome labor of subterranean extraction. Pit mines, somewhat less dangerous and labor-intensive, attracted more "American" and "Americanized" workers. Ireland made this distinction in his letter reporting on strike conditions, "at the Brunt [pit mine] we have men who started working for us as soon as they got out of school in 1906 and they have worked for us ever since and have absolutely no sympathy with this movement." Ireland noted that while these workers were born of "foreign" parents, they had, "Americanized, and while they of course can be intimidated they will not as a whole be intimidated as easily as most of the laborers, and very few of them would join the I.W.W." Ireland went on to provide further commentary regarding "American" workers, "then we have a large number of Americans at these properties who are absolutely loyal and intend to work while wages are good." ${ }^{238}$ While mine managers had their difficulties dealing with strikers on the ranges, the Duluth-Superior docks were targeted by the IWW as a way to pinch production and distribution on both ends of the hinterland-metropolis corridor.

Cronon's Metropolis-Hinterland Model suggests that the Duluth/Superior docks, which handled the shipping of the ore, would play an essential role in the strike as well. Mining companies knew this and were doing all they could to head off any sympathy or solidarity strikes by dockworkers in the Duluth/Superior environs. In an attempt to provoke a strike across the entire iron ore industry, the IWW targeted the docks of Duluth/Superior in an effort to shut down iron ore production and delivery. Oliver and the Independents closely monitored the situation and were deeply concerned that the ore

${ }^{238}$ Ibid. 
that they had stockpiled in the event of an emergency, such as the strike, would cripple profits. Ireland wrote of the impending dock strike, "the I.W.W. are beginning to agitate a strike on the docks, and the two Duluth [news]papers do all they can to fan the thing along by interviewing every red shirt they can find and making their headlines give a misleading impression." ${ }^{239}$ In another letter Ireland wrote regarding the Twin Ports' docks, "the rumor that I heard relative to Seamen's Union strike was secured from the head of the Thiel Detective Service, who told me a strike was contemplated, but did not think it would be very successful, as the [American] Federation of Labor were opposed to it and that it would not receive their backing." In addition to the docks, the rail arteries that connected the Twin Ports with the hinterland were concerning to mine management. Ireland pensively penned, "the strike agitators came to Two Harbors yesterday afternoon and attempted to start something, but were induced to leave town, and while there are a great many Socialists on the Iron Range, I think it is the feeling that employees on this [rail]road will not strike." 240

As mining managers worked to quell potential agitation on the docks and rails, both the Oliver and the Independents continued to suffer under the decreased industrial output. The sabotage-inspired withdrawal of efficiency, this massive labor strike, was working. Ireland summed the effects of the strike in a June 28, 1916, letter to Hanna headquarters in Cleveland, Ohio, "the result [of the strike] is that a great majority of the underground mines have shut down. Mr. Hunner [another manager for an Independent

\footnotetext{
239 Ibid.

240 James D. Ireland to M.A. Hanna \& Co., "Personal Correspondence," June 30, 1916, Butler Brothers and M.A. Hanna Company Records Collection, Iron Range Research Center, Chisholm, Minnesota, Box MSS 158, Folder NE, Lake Superior-General-Labor Lake Superior Situation 1916, 8370.
} 
Mine] told me that practically all his underground properties were shut down." Ireland mostly blamed the IWW and the strikers for the shutdown, but Hunner apparently blamed “his" workers' cowardice, as according to Ireland, "he advised his men he would keep their jobs open for them if they came back to work within a short time, but if they continue to be willing to be bull-dozed by the strikers that he would board up the Harold [Mine]. ${ }^{241}$

The situation was the same all over the Mesabi Range. Ireland noted, "I see in the papers that the Oliver Iron Mining Company is starting to board up some of its underground mines since not enough men will come to work to justify working the properties...it would be a good thing if the companies who can shut down [their mines] keep them shut down, because men are leaving the Mesaba [sic] in great quantities and going to Butte, the Copper Country, Arizona and the old Ranges." The situation in the Western Mesabi mines of Itasca County was much different and Ireland attributed it to Itasca County's law enforcement procedures, "the Sheriff of Itasca county will, I believe, prove to be a much more forcible man than sheriff Meining of St. Louis County, and he has a corking good deputy as his assistant at Nashwauk, and the instructions to the police and the sheriff's deputies in Nashwauk are to keep disorderly characters out of Nashwauk."242

As the strike wore on, it would become clear that violence was a key feature in the tense labor relations of the Minnesota Iron Ranges, and the 1916 strike was the largest

\footnotetext{
${ }^{241}$ Ireland to Virginia Ore Mining Company, "Personal Correspondence," June 28, 1916. Author added Italics for emphasis.

242 Ibid.
} 
and bloodiest ever in Minnesota. Both sides claimed atrocities. For the first time on the Iron Range, mineworkers met the physical force of the mining companies with physical force of their own. The IWW's methods of combating the mining companies' intimidation are clear from a 1916 article from the Duluth News-Tribune:

Fifteen hundred striking iron miners held a meeting tonight in the Finnish Socialist Hall under the leadership of IWW agitators. They threatened a three for one retribution when informed of a resolution adopted at a citizens meeting ordering the strikers out of the city (Virginia). "For every one of our members who is a victim of the gunmen who will doubtlessly be imported by the mining companies, three mine officials will pay the supreme penalty," declared W.D. Scarlett, IWW leader of Chicago who presided at the meeting. The meeting tonight came as a climax to the walkout of nearly 2,000 miners from the locations of Aurora, Biwabik, Eveleth and Gilbert. Yesterday the strikers started to march upon Virginia and the advance guard arrived late last night. There was no disorder, and no general strike was declared until tonight. It is the claim of the miners that none of the workings will operate today. W.D. Scarlett presided at the meeting; with him was Carlo Tresca, fellow worker Schmidt, and local leaders, among them Joseph Gruny [sic], one of the strikers arrested by Virginia authorities on charges of inciting a riot. ${ }^{243}$

${ }^{243}$ Duluth (Minnesota) News-Tribune, 6 June 1916 
Mining company managers blamed organized labor for the bloodshed at the onset of the 1916 strike, but an investigation of the 1916 strike by Martin Cole and Don Lescohier, which they submitted to Minnesota Governor Burnquist, stated differently: We are entirely satisfied that the mine guards have exceeded their legal rights and duties, and have invaded the citizenship rights of the strikers. Such violence as has occurred has been more chargeable to the mine guards and police than to the strikers, and the public police departments have entirely exceeded the needs of the situation and have perpetrated serious injustices upon the strikers. Every shooting affray that has occurred on the Range has occurred on public property. The parades of the miners have been peaceful; the public police have had no trouble in maintaining order, and if the private guards had been compelled to remain on company property we do not believe that there would ever have been any bloodshed on the Range. ${ }^{244}$

The Ranges' Progressive government officials were caught in the middle of the escalating turmoil. Victor L. Power, attorney at law and Hibbing's fighting Progressive mayor, could only speculate on the coming labor dispute. The day the strike began, June 9, 1916, at the seemingly far off St. James Mine in Aurora on the other side of the Mesabi Iron Range, Power simply wrote, "District Court Ira Smith v. Ray O. Maki-verdict for the plaintiff 425.00" and that "Mrs. Ernie Larch, Saturday Club called." Sometimes referring to himself in shorthand, Power or alternately V.L. Power or V.L.P. had little on his mind in June of 1916 other than fishing as a June 14 angling trip was recorded as,

${ }^{244}$ Duluth (Minnesota) Herald, August 16, 1916. 
"V.L. Power Fishing." Tuesday, June 20, 1916, however, turned Power's world upside down. On this day he recorded that, "Strike called by I.W.W. at Workers Hall [in Hibbing]." The next day, his diary recorded, "W.J. West (O.I.M.C) called" and then "I.W.W. parade stopped by Wm. King [Hibbing police]. Leaders interview V.L.P." In the coming days Power's diary entries were increasingly related to strike events: Thursday, June 22, read, "I.W.W. parade, 900 strong, 10.30 am." On Wednesday, June 28, Power was in his office and wrote, "I.W.W. delegation called." 245

A friend to organized labor, but no friend to the revolutionary IWW, Power's political life seemingly hung in the balance during the strike. Behind closed doors he was meeting with Wobbly delegations, but he was also holding court with representatives of the mining companies. His general impulse was to support Hibbing's workers, though he simultaneously publicly rebuked the IWW and was all the while critical of mining companies in the early days of the strike. In public, Power's rhetoric was simple and straight to the point regarding the IWW, as one newspaper article heralded, "II am not behind the I.W.W. as an organization,' stated the mayor. 'It is not organized labor. If the working men however, decide that they want their conditions bettered that is their privilege, providing they go about their business to do it within the laws of the land. We will not allow any threats to be made within the jurisdiction of the Hibbing police authorities and we will offer protection to workingmen that desire to go to work."'246

\footnotetext{
${ }^{245}$ Victor L. Power, "Standard Diary, 1916" Vol. 2, Victor L. Power Papers, Minnesota Historical Society, St. Paul, Minnesota, Box 1.

${ }^{246}$ Ibid.
} 
Along with Hibbing's other government officials, Power sought to play catch-up with the strike and the local government's united response to the labor conflict. Newspaper clippings in his journal recount the efforts to deliver a strong message to the IWW's leadership: "Special council meeting called 8 pm," where it was determined that the "VILLAGE COUNCIL WILL PROTECT THE LABORER TO WORK...[the council] assured protection to all working men of mining companies coming to and going from work if within the jurisdiction of the village authority." Additionally, Power sought to extend Hibbing's decision-making to other areas of the Range, "the Council instructed Recorder D.D. Haley to write members of every village council on the range asking that they send representatives to a central meeting to be held in Hibbing at eight o'clock Monday evening to discuss a means of bringing about a reconciliation between the mining companies and the striking miners." While this was the Hibbing city council's public response to the IWW, and the growing labor conflict, Power surreptitiously recorded in his diary that, "the council members discussed informally at the close of the meeting behind closed doors the question of picketing, the rights of striking miners to do so, and how far they can exercise their power." As a Progressive politician, Power was caught in the middle of two powerful ideological forces: the Progressives' compulsion to thwart the power of trusts and large corporations and a strictly reform-minded political impulse that excluded revolutionary organizations such as the IWW. Power was reticent to take sides and his rhetoric in the early weeks of the strike underscores his attempt to appear as an arbiter of industrial conflict, one who was applying himself diligently to the 
preservation of civility on Hibbing's streets. But, as a June 29 entry in his diary indicated, even that was going to be difficult: "Strike 'scuffle' on $3^{\text {rd }}$ Ave near Sellers Pit." 247

By mid to late June, the Iron Ranges were in the midst of an epic battle between labor and capital. The sides had been established and the orange-red hills, open pits, and streets of the Iron Ranges were about to witness the greatest labor war in Minnesota's history. The Oliver, due to its substantial resources, would lead the way but the Independents were arming as well. Over time, the Ranges began to look similar to theaters of trench warfare in Europe as, "trench operations of warfare have been instituted in the defense work at the mines. At the Ordean, which is an open pit and where the entrance is by the way of a huge stockpile of ore, a trench or ditch has been dug through the stockpile with a steam shovel, so that it cannot be crossed by the strikers in attempting to enter the open pit." If this was not war-like enough, the Oliver was armed to the teeth and itching to open fire, "Oliver police are guarding the properties in all sections. They are armed with Winchesters and any striker who steps on mining company property does so at the risk of his life, according to warnings issued by the mining companies." ${ }^{248}$ It was open class war on the Minnesota Ranges and lead, passion, and fiery rhetoric flew fiercely in all directions.

\section{Fiery Rhetoric and the IWW's Cultural Apparatus}

At first glance, the purpose of the IWW's multi-media offerings may have appeared to be solely antagonistic, but that would be a simplistic rendering of a dynamic and vibrant usage of rhetoric to communicate effectively with the Wobbly's intended

\footnotetext{
${ }^{247}$ Ibid.

${ }^{248}$ Duluth (Minnesota) Herald, July 1, 1916.
} 
audience, immigrant mineworkers, during the early days of this industrial conflict. There was certainly a very sharp edge to the IWW's media, but the purposes for careful creation, distribution, and production of the IWW's organizational materials was multifaceted. The goals of the IWW's early strike rhetoric were: 1) provide, at the very least, a rudimentary understanding of revolutionary industrial unionism. The IWW was aware that the ideological tenants of industrial unionism were complex, but the union made attempts to distill the technical language of ideology into concise texts and visual interpretations of key concepts; 2) inform and instruct on tactics used in the class struggle. For the IWW, the 1916 Strike was a battle in the class war. The IWW was interested in training organizers and agitators for the inevitable commencement of a general strike that would cripple United States industry and provide workers with the economic upheaval that would occasion a revolutionary change in society. The IWW had a long game in mind and transmitting the tactics for bringing about a revolutionary experience were of paramount concern; and, 3) to bring the Ranges' multi-ethnic audience together. Mining companies attempted to divide the Ranges' working-class by importing immigrant scabs and strikebreakers, favoring certain ethnicities, and sometimes segregating ethnicities in camps and company spaces. The IWW wanted to bring these disparate voices (and languages) together in the One Big Union.

The most difficult bridges to cross for the IWW's rhetors were the cultural, linguistic, and socially divergent pulls of the Iron Ranges' multi-ethnic populations, some of which were suspicious of the IWW. "Austrian" workers on the Minnesota Iron Ranges were perhaps most suspicious of the IWW and their organizers. As strikebreakers during the 1907 Strike, scabs from Slavic counties in Europe ran into direct confrontation with 
Finnish and Italian workers. During the 1916 Strike, some of these same Finnish and Italian strike activists were intimately involved in the administration and implementation of the strike's activities and goals.

Ethnic rivalry and distrust of the IWW was a potential problem and one that concerned the IWW's organizers before and during the strike. Due to this concern, and after learning from previous strike actions that were fragmented by ethnic discord, the IWW called on its ample experience with organizing immigrant workers and brought in a talented cadre of organizers, while also recruiting local organizers, who could speak all the languages of the Ranges' working-class populations. This tactic worked. An oral history interview with Slovenian American Veda Ponikvard, a child during the strike, indicated that "for the most part [Slovenian immigrants] were a little bit confused [regarding the IWW prior to the strike]. There were a few people that were in business, and some who were very active in the SNPJ [Slovenian immigrant socialist organization], who were exposed [to unionism]. They would go to conventions in larger cities and so forth and mingle with people who were working in factories." In these interactions Slovenian immigrants came into contact with the goals and methods of industrial unionism, but as Veda suggested, "they [became] a little bit more knowledgeable about the whole thing. But your total population at that time was wondering about the whole thing." Over time, the knowledge of unionism and distrust of the IWW dissipated, and the Ranges' Slovenian population became, according to Veda, "very sympathetic" to the strike. $^{249}$

${ }^{249}$ Veda Ponikvard, "Oral History Interview," May 13, 1988. 
An important tool for organizing such multi-language groups was the use of radical cartooning and the IWW was very effective in this means of communication. As mentioned in Chapter 5, cartoons provided the IWW with the ability to translate very complex and didactic messages via an image. Important Wobbly concepts such as industrial unionism, sabotage, and solidarity were interpreted in these images. Perhaps the most important aspect of using images for the IWW during the 1916 Strike was that the audience receiving the message did not have to be able to communicate in the same language. Because many immigrants had previous experience with work be it agricultural or industrial, familiarity with ethnic repression in their home countries, and an understanding of what it meant to be subservient to the kings and queens of Europe, the IWW was able to translate complex ideological messages via images of exploitation of workers, the perils of dangerous working conditions, the suppression of free speech violations, and a decidedly underdog status to immigrant mineworkers on the Ranges.

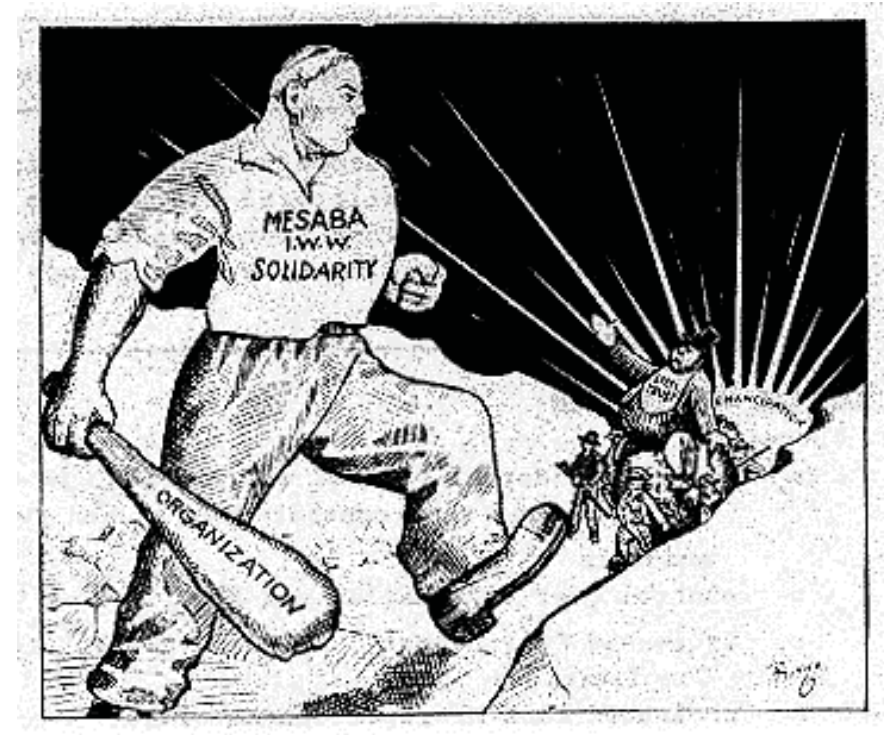

Figure 7.4-IWW cartoon produced during the 1916 Strike depicting the power of solidarity in facing the "Steel Trust"--International Socialist Review 
One of the most famous images from the 1916 Strike was the "IWW's Big Stick." This image encapsulated the gist of all the IWW's organizational rhetoric during the strike. The large IWW figure represented the union's collective rank-and-file, which, when acting in solidarity with one another, grew strong. The huge club in the hand of the "Mesaba I.W.W. Solidarity" figure symbolized what effective union organization could do for strike efforts on the Ranges. Perhaps invoking echoes of Teddy Roosevelt's "Walk Softly and Carry a Big Stick" foreign policy, the IWW figure was poised to make his way toward the rising sun, which was labeled "Emancipation." Standing in the path of the Mesabi workers were diminutive iron range bosses, led by the primary character who was labeled as the "Steel Trust." Rhetorically, the cartoon made a strong emotional appeal to its audience because the IWW character is so impressive, steadfast, and strong when confronting the minute Steel Trust figure. The cartoon also used a sense of juxtaposition to argue that if workers of the Range would stand together as one, they would be able to turn the tables on the mining companies and gain power over the conditions of their labor.

In analyzing the image's lexis, the artistic, stylized working-class connotations are apparent. Predating socialist realism as an artistic genre, the image harkens none the less to a personification and glorification of a once meek proletarian actor against former oppressors - the actor's material ties to the working-class (boots, pants, plain shirt) and the dawn of a proletarian emancipation. Even the image's landscape indicates a stylized mineworker's environment. The cartoon's artist took pains to interpret the rising of the Ranges' masses in an attempt to draw-in and educate the audience in regards to the power of solidarity as a means to counteract the power of mining companies. 
But as Jack Selzer indicated in his article, rhetorical analyses should not be limited to texts or visual arguments. He also cites architecture as a rhetorically derived medium and the IWW's use of landscapes of discontent during the 1916 Strike was ubiquitous. The Finnish socialist halls of Virginia, Hibbing, and smaller cities across the Iron Range provided a staging area for agitation and organization. The IWW and Finnish immigrants learned an important lesson from the 1907 Mesabi Strike and carried it over into the 1916 strike. Working with the WFM in the 1907 and 1913-14 Strikes made Finnish immigrants understand their importance to American working-class struggles and they began to understand the significance of their accrued material culture to labor actions in the United States. According to historian Dr. Auvo Kostiainen, Finnish immigrants, "came into close contact with American labor organizations, and they stuck together with other nationalities on the Mesabi Range." ${ }^{250}$ The lessons of collective labor organization became firmly entrenched in the consciousness of Finnish immigrants and they were receptive to opening their social spaces of discontent to other ethnicities. ${ }^{251}$ Thus, Finnish immigrants hastened the unification of labor during the 1916 Strike by providing the IWW with an intact grassroots organizational structure replete with social spaces that were functional command centers. ${ }^{252}$

\footnotetext{
${ }^{250}$ Kostianen, The Forging of Finnish-American Communism, 37.

${ }^{251}$ Ibid., 37.

${ }^{252}$ Ibid., 36-37.
} 


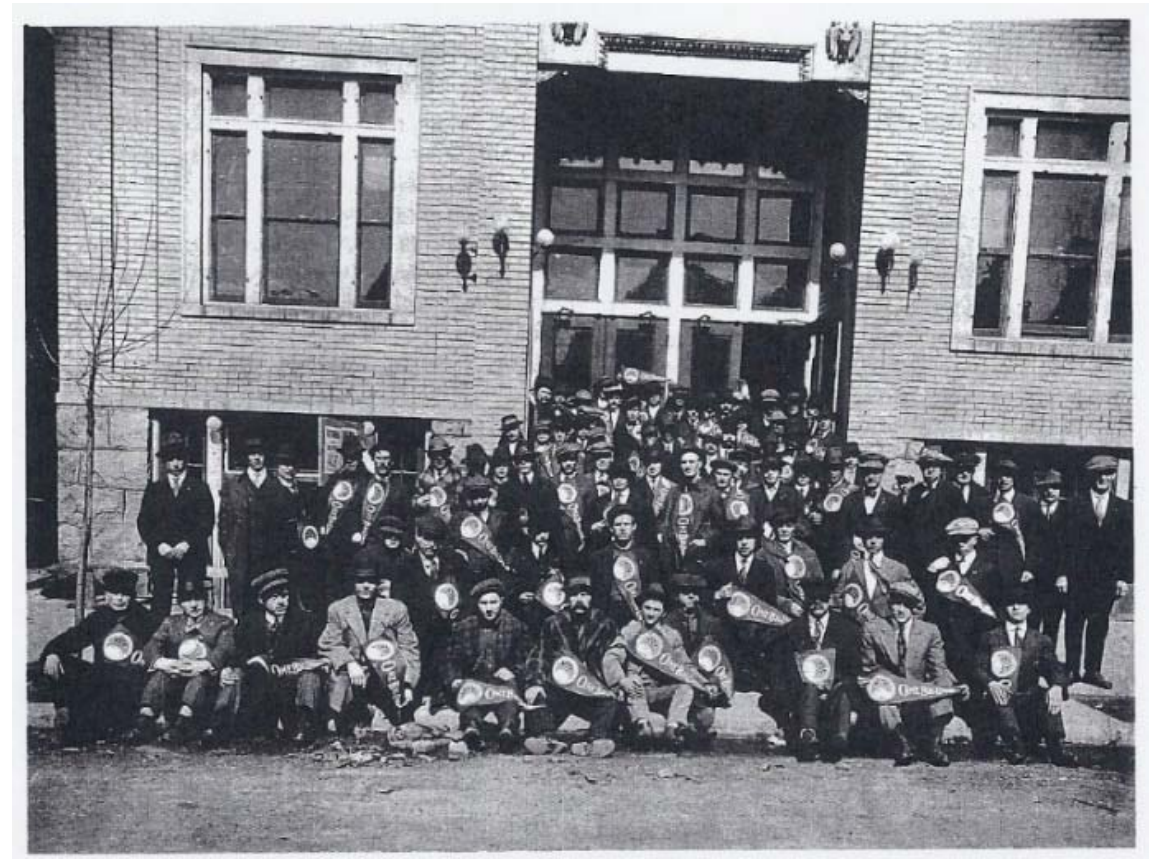

Figure 7.5-IWW members outside the Virginia Socialist Opera House--Iron Range Research Center

As a space of discontent, the Socialist Opera House in Virginia made a strong argument for the power of material culture to act as communicative expression. In the image above, which features a group of IWW members standing in front of the Opera House's façade, the staging of the image and the adornments of both the building and the people demonstrate the lexis involved in the composition of the image. As Roe commented in his piece regarding Virginia's Socialist Opera House, the hall was a heavily stylized expression of working-class culture. In the above image, the audience was able to view some of the refinements on the Opera House's façade. The same is true with the union members posing for the image as they were dressed in Sunday bests, accented by hats, suits, and ties. The staging of the photograph was done with a keen 
sense of place and person in mind, as the IWW sought to portray its members as men of culture posing in front of a cultured, working-class venue.

Rhetorically, the image elicited feelings of permanence and solidarity, which were emotional appeals aimed at an audience who were hoping for some type of community experience. The sturdy brick walls of the Opera House served as the backdrop to the solidarity displayed by Fellow Workers who were proudly holding "One Big Union" pennants. These triangular cultural symbols that displayed the IWW logo and the words “One Big Union” expressed a sense of belonging, similarity of purpose, and a shared experience. This impression likely had a positive impact on the Wobbly's primary audience, immigrant workers looking to establish roots and make connections with new people in an unfamiliar land. A logos appeal was in the image as well. The Wobblies often made the argument that workers should be organized into One Big Union of all workers, which was a counterargument to the AFL's division of workers into craft and trades unions. In this manner, the image and the photographer were perhaps intending to make an appeal to the logical nature of workers' understanding of industrial unionism by highlighting the significance and unity of One Big Union ideology. Lastly, the image provided an ethical appeal as well as the building itself provided the IWW credibility as an organization and established a sense of permanence to the IWW's organizational efforts on the Ranges. By staging a photo in front of a grand, solid brick structure with many well-dressed people holding what were likely red One Big Union pennants, the IWW was expressing their integrity, durability, and stability as an organization.

As discussed in an earlier chapter, labor halls were the site of one of the IWW's most sacred rituals: singing. One of the most solidarity-inspiring expressions of Wobbly 258 
culture was the song, and as the IWW was known as the singing union, the Wobblies were masterful vocal rhetors. Wobbly culture provided many intersections for author, audience, and text in this regard. The union published songbooks and had a very talented group of songwriters who were able to express complex ideological material in a lyrical format. Ralph Chaplin, T-Bone Slim (aka Matt Huhta, a Finnish immigrant), and Joe Hill were integral and celebrated parts of the Wobbly's working-class culture.
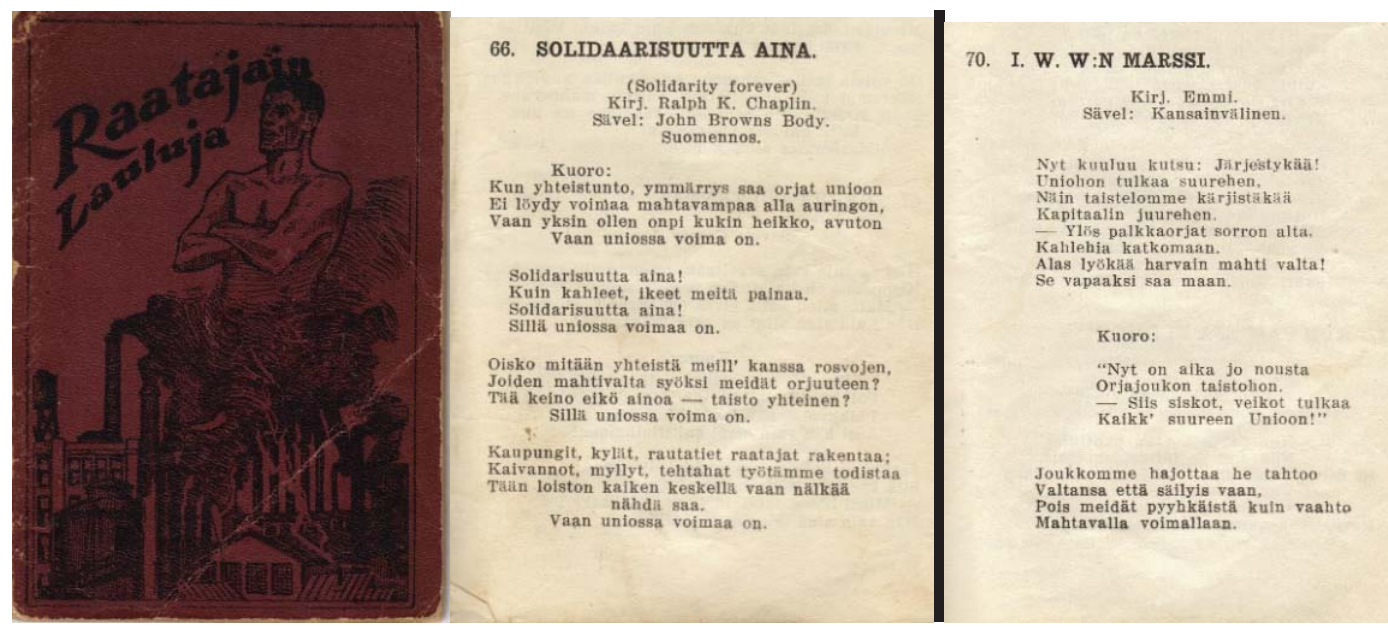

Figure 7.6-Finnish language IWW songbook that demonstrates the intersections between the American Wobblies and Finnish immigrants--author's collection

The above songbook titled, Raatajain Lauluja (Toilers' Songs), and lyrics pages were printed at the Finnish immigrant-owned Workers Socialist Publishing Company. Similar to the Guide to Industrial Unionism, songbooks were meant to be portable organizational tools and appeared in any place the Wobblies were attempting to organize (or agitate). Most often songs were sung at IWW meetings and typically ended a gathering of union members. In this way singing acted as a pathos appeal to the IWW's working-class membership. The Wobblies were a revolutionary industrial union and that was very serious business. Songs, however, provided members the opportunity to share 
moments of solidarity that were instructive but also entertaining and seemingly not as didactic.

One example of this lyrical, entertaining ideological transmission was song Number 70, "I.W.W.n Marssi," or "March of the I.W.W.s," written by "Emmi”" and sung to the tune of "Kansanvalinen." As a cultural artifact and artistic representation of the IWW as a singing immigrant based union, the song is unequalled in its analytic value. The song conclusively demonstrated the strong ties between the IWW and Finnish immigrants and mirrored the support Finnish immigrants gave to the IWW during the 1916 Strike. The song also offers a potential glimpse into the associational lives of Finnish immigrant rank-and-filers. The song's author, "Emmi," was likely enrolled at the Work Peoples College in Duluth as a student. And, while "Emmi" was perhaps enrolled in the College, he or she was probably not an official IWW organizer or a paid staff member of the Work Peoples College. The song itself provides evidence for this assertion. There is a lyrical innocence to the verses that seems to shun commonly used didactic terms indicating that the song might have been written by someone in the IWW's rank-and-file. Ties between College authors and the publishing company (also located in Duluth) were common and often student poetry, prose, and lyrics found their way into the Publishing Company's periodicals. It was also a common practice for College studentauthors to sign their work using a pseudonym due to fears of arrest and deportation"Emmi" is likely such a fictitious nom de plume.

When examining the song's text, the chorus is especially significant because it is a quote that is possibly taken from an IWW pamphlet or other official Wobbly media source. "Emmi" and the publishers of the songbook took the time to declare, using 
quotation marks at the beginning and end of the chorus, that the chorus had another author alerting the song's intended audience that there were others who had spoken these important phrases. Thus, the chorus becomes a statement of solidarity with the "One Big Union" within the song's general overtures toward collective action.

Equally significant are the song's temporal circumstances. The songbook is undated, but because it included the IWW's most popular song, "Solidarity Forever," which was written in 1915 and included in the IWW's Little Red Songbook in 1916, it is possible that "I.W.W.n Marssi" was written expressly for the 1916 Strike. Further evidence for this notion is that "Emmi" titled the song as a "March," perhaps intending the song to be an accompanying tune sung during strike parades through the streets of Iron Range towns. As is clear when the song is translated from the original Finnish to English, the song was a personal distillation of the IWW's ideology—a call to organization under the IWW and a statement of the power of collective action, which contained standard emotional appeals to themes of worker oppression, exploitation, and eventual rising of the working masses through union organization. The combination of logos and pathos appeals were a powerful organizing tool that "Emmi" utilized in her lyrics:

Now hear the call: organize!

The union is becoming greater [in numbers],

Our struggle agitates

The roots of capital.

--Get up wage slaves from your oppression.

Cut the chains that bind. 
Strike down the might of Oligarchs!

This provides your freedom.

\section{Chorus:}

"Now is the time to raise up

Struggling slave populations.

So sisters, brothers come all

To the One Big Union!"

Our masses dissolve their will

They once had the power but,

We have wiped away that scum

With a mighty strength. ${ }^{253}$

In the performance of the song, IWW members were often instructed to belt out the tune- to caterwaul—so that the song became a gravelly throated expression of workingclass irreverence and perseverance. Songs, and the act of singing, were an entertaining and lyrical, yet serious, way to transmit the power of collective action.

This particular cultural artifact, the songbook, also displays a unique lexis. The front and back covers of the songbook were made of a very tough fibrous material, indicating that the Workers' Socialist Publishing Company intended the songbook to be accessed and used in many different types of landscapes, settings, and situations. In addition to the songbook being a pocket-sized collection of lyrical ideology, the expense and care taken to ensure the durability of the songbook likely indicated that users

253 "Emmi," "IWW:n Marssi," in Raatajain Lauluja, Duluth, Minn.: Workers Socialist Publishing Company, n.d., song number 70 . 
intended to keep the book over a long period of time and use the book in interactive social settings where movement was not restricted.

Much like songs, the IWW employed poetry to frame the strike and its events in an innovative way. Similar to the previous examples of the Wobblies' socialist realist art forms and the tune "I.W.W.n Marssi," working-class poetry was designed to elicit an emotional response. One such poem, simply titled, "The Strike," was featured in Strikers' News:

Say what ye will, you howls of night,

The Strike upholds the causes of right:

The Strike compels the king to pause,

The statesmen to rebuild the laws.

Say what ye will, yell without truth;

The strike tears off the mask of things,

To mass and class the issue brings.

Say what ye will, the strike is good,

It clears things long misunderstood;

It jolts the social mind awake;

It forces men a stand to take.

Say what ye will, all else above,

The strike is a war for bread and love;

For raiment, shelter, freedom, all 
The human race can justice call. ${ }^{254}$

This poem's author, who did not identify herself or himself in the Strikers' News, was making an emotional appeal through the arrangement of a standard rhyming pattern and the evocation of common socialist themes of class-consciousness, morality, and sacrifice. The author was also likely attempting to inform and instruct regarding the difficult sacrifice of engaging in a labor strike, but intending to inform the audience that while difficult, the end results of such struggles were beneficial to all humanity. Shared sacrifice, then, becomes a major theme of the poem and its inclusion in the Strikers' News was likely an attempt to boost the morale of striking workers through a type of literary experience with a decidedly working-class perspective.

Given the aforementioned rhetorical appeals and offerings, the IWW had organized a potent multi-modal media campaign to unite workers and attack the Ranges' mining companies. The commencement and ongoing events of the strike were evidence that the IWW, their cartoonists, writers, and songwriters had developed and were implementing a dynamic cultural apparatus that challenged the power of corporate giants like U.S. Steel. The IWW was not winning the strike per se, but they were making headway into a stiff wind. The opening weeks of the strike were proving to be a decisive time and in this period mining company managers were beginning to understand that the IWW was making well-trod inroads all along the Mesabi Iron Range. The fear was that the strike would soon spread to the Vermilion and Cuyuna Ranges. Decisive action on the part of managers and mine owners was needed if they were going to halt, turn back, and

${ }^{254}$ Strikers' News, n.d. 
dislocate the Wobblies from the Ranges. In attempting to implement such decisive action mining company managers relied on repressive and steadfast anti-union strategies to attempt to break the strike. Company goons, local law enforcement members, middleclass business owners, and judicial maneuvering were all aspects of the plan to rid the IWW from the Minnesota Iron Ranges. These tactics were not successful in crushing the IWW or its rank-and-file and in a last ditch effort to break the strike, mining company managers enlisted the help of Minnesota's highest authority to do their dirty work. 


\section{Chapter 8: Minnesota's Governor Fires Back}

\section{Chapter Introduction: Critical History and the 1916 Strike}

This chapter is straightforward critical labor history of the part that Minnesota's

Governor played during the 1916 Strike. It is an attempt to impart and reassert voice to strikers who were silenced in their outrage over the partisan stance of Minnesota's highest elected official during the labor conflict. Numerous IWW sources made the accusation that Governor James A.A. Burnquist was acting in concert with mining companies to break the strike. These claims were dismissed at the time, but newly discovered primary documents suggest that these assertions were accurate. This chapter chronicles the collusion between Burnquist and mining company management to deport IWW organizers in an attempt to end the strike, while at the same time disciplining labor in Minnesota. Methodologically, the chapter reveals that labor history research should not be confined to labor sources in the attempt to give workers a voice. At times the harshest indictment of unethical historical actors comes from their very own words. Such is the case with the tragic, violent trampling of strikers' human rights in the 1916 Strike.

\section{The Plot to Rid the Range of the IWW}

For mining company managers, the plan to quell the 1916 Strike was simple: quash worker upheaval by any means necessary. In increasing increments of legal pressure, political scheming, and violence, Oliver and the Independents were relying on steadfast strategies and tactics to run the IWW off the Ranges. Mining company managers had many options toward this end including law enforcement officers, the courts, a private and well-armed army, and citizens' vigilante groups. The official line from management in private and in public was that the IWW and strikers were violence- 
prone revolutionaries. There was little support for this accusation as James D. Ireland, General Manager of the Virginia Ore Company, a subsidiary of Cleveland based M.A. Hanna \& Co., himself wrote on June 23, 1916, "there was no violence or trouble reported [from the IWW], and were it not for the miners being intimidated, practically all of our crew would be out to work." ${ }^{255}$ Thus, mining company managers were portraying the shouts, jeers, and picket lines of striking workers as the motive for a concerted, violent reply to organized labor. An unbeknownst additional resource in this fight against the "violent" IWW was the highest elected official in Minnesota-Governor Joseph A. A. Burnquist. There was, however, a set of standard operating procedures and mining company managers did not appeal to Burquist until they had exhausted all other options in attempting to break the strike.

As the strike reached late June, it became clear that one of the adversaries in this industrial war on the Minnesota Iron Ranges was especially keen to use all methods necessary to accomplish its goals. Mining companies' managers were prone to resort to violence in interactions with striking workers. Violence was a proven tactic to defeat organized labor. Most efficient at intimidation and violence were company police forces. Some corporations, such as the Oliver, had a standing police force made of heavies and toughs oftentimes recruited from large metropolitan centers. M.A. Hanna \& Co., an independent mining company, had to organize a police force specifically for this strike and looked to follow the model put forth by the Oliver. The first step in such a model of

\footnotetext{
${ }^{255}$ James D. Ireland to M.A. Hanna \& Co., "Strike Situation Correspondence," June 23, 1916, Butler Brothers and M.A. Hanna Company Records Collection, Iron Range Research Center, Chisholm, Minnesota, Box MSS 158, Folder NE, Lake Superior-General—Labor Lake Superior Situation 1916,
} 8370. 
suppressive violence was finding a first rate thug who had demonstrated past success in dealing with organized labor.

Hanna \& Co. called upon the services of Jack Rowett, former sheriff of Gogebic County in Michigan's Upper Peninsula. While mineworkers on the Ranges were barely scraping by, evidenced by their striking for higher wages, Hanna \& Co. was prepared to pay Rowett \$200.00 a month for his services. Ireland wrote in glowing terms of Rowett's prowess in using physical force and of his having "shot a man or two":

I heard that Mr. Munger of P\&M [Pickands and Mather] was making up his mind to get [Rowett] and I wanted to beat Mr. Munger to it as Rowett is a peach and the best man I know of with possible exception of Mr. Dave Foley, the Chief of the Oliver Police.

As you put it up to me to keep the mines working this summer and to be sure of being able to handle situations right and with force, I have to have a man with guts and experience... Rowett is a quiet spoken man but a champion wrestler and fighter and has a great record for nerve and while sheriff of Gogebic made a reputation for himself by not playing politics and by delivering the goods when called on. ${ }^{256}$

Ireland's letter went on to detail how Rowett would act in concert with local authorities to suppress union organization and what lengths and methods were approved of by the mining companies: "he will get in with the local authorities in each district and

\footnotetext{
${ }^{256}$ James D. Ireland to Howard Hanna, Jr., "Personal Correspondence," June 15, 1916, Butler Brothers and M.A. Hanna Company Records Collection, Iron Range Research Center, Chisholm, Minnesota, Box MSS 158, Folder NE, Lake Superior—General—Labor Lake Superior Situation 1916, 8370.
} 
in such places as we have a watchman [labor spy]. The watchman will be a man of his choice so he can depend on him." Like a union busting superhero, Ireland outlined the process for summoning Rowett and the source of his special union busting powers: "if trouble is brewing at any point the [Mine's] Superintendent will telegraph or phone Rowett and he will be on the job at once and work with the Superintendent and I will have him appointed deputy sheriff and we will of course have to stand back of him if he gets in trouble handling strikers." Closing out the letter, Ireland boasts that "Rowett is not a gun man but an awful handy man with his fists and putting hand cuffs on, tho I think he has shot a man or two, and I think I have a treasure of a man that I can absolutely bank on if we come to bat with the I.W.W."257

Having found a man capable of using force and violence to deal with striking workers, M.A. Hanna \& Co., like many of the other mining companies, turned to looking for a way to rid the Ranges of the IWW's organizers. Ireland noted that violence was one way writing, "Everyone is agreed that the best thing is to beat up the leaders and the Oliver Police do so whenever they get a chance and our man and the men he will get will do likewise as we have talked that over." 258

The situation was becoming deadly serious on the Ranges and especially on the Mesabi Range. Mining companies were losing money daily as most of the underground mines were shut down and the cessation of work in the pit mines was squarely in the IWW's sights. The companies, as demonstrated by Ireland's letters, were ready to employ violence at a moment's notice to break the strike, but their efforts so far had met

\footnotetext{
${ }^{257}$ Ibid.

${ }^{258}$ Ibid.
} 
with a staunch and increasing solidarity from the IWW's leadership and the rank-and-file. The companies in general, and Ireland specifically, were extremely upset that St. Louis County Sheriff John Meining would not employ such violent tactics as well. Ireland wrote caustically to Howard M. Hanna, Jr. in a personal correspondence: "The Sheriff of St. Louis County is not worth a D---. He is playing politics and looking for votes, and follows Dave Foley and the Oliver Police about and won't allow [Foley] to muss up the [IWW's] leaders, tho Foley has mussed up a few of them." Ireland was equally upset about the media coverage of the strike. In the past, mining companies had staunch allies in the kept press that publicly justified violence against strikers, but Ireland seemed to think that one newspaper in particular was neglecting its allegiances to mining companies writing, "the News Tribune of Duluth that you [subscribe to] is a dirty slut and always takes the side of the strikers." 259

The violence of company hired goons was not working, the St. Louis County Sheriff would not do their bidding, and the newspapers were not printing the right lieswhat were the mining companies to do? Well, they attempted to incite a violent vigilante committee to deport the IWW's leaders from the Iron Ranges. In the same letter to Hanna, Jr., Ireland wrote that "the towns people on the range will, I think, be with the mining companies in this if we can make them believe the mining companies," and he then wrote hopefully that "in fact at a mass meeting in Virginia last night they voted to deport all strikers because they said the strike affected business." 260

\footnotetext{
${ }^{259}$ Ibid.

${ }^{260}$ Ibid.
} 
A day later in a professional communication to Hanna's headquarters in Cleveland, Ohio, Ireland expanded on his information regarding the mass deportation, "yesterday afternoon there was a meeting of the citizens and businessmen to take steps against the strike agitators, and they appointed a committee and called for a mass meeting last evening at the curling rink." Ireland noted that there were 500 or 600 in attendance and that the crowd was very worked up. Ex-mayors of Range municipalities, former city attorneys such as Judge Montague, and other prominent local businessmen spoke at the meeting calling for and passing a resolution "practically unanimous, which in short is to deport the star strike agitators on this noon's train." Ireland opined that, "they will carry out the resolution by the spirit of the meeting last night." 261

On the same night as the citizens' committee meeting there was a mass meeting of strikers in Virginia's Socialist Opera House. Ireland, through labor spies, described the meeting as one in which, "the hall was crowded to overflowing, but everything was very peaceful, and [the strike leaders] advised the men to be peaceful and to not do any more than they would with their hands in their pocket." This was until strikers heard about the citizens' committee meeting and then according to Ireland, "when they got word of the resolution that was passed at the citizens' meeting, they said if the operators imported any gun-men, they would organize a vigilance committee and kill three of the operating force to one striker that was killed." ${ }^{262}$ There was probably such a warning issued at the

\footnotetext{
${ }^{261}$ James D. Ireland to M.A. Hanna \& Co., "Strike Situation Correspondence," June 16, 1916, Butler Brothers and M.A. Hanna Company Records Collection, Iron Range Research Center, Chisholm, Minnesota, Box MSS 158, Folder NE, Lake Superior-General—Labor Lake Superior Situation 1916, 8370 . ${ }^{262}$ Ibid.
} 
strikers' meeting as no one in the IWW disputed the utterance and the local press quoted IWW organizer Sam Scarlett as saying during a speech, "for every one of our members who is a victim of the gunmen who will doubtlessly be imported by the mining companies, three mine officials will pay the supreme penalty," 263 in response to the news of the formation of the citizens' committee and their plan to deport the strike leadership. Scarlett's "Eye-for-an-eye Speech" was probably orated to bolster confidence in the face of fears of violent vigilante justice. Citizens' associations, often backed by mining company managers, practicing vigilante justice had played significant roles in breaking past strikes in Colorado and Michigan. The IWW perhaps felt that strikers needed to feel that there was a robust defense of strikers to combat such vigilante organizations. The IWW intended to administer a peaceful strike, but clearly felt the need to let the mining companies and the Ranges' citizens' committee know that they would not be intimidated.

Thus, even though the IWW was preaching and attempting to practice peaceful protest during the strike, encouraging strikers to keep their hands in their pockets unless in fear for their lives, mining managers painted the IWW as violence-prone revolutionaries. The reality, though, was that the mining companies had used, continued to use, and planned for the future utilization of violence to run the IWW and their "agitators" off the Ranges. There was even a deportation of the IWW's organizers planned for in the near future. Mining company managers were relying heavily on the citizens' committee to solve the problem of the strike, and as of June 16, things looked good for a swift resolution to the IWW problem. That was on June 16; a day later things

${ }^{263}$ The Duluth News Tribune, June 16, 1916. 
had changed. As Ireland mournfully wrote to his handlers back at Hanna headquarters, “the citizens' committee did not eject the agitators yesterday, in accordance with the resolution passed the night before. I really thought they would, but I think they got cold feet." Or, perhaps the citizens' committee came to their senses and realized that what they were doing was illegal, immoral, and potentially deadly_-to themselves or members of the IWW. Dolefully, Ireland continued, "I suppose they wanted to wait until some accident or violence had been enacted; in other words, wait until the horse was stolen and then lock the door. As long as the agitators are in town there will be trouble. They are increasing their membership right along and taking the money, which, of course, is what they are after...I think if the outside agitators were removed from town, and forced to keep away, everything would be going smoothly in a couple of days."264

What Ireland failed to fully grasp or candidly admit in his rendering of the failed deportation plot was that the IWW likely bested the mining company managers at their own game. Through a massive system of intimidation and patronage, managers had kept local businessmen on a short leash. Local businessmen had often cowed to the interests of the mining companies, but according to Ireland the IWW "informed the businessmen that if they took any action against the strikers they would start a co-operative store [administered by the IWW], and boycott all the other stores."265

\footnotetext{
${ }^{264}$ James D. Ireland to M.A. Hanna \& Co., “Strike Situation Correspondence,” June 17, 1916, Butler Brothers and M.A. Hanna Company Records Collection, Iron Range Research Center, Chisholm, Minnesota, Box MSS 158, Folder NE, Lake Superior-General_Labor Lake Superior Situation 1916, 8370 . 265 Ibid.
} 
This was another example of the IWW's metis, or cunning intelligence, when administering and organizing the strike. The Wobblies had an effective ground game that constantly befuddled the mining companies, and men like Ireland, who believed that a bunch of rag-tag organizers leading a mass of uneducated rank-and-filers had no chance against the likes of the cultured, well-educated, and fully monied class. Ireland's contempt for the strikers reared its ugly head in multiple correspondences. In one such correspondence he wrote, "most of the men [the IWW] had in the line of March [strike parade] were not there from any special desire to strike, but simply went with the crowd, and are simple minded and easily lead." 266 Ireland had little understanding of the opposition or context of the strike: Finnish immigrants had a highly structured proletarian literacy and education program expressed in a robust hall culture that was opened to a multi-ethnic audience during the strike. At the same time, the IWW had developed effective, rhetorically dynamic multi-media tools for organizing and the solidarity that was lacking in previous strikes on the Minnesota Iron Ranges was a point of emphasis for the IWW and its multi-ethnic organizers.

The IWW also, perhaps, had the moral high ground—even according to Ireland. While the Independents and the Oliver had hired thugs willing to commit violence at their disposal, as evidenced by Ireland's own correspondences, the IWW had resisted the impulse toward violence. Meeting after meeting and speech after speech found the IWW advising a peaceful direction for the strike, if left unmolested. Ireland once again admitted as much writing on June 17, "the [IWW] speakers at the meeting asked the men

\footnotetext{
${ }^{266}$ Ireland to M.A. Hanna \& Co., "Strike Situation Correspondence," June 16, 1916. Author added Italics
} for emphasis. 
to keep quiet and not use any force," and "they are telling them to not use liquor, and giving them other good advice." ${ }^{267}$ Strange rhetoric for violence prone revolutionaries. Yet, the physical force employed by mining companies was seemingly an institutionalized violence advocated in all levels of management. A June 19 letter from Howard M. Hanna, Jr. to Ireland confirmed as much, "I am sorry that the businessmen and citizens of Virginia did not have nerve enough to throw the agitators out." Perhaps most disappointingly, these educated men of influence, power, and wealth knew they were acting in an ill-manner as Howard Hanna, Jr. signed off in his letter with, "I think it would be just as well to have you tear this letter up after you read it."268

With the opportunity to use the Ranges' citizens to do their dirty work gone, the mining companies had to find other methods of repression during the strike. Another such cog in the mining company managers' oppressive machinery was the local judiciary. On June 24, 1916, Ireland wrote of his approval regarding how some municipal judges were adjudicating during the strike. He confidently wrote to board members in Cleveland, "I must say that our municipal judge is very good at this time. He does not hesitate in giving good, stiff sentences. There were two fellows that threatened our timekeeper the other night, and the city police gathered them in and the municipal judge gave one of them ninety days at the work farm and the other thirty days." 269 Another municipal judge in

\footnotetext{
${ }^{267}$ Ireland to M.A. Hanna \& Co., "Strike Situation Correspondence,” June 17, 1916.

${ }^{268}$ Howard M. Hanna, Jr. to James D. Ireland, "Personal Correspondence,” June 19, 1916, Butler Brothers and M.A. Hanna Company Records Collection, Iron Range Research Center, Chisholm, Minnesota, Box MSS 158, Folder NE, Lake Superior-General_Labor Lake Superior Situation 1916, 8370.

269 James D. Ireland to M.A. Hanna \& Co., "Strike Situation Correspondence," June 24, 1916, Butler Brothers and M.A. Hanna Company Records Collection, Iron Range Research Center, Chisholm, Minnesota, Box MSS 158, Folder NE, Lake Superior-General_Labor Lake Superior Situation 1916, 8370.
} 
Eveleth, W. E. Moylan, belittled the IWW and its organizers when he commented while sentencing Ed Mattson for what was likely a trumped up public intoxication arrest, "Mattson is an I.W.W., but not of the worst type." He continued, "Mattson is not a dangerous character, but several offenses made punishment necessary. He is an I Want Whiskey agitator." ${ }^{270}$ Mining company managers like Ireland measured the worth of public officials and law enforcement personnel by their ability to demean, degrade, and deconstruct the positive aspects of working-class empowerment.

Not every municipal judge was opposed to giving the IWW organizers a fair shake, even if it took a little direct action to convince Justice to remain blind. In one such case a spirited assembly outside Chisholm's hall of justice made a convincing argument that an organizer arrested under suspicious circumstances should be set free. Ireland wrote of the affair, "you have undoubtedly seen that in Chisholm they arrested a man for assault and the judge gave him ninety days but the Chief of Police rushed in and told the judge to change it to a fine as there were 300 to 400 strikers outside and the Chief was afraid they would all be assaulted, so the judge did it."271

Ireland and the other mining company managers had to deal with the simple fact that a handful of the area's municipalities were administered by political Progressives, officials who were elected to office due to their oppositional attitudes toward the mining companies. Especially notable were Hibbing's Power and Virginia's Mayor, Michael

\footnotetext{
270 The Duluth News Tribune, July 1, 1916.

${ }^{271}$ James D. Ireland to M.A. Hanna \& Co., Agents, "Personal Correspondence," July 1, 1916, Butler Brothers and M.A. Hanna Company Records Collection, Iron Range Research Center, Chisholm, Minnesota, Box MSS 158, Folder NE, Lake Superior-General_Labor Lake Superior Situation 1916, 8370 .
} 
Boylan, who were ideologically antithetical to the power exerted by mining companies on the Ranges. Ireland had nothing but vitriol toward the Progressive mayors, once writing about Boylan, "Our mayor is a beauty. He was away when the strikers arrived in town, and the president of the [city] council, who is acting mayor in his absence, had all the saloons closed down, but when our major, Mike Boylan, arrived in town and took a walk down the street, he was very much surprised [at the closings] and asked the saloonkeepers why they were closed, and they told him, so he immediately told them to open wide, which of course they did." ${ }^{272}$ While these Progressive mayors caused mining company managers mental fits, they were at the same time opposed to the IWW's revolutionary perspective. Despite mining company reprimands that Progressives like Boylan and Power were acting in unison with the IWW, the Ranges' Progressives merely leveled the localized playing field between the all-powerful mining companies and the IWW.

This balanced representation of the electorate infuriated men like Ireland and his bosses back east and down the Great Lakes. While Power and Boylan were willing to let the IWW agitate and organize within the letter of the law, the mining companies wanted the wholesale eradication via a deportation of the IWW from the Iron Ranges. Added to the managers' dislike of the IWW's revolutionary industrial unionism was the antiimmigrant fervor of the World War I era. Many in industry attempted to portray the IWW's actions and ideology as seditious by implicating the IWW as German or Austrian Empire provocateurs. That the IWW was absolutely oppositional to monarchy made no

272 Ireland to M.A. Hanna \& Co., “Strike Situation Correspondence,” June 17, 1916. 
difference; the company line had the IWW, its organizers, and rank-and-file members as part of the Kaiser's standing army. Without evidence, Ireland opined that German money might be finding its way into the IWW's strike coffers, "and if there is no outside money back of this strike, it will soon be over, I think, tho some have thought there might be some German money behind it."273

In general, mining company managers were suspicious of immigrant labor and had poor opinions of these immigrant workers. Ireland expressed this disconnect with the difficult lives of industrial laborers when he wrote in a letter, "the men are just like sheep and while they have nothing to complain about the agitators get them excited and a number follow the leaders and the rest are afraid to work." Ireland's solution to get the men back under his control included the violence that so often plagued workers in North American labor-management conflicts, "Sheriff Meining prevents our deputies from going after the leaders and beating them up and as a matter of fact they are hard to get at." In this same plaintiff letter Ireland lamented the failed plan to deport IWW leaders, "the citizens talk of driving the I.W.W. leaders out of town but always end by saying that they have no right to and as our deputies are all under the Sheriff's orders he ties our hands while he plays both sides." 274

Ireland's correspondences to Hanna headquarters in Cleveland are an extraordinary, behind-the-scenes peek at management's nuts and bolts, dollars and cents,

\footnotetext{
273 James D. Ireland to M.A. Hanna \& Co., “Strike Situation Correspondence,” June 24, 1916.

274 James D. Ireland to M.A. Hanna \& Co., "Handwritten Personal Correspondence,” n.d., Butler Brothers and M.A. Hanna Company Records Collection, Iron Range Research Center, Chisholm, Minnesota, Box MSS 158, Folder NE, Lake Superior-General_Labor Lake Superior Situation 1916, 8370.
} 
assessment of the use of violence to prevent workers from striking. When writing about attempts to keep the strike in Minnesota from spreading to Hanna's iron ore mining properties in Michigan Ireland coldly wrote, "I think Mr. W. J. Richards expects a strike in Crystal Falls [Michigan] and if there are agitators coming there I believe that by organizing we can have them thrown out of town and kept out." In the same letter, Ireland did a cost-benefit analysis of preventative violence:

We can keep on working as long as the men will work and when they won't work we can shut down until they get hungry and save considerable expense, but if you do not want 350,000 tons or more and we have a strike we may have to go to a considerable expense to fight the thing through.

Also how far do you want to go in keeping the mines open?

Since you have said you may not sell more than 200,000 tons of Carpenter [Mine] ore you would not want to go to the expense of striker breakers and then have the ore left on stockpile at the close of navigation...if we have a strike at Wakefield [Michigan] I plan on only doing such work as is absolutely necessary in addition to mining the ore and if necessary post gun men all about the property and import strike breakers and things of all kinds to keep the strikers off and the job going at all costs. Now this will be expensive if we have to go to this extreme and I want to ask if you want to go to this extreme at the LaRue, Brunt and Sliver [mines in Minnesota]...I am going to Wakefield on Saturday and want to see the Sheriff and the various Superintendents and see if we cannot work some scheme 
to throw out agitators before they can get busy and work up a following as I hope that nothing like my Wakefield program will be necessary. ${ }^{275}$

\section{The Shooting of John Alar}

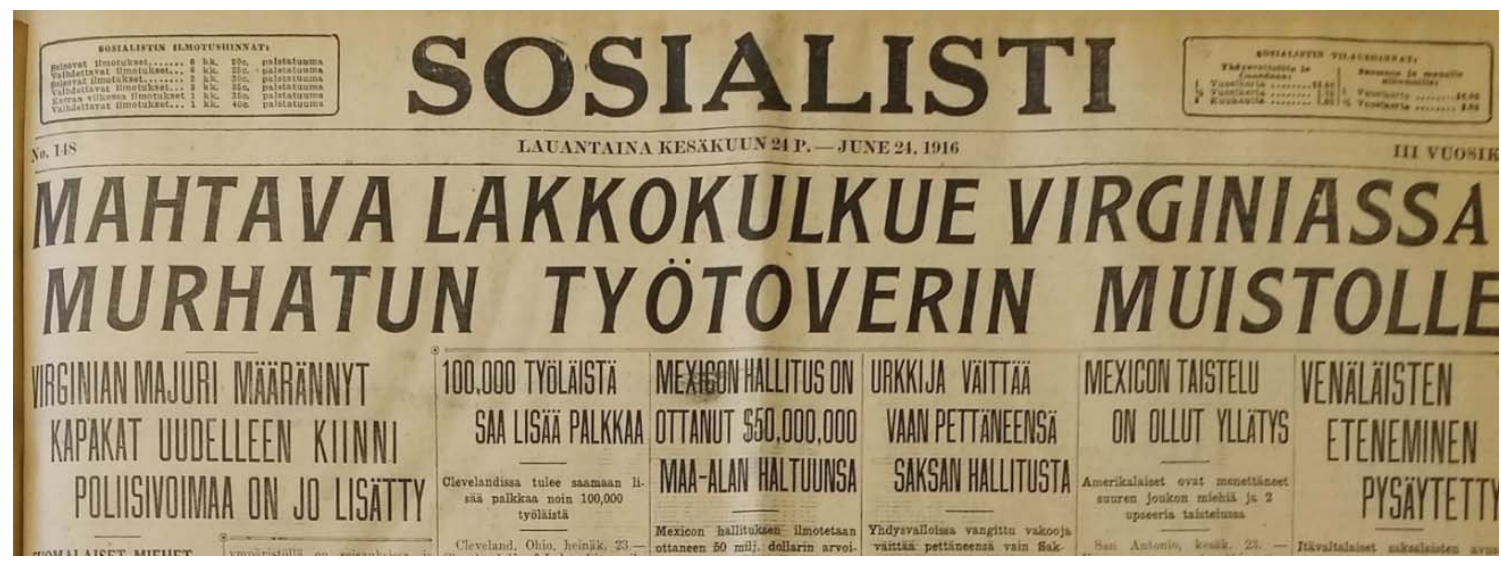

Figure 8.1-Banner headline from the Finnish language Sosialisti decrying the "Murhatun" or murder of John Alar in the streets of Virginia--Finnish American Historical Archive

As already demonstrated, mining company use of violence in the 1916 Strike was well-documented, but up to June 22 , that violence was mostly of the skull-cracking, nonlethal variety. That all changed with the death of John Alar, father of three and an immigrant striker from Croatia. The IWW, in the Strikers' News, was quick to charge the Oliver Mining Company with Alar's death:

John Aller [sic] was murdered by the Oliver Mining Company gunmen at his home near the property, Thursday, June 22, 1916, at 6 o'clock in the morning.

The strikers who were on the picket line on that morning say that the gun men deliberately walked into Aller's house and shot him three times in the back. John Aller was a married man and leaves his wife and three children, the oldest being

${ }^{275}$ Ibid. 
five years old and the youngest is an infant boy. They are orphaned because their father demanded a right for all of them to live. The strikers are supporting this fatherless family. ${ }^{276}$

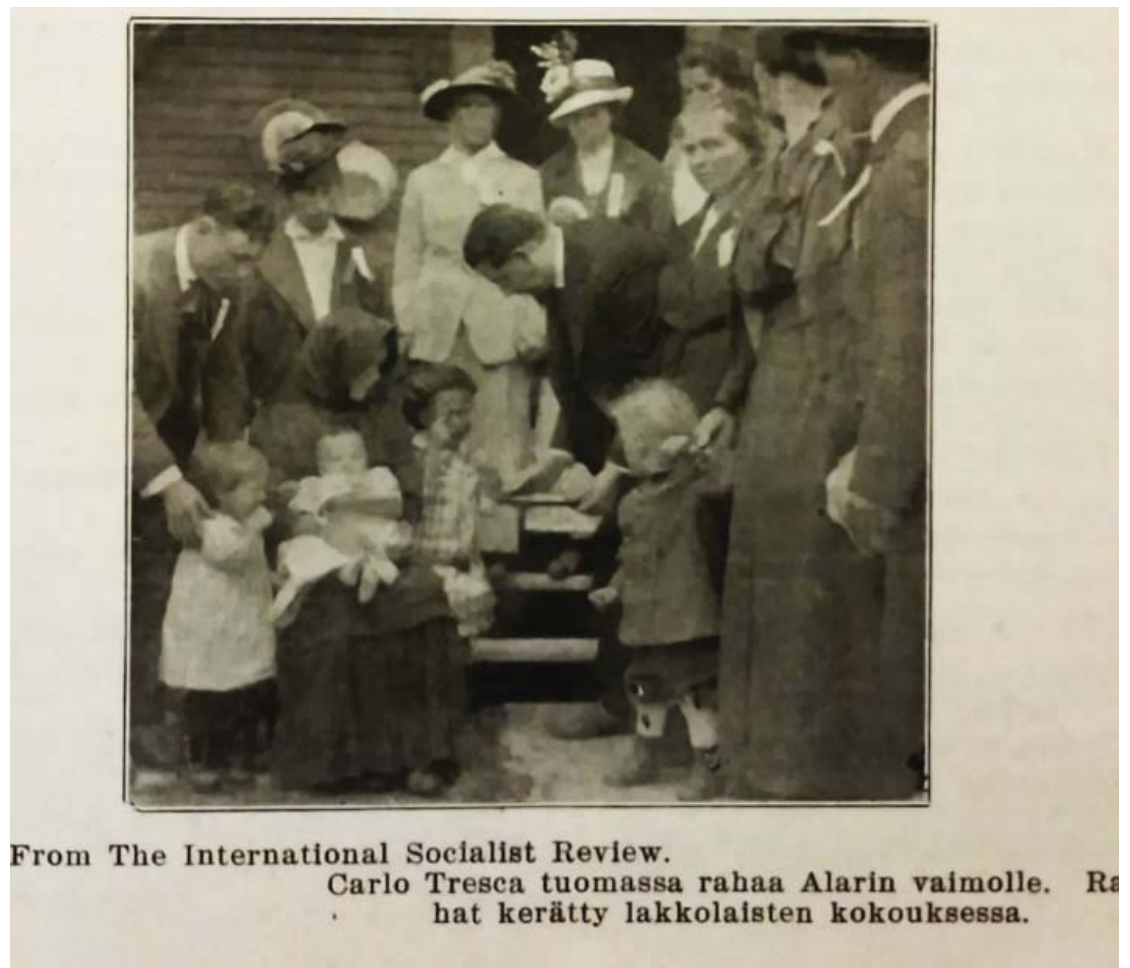

Figure 8.2-Image published in Ahjo, No. 6, 1916, whose caption in Finnish read, "Carlo Tresca bringing money to Alar's wife. The money was gathered during at strikers' meetings." The image shows Tresca bending over to talk with Alar's wife, in mourning cloak, and three children.

The company perspective was, of course, much different from the IWW's and Ireland wrote of Alar's death on June 23, “in yesterday's fracas there was one man killed and several badly wounded. It was a fight with clubs, bricks, rocks and guns. The man that was shot was on his knees aiming his gun at another man, and it seems the other man got their first. The man who was shot had a rifle and a revolver, so he was bent on

276 Strikers' News (Virginia, Minnesota), n.d. 
mischief alright." Ireland seemed especially displeased by women participating in the strike. He took the time to mention that "there were a number of women in the fracas also; one of them stepped out of her door and shot three times at the deputies. There were probably twelve or fifteen shots fired. One of our deputies got his in the breast with a brick, and he was spitting blood all yesterday afternoon."277

The Oliver's company police were concerned about the repercussions for shooting a man off company property. They sought out Sheriff Meining to give their side of the story as soon as possible, however according to Ireland, "Meining has disappeared....and is playing politics, puts all the blame on mining company deputies." Disgusted, Ireland retorted, "Meining is a yellow pup, and two years ago during the street car strike the Governor had to order him to get on the job or get off it." Ireland continued, "I feel that this trouble will not end until the Governor can be persuaded to put a regular man in as sheriff who will drive the I.W.W. agitators off the range."278

The Strikers' News chronicled the funeral rites and procession on Sunday June 26, which followed Alar's casket from Virginia's Socialist Opera House to the city's Catholic cemetery. "Fully seven thousand strikers accompanied the murdered brother to the cemetery," and the "Finnish Socialist band of Virginia played the funeral music and marched at the head of the parade. At the grave of John Aller [sic], funeral orations were delivered in all languages of the strikers." Alar's widow had requested the burial rites be given by a Catholic priest, but as the Strikers' News editorialized, "the priests, however, being loyal to the master class, refused to do so." Instead, IWW organizers administered

\footnotetext{
${ }^{277}$ Ireland to M.A. Hanna \& Co., "Strike Situation Letter," June 23, 1916.

${ }^{278}$ Ireland to M.A. Hanna \& Co., "Handwritten Personal Correspondence," n.d.
} 
the last rites to a multi-ethnic gathering in the cemetery. The strikers' newspaper went on to document that "the vast and imposing funeral was headed by a large banner carried by four women, upon which was inscribed: MURDERED BY OLIVER GUNMEN."279

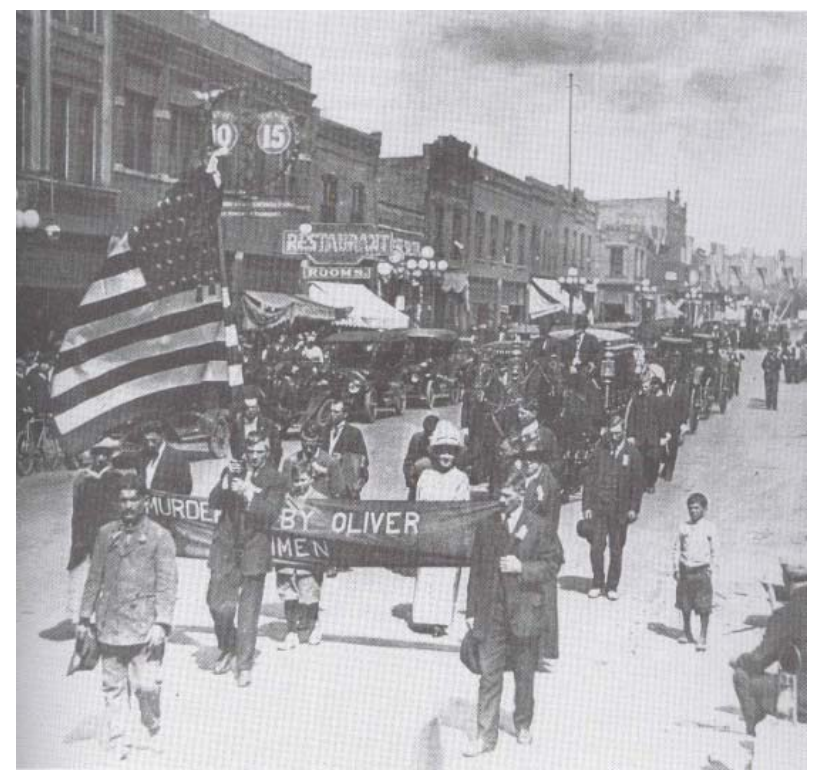

Figure 8.3-John Alar's funeral through the streets of Virginia, Minnesota--Pagliarini Collection, Iron Range Research Center

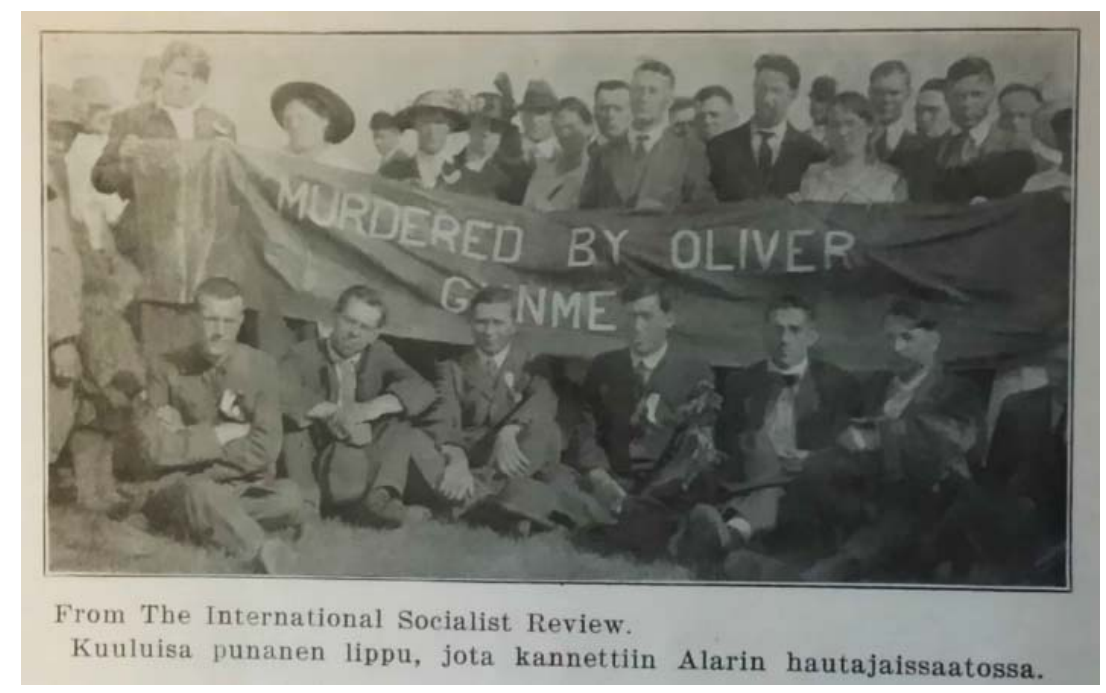

Figure 8.4-Image published in Ahjo, No. 6, 1916, taken from the International Socialist Review. The caption, which is in Finnish, reads "The famous red flag that was carried in Alar's funeral."

${ }^{279}$ Strikers' News, n.d. 
Predictably, Ireland was not impressed or moved by Alar's well-attended funeral. In fact, Ireland and perhaps the other mining company managers noticed the solidarity of the strikers coalescing and viewed this as an ominous sign. Ireland wrote of the funeral, "the authorities in Virginia told the strikers Monday that they could not carry red banners or obnoxious signs in the funeral procession Sunday, but they carried a great big banner extending from sidewalk to sidewalk on which was written 'Murdered by the Oliver Police,' and other similar signs." That strikers were able to assert their civil rights was a problem to Ireland as he complained in the letter, "the police at Virginia walked along side of the funeral and made no attempt to take the banner away." Ireland believed that the company police ought to be able to enforce law and order if the St. Louis County Sheriff was not going to do so: "the point I make is that if the city police and sheriffs do not feel that they can handle the situation they ought to call on the Mining Company's police for aid." 280

Unbelievably, no one ever served jail time for Alar's shooting. Perhaps more incredibly, there was not even a trial for shooting a man in the streets of the Iron Range's Queen City—Virginia. People did go to court in regards to the Alar shooting. Those people were not, however, involved in the actual violence. IWW organizers Sam Scarlett and Carlo Tresca were both charged with criminal libel for carrying the "Murdered by Oliver Gunmen" banner. A news article regarding the trial related, "the trial of Carlo

\footnotetext{
${ }^{280}$ James D. Ireland to Virginia Ore Mining Company, "Personal Correspondence," June 28, 1916, Butler Brothers and M.A. Hanna Company Records Collection, Iron Range Research Center, Chisholm, Minnesota, Box MSS 158, Folder NE, Lake Superior-General—Labor Lake Superior Situation 1916, 8370.
} 
Tresca, Italian strike leader, and Sam Scarlett, chief leader of the striking miners on the Mesaba range, was set for Wednesday, July 5, before Municipal Judge James P. Carey. Tresca and Scarlett are charged with criminal libel of the Oliver Iron Mining Company for carrying the banner...over the principal streets of the city in the John Alar funeral procession." 281

The mining companies' first move after the Alar shooting was to gear up for an offensive against the IWW by consolidating the various companies' police forces. Ireland wrote of the plot to orchestrate the activities of the area's gun thugs and heavies in a personal letter to agents at Hanna headquarters, "Mr. Mather [of Pickands Mather] urged very strongly that we join our forces together, saying Mr. Colby and others were in New York urging the Steel Trust officials to take a more active part in the suppression of the I.W.W." ${ }^{282}$ Lamenting the fact that some of the best men for the job of suppressing the IWW were already gone, Ireland wrote that "the Sheriff, the Oliver Iron Mining Company police and the militia have taken out most of the available men in this part of the country that are suitable for police, but of course we could gather any number of men together in Michigan." Ireland noted that there was a problem with bringing in men from the outside referencing the 1913-14 Michigan Copper Strike, "tho there is always an objection to transporting police from another state, and that was quite a question in the Copper Country strike. However, if the sheriff authorized us to do this it would be all right." ${ }^{283}$ Despite the aforementioned concerns, Ireland signed off on hiring twenty-three

${ }^{281}$ The Duluth News Tribune, July 1, 1916.

282 James D. Ireland to Virginia Ore Mining Company, “Typed Personal Correspondence,” June $28,1916$. 283 Ibid. 
deputies at \$5.00 a day in pay for the Virginia Ore Mining Company’s private police force-a mere platoon in the mining companies' private army on the Ranges. ${ }^{284}$

The legalities of importing men, paid by M.A. Hanna \& Co., who would be acting in the interest of the mining companies, yet who were deputized by local authorities to police public spaces concerned the men back at Hanna headquarters. Legal liability and public scrutiny were a concern. There was a good deal of nuance in dealing with such legalities and Ireland wrote of these legal intricacies:

In answer to your question as to how our police force are sworn in...the deputies take an oath that they will uphold the laws of the State, etc., and are sworn in as deputy sheriffs and not [company] police, and when sworn in they are the assistants of the sheriff of St. Louis County...[they] must obey any instructions that he gives them, but until he calls on them for special work they are under the orders to protect our properties.

Thus, if the sheriff or any of his assistants take our men to the other properties to protect them, presume that they are expected to use their judgment and obey the sheriff's orders when they are on these other properties, so that I do not see how our Companies can be held responsible for their acts if the sheriff calls on them. ${ }^{285}$

\footnotetext{
${ }^{284}$ James D. Ireland to M.A. Hanna \& Co., "Strike Situation Correspondence," July 1, 1916, Butler Brothers and M.A. Hanna Company Records Collection, Iron Range Research Center, Chisholm, Minnesota, Box MSS 158, Folder NE, Lake Superior-General—Labor Lake Superior Situation 1916, 8370, and James D. Ireland to M.A. Hanna \& Co., Agents, "Business Correspondence," July 3, 1916, Iron Range Research Center, Chisholm, Minnesota.

${ }^{285}$ Ireland to Virginia Ore Mining Company, “Typed Personal Correspondence,” June 28, 1916. 
Despite the recruitment, feeding, and arming of a small, private army, mining company managers were losing ground in combatting the influence of the IWW on the Ranges. Adjudicating the IWW off the Ranges was not working, the citizens' committee plan to deport the IWW failed, company police had just shot a striker and the IWW membership had made the man into a martyr, and the St. Louis County Sheriff was not as firmly tucked in the mining companies' back pockets as expected. It there was ever a time for the mining companies to play their trump card, it was now.

\section{A Proclamation from St. Paul}

The effects of the strike were beginning to take hold on the Ranges. The streets of Range municipalities were filled with idled striking workers. Former Finn Halls were the sites of raucous, empowering working-class rhetoric, and solidarity was increasing between the Ranges' many nationalities. Ireland and the other mining managers were flummoxed with how to deal with the IWW's organizing successes and the inability of the companies' tactics to dissuade organizing activity. Writing in one letter Ireland complained, "just arresting these fellows and letting them out on bail does no good." He continued, "in fact the last agitator arrested made a speech in which he thanked the officers for arresting him as he said he did not have money enough to employ a press agent and this free advertising was exactly what he wanted."286

The strike was also beginning to severely bite into profits during a World War Iera mining boom by affecting production and the Ranges' experienced labor force. Ireland protested in one letter that "up to Wednesday night 600 miners who want to work

${ }^{286}$ Ireland to M.A. Hanna \& Co., Agents, “Personal Correspondence,” July 1, 1916. 287 
left the Hibbing district for districts that are quiet, and it is estimated that up to that night 2000 men had left the Mesaba, and this, to our minds, is the most serious thing of all, because even if the strike were broken in the near future it will mean that a great number of men will have left the range." ${ }^{287}$ As Ireland was indicating, time was of the essence. The strike had to be broken and in the hopes of preserving the mines' experienced work force, post haste.

Noting that the Oliver and the Independents were losing control of the Ranges, Ireland wrote plaintively on June 28 that "if the sheriff does not feel strong enough to handle the situation it is either up to the government to put in a sheriff who will or to provide some means for enforcing laws." Ireland charged that mining companies had restrained themselves so far and that it was only the strikers who had been prone to acts of violence. Indicating that there was perhaps a tipping point coming, Ireland and other mine managers were seeking advocates and allies in high places, "Mr. Munger [and myself will] try to get a number of prominent citizens to go to the Governor and insist that he insist on more forcible action by the sheriff and that the leaders be arrested for starting riots and making threats to kill people and be kept where they can stir up no more trouble for a while." Ireland closed out the letter with a handwritten postscript to the typed letter, "I will meet the Governor in St. Paul tomorrow at his request. Also Sheriff Meining."288

Thus, the die was cast. Oliver and the Independent mines were unable to quash the resilience of the IWW and its rank-and-file and the mining companies were at a

\footnotetext{
${ }^{287}$ Ireland to Virginia Ore Mining Company, “Typed Personal Correspondence,” June 28, 1916. ${ }^{288} \mathrm{Ibid}$. Italics are from the author and used to express emphasis regarding the quote. 
desperate crossroads. They needed to appeal to a higher authority-Minnesota's Republican Governor Joseph A. A. Burnquist. The mining companies needed the Governor to act as a political thug for their financial interests and sadly Burnquist was more than willing to oblige. The Governor's actions and the consequences that sprang from his actions would change the course of the strike, as well as how Minnesota and the United States would deal with organized labor, immigrants, political discontent, and basic civil rights for many years to come.

Less than a day after Ireland's meeting with the Governor and Sheriff Meining, Minnesota's highest elected official sent a telegram to the Sheriff, a proclamation issued on June 30, 1916, from the state capital in St. Paul that read:

John Meining, Esq.

Arrest forthwith and take before magistrate, preferably in Duluth, all persons who have participated and are participating in riots in your county and make complaints against them.

Prevent further breaches of the peace, riots and unlawful assemblies.

Use all your powers, including the summoning of posse, for the preservation of life and property.

The Violation of law in Saint Louis County must be stopped at once. ${ }^{289}$ Burnquist's telegram to Sheriff Meining was utter and shameless political theater. There was actually a good chance that Meining was still in St. Paul on the heels of his June 29 meeting with Ireland and the Governor when the June 30 telegram was

${ }^{289}$ The Duluth News Tribune, July 1, 1916. 
supposedly sent to Meining in Duluth. The Governor had a staffer make another call to northern Minnesota on June 30, but this call went to Hibbing Mayor Victor Power. In this call to Power, Burnquist was likely attempting to gain compliance or drum up support for his missive from the Ranges' leading Progressive. Power's journal recorded the call, but also noted that "I.W.W. leaders called." 290 The Wobblies, like many in Minnesota, recognized the significance of the Governor's proclamation and were likely attempting to gauge Power's reaction to the Governor's inflammatory decree.

While Burnquist's proclamation was an inflammatory bit of political theater, rhetorically it was a savvy application of mass communication. The proclamation was not going to pull on any heart strings, nor was it particularly steeped in legal "truths"; it was however from the state's Governor and this gave the missive great credibility. The proclamation was an ethos-driven communique distributed on a statewide scale. Additionally, the office of Governor held great significance because it was an elected position and the proclamation to arrest and take the IWW "rioters" before the magistrate held pronounced clout because it seemingly had the approval of all those people who had voted for Governor Burnquist. The Governor was using his power as the executive of the State of Minnesota to indicate that most of Minnesota was fed up with the alleged lawlessness of the strike and this was a powerful message to strikers, but also to those who would execute the Governor's proclamation.

The political theater that surrounded Burnquist's proclamation and his allegiances to the mining companies might merely be dismissed as supposition, but Ireland

\footnotetext{
${ }^{290}$ Victor L. Power, “Personal Journal Entry,” June 30, 1916, Victor L. Power Papers, Minnesota Historical Society, St. Paul, Minnesota, Box 1.
} 
documented the meeting's existence and subjects, creating a record of the whole-sale jettisoning of democracy and justice on the Ranges. In a June 30, handwritten letter to his handler's in Hanna's Cleveland offices, Ireland gloated (to avoid any misinterpretation of the document, the entire letter is transcribed below):

We held a meeting in the Wolvin Bldg on afternoon of $28^{\text {th }}$ at which Messers. Olcott, McGonagle, House, Frank Adams, Billings, Sutes, Munger and I were present and it was decided that since the Oliver I.M.C. had presented their views on the strike situation to the Governor it was time for the Independents to back it up and the Governor was in a receptive mood.

Accordingly John Sutes and I went to St. Paul on Thursday night and met McGonagle and Sabernious then in morning. Sheriff Meining had been ordered by the Governor to be there at nine that morning also.

By eleven that morning we had got in the Governor's office and as Sutes had already talked to Meining and made our peace with him, he acted very well and backed us on things we told the Governor about strike conditions.

We told the Governor that the men were leaving the Mesabi in great quantities because of foreign labor leaders who incited riot and fear and that these leaders must be taken out of the state if order is to be restored and this must be done promptly or all our better class of men will leave.

That the Governor should come out with a very strong proclamation declaring that law and order must be enforced and the Sheriff would have the full power of the state to enforce it and if he could not then the Governor would send the militia to the Range and do it for him. 
The Governor said that he had almost made up his mind to these very things and after going over the matter with the Sheriff it looked as if he was going to get busy right away.

After lunch I went to McGonagle's room at hotel and met the Governor in hall as he was coming to lunch with McGonagle and Sabenious and to talk things over.

McGonagle tells me that the Governor will probably do these things if he can get started before some newspaper gets hold of it, but if the politicians find out what he has in mind it won't be done until he has to do it. Therefore we are keeping very quiet about this in hopes that he will act soon.

The Governor was glad to see Sutes and I representing the Independents and if he would only do the things that he acts as if he wanted to do, the strike would be over in 24 hours.

Frank Adams said today that the Governor told Sabenious this afternoon that he had given orders to the Sheriff to arrest all strike leaders and bring them to Duluth and keep them off the range and that if the Sheriff don't do it he will appoint another sheriff.

I am curious to see if he will do this or not.

Please do not let this get out because if it gets out the Governor will back water I know. He means well but is very near election and everyone has an axe to grind. ${ }^{291}$

${ }^{291}$ James D. Ireland to M.A. Hanna \& Co., "Personal Correspondence," June 30, 1916, Butler Brothers and M.A. Hanna Company Records Collection, Iron Range Research Center, Chisholm, Minnesota, Box MSS 
The fix was in. And, consequently, the supposed "riotous and fear" inciting IWW organizers, who Ireland backhandedly complemented for their ability to strike peacefully "with hands in their pockets," were about to have their basic human rights trampled. Minnesota's Governor was acting solely in the interests of the Oliver Iron Mining Company and the handful of additional independent operators. There is ample evidence for this and one needs look no further than the text and tone of the Governor's June 30 proclamation, which was taken almost entirely from the attitudes, interests, and opinions expressed by mining company officials during their meeting with the Governor. Thus, Minnesota's highest elected public official was set to publicly order the Sheriff of Minnesota's third most populated county to deport and incarcerate the IWW's strike leadership. In the parlance of a Minnesotan dialect, "Yah, you betcha," the Governor of Minnesota initiated a plot to stomp on the Bill of Rights, illegally deport and imprison (for an unspecified time) IWW organizers, and fire St. Louis County's sheriff if his plan to help the mining companies break the strike was not followed to his liking. Furthermore, the Governor had promised in private to send the publicly funded state militia to solve the mining companies' labor problems. Perhaps just as corrupt and immoral, the Governor did all of this under the cloak of secrecy in the hopes that his fellow politicians, nor the media, would catch wind of his plan and thus effect his chances of being reelected.

Ireland's meeting with Burnquist had gone very well indeed. Ireland was giddy with praise for the Governor and his proclamation as a July 1, 1916, letter to a colleague

158, Folder NE, Lake Superior-General-Labor Lake Superior Situation 1916, 8370. As the letter is handwritten some of the fore and surnames may not be accurately transcribed from the letter. 
demonstrated, "Burnquist has taken a very decided stand against the agitators, and has given the sheriff strict orders to disarm all strikers and arrest the I.W.W. agitators.

Governor Burnquist has a decided, strong character, and I feel very positive that now he has taken it into his hands, the strike has passed its climax." ${ }^{292}$

In a triumphant late night telegram to Hanna Company officials on July 1, composed of fragmented sentences and thoughts, Ireland proclaimed that, "Governor issued proclamation ordering sheriff arrest all persons who have or are participating in riots or unlawful assemblies and chief police Duluth says wont [sic] allow agitating in Duluth. County Attorney says will back sheriff up and maximum penalty five years Stillwater [State Prison]." Ireland was certain to inform the company officials that the Governor's missive "will kill strike and don't believe any danger of strike on docks." 293 Newspapers across the state heralded Burnquist's farcical telegram. The Duluth News Tribune, which Ireland insisted was a "slut" earlier in the strike, proclaimed in front page, all caps lettering that, "MINNESOTA'S YOUNG EXECUTIVE DIRECTS ARREST OF AGITATORS." The newspaper went on to explain, "Hibbing and Virginia hear that Deputy Sheriffs will today being disarming of every striker-George Andreytchine, one of I.W.W. ringleaders locked up—mob forms at Kinney, but John A. Keyes, lawyer of Duluth, and Carlo Tresca warn it against violence.”294

\footnotetext{
292 James D. Ireland to M.A. Hanna \& Co., "Strike Situation Correspondence," July 1, 1916, Butler Brothers and M.A. Hanna Company Records Collection, Iron Range Research Center, Chisholm, Minnesota, Box MSS 158, Folder NE, Lake Superior-General—Labor Lake Superior Situation 1916, 8370.

${ }^{293}$ James D. Ireland to M.A. Hanna \& Co., "Western Union Telegram," July 1, 1916, Butler Brothers and M.A. Hanna Company Records Collection, Iron Range Research Center, Chisholm, Minnesota, Box MSS 158, Folder NE, Lake Superior-General—Labor Lake Superior Situation 1916, 8370.

${ }^{294}$ Ireland to M.A. Hanna \& Co., "Strike Situation Correspondence," July 1, 1916.
} 
Though the IWW's stance on violence in the face of a terribly skewed proclamation remained the same, and while Sheriff Meining had finally succumb totally to the power and reach of the mining companies, the Ranges' municipalities under the purview of Progressive politicians continued the fight against Burnquist's anti-union campaign. Even though the highest authority in the state had unfairly and unilaterally tipped the scales of justice toward the mining companies, Ireland found contempt in how the municipalities attempted to guard an egalitarian, unbiased sense of justice. In yet another "Strike Situation" communique back to Hanna headquarters, he wrote on the day of the Governor's supposed telegram to Meining, "there was a stabbing around Hibbing last night, but the trouble with the towns is that the police insist that it is their province to keep order in the towns and they do not want the sheriff to interfere, but they fail to keep order and fail to keep the strikers from intimidating the men who desire to work." While Ireland now found great fault with local municipal police, he did not have a bad word to write about Sheriff Meining. After the meeting with the Governor and Meining, Ireland found complete confidence in the once termed "yellow pup" Meining and was "in hopes that the Sheriff will take things in his own hands and get control of the situation in the towns as well as in the county, and thus have the entire situation under his control." 295

Ireland, and mining men like him, got what they wanted: a means to rid the Ranges of the IWW. With Burnquist advocating the arrest and deportation of the IWW leadership, others began to jump on the bandwagon. The same issue of The Duluth News

\footnotetext{
295 James D. Ireland to M.A. Hanna \& Co., "Personal Correspondence," June 30, 1916, Butler Brothers and M.A. Hanna Company Records Collection, Iron Range Research Center, Chisholm, Minnesota, Box MSS 158, Folder NE, Lake Superior-General-Labor Lake Superior Situation 1916, 8370.
} 
Tribune that ran a banner headline about Burnquist's declaration also noted that "citizens and mining men of Virginia have asked Brown McDonald, immigration officer at Duluth, to come to Virginia and investigate the aliens. More than 90 per cent of strikers are not citizens and the plan Virginia people have in mind is to deport strikers."296

Mining companies and their hired hands across the Ranges were trying everything to put down the strike: there was the customary use of violence in an attempt to beat IWW organizers from the Range, they had hired high paid gun thugs to direct their campaigns of violence, they attempted to persuade and reinforce a citizens' committee to deport IWW officials and now "aliens," and then finally an IWW member, John Alar, was shot under suspicious circumstances. All of this had failed to beat the IWW from the Ranges. Though the mining companies had Minnesota's highest elected official in their pockets, they were still concerned about gaining control of the Range's immigrant workforce. Ireland wrote after the Governor's proclamation, somewhat bewildered and taken by innuendo that, "one of the worst features [of the strike] is that the Italian agitator, Tresco [sic], and his lieutenants are spreading the rumor among the Italians that they are the officials of a society similar to the 'Black Hand' and that they have a secret organization equal to none and that if the Italians work they will get them even if it takes seven years." 297

Echoing more strains of paranoia, Ireland also wrote that the Austrians and Germans were out to get the mining companies' workers as well. With a sense of finely crafted suspicion Ireland wrote, "the secret Austrian Associations have notified the

296 The Duluth News Tribune, July 1, 1916.

${ }^{297}$ Ireland to M.A. Hanna \& Co., "Personal Correspondence," June 30, 1916. 
Austrians that if they work in a district where a strike is called they will henceforth not participate in any of the Society's benefits, and it looks as if these orders were from the Austrian Counsel. If such is the case there is certainly grounds that Germany may be responsible for it." ${ }^{298}$ Ironically, it was Ireland, the mining companies, and Burnquist who were actually perpetrating most of the cloak-and-dagger chicanery on the Ranges. The so-called secret immigrant societies were not a secret to anyone with the possible exception of the mine bosses. The solidarity formed in these societies had nothing to do with the Kaiser or some ridiculous bosses' war in Europe. The fraternal and benevolent societies of the Ranges' immigrant groups existed because of the unequal distribution of wealth on the Ranges and especially in times of labor conflicts these immigrant organizations, born of class struggle, would not extend benefits to workers scabbing while a strike was occurring.

Even in the face of the repressive actions of the mining companies and their Governor, the strike was not flaming out. The only aspect left wanting for mining company managers was an incident to put the Governor's plan into action. Such an incident was in the offing and the secrecy around the event or events was of primary concern. The same day as the Governor's proclamation, Ireland wrote to Hanna headquarters advising, "I enclose herewith three sheets giving a lot of words, and if you receive any telegrams from me with foreign words in them you can pick these words out of this code." ${ }^{299}$ Ireland was now employing coded messages in his communiqués. In yet another letter to Hanna headquarters on July 1, which discussed strikers' efforts to disrupt

\footnotetext{
${ }^{298}$ Ibid.

${ }^{299}$ Ibid.
} 
transportation, Ireland seemingly predicted that something was in the offing regarding the strike situation: "this morning the strikers stopped the trolley cars loaded with men going to work and they made the men get off the cars, but I think that the next day or two will make a difference." ${ }^{300}$ Sadly, Ireland's prognostication was eerily prophetic and an event that changed the entire course of the strike occurred just two days later-with deadly consequences.

\section{Framing-up the Mosonoviches}

The brutal truth of the Governor's proclamation was that it provided mining company thugs with a reason and the sanctioning to use violence in fulfilling the aims of the Governor's missive. The only ingredient missing from this conspiracy stew was an incident to precipitate action. The IWW's organizers had been arrested, stood trial, and were imprisoned before, but mostly at the purview of local and municipal governments. Wiley in the ways of law and order, IWW "agitators" such as Tresca and Scarlett tended to stay surrounded by striking workers nestled in the boundaries of local municipalities. The Governor's proclamation, however, likely emboldened the mining companies' private army and pressured an embattled Sheriff Meining into forcing an action to justify the Governor's words.

This action came on July 3 when a group of mine guards busted into the boardinghouse of strike-supporting Montenegrin immigrants Melitza and Filip

\footnotetext{
${ }^{300}$ James D. Ireland to M.A. Hanna \& Co., Agents, "Personal Correspondence," July 1, 1916, Butler Brothers and M.A. Hanna Company Records Collection, Iron Range Research Center, Chisholm, Minnesota, Box MSS 158, Folder NE, Lake Superior-General—Labor Lake Superior Situation 1916, 8370.
} 
Mosonovich. ${ }^{301}$ The company thugs, acting as deputy sheriffs, were supposedly

executing a search for an illegal liquor operation in the Mosonovich's Chicago Location home within the municipal limits of Biwabik. The intruders entered the Mosonovich home without a valid search or arrest warrant. The primary officer in the raid was Nick Dillon who was reportedly a former bouncer at a house of ill-fame with a bad reputation among strikers as a first rate company thug. Along with Dillon, John Myron, Mike Shubiski, and two or three other officers, notified Melitza that they had come to take her husband, Filip, and a boarder, Joe Hercigonovich, to jail. Melitza balked stating that only Biwabik’s Village Marshall, "Old Man” O'Hara, had the right to remove the inhabitants from their home. Dillon, almost certainly emboldened by the Governor's proclamation, was not going to take no for an answer. What ensued was chaotic and deadly. ${ }^{302}$ According to Melitza's own words, documented in an issue of the International Socialist Review:

Dillon was standing near door to bedroom and I went to bedroom to get Filip's shoes and Nick he says, "Ope," and I says, "What ope means, I am going to get shoes for my husband." Then Nick Dillon he got a hold of me and threw me into the bedroom onto my baby. If [my older] boy had not happened to be there I would have [landed on and] killed the baby. I spit blood for three days after. I told Nick to get out of the house and chased him out. I went outside after him and one

\footnotetext{
301 This surname is spelled Mesomovich in the International Socialist Review, but the name is also written as Masenovich or Masonovich in some publications. This dissertation will use the most commonly used spelling, Mosonovich.

${ }^{302}$ Otto Christensen, "Invading Miner's Homes," in International Socialist Review, Volume 17, (Chicago: Charles H. Kerr Publishing Co., 1916), 161-162.
} 
of those fellas with him hit me over the head with club. Then all the fellows in the house started to hit Filip and the boarders with the clubs. Nick he started to shoot from the yard. ${ }^{303}$

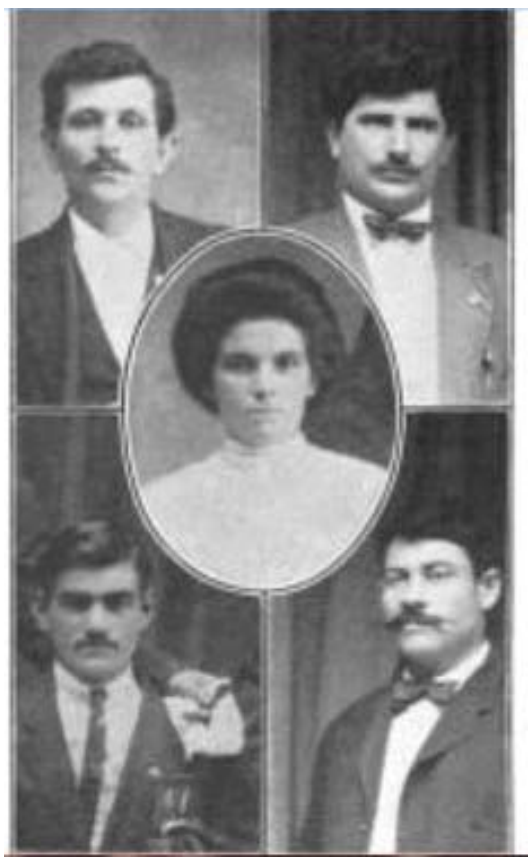

Figure 8.5-The inhabitants of the Mosonovich boarding house-in the center Militza Mosonovich, and clockwise from top left: Filip Mosonovich, Gaviolo Orlandich, Jovo Hercigonovich, and Joko Nikacfrom the International Socialist Review, Vol. 17.

What transpired next is even more difficult to reconstruct, but evidently a brawl erupted as the officers and the inhabitants of the Mosonovich boarding house began fighting. Guns were drawn. In the escalating scrape, one of the deputy sheriffs, John Myron, and a passerby selling soda pop, John Ladvalla, were shot dead. A boarder in the Mosonovich house was also shot-twice through the thigh. The Mosonoviches and their boarders, Joe Hercigonovich, John Orlandich, and Joe Nikich, all swore that they did not

${ }^{303}$ Christensen, "Invading Miner's Homes," 162. 
have guns. The only people in the fracas known to have firearms were the deputy sheriffs. According to the International Socialist Review, Shubiski admitted to firing shots into the house during a trial, "one of the guards by the name of Schubisky [sic], when testifying before Judge Smallwood, admitted that he fired several shots and that he fired them in the house, but no bullets or bullet holes were to be found in the house." 304

It never became clear "who actually shot John" or anyone else, but as Myron was standing in a doorway to one of the boarding house's rooms, reportedly beating Orlandich, he was shot three times in the back. The IWW and International Socialist Review blamed Shubiski, who admitted to firing his gun more than once, but the five immigrant inhabitants of the boardinghouse were arrested and charged with the first degree murder of John Myron. Ladvalla, a supporter of the strike, was struck by a stray bullet as he had stopped to gawk at the fracas occurring in the house. Apparently, the authorities did not care that much about Ladvalla because no one was ever arrested for shooting him. ${ }^{305}$

What happened next defied logic, but in some weird law and order alchemy facilitated by Governor Burnquist's proclamation, IWW strike leaders were also arrested for the murder of John Myron. As an article in the International Socialist Review remarked, "seven organizers for the I.W.W. stationed at distant points on the Range, were arrested without warrant, refused a hearing, placed on a special train, taken to Duluth seventy miles distant, and lodged in the county jail charged with murder in the first degree." The article went on to surmise, "under a peculiar Minnesota statute these

\footnotetext{
${ }^{304}$ Ibid.

${ }^{305}$ Christensen, “Invading Miner's Homes," 162, and Lamppa, Minnesota's Iron Country, 213-214.
} 
organizers are charged as principals in the murder of the deputy sheriff on the ground that speeches made by them induced the killing." 306

Up and down the Mesabi Range IWW organizers were arrested. In the light of day, in the dark of night, a massive sweep to drive the IWW from the Ranges commenced. Local organizers such as the Stark brothers were arrested, while in Virginia seven national organizers including Scarlett and Tresca were arrested. As the International Socialist Review concluded, "the basis for holding Tresca, Scarlett, Schmidt, Ahlgren and Wassaman is that they told the men in their speeches what their legal rights were in the defense of their home." The IWW organizers' instruction to keep strikers' hands in their pockets unless in fear for life or home mattered not and "this advice that is attributed to have been given to the strikers forms the prosecutor's inference that a conspiracy existed to resist mine guards and that this advice was the important influence that induced the Montenegrin strikers to resist Nick Dillon's detachment of mine guards." 307

For Tresca, his experiences prior to the Mosonovich affair were somewhat business as usual. He had been arrested, imprisoned, and had feared for his life numerous times in Italy and the United States. The twenty-four hours between July 3, and July 4, 1916, however, was a day like none other leaving Tresca to write from a St. Louis

\footnotetext{
${ }^{306}$ George P. West, “The Mesaba Strike," in International Socialist Review, Vol. 17, (Chicago: Charles H. Kerr Publishing Co., 1916), 160.

${ }^{307}$ Christensen, "Invading Miner's Homes," 162.
} 
County jail cell in Duluth, "it was about 10 o'clock in the morning... and I could tell myself that one day of my life was completed. T'was a crowded day indeed."308

July 3, 1916, started with Tresca and two companions taking a grocery delivery truck to Grand Rapids, Minnesota, county seat of Itasca County, in an attempt to bail local IWW organizer George Andreytchine out of jail. Andreytchine had been attempting to fan the flames of discontent in the Itasca County mines and was arrested by an Itasca County deputy sheriff. Tresca was under the impression that he could use money to entice Itasca County officials to let Andreytchine go. According to his autobiography, Tresca felt he was making headway in the attempt to loose Andreytchine from the bonds of Itasca County, until he began to sense an overwhelming "lurking danger" that he might be arrested. As he was seated in the Itasca County District Attorney's office having a "nice...polite chat" his premonition seemed to be coming true as the Itasca County sheriff busted through the District Attorney's office door “in shirtsleeves with a belt of cartridges around his belly with one gun on his hip ferocious looking, with two husky deputy sheriffs at his heels. The man was red in the face, and without introduction began to shout, 'You goddam agitator, what did you come here for?"309

Tresca, almost predictably, did little to relieve the tension as the sheriff had a deputy pat him down to look for guns and ammunition. Tresca had none, which seemed to raise the sheriff's ire even more. After the search, the district attorney asked the sheriff for a sidebar in another room and when the two reappeared it seemed that Tresca was free

\footnotetext{
308 The Carlo Tresca Papers, “Autobiography,” 1879-1943, (Microfilm), Italian American Collection, Immigration History Research Center, University of Minnesota, 238.

${ }^{309}$ Carlo Tresca Papers, 229.
} 
to go. He gave the formerly courteous district attorney a good-natured good-bye and the district attorney responded, "get the hell out of here you S.O.B." Taken aback, Tresca was about to respond when "he felt the muzzle of the sheriff's gun at [his] back" and the sheriff began to shout, "Get out, get out!"310

Tresca and his two acquaintances got back in the little grocery truck and were heading east for Hibbing, where there were a number of gatherings in support of the strike scheduled for that night. As they were leaving town, the intrepid trio noticed that they had company. Looking out the side of the truck Tresca noted that a car containing the sheriff and another car were in pursuit. After driving another block or more, Tresca noticed that three more cars had joined the unfriendly motorcade. Noticing that the men were armed with rifles, Tresca advised the driver of the truck to keep going without delay and that the sheriff was probably just giving the grocery truck an escort to the county line. $^{311}$

However, upon reaching the small mining location of "Mishaevaka," the three travelers noticed "two columns of men, some armed with rifles," flanking both sides of the location's main street. One of Tresca's traveling companions leaned over to him and stated, "this is a lynching party for you." Tresca got out of the car and walked behind the automobile as a way of taking the heat off of his two traveling partners. The gauntlet of men began to shout at Tresca as he walked in back of the car, "DAMNED AGITATORSUCKER—DAMN FOREIGNER, GET THE HELL OUT OF HERE!” Tresca noticed that behind the angry mob was a group of strikers offering encouragement, and more

${ }^{310}$ Carlo Tresca Papers, 230.

${ }^{311}$ Carlo Tresca Papers, 231-232. 
importantly, protection. The three men in the little Italian grocery truck made it out of Itasca County with their lives, but not before the Itasca County Sheriff bid them bon voyage with "Remember forever that this place is not fit for you. When you come again I will kill you! Go and keep going!”312

Tresca's trip to Itasca County was harrowing, but his day was quickly going to go from bad to worse. As he arrived back in Hibbing, Tresca heard of the melee at the Mosonovich home and sensed trouble in the air. He went to Hibbing strike headquarters, the Finnish Workers Hall, and noticed that the building was "deserted, closed and dark." ${ }^{313}$ It did not take the veteran organizer long to put two and two together and knowing of the Governor's proclamation he feared the worst. As an article in the International Socialist Review about the Mosonovich ordeal concluded, "picketing was absolutely suppressed, and Finnish socialists were thrown out of their own halls and refused the right of lawful assembly." ${ }^{314}$ The Governor-inspired round-up was underway.

Tresca then made his way to strike headquarters in Virginia and found conditions on the streets, in the businesses, and at the Socialist Opera House—strike headquarters— much the same. Finding the city almost deserted, Tresca headed to the small home of Italian immigrant strikers where he was staying. He felt safe in this home as there were a number of his fellow countrymen armed with rifles ready to protect their anarchist Fellow Worker. Upon arriving in the home, Tresca inquired about fellow organizer Frank Little who had a seeming predisposition for getting himself into harrowing situations. Tresca's

\footnotetext{
${ }^{312}$ Carlo Tresca Papers, 231-232.

${ }^{313}$ Carlo Tresca Papers, 233.

${ }^{314}$ West, "The Mesaba Strike," 161.
} 
housemates notified him that Little had gone to his downtown Virginia hotel room for the night and was refusing to look for more secure lodgings. Tresca and his Italian bodyguards left to go speak with his Little in the hopes of convincing him to relocate. He was unable to convince Little to seek new lodgings, as Little cited the want of a good night's sleep as a reason to stay put. Tresca parted ways with his Italian bodyguards, asking only an American IWW organizer, James Gilday, to stay on. He then rented a room in the same hotel with Little. ${ }^{315}$

At about four o'clock in the morning of July 4, things got interesting for the Italian immigrant organizer. He heard a loud banging on his door, the shuffling of feet, and whispers. Tresca rose and went to the door, stepped onto a chair and peeked through the doorway's glass transom at a large group of men in the hotel's hallway outside his room. The mob of men in plain clothes, accompanied by one suited deputy sheriff, announced that they wanted to arrest Tresca. Tresca inquired about an arrest warrant to which someone in the mob replied, "We don't need no warrants for fellows like you." He was not willing to open the door to the mob, but a female hotel staff member pleaded with Tresca to give up and come out of the room. Speaking through the door Tresca quipped, "well, Madame, I never fail with ladies. If you tell me who is there, and tell me the truth, I will open the door." 316 She assured him that there were lawmen present. Slowly, Tresca opened the door, facing the waiting mob of nineteen men.

The mob took Tresca to the city jail where Sam Scarlett and Frank Little were already imprisoned. Tresca saw Little, who, according to Tresca, was in a strangely good

${ }^{315}$ Carlo Tresca Papers, 233-235.

${ }^{316}$ Carlo Tresca Papers, 235. 
mood, sarcastically quipping, "You see they did spoil my good sleep, those rascals." The IWW organizers were in the holding cells for a short time when they were escorted by armed men to a waiting train that consisted of one engine and one car. Inside the car, Tresca spied four men, "three of them handcuffed to each other by the wrists, while the fourth was lying on a bench badly wounded in the legs. All of them were without coats; their shirts were badly torn and bespattered with blood; the head of one was all bandaged." 317

Initially the train car carrying Tresca, Little, Scarlett, Gilday, and the four unknown passengers was silent as the armed guards, who outnumbered the strikers two to one, did not allow any talking, themselves remaining silent except to say, "be sure that you won't see Virginia any longer" to the eight wary passengers. As the train rolled through the northern Minnesota hinterland on its way to the city of Duluth, the order of silence began to lift and Tresca found out that the bloodied and bandaged riders were the men from the Mosonovich home. He wrote of the bloodied men, "these were the four men that we had found in the railway car. They were all being conveyed to Duluth to be imprisoned on a charge of murder in the first degree." Realizing that the car was exclusively carrying passengers charged with murder, Tresca sarcastically quipped, "as to Little, Gilday, Scarlett and myself, we also were charged with murder as accessories before the fact." He continued, "this is why we were in the car. We were being accused of

${ }^{317}$ Carlo Tresca Papers, 235-236. 
a murder that took place in our absence in a different town. We were being attached artificially to the murder case in order to eliminate us from the strike picture." 318

\section{Before concluding commentary on the plot to railroad (literally) the IWW}

organizers from the Iron Ranges, this dissertation must acknowledge that there is no documentary evidence to implicate the Governor, Sheriff Meining, or the mining companies in a premeditated order to shoot-up the Mosonovich home. It is absolutely possible that the events in Chicago Location were the sad outcome of a liquor raid gone horribly bad. However, even if the violence at the Mosonovich home was unintended, a case of escalating anger unfurled during a chaotic brawl, the prerequisite disposition for unintended fatal consequences was sealed by the Governor's June 30 proclamation. Burnquist's "telegram" to Meining made the violent deportation of IWW organizers, which the mining companies had wanted from the start of the strike, a certainty. His proclamation gave mining company managers and their hired thugs the opportunity to provoke a confrontation that would ensure the arrest of the IWW's leadership. And, arrest, deport, and incarcerate they did.

\footnotetext{
${ }^{318}$ Carlo Tresca Papers, 237. Of note, in his autobiography, written years after the fact, Tresca recalled the story he heard of the incident while on the train: "four deputy sheriffs had gone to the house of a striker by the name of Philip Masonovich with a warrant for the arrest of one of the boarders. The men of the law were very rough and they beat up Philip's wife. There were three Montenegrin workers boarding in the house. The fellows were former soldiers who had participated in many a war in the Balkans. They could not allow the deputy sheriffs to continue their dastardly acts. So they dashed against the four deputy sheriffs, took away their guns, killed one and wounded another. It was a real battle between deputy sheriffs and strikers, and they were all arrested." Tresca's account, written years after the fact and included in early drafts of his autobiography differed from the account of Militza Mosonovich, and other strikers' publications. Tresca was seeming to imply that the residents of the Mosonovich home were protecting themselves and got the upper hand on the sheriffs in the fracas, shooting them to save their own lives. He also mistakenly mentions that only one deputy died, and another deputy was wounded, leaving out the fact that while one deputy, Myron, did die the other "deputy" who was shot was in fact John Ladvalla a passerby sympathetic to the strike.
} 
While the IWW's leadership was in a Duluth jail, charged with first degree murder via a manufactured conspiracy, the strike found a way to survive the ravages of a stacked sociopolitical deck. Never mind that the real conspiracy that existed on the Ranges was the one between mining companies and Minnesota's Governor-the strike leaders and the Mosonoviches and their boarders were in serious trouble—each charged with a capital offense. An article in the International Socialist Review stated it best when summing up the situation, "placing the strike leaders on trial for murder was simply an effort to eliminate their influence and activities in the strike. It is a repetition of the old story of all the great industrial conflicts in this country, namely the prostitution of public authority to the whims, caprices and desires of "big business." ${ }^{319}$ Now, the looming question for the strikers and the IWW was if they could salvage the strike in the midst of great repression, an emboldened band of company thugs, and the loss of some of the IWW's most dynamic organizers.

${ }^{319}$ Christensen, "Invading Miner's Homes," 162. 


\section{Chapter 9: A Flame Extinguished?}

\section{Chapter Introduction: A Rhetorical Labor History}

The final chapter of the dissertation highlights the efforts to keep the strike afloat, while mining company managers and Progressives attempted to scuttle union efforts on the Ranges. Part labor history and part rhetorical analysis, this chapter chronicles the last days of the 1916 Strike. And, in a similar fashion to Chapter 7, this chapter turns to rhetorical analyses of the IWW's efforts to communicate with striking workers using multi-modal methods. Initially highlighting the oratory of Elizabeth Gurley Flynn, the chapter shifts to examine the changing rhetorical strategies of the union as they came to terms with the demise of the strike. Unlike Chapter 7, however, this chapter also provides rhetorical analyses of mining company and Progressive media in an attempt to chronicle the powerful forces pushing back against the IWW's effort to organize workers on the Ranges. Surprisingly, it was not the mining companies who offered the most skillfully delivered rhetoric against the IWW; rather, Progressive politician Victor L. Power and his adept oratory did the most damage to the IWW's ethos as a reputable labor union.

\section{The Struggle to Keep the Fire Lit}

The Governor's proclamation had an immediate effect on the strike as it jailed some of the IWW's most talented organizers and simultaneously demonstrated the power of the mining companies to influence people in high places. Now in the hands of St. Louis County's judicial system, Tresca, the other IWW organizers, and the Mosonoviches' trials began on July 21. The International Socialist Review wrote regarding the opening day of the trial in Duluth: "When the preliminary hearing of the strike leaders commenced before Judge Smallwood on July 21, 1916, the striking miners 
gave testimonial to the confidence that they had in their leaders and expressed the sentiment and spirit of the men on strike. The striking miners crowded the court room, corridors and halls of the municipal court at Duluth, and when the men under arrest, led by Carlo Tresca entered the court room, the men started a demonstration which lasted until the army of court bailiffs cleared the court room."320

While Duluth was humming with the intrigue of trials for political prisoners, momentum was lost on the Ranges as the IWW's rank-and-file was left to contemplate the jailings of well-known and highly regarded IWW members. The union's administration was consumed by attempting to free the talented, but overly prosecuted organizers. And, Tresca and the others in jail were in ominous circumstances. As the initial trials ended, however, several of the IWW organizers were released from custody. Others were bound over to face a St. Louis County grand jury. As one IWW publication commented on the situation, "on July 28 four of these [organizers] were dismissed, namely: Little, Gilday, Stark and Russell. The five others, Tresca, Scarlett, Schmidt, Ahlgren and Wessman were bound over to the Grand Jury for the August term of Court to answer the charge of actual participation in murder." ${ }^{321}$ While four IWW organizers were out and this was a small victory, the strike seemed to hinge on re-firing the passion of the IWW's rank-and-file, raising funds for a protracted strike, and bringing in new and equally talented organizers to accomplish both of the aforementioned goals.

The momentum lost by the IWW after the arrests did not go unnoticed by mine managers. Ireland wrote of the almost leaderless strikers, "last night the socialists held a

\footnotetext{
${ }^{320}$ Christensen, "Invading Miners' Homes," 162.

${ }^{321}$ Industrial Workers of the World, The Startling Story of the Minnesota Miners' Strike, 15. 
meeting in Nashwauk and 150 men came over from Keewatin to pack the meeting, but the leaders did not arrive as scheduled and whether the Sheriff stopped them enroute or what I do not know." Ireland linked the quelled union activity directly to the Governor's edict, "it is possible that a more determined effort will be made to start something in Nashwauk, but in view of the Governor's proclamation believe that the Sheriff of Itasca County will see the writing on the wall and stop it before it starts." ${ }^{322}$ Itasca County, and the lucrative Canisteo District mines, were a difficult prospect to organizers for the IWW. The entire county was tightly under the grip of very conservative iron ore and timber bosses and Tresca had literally been run out of Grand Rapids, the county seat. This tight grip on civil liberties pleased Ireland and during the chaos of St. Louis County's altercations with the strikers, Ireland found solace in Itasca County's seemingly corporative utopia, "the sheriff of Itasca County and Mr. Reifel [mine superintendent] and his police in Nashwauk have been dealing with the agitators pretty firmly, and as long as we can find men who are willing to work we will be able to keep going." 323 In an attempt to rescue the strike and the IWW, Bill Haywood sent the IWW's best rhetor to the Minnesota Ranges. Elizabeth Gurley Flynn stepped off a train and onto the violence-riddled Mesabi Iron Range in mid-July. She almost immediately captivated the IWW's rank-and-file as well as the region's presses. Traveling in a bread truck with

\footnotetext{
${ }^{322}$ James D. Ireland to M.A. Hanna \& Co. Agents, "Personal Correspondence," July 1, 1916, Butler Brothers and M.A. Hanna Company Records Collection, Iron Range Research Center, Chisholm, Minnesota, Box MSS 158, Folder NE, Lake Superior-General—Labor Lake Superior Situation 1916, 8370 .

${ }^{323}$ James D. Ireland to M.A. Hanna \& Co., Agents, "Business Correspondence, "July 3, 1916, , Butler Brothers and M.A. Hanna Company Records Collection, Iron Range Research Center, Chisholm, Minnesota, Box MSS 158, Folder NE, Lake Superior-General_Labor Lake Superior Situation 1916, 8370.
} 
Italian chauffeurs (perhaps the same traveling companions as Tresca), Gurley Flynn zipped up and down the Mesabi delivering passionate speeches in the defense of striking workers and the political prisoners held in Duluth. Gurley Flynn was welcomed by some, reviled by others. Her mission on the Ranges was to rescue the 1916 Strike and it was going to be a difficult one. She had been to the Mesabi Range during the 1907 Strike, acting as an organizer during that industrial conflict. During the strike she found love, marrying fellow organizer J.A. Jones. Though the two later parted ways, Minnesota was familiar territory. But her task and travels amidst the long distances and violent exchanges of the 1916 Strike wore on her greatly as she recounted in her autobiography: All that summer the strike dragged out a dogged existence. We raced up and down the Range from one end to the other in an old bakery truck driven by a couple of young Italian strikers, who often forgot we were not bread and bounced us unmercifully over the unpaved rocky roads. The deputies came to know the truck and took pot shots at us, so we had to stop using it, much to our relief. There were about 14 towns from one end [of the Mesabi Range] to the other, which we covered. Several times the strikers marched the length of the Range, holding meetings in each town. On one occasion some towns shut off the drinking water while we were there. ${ }^{324}$

Equally distressing was the situation of her fellow organizers who were locked up in Duluth. Gurley Flynn was most concerned with the condition of Tresca, as she and the Italian anarchist had developed an affinity for one another and were actively engaged in

${ }^{324}$ Quoted in Karni, "Elizabeth Gurley Flynn...," 5. 
an ongoing romantic relationship. Gurley Flynn was worried that at best Tresca would be in jail for a long time and at worst be executed for capital murder. She visited him in the St. Louis County jail in Duluth often. Tresca, in turn, was concerned with Gurley Flynn's safety on the Ranges, reasoning that the violence and lawlessness of company police and the deputy sheriffs would not be confined to the IWW's male organizers. After Gurley Flynn had left the Ranges on a fundraising tour, Tresca wrote mutual friend Mary Heaton Vorse from his Duluth jail cell, "I am very glad she is out. I feel now very much relefe [sic]. When she was here I can’t sleep. My poor girl! Cheer her up, Mary dearest, please!" 325

Despite Tresca's concerns for her safety, Gurley Flynn's tough demeanor, dynamic oratory, and amiable public persona insulated her from the worst of the Ranges' assaults. Just twenty-five at the time, Gurley Flynn's youth and obvious middle-class appurtenances juxtaposed those of the other IWW organizers, while transfixing mixedclass audiences as she delivered blistering and impassioned oratory against the Mesabi Range's industrial backdrop. Her personal background and style of dress was perhaps Gurley Flynn's most significant attribute as an organizer and contributed to her unique lexis as an orator for the revolutionary IWW: she simply did not look the part. Often donning long flowing dresses with neatly pressed white shirts, while her jet black hair was wrapped in a tight bun sitting under a fancy hat, she made no bones about being an outsider who supported an oppressed immigrant working-class. This played into her ethos, which was starkly different from the IWW's other organizers. She was a woman,

\footnotetext{
${ }^{325}$ Nunzio Pernicone, Carlo Tresca: Portrait of a Rebel, (Oakland, Cali.: AK Press, 2010), 90-91. Quote is from an originally quote in Pernicone, 91.
} 
yes, but she also had something that the likes of Tresca, Scarlett, and Little did not. Male IWW organizers on the Ranges' were somewhat ruff-and-tumble and could be intimately linked with the Ranges' hardscrabble workers. Gurley Flynn did not look or act the part. She was born and formally educated in the United States with a strong middle-class upbringing, but she was a champion of working-class immigrants. There was no reason for her to care about the plight of the Ranges' immigrant working-class families, but she did. The passionate oratory from someone who had no immediate class connection with immigrant workers meant something to the outside world and her fiery middle-class advocacy of immigrant laborers made it publicly palatable for others of the same class background to share her sentiments.

The local press picked up upon this distinction. While she looked the part of a middle-class "lady," her tone and tenor while speaking was anything but middle-class. It was inflammatory. It was impassioned. It was revolutionary and it was powerful. Mary Heaton Vorse commented on Flynn's oratory during the strike, “when Elizabeth spoke, the excitement of the strikers became a visible thing. She stood up there, young, with her Irish blue eyes, her face magnolia white, her cloud of black hair...it was though a spurt of flame had gone through the audience, something stirring and powerful, a feeling which made the liberation of people possible." 326 The Mesabi Ore newspaper, friendly to Progressives like Victor L. Power, but antithetical to the IWW wrote glowingly of Gurley Flynn, "we heard a corker of a speech." The newspaper commented further:

${ }^{326}$ Mary Heaton Vorse as quoted in Lammpa, Minnesota's Iron Country, 215. 
Miss Flynn has been pictured by the corporation newspapers as a fiery anarchist that preached bloodshed and murder throughout the land, as a means for adjusting the difference between capital and labor, but we have found her nothing of the kind...she is a woman with a big heart, and it is filled to overflowing with sympathy for humanity... we could only wish that more preachers, more newspapermen, more business men, more people generally, could hear this woman as she gives her message of hope to the lowly man who has nothing but his labor to sell, who daily sees the cost of living advancing while his wage remains at a standstill...the big employing corporations here and everywhere have a gripping fear of this women, and we have always wondered why. It is because of her honesty, her sincerity, her stirling [sic] ability and genius of leadership. She is not a ranter, but an orator, and her force carries the conviction of her honesty." 327

While area newspapers of the Progressive and kept press maligned the IWW's "foreign" agitators like Tresca and Schmidt, Gurley Flynn was greeted with acceptance by some of these English-language newspapers and even with enthusiasm by others. The Strikers' News picked up on this conversion announcing in one article, "Elizabeth Gurley Flynn Makes Good Impression," continuing, “one newspaper man on the Iron Range has decided that all the I.W.W. organizers are not bloodthirsty savages and dehorned devils since hearing Elizabeth Gurley Flynn speak." ${ }^{328}$ It was Gurley Flynn’s speaking-style, her middle-class ethos, and well-appointed lexis that captivated middle-class audiences

${ }^{327}$ Strikers' News, August 4, 1916.

${ }^{328}$ Ibid. 
along with the IWW's already sympathetic working-class audience. This middle-class audience was the educated, equality-seeking, literate, and personally wealthy demographic that the IWW sought to tap into for monetary help in continuing the strike. The IWW needed funds to keep the strike afloat, but also to wage a defense for their embattled and imprisoned organizers. Gurley Flynn's fiery rhetoric on the Mesabi Range was an attempt to fire-up striking workers in a wearying labor conflict, but also was an attempt to broadcast the plight of striking workers to an expanded, monied, and hopefully sympathetic middle-class audience.

Still, though, many in the kept press treated Flynn as a pariah for her beliefs. The Virginia Enterprise reported that at one mass meeting in the Socialist Opera House after a long and arduous strikers march through Virginia, Flynn dismissively stated that it "has been a wonderful day." The Enterprise, however, retorted that, "she said nothing of the sufferings of the innocent children...who went along because their parents said they must. She said nothing of the failure of the parade as a means of adding recruits to the IWW." ${ }^{229}$ Clearly not everyone was enamored with E.G. Flynn.

As the strike ground down in the hot, humid days of a mid-summer Minnesota, money became the primary concern. In the same manner that Elizabeth Gurley Flynn was dispatched to the Ranges in an attempt to resuscitate the strike, the IWW was attempting to produce media offerings that would bring the events of the strike nationwide exposure, which would hopefully induce that national audience to give freely to the IWW. It was at this time, after the arrest and imprisonment of Tresca and others that the IWW

\footnotetext{
${ }^{329}$ Quote taken from Michael Karni, "Elizabeth Gurley Flynn and the Mesabi Strike of 1916," in Range History, Vol. 5, No. 4, (Chisholm, Minn.: Iron Range Research Center, 1981), 4.
} 
commissioned a rhetorical work that sought to elicit support for the flagging efforts surrounding the strike. Titled "The Startling Story of the Minnesota Miners' Strike on the Mesaba Range 1916," this pamphlet was published by the Minnesota Iron Range Strikers' Defense Committee, which was located in New York City. Not mincing words or intentions, the front cover of the media offering noted that the treatise was "SOLD FOR THE BENEFIT OF THE STRIKERS.” In the sixteen page narrative of strike events, the IWW sought to make a final argument for the moral imperative and eventual success of the strike. Targeted toward an audience who lived away from the Minnesota Ranges, the thin, portable pamphlet-style "story" was designed with a dual purpose in mind: to raise funds for the strike and get the jailed organizers out of lock up. ${ }^{330}$

Using the three rhetorical appeals in concert, the pamphlet's impassioned language, statistics, and well-appointed writing style sought to tell the workers' side of the strike from the strike's inception to the then current situation on the Iron Ranges. Covering everything from "Where is the Mesaba Range and Who are the Strikers" to "The Reign of Terror on the Mesaba Range," the pamphlet was a cogently organized tract complete with sub-headings and a table of contents. The work's intended audience was likely the same audience that was receptive to Elizabeth Gurley Flynn's rhetoric: educated and middle-class with leisure time, money to give to causes, and reformist tendencies. Unlike media materials distributed at the local level on the Iron Ranges, which advocated industrial revolution such as the Strikers' News, this pamphlet used verbiage and technical jargon designed to create sympathy for striking workers and their

\footnotetext{
${ }^{330}$ Industrial Workers of the World, The Startling Story of the Minnesota Miners' Strike, 1-2. 
chosen representative- the IWW. The pamphlet included well-reasoned arguments infused with legal lingo such as the use of the term "expiate" to describe the situation of jailed Fellow Workers. In another legalese example, "The Startling Story" included a summation of the loss of First Amendment rights during the strike: "the primary civic rights of men were de facto suspended. The right of free speech and free assemblage were practically nullified. All the jails of the range were filled and are now filled to overflowing with strikers and organizers, mostly arrested without warrants and on absurd pretenses." This technical jargon was intermixed with long, flowing descriptions of solidarity amidst poverty and great odds, "desperation, suffering, poverty, over-workthose are the causes of the revolt, those are the prime factors that welded the different nationalities together and drove them to action." An additional example of a skillfullycrafted rhetorical appeal to middle-class reformist audiences came when the author or authors of the pamphlet addressed income inequality arguing that, "the wives of miners who are producing this wealth from mother earth are breadless and see their children starve. Mrs. Gary, the wife of the president of the Steel Trust, is distributing shares of Steel Trust stock as favors and souvenirs to her guests at her gorgeous dinners." ${ }^{331}$ The clever acknowledgement of audience contained in this pamphlet again emphasized the IWW's adroit use of rhetoric as the pamphlet seemed to be courting readers who sought common ground with strikers on the basis of appeals to the best aspects of human nature and not didactic allusions to outright class struggle. Because of the pamphlet's intended audience, revolutionary industrial unionism was not on the menu; rather, the plight of

${ }^{331}$ Industrial Workers of the World, The Startling Story of the Minnesota Miners' Strike, 1, 8, and 15. 319 
starving children and wives living in ramshackle hovels were chosen as emotional appeals better suited to a reformist, middle-class audience.

\section{Oppositional Rhetoric from the Steel Trust}

Of course, the IWW was not the only group producing rhetorical appeals. Mrs. Gary's husband was fighting back against the IWW's rhetorical salvos mainly through the mining company influenced presses. The battle for the hearts and minds of the general public was not lost on mining company administrators, especially in Minnesota's Progressive, reformist political climate. In the same way that the IWW effectively used multi-media messaging, mining company managers sought to portray their side of the strike's story. Based in the idea that massive accumulation of wealth by individuals benefitted a paternalistic, American society founded on the laissez-faire economic principles, mining managers and executives portrayed the IWW as a "foreign," terrorprone, bomb throwing organization of miscreants bent on the destruction of civil society and personal property. The common line was that the IWW was stirring up trouble in peaceable, functional communities that were not in need of outside assistance. The image mining companies sought to advance through their media offerings regarding the IWW was that of violent outside interloper. 


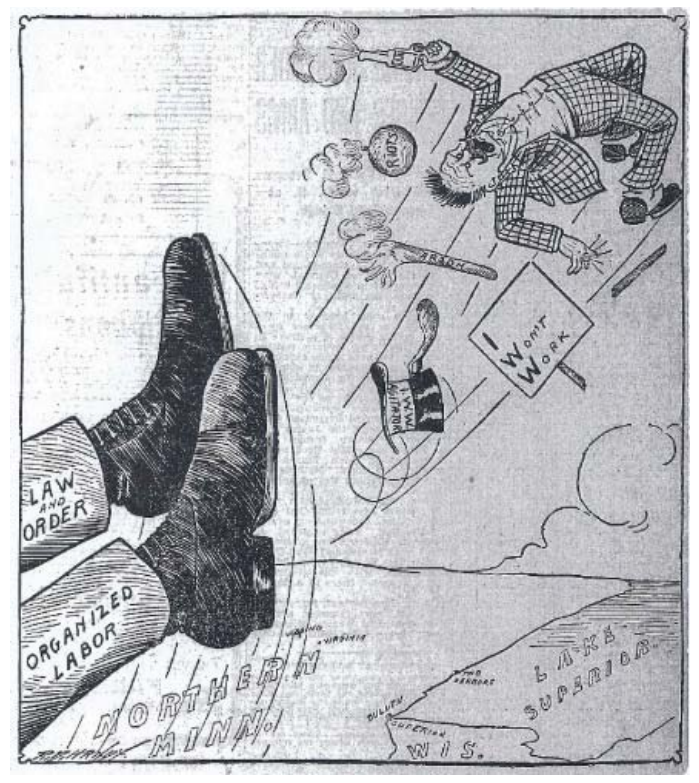

Figure 9.1--Cartoon from the "kept press" identifying IWW organizers as violence-prone revolutionaries

One particular cartoon from a local newspaper summed this perspective especially well. A rhetorical analysis of the above cartoon, demonstrates that pathos appeals were the main substance of mining company influenced arguments against the Wobblies. The IWW organizer, the figure being kicked by the dual boots of "Law and Order" and "Organized Labor," was dressed in a cheap three-piece suit, once adorned with a since toppled top hat that read "I.W.W. Organizer." To symbolize the hostile behavior associated with IWW organizers the cartoon's artist drew four implements of violence: a pistol, which the organizer was shooting off; a lit bomb labeled "riot"; a smoking stick identified as "arson"; and a picket sign with the slogan "I Won't Work," a common, derisive snub at the power of strikes to facilitate economic change. The cartoon's general message to a mostly middle-class audience was one that appealed to this segment of the public's basic sense of security by advancing the notion that the IWW was an imminent 
threat to their safety. This was a powerful portrayal of the stereotype that mining companies wanted to advance regarding the IWW and the emotive effect of the cartoon's violence presupposed that the IWW was up to no good in northern Minnesota.

Also wrapped in the cartoon's symbolism was the idea that the IWW was at odds with law and order, as well as reputable labor organizations such as the American Federation of Labor (AFL). The "Organized Labor" boot carried the message that the IWW was somehow a slipshod, unorganized collection of labor fakirs. Painting the IWW as being so radical as to stand outside the confines of their established union brothers and sisters was an attempt to distance skilled labor, represented by unions in the AFL, from unskilled labor represented by the IWW-in essence a metaphorical wedge between working-class populations. There were also ethnic and racial undertones, as well as class distinctions, in this symbolism surrounding the message that "organized" labor was at odds with the IWW and the "riff-raff" the Wobblies were attempting to organize. The sotermed "Organized Labor" caricature was wearing a fashionable boot that was in lockstep, or kick, with "Law and Order." Additionally, at this time so-termed reputable organized labor was home to ascending middle-class skilled workers who were not prone to direct action or strikes in efforts to better their lives. Through connotation the cartoon seemed to be intending that American or Anglo-European skilled laborers understood civil society, while members of the IWW were unskilled foreign laborers duped by outside agitators and neglectful of American customs and traditions. This was a common refrain in English-language newspapers during the early $20^{\text {th }}$ century, founded in a Galtonian pseudo-science ethos that provided a morality for the exploitation of unskilled, ethnically inferior workers. This type of duplicitous depiction of the division of labor, 
skilled versus unskilled and American versus foreigner, was a strategy employed by mining companies to divide the workforce at the point of production and in society as well. Sadly, this was a powerful tool in breaking strikes. ${ }^{332}$

In confrontations between the "foreign" troublemakers and American protectors of property and life, company-kept newspapers were quick to sensationalize the supposed violence of IWW-affiliated strikers. Newspapers, like one local Hibbing rag, only had to include the last names of the combatants in a quest to delineate the Americans from the foreigners. In one such ethnically charged clash, the exploits of the Teller brothers took center stage in the desperate fight to ward off the seemingly Mongol-like hordes of striking members of the IWW. In an article titled, "MINE GUARDS ARE STABBED; TWO CLUBBED," the author sensationalized the conflict by using emotional appeals to bolster the efforts of the apple pie powered, morally upstanding All-American Teller brothers writing, "Brothers, Fighting Side by Side, Fall Beneath Strikers' Knives." Later in the article it becomes clear that the area was in the full ravages of a type of class war and that the two brothers had been bested in an all-out, no-holds-barred street brawl, “Martin Teller, chief of the Oliver Iron Mining Company’s special deputies is the most seriously wounded. In the battle he was stabbed four times; twice in the back, once in the thigh, and once between the ribs. His brother Charles, who was fighting at his side, suffered a deep cut on the side of the neck." While Martin and Charles had nice American sounding names, the newspaper was certain to point out that the "three strikers

\footnotetext{
${ }^{332}$ For a depiction of how mining companies treated "foreign" labor organizers in the 1913-14 Michigan Copper Strike see Kaunonen and Goings, Community in Conflict: A Working-class History of the 1913-14 Michigan Copper Strike and Italian Hall Tragedy.
} 
locked up are Steve Dronjack, Eli Manovich and Raphael Pett. All of them are battered up by the billies of the officers." 333

Lost in the article is the fact that the Teller boys were identified as members of the Oliver's "special deputies" and not St. Louis County deputy sheriffs or local Hibbing police officers. The Tellers had no legally-sanctioned powers to arrest striking workers on public property. In fact, they were just as culpable for the violent melee as those who were arrested. As the article continued, "the trouble started shortly after 6 o'clock on Third Avenue and North Street [in Hibbing] when Marcus Clark attempted to reach the mine entrance through a crowd of about 200 strikers on picket duty. He was edged to and fro and several blows landed on his head. Village police came to his rescue, and Martin Teller and his brother Charles, started to aid them." Perhaps noticing that Martin and Charles Teller were in a precarious legal situation the article shifted the sensationalism with ethos appeals, name dropping a who's who of Hibbing authorities, "M.J. West, superintendent of the Oliver Iron Mining Company in Hibbing district rushed to the scene the minute news of the clash reached him and remained until all signs of trouble had disappeared." Another Hibbing celebrity appeared on the scene "about 20 minutes after the fight" as "Chief of Police William Dwyer came up with the patrol wagon, walked boldly into the crowd of 200 strikers and picked out and arrested Steve Dronjack, alleged to have been the man who did the stabbing." Though Dronjack was supposedly the

${ }^{333}$ Victor L. Power Papers, “Scrapbook: Newspaper Clippings,” Vol. 1. 
culprit, the newspaper was forced to acknowledge that "he was accused of using the knife, although none was found on him when he was searched." 334

If the sensationalism of the actual event was not enough, the Hibbing rag went a step further and covered Martin Teller's stay in the hospital. This was perhaps the most ludicrous of the skewed journalism as the article recounted that, "Teller's anxiety was for his wife, who had left him yesterday to go to Foster City, Michigan. 'Don't let her know,' he instructed." While the angels swirled around Martin Teller blowing horns of absolution, justice, and mercy in a Hibbing hospital, the newspaper got busy asserting blame for the fracas. Again attempting to craft pathos appeals portraying the IWW as violence-prone outsiders, the article's author wrote, "George Andreytchine, leader of the strikers, was in the crowd, and shouted that the men had done nothing to warrant a clubbing and arrest. 'If they start, we'll finish it,' he shouted." 335 Yet another article on a different skirmish got more to the point. One wounded warrior who had survived the ravages of another recklessly portrayed "foreign" horde was identified as a hero with seemingly presidential connotations, "John Adams, an American miner at the Sellers Mine was threatened with bodily violence by a group of striking pickets as he approached the mine entrance this morning." ${ }^{336}$ It was clear that the strikers were under assault by the company-influenced English-language press, and class, ethnicity, and assimilation were central components of the argument against the IWW.

\footnotetext{
${ }^{334}$ Ibid.

${ }^{335}$ Ibid.

${ }^{336}$ Ibid.
} 


\section{Victor L. Power and the Progressive Pushback}

Making matters worse for the IWW was the attitude of Progressive politicians such as Victor L. Power. A supposed advocate and friend of the working-class, Power's relationship with organized labor was conditional and certainly did not extend to the IWW. While mining company rhetoric was pointed and critical of the IWW and its rankand-file, Power's skilled oratory, adept rhetorical strategies, and keen political acumen were like a well-positioned punch in the face of Wobbly organizing efforts.

Power saw the deportation of the IWW's organizers as a chance to swing the Ranges' workers away from the IWW and toward the AFL. A champion of the conservative union ideology of the AFL, Power began a campaign to convince multiple audiences of the potential efficacy of an AFL alignment with striking workers, possibly through the United Mine Workers of America (UMWA) union. With the IWW's organizers mostly out of the way, with the notable exception of Gurley Flynn, Power and the Ranges' other Progressive mayors attempted to arbitrate the strike and swing a triumphant blow for Progressive, reformist ideology.

Newspaper articles covered the arbitration efforts, touting Power's ethos and condemning the IWW's alleged violence. Power's own scrapbooks and journals give a chronicle of the Range Strike Committee and their efforts to end the strike. From Power's journal, "July 7, Meeting Range Strike Committee, Virginia," and a week later on "Friday, July 14, Meeting Range representatives of Municipalities." Power took place front and center at the meetings and newspaper articles recounted his efforts at these "peace meetings," "there was another meeting of some range officials and politicians here tonight with Mayor Victor L. Power presiding...the conferees stated that Hibbing, 
Virginia, Aurora, Biwabik, Kinney, Buhl, Keewatin and Chisholm were the communities represented." Another clipped article in Power's scrapbook noted that "Mayor Power had this to say about the meeting tonight: 'The purpose of the meeting was to make an effort to bring mining companies and strikers together for a compromise so the men would get back to work." "337

Amidst the chaos and violence of the strike, Power seemed to be doing the work of a saint, but his saintly work perhaps concealed a more pointed purpose. In his position as arbiter of the strike and Progressive voice of the Iron Ranges, Power had gained real political power and he used this cachet to bring the AFL's state convention to Hibbing right in the midst of the dog days of the strike. His journal recounted that on "Sunday, July 16, State Federation of Labor convenes at Hibbing" and that on "Monday, July 17, Victor L. Power made address before State Federation of Labor, parade, etc.” Another article in the scrapbook began to shed light on Power's true reason for inviting the Minnesota labor conference to Hibbing, "[Power] stated that his main purpose in asking the convention to come to Hibbing was to bring about an organization of workers in that part of the state... he said the State Federation of Labor had been invited to Hibbing to give the plain people of the village an idea of its standing, character and power, and concluded by declaring his conviction that it was the proper body to organized the workers in the range country." 338 In short, it appeared that Power wanted to be leading the strike and sought to instill the AFL as the representative of striking workers.

\footnotetext{
${ }^{337}$ Victor L. Power Papers, “Scrapbook: Newspaper Clippings,” Vols. 1 and 2. ${ }^{338}$ Ibid.
} 
In Power, the IWW had a skilled rhetorical adversary. With a much vaunted college education, legal degree, and a lawyer's gift for gab, Power thrilled at the state labor convention delivering blistering attacks against the mining companies' greed and the IWW's ineptitude. Referring to the Minnesota State Federation of Labor as a "respectable organization," Power dissected the shortcomings of the IWW by highlighting the ethos of the AFL-linked state labor federation. A newspaper article in Power's scrapbook emphasized the oratory delivered to the labor organization, "'You,' said Mayor Power to the convention, 'are a respectable organization, you have prestige and you alone as an organization can do real good for the workingmen's cause.' Mr. Power urged that the American Federation of Labor take steps to organize the workmen of the mines and his recommendation will be considered at a special session of the convention this afternoon." Power's advocacy of the AFL went beyond speeches from the bully pulpit. Tucked into the pages of his journal between July 20 and July 21 was a business card which read, "W.R. Fairley, International Organizer, U.M.W. of A., Pratt City, Alabama. Washington D.C. Address-Stag Hotel, $9^{\text {th }}$ Street, N.W." ${ }^{339}$ It seems as though Power had moved beyond hosting AFL state conventions and had become an agent provocateur for the AFL's largest mining industry union-the UMWA.

This was unwelcome news for the IWW's flagging efforts during the 1916 Strike. It meant that opposition to the IWW was now coming from three sides: mining companies, Progressives, and the largest and most powerful mining union in the United States. In his advocacy of the UMWA, Power finally began an open attack on the IWW.

${ }^{339}$ Ibid. 
In one blistering speech delivered at the state labor conference Power unleashed a vitriolic assault on the Wobblies attacking their credibility as a labor organization, while attempting to highlight his own ethos as an informed champion of the working-class and alternative to the Wobblies adversarial attitudes toward mining company graft and greed: With labor in the mines unorganized, it is the helpless prey of such vultures of the industrial world as the I.W.W. In the last twelve years there have been three especial periods of abundant prosperity on the iron ranges - three times when the demand for iron ore has been particularly pressing, and when the mines have been rushed to capacity and when profits for the mine owners and prosperity for the ranges seemed about to flood the high water mark. In each and every instance the offscourings of organized labor descended upon the iron ranges, seized the opportunity to inflame the miners, incited violence of all kinds, stopped the wave of prosperity in mid-tide and rolled it back, bled the miners of their savings and robbed them of their means of livelihood. ${ }^{340}$

Unsurprisingly, the Range newspapers, who were wooed by Power's skillful communication style, accepted and openly advocated Power's premise: peaceful labor conditions in an AFL organized Iron Range. One newspaper article clipped and saved in Power's scrapbook opined, "'Unless there is an organization of the workers in the mines by a reputable labor organization, history will continue to repeat itself,' stated Mayor Power. His timely suggestion, which goes straight to the root of the Minnesota iron ranges' greatest difficulty, opens up a wide field of usefulness to the Minnesota State

${ }^{340}$ Ibid. 
Federation of Labor and if the Hibbing meeting shall be the beginning of the solution of this problem the coming of the convention to Hibbing will be the greatest blessing that has ever been vouchsafed Hibbing." 341

While publicly attacking the IWW, Power was simultaneously attending the trials of Tresca and others in Duluth, receiving calls from IWW organizer Joseph Ettor, and also holding personal meetings with Elizabeth Gurley Flynn. ${ }^{342}$ Tracing Power's trajectory of allegiances during the strike is difficult. He was a self-styled champion of the working man who opened the way in the early days of the strike for the IWW to organize in Hibbing. Later, however, he became a harsh vocal critic of the Wobblies and openly advocated for the AFL, while secretly contacting a UMWA organizer to facilitate that union's organization of the Ranges' mines. Power was an active man and this activity did not go unnoticed by mining companies' management. A Sunday, August 6, article preserved in Power's scrapbook read, "Hibbing Banks are Refusing Payment on Village Orders for Amounts of Large Size—cashier Egge of Merchants' and Miners' Band States that expenditures by Power Administration are exceeding the amount agreed upon last November between Mayor and W.J. West, Representing Oliver Iron Mining Company-In-debtedness of Village now more than a million dollars, says Cashier Newcomb of First National."343

Just as the Oliver and the Independents had grown tired of dealing with the IWW, it also tired of Power's political maneuverings. The Steel Trust was pushing back against

\footnotetext{
341 Ibid.

342 Ibid.

343 Ibid.
} 
the Progressive politician and were moving to shut off Hibbing's finances to discipline Power's government, claiming that Power had mismanaged municipal funds, while steering the city into vast amounts of debt. Power was in the political fight of his life and his strong rhetorical skills temporarily checkmated the financial wizardry of the Steel Trust. He straddled political death for some time, but remained Hibbing's mayor for nine years, attempted a run at a United States Congressional seat (but lost), and then retired into political anonymity. He was, however, beloved on the Iron Ranges. It is a testament to his rhetorical savvy and political acumen that among the social spaces named for mining company bosses such as Olcott Park in Virginia, Greenway high school, and the company town of Coleraine, named after Oliver manager Thomas F. Cole, there is a Vic Power Park in the heart of Hibbing. ${ }^{344}$

Thus, as Power was playing politics on the Range, perhaps attempting to salvage the vestiges of the 1916 Strike for later organizing activity partial to the UMWA, the last gasps of IWW organization were occurring. Late July found a federal government agency, the Federal Department of Labor, conducting an assessment of the strike, but even this investigation into the strike was not without its intrigue. Power, of course, was right in the middle of it all. The Department of Labor's investigators were H. Davies and W.R. Fairley—the same W.R. Fairly who had left his UMWA organizer's card with Power in mid-July. Though outwardly tasked with an impartial evaluation of the strike, Fairley was likely there to assess conditions for a restructuring of the strike and Power

\footnotetext{
344 Jack Lynch, Hibbing Daily Tribune, December 29, 2008, accessed at http://www.hibbingmn.com/news/years_of_yore/article_a2a85a5c-e918-5d54-95ee-47da3438790a.html, on November 15, 2014.
} 
was more than happy to aid in this effort. A July 27 entry in Power's journal noted that he returned from the "Tresca, et. al. trials in Duluth at 11 PM" and a newspaper clipping below the entry informed that "Strike Conciliators Start Work at Once_-Visit the Chisholm Strike District, Await the return of Mayor Power who is expected back this evening...both conciliators [Fairley and Davies] refused to talk of any length on questions pertaining to the strike, other than that the investigation would be fair and open to all sides and that a thorough survey of the conditions existing would be made." 345

On Friday, July 28, Power met officially with the federal investigators in his office at 10 a.m., but also went with them to his lake home and farm at 5 p.m. ${ }^{346}$ The intentions of the federal investigation of the strike were not really fooling anyone. The IWW knew it was political maneuvering, Power understood that it was a chance to court Fairley and the UMWA, and the mining companies, well they were suspicious of the investigation from the very start as an article in the company-influenced Duluth News Tribune indicated, “[Federal Government] Report Misrepresents Strike to Help I.W.W.Duluth Officials Assert Falsity of Statements in Document of Industrial Relations Commission-Allegations Absurd." ${ }^{347}$ With the government report having little, if any, effect on the strike, the IWW was in the proverbial wilderness and looking for a way out.

\section{The Fire Dies Out}

Imprisonment of its organizers, closing of labor halls, thwarting of sympathy strikes on Duluth and Superior docks, and the "railroading" of prominent organizers were

\footnotetext{
345 Victor L. Power Papers, "Journal Entries."

346 Ibid.

${ }^{347}$ Duluth News Tribune, August 2, 1916.
} 
all obstacles the IWW had overcome during the strike. Elizabeth Gurley Flynn had stepped in admirably in an attempt to resuscitate the strike, but in many ways she was attempting to fan the flames of discontent in an ashed over landscape. Minnesota's Iron Ranges had been on fire with the passion and power of a defining clash between organized labor and capital, but the flames had dwindled and were about to extinguish. The jailings and legal defense funds for Tresca, Schmidt, and others, competition with Progressives for working-class allegiances, and infighting between Bill Haywood and the IWW's organizers in the field all coalesced to make August a bad month for the IWW on Minnesota's Iron Ranges.

Through a very organized network of spies the mining companies were able to keep tabs on the IWW's management of the strike. Thanks to the company spies, mine managers were able to find out that the IWW was being very discretionary about funding a strikers' benefit account. These funds, typically bolstered by additional assessments or voluntary giving by union members, worked to sustain not only the pocketbooks of striking workers, but also the resolve of families affected by the strike. Strike benefits for prolonged labor-management confrontations demonstrated to strikers that the union, in this case the Wobblies, could take care of mineworkers and their families just as well as the "company." It appeared from the work of labor spies that the IWW was either reticent to devote funds to the fledgling labor actions on the Iron Ranges or was struggling to catch up in collecting assessments for the strike. Regardless, James D. Ireland, from his post as the General Manager of the Virginia Iron Ore Company wrote, "the I.W.W. has not as yet distributed any of their strike funds to the men, altho they promised married men $\$ 8.00$ a week, but the point is, I do not think the I.W.W. has got the money." Ireland 333 
surmised that the promised strikers' benefit funds were in fact only a bluff meant to bring the mining companies to the bargaining table. He was hopeful that strikers would make serious requests for the funds and that these requests would "explode the bubble, for the I.W.W. leaders do not want to distribute any strike funds... and their excuse now is that they cannot distribute strike funds until all the underground mines on the Mesaba [sic] are closed." 348

The simple fact was that the IWW had not closed down all the mines on the Mesabi, and they had barely penetrated the mines on the Vermilion and Cuyuna Ranges. While the strike had begun in early June, the Strikers' News was only reporting of strike activities on the Cuyuna Range in mid-August and activity on the Vermilion Range in early September. A Friday, August 18, article in the Strikers' News proclaimed that the "WHOLE CUYUNA RANGE IS NOW TIED UP," reporting that "the miners of Ironton, Crosby and Woodrow are idle...700 of them have thus far joined the I.W.W., and it is said that they are coming in faster every day." But, mining company officials were by now well versed in quelling the strike and the same article reported that "John Perich, Austrian organizer who was sent to Crosby from the Mesaba Range, has been arrested, together with four other strikers." 349 The September 1, issue of the Strikers' News let readers know that the strike had spread to the Vermilion Range, but the strike actions were confined to one mine in Winton. "On Monday, August $8^{\text {th }}$, a delegate representing 330 miners of Winton... appeared before the Central Strike Committee in Virginia to request that organizers be sent to that section," reported the Strikers' News. The IWW

\footnotetext{
${ }^{348}$ James D. Ireland to Virginia Ore Mining Company, “Typed Personal Correspondence,” June 28, 1916. ${ }^{349}$ Strikers' News, August 18, 1916.
} 
sent John Pancner, a roving organizer, and Charles Jacobson, President of the Virginia branch to found a local. ${ }^{350}$ The Vermilion Range's lone local was late to the party, because on September 22, the strike on the Ranges was officially called off.

The Strikers' News heralded the official proclamation from the Central Strike Committee in Virginia writing:

In rebellion against intolerable conditions we came out on strike, entirely unorganized, without funds, experience or even acquaintance with one another. We were compelled to rely on the labor movement throughout the country for relief to provide bread for our wives and babies. Hundreds of our ranks as well as our organizers and speakers were arrested, and the latter group are now in jail facing a charge of murder...we have fought all summer and have grappled with the mighty octopus the Steel Trust with all the power we possessed. But we feel it would be unwise to prolong our battle through the terrible cold of a Minnesota winter. ${ }^{351}$

Now, the difficult process of picking up the pieces was about to become a reality. A defense fund for the jailed organizers was begun in earnest and headquartered in Virginia. James Gilday was in charge of the operations and Elizabeth Gurley Flynn began a whirlwind speaking tour in hopes of raising money, "Elizabeth Gurley Flynn will start on a speaking tour for the purpose of raising funds for the defense. The first meetings will be held on the range and in Itasca County and she will then proceed through the Twin

\footnotetext{
350 Strikers' News, September 1, 1916.
}

351 Strikers' News, September 22, 1916. 
Cities to Chicago, Omaha, etc." ${ }^{352}$ While Flynn roamed the countryside hoping to scare up funds for the strikers' defense fund, it was a group Italian immigrant anarchists, and not the IWW, who actually came to Tresca's aid. There was acute infighting occurring within the IWW's leadership regarding the disposition of the jailed Fellow Workers and organizers like Joe Ettor had left the organization claiming that Haywood had centralized the union too much. Gurley Flynn was also on the outs with Haywood because he refused money for the defense fund and in doing so her partner, Tresca. In the long run, the aid was unnecessary as the trials against Tresca, the other IWW organizers, and the Mosonoviches and their boarders came to a quick, but contentious conclusion. In December 1916, Tresca and the other defendants reached plea deals with the St. Louis County prosecutor in which Tresca, the other IWW organizers, and Melitza Mosonovich and Orlandich would be set free, while the other persons in the Mosonovich boarding house charged with murder would plead guilty to first degree manslaughter and serve only one year of a three year sentence. The Italian anarchist was a free man, but the acrimony between Tresca, Flynn, and Haywood would occasion Tresca's leaving the IWW, never to return. ${ }^{353}$

The IWW tried to put a militant face on the ending of strike activities, but the disappointment of the 1916 strike was unavoidable. In addition to the local and state repression and pressure on the IWW, the 1916 strike and the IWW lost momentum in September due to the nascent era of "Red" investigations and charges of subversion

\footnotetext{
${ }^{352}$ Ibid.

${ }^{353}$ Pernicone, Carlo Tresca: Portrait of a Rebel, 91-93.
} 
related to the onset of World War I. ${ }^{354}$ The IWW's confrontation with American capitalism, the Steel Trust, and the Ranges' Independent mines came at an especially difficult and dangerous time for labor unions: the eve of American entry in World War I. Radical labor unions and their members were especially ripe for scrutiny as the rhetoric for involvement in the "war to end all wars" began to crescendo. As a theoretically world-wide organization, committed to the solidarity of all workers, the IWW's stance on militarism included a harsh critique of war as a profit making endeavor sponsored by nations, corporations, and bosses to further exploit the working class. To combat such proletarian narratives Loyalty Leagues and pro-industry citizens groups organized to support capitalism, militarism, nationalism, and defend against anti-American sentiment. ${ }^{355}$ The repressive walls of a nation at war were closing in and the 1916 Strike and the IWW became a casualty of the capitalists' world war.

In a final analysis of the 1916 Strike, it would be naïve to find the bloodshed of the labor conflict the fault of the mining companies only, but for all the misleading, company-sponsored rhetoric that charged the IWW with intimidation, outrage, and violence; it must be pointed out that the IWW never called upon the use of institutionalized violence once during the 1916 Strike. The Wobblies were a group committed to direct action and the IWW was most likely looking for a proverbial fight only. However, it is evident that when the IWW staged a march or protest, the mining companies did nothing to alleviate tensions. Instead, the mining companies elevated the

\footnotetext{
${ }^{354}$ Pinola, "Labor and Politics," 37.

355 "Doings of the Month," in International Socialist Review, Chicago: Charles H. Kerr Publishing Co., August 1916, 71-72.
} 
tensions and in many instances provoked conflict. Like prior strikes in the Lake Superior basin, the massive 1916 Strike ultimately ended with the mining companies breaking the strike. Defiant to the end, the IWW brought an end to strike activities by declaring that "with the calling off of the Mesabi Range Iron Ore Miners Strike in the various range towns, and similar action on the Vermilion and Cuyuna Ranges, IWW leaders here today described their defeat as a temporary truce with the mine operators." 356

${ }^{356}$ The Duluth News Tribune, September 18, 1916. 


\section{Conclusion: Rising from the Ashes}

In a final rendering of the labor conflict that enveloped Minnesota's Iron Ranges in 1916 the epic battle between organized labor and the Steel Trust and Independents had been at best a stalemate according to the IWW and at worst a loss according to the mining companies' perspective. What followed, however, was the IWW's darkest hour. Mired in the United States government's well-orchestrated repression of the World War I era's anti-syndicalist, anti-immigrant, and anti-labor laws and losing converts to the successful 1917 Red October Revolution by the Bolsheviks, which resulted in the eventual establishment of the Soviet Union, the Wobblies were again trumped by the dual pressures of a like-minded group that espoused working-class interests and the tyranny of a governmental campaign to persecute and prosecute the IWW out of the nation's boundaries and consciousness.

As World War I raged and the Bolsheviks wrestled Mother Russia from its imperialist hold, the campaign to rid the IWW from representing industrial workers was on as the federal government began prosecuting, jailing, and even deporting members of the IWW from the United States in earnest in 1917. This most infamous of these actions was known as the IWW 166 Trials. These trials decimated the IWW's ranks. Of the original 166 defendants, "ninety-three men were sentenced after the I.W.W. trial at Chicago, on August 30,1918, to a total of 788 years imprisonment and to pay a fine of $\$ 2,788,000$." This abuse of human rights was documented by a prisoner who was incarcerated in Leavenworth Penitentiary as a result of the trials. Addressing a typed letter to "Woodrow Wilson, President," the political prisoner documented the repression meted out against the IWW, "since the early part of 1917 the I.W.W. has been subjected 
to a persecution without parallel. Headquarters, offices and even homes of members, were raided; our letter-files, records, and office equipment seized, and members arrested by the hundreds." Equally insidious was the federal government's attempts to stymie an effective defense against prosecution during the trials, "our defense was hammered by raids on our union offices. The Post Office Department stopped our papers; thousands of letters, many of them registered, dealing solely with our legal defense, were seized; hundreds of letters were delivered six months to a year after mailing. Furthermore, during the Chicago trial many of our witnesses were intimidated by detectives and Army Intelligence Department officers."357

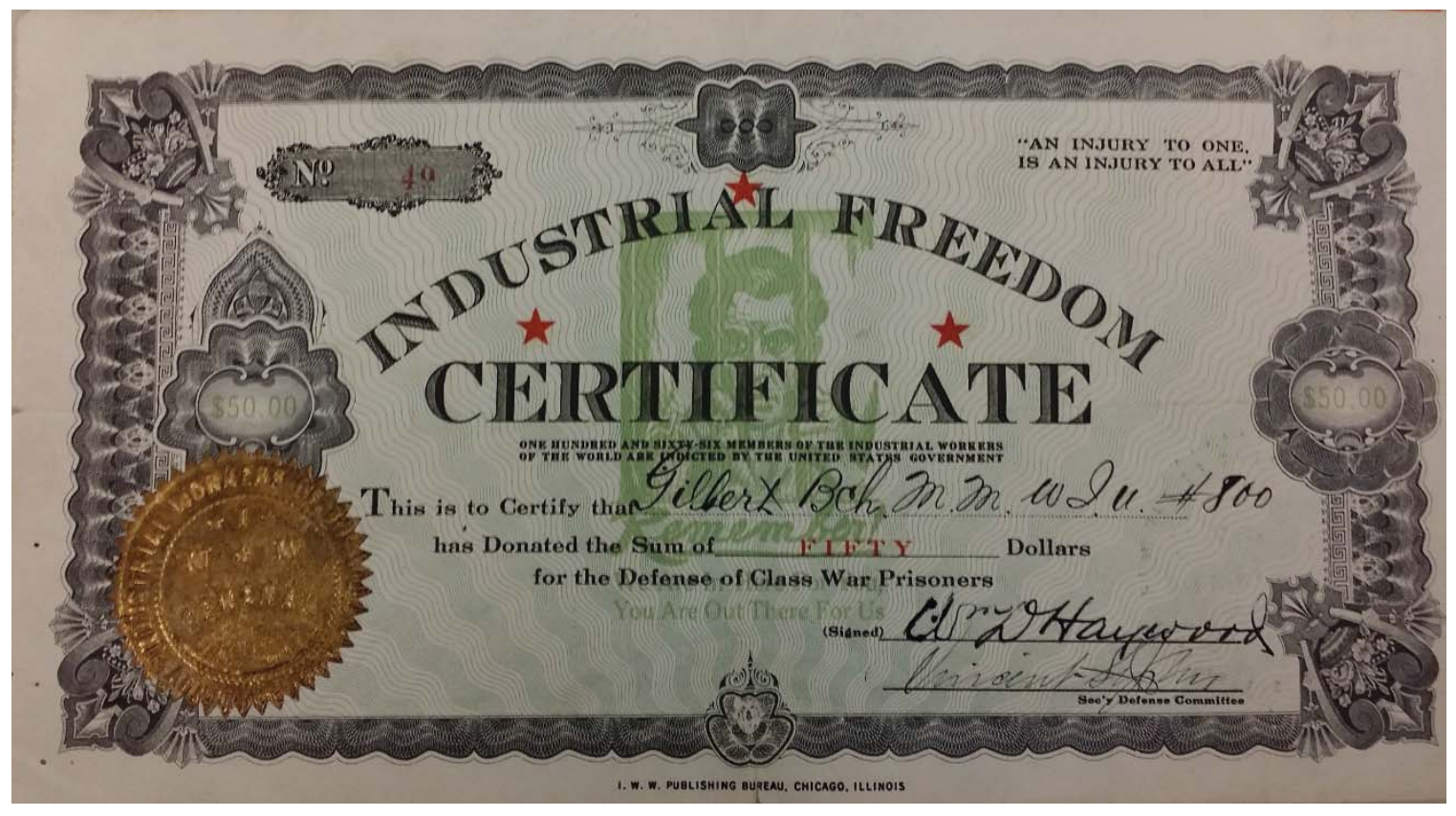

Figure Conclusion 1-Industrial Freedom Certificate of $\$ 50.00$ contribution to the IWW's 166 trial defense fund-Immigration History Research Center

\footnotetext{
${ }^{357}$ Leavenworth Prisoners to President Woodrow Wilson, "Personal Communication," March 9, 1919, The Elizabeth Gurley Flynn Papers, Italian American Collection, Immigration History Research Center, University of Minnesota, Minneapolis, Minnesota.
} 
The IWW, headed by Bill Haywood (who was himself a defendant) and Vincent St. John, attempted to immediately organize a defense fund for the imperiled Fellow Workers by soliciting $\$ 50.00$ bonds from IWW locals and in return giving the locals a handsomely printed, embossed, and officially sealed "Industrial Freedom Certificate." Other efforts at workers' defense funds came after the conclusion of the trials and from organizations partial to radical unionism, but not affiliated with the endangered IWW. After her detachment from the IWW, Elizabeth Gurley Flynn headed one such organization known as the Workers' Defense Union, which was headquartered in New York City. With her rhetorical flair intact, Gurly Flynn and the Workers' Defense Union distributed letters in 1919 seeking donations and solidarity from other radical workingclass groups:

Dear Comrades: We have decided that this first May Day after the last five years of blood and tears should not only be a celebration of the rising tide of proletarian dictatorship in Europe, but a nation-wide protest against the imprisoning and imprisonment of Socialists, I.W.W.'s and all other champions of labor and liberty.

There are nearly two thousand political prisoners in the United States to-day. Many of them are well-known and well-loved, others are obscure and almost forgotten. We must speak and act at once and in a determined manner for all those who pay with their freedom for their devotion to their class. ${ }^{358}$

\footnotetext{
${ }^{358}$ Elizabeth Gurley Flynn, Secretary of the Workers' Defense Fund, "Letter to Comrades," March 25, 1919, The Elizabeth Gurley Flynn Papers, Italian American Collection, Immigration History Research Center, University of Minnesota, Minneapolis, Minnesota.
} 
The mass trials of Wobblies was just once such way to curb the IWW's influence. The federal government also began deporting Wobblies from the United States altogether. Defense funds were began for these people as well. In a letter sent to Gurley Flynn, Caroline A. Lowe, an attorney in Chicago wrote to members and friends of organized labor on March 19, 1919, that there were "twenty-one men imprisoned on Ellis Island [who] are awaiting deportation. Scores, if may hundreds, more are being arrested, held for a farcical hearing before prejudiced Government [immigration] inspectors, and condemned to life-long exile from the United States." She went on to state that "these men are being deported solely because of membership and activity in a labor union-the Industrial Workers of the World."359

Iron Range locals and Finnish immigrant working-class organizations gave willingly to these defense fund efforts. As seen in the certificate above, the Gilbert Branch of the Metal and Machinery Workers Industrial Union No. 800 provided $\$ 50.00$ to the "Defense of Class War Prisoners" who had been "indicted by the United States Government." Finnish immigrant organizations affiliated with the IWW gave to the Workers' Defense Union efforts of Gurley Flynn as the "Finnish Branch of the IWW" and the "Metal and Machinery Workers Industrial Union, No. 300, Finnish Branch," proudly were listed as supporters of the cause. ${ }^{360}$ Regardless, the harsh repression of the IWW continued, somewhat unabated even after the Red Scare era of the 1920s, though

\footnotetext{
${ }^{359}$ Caroline A. Lowe to Elizabeth Gurley Flynn, “Organizational Communication Letter,” March 20, 1919, The Elizabeth Gurley Flynn Papers, Italian American Collection, Immigration History Research Center, University of Minnesota, Minneapolis, Minnesota.

${ }^{360}$ Elizabeth Gurley Flynn, Secretary of the Workers' Defense Fund, “Letter to Comrades," March 25, 1919.
} 
Minnesota's Finnish immigrant population remained stark bulwarks of the movement as evidenced by Industrialisti's (Finnish-language publication of the IWW in Duluth, Minnesota) long publishing history. It is of significance to note that the doors of the Industrialisti did not close until the 1970s. And, as the dissertation pointed out in one of its Solidarity-inspired History Vignettes, the IWW has been undergoing a resurgence organizing service industry workers in present-day Minneapolis. The Minnesota IWW branches have even resurrected the Work Peoples College, though it has moved to Minneapolis. These contemporary resurgences demonstrate that even after such harsh repression, IWW sentiment and collective labor action rose from the ashes of the 1916 Strike.

Equally significant was the rising of union and political sentiment on the Iron Ranges after the 1916 Strike. As Iron Range historian Pamela A. Brunfelt wrote in her essay, "Political Culture in Microcosm: Minnesota's Iron Range," "by the 1920s the people of the Iron Range had begun to assert some control over their communities. Many of the immigrants had educated themselves about the American political system, completed the naturalization process, and were poised to become fully engaged in the political process." In the efforts to build such a political identity the interethnic rivalries, which were a subject of great attention while organizing the 1916 Strike, seemed to fade into the once divided social landscape. The children of immigrant workers became fullfledged Americans, married inter-ethnically, and were enfranchised with the vote and a political voice. Many of these Americans found a home in Minnesota's Farmer-Labor 
Party, which eventually joined the Democratic Party in 1944 to form Minnesota's unique Democratic Farmer-Labor Party or the commonly termed DFL. ${ }^{361}$

By the Depression Era, the rumored to be Communist-influenced Steel Workers Organizing Committee (SWOC) had made in-roads into the corporately secured and labor spy laced Iron Ranges. In the work place, many Iron Range workers actively supported and joined what would become the United Steel Workers of America (USW) in 1942, a union of unions representing workers in the steel industry and a founding member of the progressively-intentioned Congress of Industrial Organizations (CIO). The CIO would later join the American Federation of Labor in 1955. Much of the CIO's revolutionary ideology was abandoned in the 1950's McCarthy Era, but the radical beginnings of the industrial union were forged in early labor struggles such as the 1916 Strike. Today, the USW is the largest industrial union in North America with over 800,000 members. As the USW web-site acknowledges, "the seeds of this great union were planted in the late 1800 s by our fathers and mothers, our grandparents, our greatgrandparents and so on. They were seeds of commitment, solidarity and a common interest to fight for better conditions for working men and women everywhere."362

Thus, it was clear that although the IWW had been rebuffed in their attempts to organize the Minnesota Iron Ranges, the legacy of the 1916 Strike paved the way for future union efforts in northern Minnesota. Sam Swanson, a former Wobbly and the

\footnotetext{
${ }^{361}$ Pamela A. Brunfelt, "Political Culture in Microcosm: Minnesota's Iron Range," accessed at http://www.minnesotahumanities.org/resources/political\%20culture\%20in\%20microcosm.pdf, on November 15, 2014.

${ }^{362}$ United Steel Workers, "Our History," in Our Union, accessed at, http://www.usw.org/union/history, on December 8, 2014.
} 
seasonal wanderer in search of employment, finally set down roots and took up work as a labor organizer with the Steelworkers in the Minnesota iron mines. He too recognized the importance of past labor struggles in the push to organize Minnesota's mines in the Depression Era:

On the part of the immigrant mine workers, most of whom had emigrated from Europe to this area of America seeking peace and freedom from oppression and who could not cope with the language of their adopted country, the lack of trade union knowledge and practice was one of the pitfalls of organizational attempts through the early years of industry. But the first-generation Americans, sons of fathers who worked in the mines, were instilled with the backbone and determination of their fathers, and they were the sparks which ignited the Iron Range in 1937 when they formed the first local union of the C.I.O. in Ely, today's Local 1664, United Steel Workers of America. ${ }^{363}$

The ties between the early struggles to organize the Ranges and the Depression Era's successful drive to unionize were many, but one tangible link existed in particular - the Finn Hall as a social space of discontent. As Swanson recalled, "in the spring [of 1937], the first open meeting of miners interested in the Congress of Industrial Organizations was held in the old Ely Workers' Hall," which was formerly a Finn Hall. In another case on the Cuyuna Range people from the South Slavic Federation borrowed the local Finnish Workers' Hall to plan for their own Croatian Miners' Orchestra Hall. ${ }^{364}$

\footnotetext{
${ }^{363}$ Samuel Swanson Collection, "Sam Swanson Radio Message...".

${ }^{364}$ Brunfelt, "Political Culture in Microcosm," 4.
} 
One of the SWOC's most influential and gifted organizers was Matti Halberg, the son of a Finnish immigrant striker who was blacklisted by the mining companies after a 1905 or 1907 strike on the Mesabi Iron Range. Halberg's family had been supporters of the IWW, but shifted allegiances to the communist movement sometime after the Red October Revolution. After his organizing experiences on the Iron Ranges and with the SWOC in the 1937 Little Steel Strike in Youngstown, Ohio, steel mills, Halberg went on to become Gus Hall, General Secretary of the Communist Party-United States of America in 1959. Hall's class-consciousness and eventual rise in the ranks of the CP-USA can be directly attributed to his family's active participation in the labor struggles of Minnesota's Iron Ranges in the early $20^{\text {th }}$ century. ${ }^{365}$ The early labor struggles of the $20^{\text {th }}$ century had a lasting impact on the Ranges' peoples and places and that impression of working-class identity was enduring. To this day, northern Minnesota is union country and this powerful empathy with working-class identity and culture can be traced directly back to the struggles of the 1916 Strike.

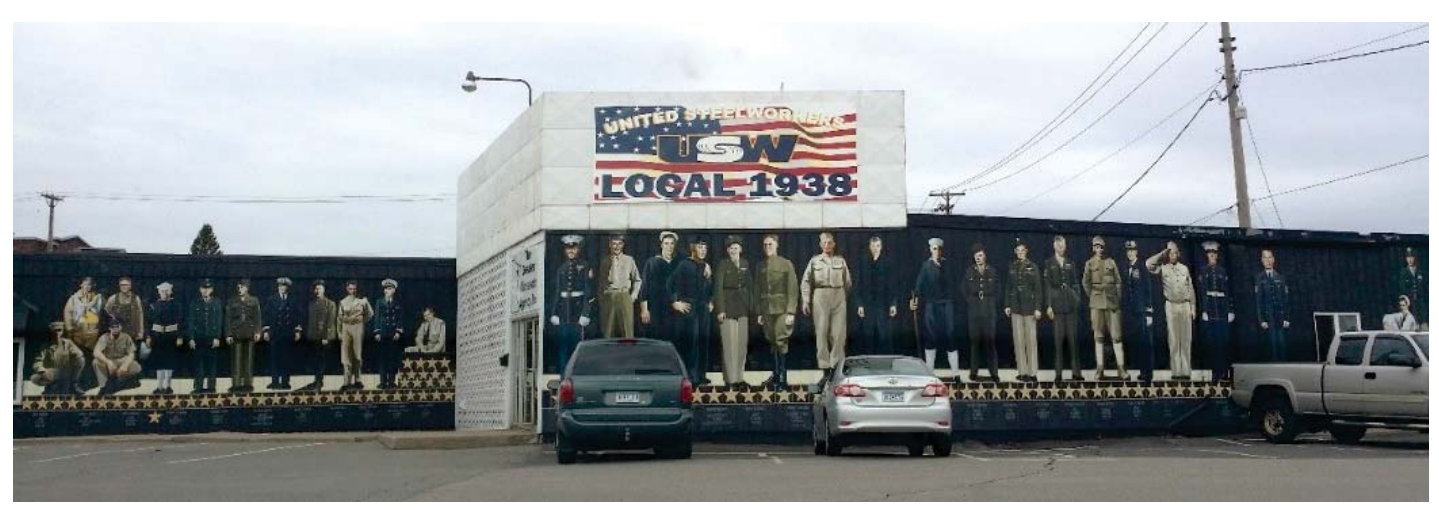

Figure Conclusion 2-Contemporary image of USW Local 1938 mural located at union headquarters in downtown Virginia--image taken by Gary Kaunonen

\footnotetext{
${ }^{365}$ Gary Kaunonen, “Arvo Halberg/Gus Hall: The Making of an American Communist," unpublished senior honors thesis, Minnesota State University-Mankato, Spring Semester 2003. 
Virginia, Minnesota's USWs' Local No. 1938 is an exceptional example of this perspective. Representing Virginia's iron ore workers since the Depression Era, the USW Local remains an active participant in the struggle for economic justice. And, less than one block from USW Local No. 1938's headquarters is the former Virginia Socialist Opera House, which is now home to another union, the Carpenters and Joiners Local 606 and a co-operative credit union. Unbeknownst to many is the central role this grand edifice played in one of Minnesota's most significant labor-management confrontations. The building is nothing less than a national landmark and deserves to be treated as such. The Opera House's grand interior was gutted in the late 1950s, however. A Minnesota Historical Society entry in the MNOpedia quoted a January 30, 1958, article in the Mesabi Daily News, which recounted the transformation of the one-time cultural center for the voices of discontent during the 1916 Strike:

"Remodeling Plans for Old Opera House Will Leave Only Memories of Range's Colorful Cultural Center of Yesterday.” The article explained that the city's Socialist Opera House was being renovated as a retail and office building by its owners, the local chapter of the United Brotherhood of Carpenters and Joiners, which had bought it in 1955 for $\$ 125,000$. "The gilt has worn away and oncegleaming white boxes and balcony sections are discolored," the article read. "Up in the rafters, above the stage rigging, is lashed a wooden boat which once sailed a water-tank in the stage floor." 366

\footnotetext{
${ }^{366}$ Kate Roberts, "Socialist Opera House, Virginia," in MNOpedia, accessed at, http://www.mnopedia.org/structure/socialist-opera-house-virginia, on December 1, 2014. 


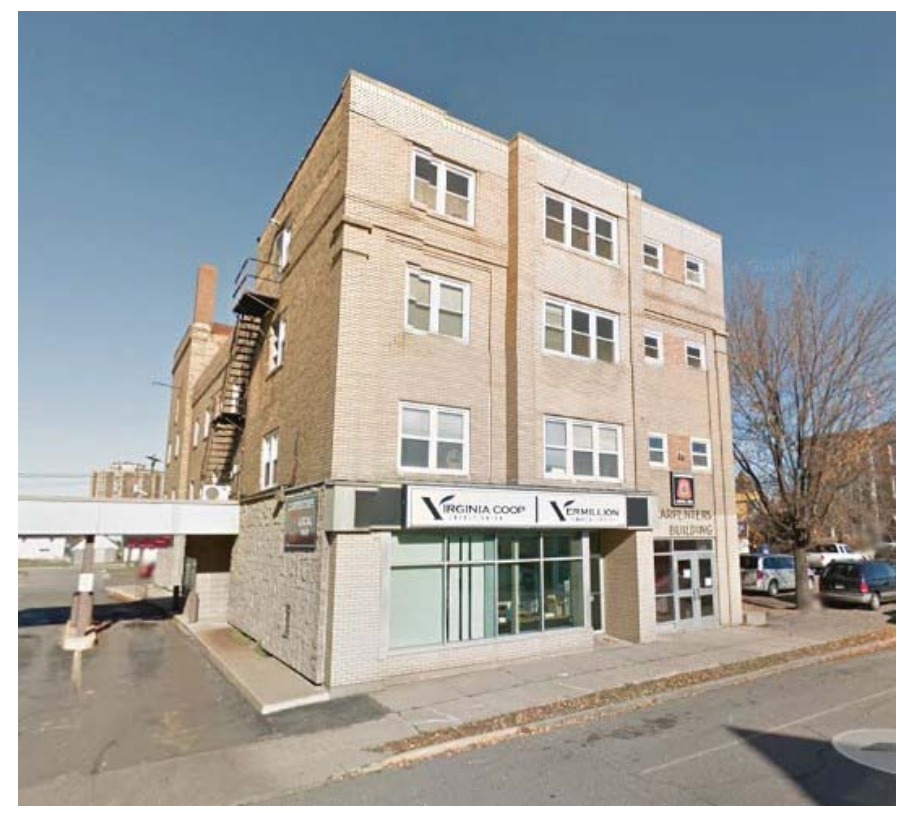

Figure Conclusion 3-Contemporary image of the former Socialist Opera House in Virginia, Minnesota-Google Street View

Thus, Solidarity-inspired History has a story of its own on the Minnesota Iron Ranges. Though recollections of the 1916 Strike and the repression, arrests, and deaths of striking workers is a distant memory, the Ranges' working-class ethos has maintained a strong connection with those who fought and died during this epic clash between labor and management. The memorialization of the 1916 Strike through regional labor activism is essentially a localized endeavor, however. The struggle to give a more comprehensive voice to the historical actors of the 1916 Strike is ongoing.

This struggle to restore voice punctuates this work's primary argument—having a history is a basic human right and this dissertation is an example of how to accomplish such a goal. This central perspective is a type of critical history that embraces the use of primary, temporally appropriate sources to speak for underrepresented historical actors. Methodologically, the dissertation is unique because it maintains an interdisciplinary approach to the study of the historical past. This multi-perspective inquiry paints a vivid 
and nuanced image of the efforts to organize the Iron Ranges' immigrant laboring masses. Such multiple perspectives of inquiry blend historical research of documents, media offerings, landscape studies, image analysis, oral history, cultural history, material culture studies, and rhetorical analysis of primary materials to distill the essence of the lived experience of the Ranges' working-class populations prior to and during the 1916 Strike. While these perspectives are the primary modes of inquiry for this dissertation, other compatible fields can include but are not limited to: archaeology, geology, gender studies, engineering history, historic preservation studies, literature studies, and political science.

Through such a critical, interdisciplinary perspective the dissertation offers a more comprehensive interpretation of the 1916 Strike, while placing the voices of those working-class individuals and organizations who lived the events at the center of the historical narrative. In this manner, each methodological "tool" provides a discreet pathway to examining the whole lived experience of striking workers. The utilization of landscape to situate the Iron Ranges in a spatial and temporal context provided the dissertation with background; examination of primary texts in multiple languages highlighted previously unexplored "written" histories of the strike and the development of their identity as class-conscious American workers; oral histories, such as those done with Veda Ponikvard and Fred Torma gave an intimate picture of life on Minnesota's Iron Ranges; studying the rhetorical strategies of the IWW provided a specific understanding of the IWW's skillful use of rhetoric during the strike; and cultural history and material culture studies afforded an understanding of the symbolic activities, physical structures, and tangible items of discontent produced by supporters of the IWW. 
The significance of utilizing material culture as a part of rhetorical analyses of the IWW during the strike is underscored by the plight of the IWW 166. As the letter from the imprisoned Wobbly in Leavenworth indicated, the raids on IWW offices and homes destroyed "our letter-files, records, and our office equipment was seized." Where these primary source documents went is anybody's guess. The United States government succeeded in obliterating the official voice of the IWW through the eradication of these primary documents in oppressive raids, but the material culture of the IWW and its mostly immigrant rank-and-file: the labor halls, the industrial landscapes, and the songbooks have endured in many cases to give scholars, historians, and present day activists an understanding of the immigrant voices who called the IWW their own union. An excellent example of this preservation is the contemporary Socialist Opera House building, which survived the ravages of time to serve as a home to a contemporary union local and tangible memorial to the labor unrest of the 1916 Strike.

Therefore, it is clear that the efforts to chronicle and preserve the voices of striking workers on Minnesota's Iron Ranges in the early $20^{\text {th }}$ century were fraught with difficulties. In most cases, these workers were not afforded a voice in the development of their own history. In many ways this led to a dislocation of their story from the historic record, but it also disarticulated their plight from current social actors and activists. To remedy this wrong, this dissertation introduced the framework/practice perspective of Solidarity-inspired History $(\mathrm{SiH})$, which proffered the opportunity for dislocated historical actors to be posthumously re-engaged with contemporary populations. This dissertation offers, proposes, and suggests that today's activists, social justice advocates, and perhaps most importantly, union members, embrace the opportunity to become 350 
engaged with and learn from the past in order to continue the fight for economic and social justice with a more complete understanding of the historical contexts that delivered us to our present circumstances.

Solidarity-inspired History is, then, a variant of critical history that seeks to provoke positive, progressive social change. In developing this critical perspective, a definition of what critical history should be was offered. Stating that critical historians had a responsibility to develop the posthumous agency, empowerment, and voice of past historical actors was only an identification of the goal. Advocating, enabling, researching, and writing the history is the action-based imperative that gives such a critical perspective merit. $\mathrm{SiH}$ is an action-based historical perspective. The dissertation went on to argue that critical history and the critical historian should enable those who have been marginalized or purposefully left out of the historic record to find their "voice" through the work of contemporary scholars and that such a working-class voice could be found in the historical record via compelling primary sources, interdisciplinary research strategies, and methodological flexibility.

Grounded in such a critical perspective, $\mathrm{SiH}$ must examine every aspect of historical agency and carefully determine whether such agency has been effectively asserted, needs to be reasserted, or perhaps even crafted anew in a discussion of the past. Additionally, this socially engaged historical practice should also examine whether this agency has been appropriately conveyed; is a narrative accurate, and if it is not, critical historians should advocate for a corrective to the past scholarship. In many ways, critical history is unabashedly about "voice." The establishment, reassertion, or reinterpretation 
of such voices can have serious consequences and $\mathrm{SiH}$ bears a responsibility to provide ethical and moral treatments of the past.

Finally, and fulfilling the aims of $\mathrm{SiH}$, this work provided commentary on how the plight of the 1916 strikers, as historical actors, can advise, inform, and teach contemporary social actors in the ongoing fight for social justice through SiH Vignettes. This analysis on how the past can inform the present and change the future is a key development and extension in the "history from below" project E.P. Thompson started well over forty years ago. SiH's examination of historical actors' whole lived experience is also an extension of Herbert Gutman's pioneering project in American labor history, but $\mathrm{SiH}$ does not leave history in the past. Rather, it contends that history can inform the present and guide, perhaps even empower, future social actors. The struggle to positively transform the past is not held in a vacuum sealed off from each generation. The fight for dignity, justice, and solidarity in 1916 is essentially the same struggle we encounter today. The social actors may have changed, but the struggle remains the same. Immigrant rights, workplace democracy, social justice, and the re-humanization of workers in a global, transnationally situated economy concern contemporary populations in the same manner as they did mineworkers in 1916 Minnesota. As George Santayana's well-worn words might echo, the more we as a society believe that we have escaped the injustices of our past, the more we are condemned to repeat those transgressions in the future. This dissertation is a recollection of such an exploitative past, but holds promise that the lessons of such a past can help to empower contemporary actors to positively change and shape the future into a more democratic and equitable landscape. 


\section{Bibliography}

\section{Primary Sources}

Aristotle. Rhetoric-Books I-III. Translated by W. Rhys Roberts. Accessed at http://classics.mit.edu/Aristotle/rhetoric.html, on November 1, 2014.

“Austrian, The" to Charles Trezona. "Worker's Correspondence," January 8, 1908. Oliver Iron Mining Company Collection, Minnesota Historical Society, St. Paul, Minnesota, Box 2.

Bullard, Polly. "Personal Correspondence." In Bring Warm Clothes: Letters and Photos from Minnesota’s Past, compiled by Peg Meier. Minneapolis, Minn.: Star and Tribune Company, 1981.

Butler Brothers and M.A. Hanna Company Records Collection. Iron Range Research Center, Chisholm, Minnesota. Box MSS 158, Folder NE, Lake SuperiorGeneral-Labor Lake Superior Situation 1916, 8370.

Carlo Tresca Papers, The. "Autobiography," 1879-1943. (Microfilm). Italian American Collection, Immigration History Research Center, University of Minnesota.

Chamoream, P.F. to Charles Trezona. "Business Correspondence,” July 24, 1907. Materials Relating to the Oliver Iron Mining Company, Minnesota Historical Society, St. Paul, Minnesota.

Chaplin, Ralph. "Solidarity Forever." In I.W.W. Songs to Fan the Flames of Discontent, Joe Hill Memorial Edition. Cleveland, Ohio: I.W.W. Publishing Bureau, n.d. Christensen, Otto. “Invading Miner's Homes.” In International Socialist Review, Volume 17. Chicago: Charles H. Kerr Publishing Co., 1916. 
City of Eveleth. Municipal Records Ledger. "Register of All Persons Committed to the Lockup at Eveleth, Minn., 1909-1915.” Iron Range Research Center, Chisholm, Minnesota, Box 16.

. Municipal Court Records Ledger. "Register of Criminal Actions," September-

October 1904 to May-June 1906. Iron Range Research Center, Chisholm, Minnesota, Box 16.

Dragosich Family Papers. "Croatian Fraternal Union of America.” Iron Range Research Center, Chisholm, Minnesota.

Elizabeth Gurley Flynn Papers, The. Italian American Collection. Immigration History Research Center, University of Minnesota, Minneapolis, Minnesota.

E.M. to G.C.S. "Labor: Working Conditions, 1885-1928," February 10, 1885. James S. Steel Collection, Minnesota Historical Society, St. Paul, Minnesota, Box 1, Folder 50.

“Emmi." "IWW:n Marssi.” In Raatajain Lauluja. Duluth, Minn.: Workers Socialist Publishing Company, n.d.

Flynn, Elizabeth Gurley. Sabotage: The Conscious Withdrawal of the Workers' Industrial Efficiency, October 1916. Accessed at, http://www.iww.org/culture/library/sabotage, March 10, 2010.

Greenway, John C. to George W. Morgan. “Business Correspondence,” May 22, 1916. Oliver Iron Mining Company Papers, Correspondence and Miscellaneous Papers, 1901-29, Box 1.

Greenway, John C. to Oliver Mining Company Labor Agent. "Business 
Correspondence," June 8, 1908. James S. Steel Collection, Minnesota Historical Society, St. Paul, Minnesota, Box 2, Folder 6.

. "Business Correspondence," March 11, 1907. James S. Steel Collection, Minnesota Historical Society, St. Paul, Minnesota, Box 2, Folder 6.

Greenway John C. to William J. Olcott. "Business Correspondence," October 27, 1906. James S. Steel Collection, Minnesota Historical Society, St. Paul, Minnesota, Box 2, Folder 6.

Hawkings, M.S. to Mr. Pentecost Mitchell, n.d. "Living Conditions 2, 1908-1919." James S. Steel Collection, Minnesota Historical Society, St. Paul, Minnesota, Box 1, Folder 140. . .n.d., "Living Conditions 2, 1908-1919." James S. Steel Collection, Minnesota Historical Society, St. Paul, Minnesota, Box 1, Folder 140.

Hearding J.H. to Pentecost Mitchell. "Business Correspondence," May 20, 1908. James S. Steel Collection, Minnesota Historical Society, St. Paul, Minnesota, Box 1, Folder 140.

. "Business Correspondence," May 27, 1908. James S. Steel Collection, Minnesota Historical Society, St. Paul, Minnesota, Box 1, Folder 140. . "Business Correspondence," June 3, 1908. James S. Steel Collection, Minnesota Historical Society, St. Paul, Minnesota, Box 1, Folder 140. Hill, Joe. "The Good Old Wooden Shoe." In I.W.W. Songs: To Fan the Flames of Discontent, Joe Hill Memorial Edition. Cleveland, Ohio: I.W.W. Publishing Bureau, no date.

Industrial Workers of the World. What is the I.W.W. Preamble? A Dialogue, $4^{\text {th }}$ printing. 355 
Chicago: Department of Education, Agricultural Workers Industrial Union, 1923. . An Economic Interpretation of the Job. Chicago: Department of

Education, Agricultural Workers Industrial Union, 1922. Accessed at:

https://www.marxists.org/history/usa/unions/iww/1922/economic.html, May 1, 2014.

. The Startling Story of the Minnesota Miners' Strike on the Mesaba Range 1916.

New York: The Minnesota Iron Range Strikers’ Defense Committee, 1916. . IWW Songs: To Fan the Flames of Discontent, Joe Hill Memorial Edition.

Cleveland, Ohio: I.W.W. Publishing Bureau, no date.

. Teollisuus-Unionismin Opas, $3^{\text {rd }}$ printing. Virginia, Minn.: Quick Print, no date.

Industrial Workers of the World to IWW-members Email List. "Personal Digital

Communication: IWW Phone/Fax Blitz in Support of FW Budlakoti," September 28,2014

Johnston, W.H. to Oliver Iron Mining Company. "Business Correspondence," March 25, 1912. James S. Steel Papers, Minnesota Historical Society, St. Paul, Minnesota, Box 1.

. "Business Correspondence," March 19, 1912. James S. Steel Papers, Minnesota Historical Society, St. Paul, Minnesota, Box 1.

Kean, Dr. N.D. to Dr. W.H. Magie. "Medical Correspondence, Canisteo Mine, 19081918.” James S. Steel Collection, Minnesota Historical Society, St. Paul, Minnesota, Box 2, Folder 6.

Mantel, Joseph to W.H. Johnston. "Personal Correspondence," March 18, 1912. James S. Steel Papers, Minnesota Historical Society, Box 1. 
Marx, Karl. A Contribution to the Critique of Political Economy. Accessed at Marxists.org, http://www.marxists.org/archive/marx/works/1859/critique-poleconomy/, March 16, 2014. . Theses on Feuerbach 1845. Translated by Cyril Smith. Marx-Engels Internet Archive. Accessed at http://www.marxists.org/archive/marx/works/1845/theses/theses.htm, March 16, 2014.

Mitchell, Pentecost to R.R. Trezona. "Business Correspondence,” August 11, 1909. James S. Steel Collection, Minnesota Historical Society, St. Paul, Minnesota, Box 1, Folder 140.

Myllymaki, Victor. "Personal Correspondence." In Bring Warm Clothes: Letters and Photos from Minnesota's Past, compiled Peg Meier. Minneapolis, Minn.: Star and Tribune Company, 1981.

Nelson-Walkama, Daisy. “Oral history interview,” July 20, 2006. Conducted by Gary Kaunonen. Finnish American Historical Archive, Hancock, Michigan.

Oliver Iron Mining Company to W.J. Trescott. "Business Correspondence, Canisteo Mine, 1908-1918.” James S. Steel Collection, Minnesota Historical Society, St. Paul, Minnesota, Box 2, Folder 6. . "Business Correspondences." Correspondence and Miscellaneous Papers, 190129, Oliver Iron Mining Company Records, Minnesota Historical Society, St. Paul, Minnesota, Box 1, Folder "Community Morals, 1907-10, 1925."

Oppenheimer, Moses. "Direct Action and Sabotage." In The New Review, Vol. 1, No. 4, New York, 1913. 
Orwell, George. 1984. New York: Signet Classic, 1950.

Penguilly, John to T.F. Cole. "Materials Relating to the Oliver Iron Mining Company," January 20, 1903. Minnesota Historical Society Archives, St. Paul, Minnesota. Phillips, U. Utah. "Unless You are Free.” On Fellow Workers, New York: Righteous Babe Records, 1999.

Ponikvard, Veda. "Oral History: Minnesota Radicalism Project." Interview conducted by Carl Ross. Minnesota Historical Society, St. Paul, Minnesota, May 13, 1988.

Pouget, Emile. Sabotage. Translated from the French with introduction by Arturo Giovannitti. Chicago: Charles H. Kerr and Company, 1913.

Power, Victor L. “Personal Journal Entries.” Victor L. Power Papers, Minnesota Historical Society, St. Paul, Minnesota, Box 1. . "Scrapbook: Newspaper Clippings," Vol. 1. Victor L. Power Papers, Minnesota Historical Society, St. Paul, Minnesota, Box 1. . "Standard Diary, 1916" Vol. 2. Victor L. Power Papers, Minnesota Historical Society, St. Paul, Minnesota, Box 1.

Power, Victor L. to J.A.O. Preus. “Government Correspondence,” August 1, 1915. Victor L. Power Papers, Minnesota Historical Society, St. Paul, Minnesota, Box 1. Rein, Wm. Nuoriso, Oppi ja Tyo (Youth, Learning and Labor). .Duluth, Minn.: The Workers' Socialist Publishing Company, 1929.

Satyarthi, Kailash. "Nobel Prize Award Acceptance Lecture.” December 10, 2014, Stockholm, Sweden. Accessed at http://www.nobelprize.org/nobel_prizes/peace/laureates/2014/satyarthilecture_en.html, on December 12, 2014. 
Smith, Walker C. Sabotage: Its History, Philosophy, and Function. Chicago: I.W.W. Publishing Bureau, no date.

State of Minnesota. Department of Labor and Industries. Fifteenth Biennial Report. St. Paul, Minn.: State Printing Office, 1916.

Torma, Fred. "Oral History Interview.” Oral History Collection, Finnish American Historical Archive, Hancock, Michigan.

Trautmann, William E. Why Strikes are Lost \& How to Win. New Castle, Penn..: I.W.W. Publishing Bureau, 1912. Accessed at: http://www.iww.org/history/library/Trautmann/loststrikes.html, May 1, 2014. Superintendent of Eveleth Schools to Thos. F. Cole. "Personal Correspondence," January 30, 1908. Oliver Iron Mining Company Papers, Correspondence and Miscellaneous Papers, 1901-29, Minnesota Historical Society, St. Paul, Minnesota, Box 1, Folder "Community Morals, 1907-10, 1925."

Swanson, Samuel. "Organizing the Steel Workers Union on the Range.” Speech at the Virginia (Minnesota) Teachers’ Institute, September 14, 1968. Samuel Swanson Collection, Minnesota Historical Society, St. Paul, Minnesota. . Sam Swanson Radio Message on Labor Movement in Ely, Minnesota, and Iron Range,” n.d. Samuel Swanson Collection, Minnesota Historical Society, St. Paul, Minnesota, Folder P187.

Thompson, Hunter S. Fear and Loathing in Las Vegas: A Savage Journey to the Heart of The American Dream. Knoph Doubleday Publishing Group, 1971.

Trezona, R.R. to Pentecost Mitchell. “Business Correspondence,” August 11, 1909. 
James S. Steel Collection, Minnesota Historical Society, St. Paul, Minnesota, Box 1, Folder 140.

Unknown songwriter. "The Mysteries of a Hobo's Life." In I.W.W. Songs to Fan the Flames of Discontent, Joe Hill Memorial Edition. Cleveland, Ohio: I.W.W. Publishing Bureau, n.d.

United Steel Workers. "Our History." In Our Union, accessed at, http://www.usw.org/union/history, on December 8, 2014.

Wenzell, Henry Burleigh. Cases Argued and Determined in the Supreme Court of Minnesota, Minnesota Reports Vol. 23. St. Paul, Minn.: Lawyers Co-operative Publishing Co., 1913.

West, George P. “The Mesaba Strike.” In International Socialist Review, Vol. 17. Chicago: Charles H. Kerr Publishing Co., 1916.

\section{Secondary Sources}

Acuña, Rodolfo F. Corridors of Migration: The Odyssey of Mexican Laborers 16001933. Tucson, Ariz.: University of Arizona Press, 2008.

Alanen, Arnold. Morgan Park: Duluth, U.S. Steel, and the Forging of a Company Town. Minneapolis, Minn.: University of Minnesota Press, 2007. . "Considering the Ordinary: Vernacular Landscapes in Small Towns and Rural Areas." In Preserving Cultural Landscapes in America, eds. Arnold R. Alanen and Robert Z. Melnick. Baltimore: The Johns Hopkins University Press, 2000.

Altenbaugh, Richard J. Education for Struggle: The American Labor Colleges of the 1920s and 1930s. Philadelphia: Temple University Press, 1990.

Betten, Neil. "Riot, Revolution, Repression in the Iron Range Strike of 1916." In 360 
Minnesota History, vol. 41, no. 2. Summer 1968.

Brody, David. "The Old Labor History and the New: In Search of an American Working Class." In Labor History, Vol. 20. London: Routledge, 1979.

Brunfelt, Pamela A. "Political Culture in Microcosm: Minnesota's Iron Range." Accessed at www.minnesotahumanities.org/resources/political\%20culture\%20in\%20microcos m.pdf, on November 15, 2014.

Burke, Peter. What is Cultural History?, Second Edition. Malden, Mass.: Polity Books, 2008.

Campbell, J. Peter. "The Cult of Spontaneity: Finnish-Canadian Bushworkers and the Industrial Workers of the World in Northern Ontario, 1919-1934.” In Labour/Le Travail, 41, Spring 1998.

Cohen, Michael. "Cartooning Capitalism: Radical Cartooning and the Making of American Popular Radicalism in the Early Twentieth Century.” In International Review of Social History. Cambridge: Cambridge University Press, 2007.

Cronon, William. Nature's Metropolis: Chicago and the Great West, reprint edition. New York: W.W. Norton \& Co., 1992.

Dardess, George. "Review, Bringing Comic Books to Class.” In College English, Vol. 57, No. 2, National Council of Teachers of English, Feb. 1995.

Deaux, Kay. "Social Identity." Accessed at http://www.utexas.edu/courses/stross/ant393b_files/ARTICLES/identity.pdf, on November 15, 2014.

DeGenaro, William. Who Says?: Working-Class Rhetoric, Class Consciousness, and 361 
Community. Pitt Comp Literacy Culture Series, Pittsburg, Penn.: University of Pittsburg Press, 2007.

Detienne, Marcel and Jean-Pierre Vernant. Cunning Intelligence in Greek Culture and Society. Translated from the French by Janet Lloyd. Chicago: University of Chicago Press, 1991.

Dubofsky, Melvyn. We Shall be All: A History of the IWW, Industrial Workers of the World. New York: New York Times Book Company, 1969.

Eleff, Robert M. "The 1916 Minnesota Miners' Strike against U.S. Steel." In Minnesota History, vol. 51, no. 2. Summer 1988.

Fedo, Michael. The Lynchings in Duluth. St. Paul, Minn.: Minnesota Historical Society Press, 2000.

Feenberg, Andrew. "Democratic Rationalization: Technology, Power, and Freedom." In Philosophy of Technology: The Technological Condition, An Anthology, eds. Robert C. Scharff and Val Dusek. Malden, Mass.: Blackwell Publishing, 2003. . Transforming Technology: A Critical Theory Revisited. Cambridge: Oxford University Press, 2002.

Freire, Paulo. Pedagogy of the Oppressed, $30^{\text {th }}$ Anniversary Edition. Translated by Myra Bergman Ramos. New York: Bloomsbury Academic, 2000.

Gerring, John. "Ideology: A Definitional Analysis.” In Political Research Quarterly, Vol. 50, No. 4, 1997.

Gibney, Alex. Director. Gonzo: The Life and Work of Dr. Hunter S. Thompson. Magnolia Home Entertainment, 2008.

Hannula, Reino. An Album of Finnish Halls: Yesterday and Today. Finn Heritage, 1991. 362 
Haynes, John E. "Revolt of the 'Timber Beasts': IWW Lumber Strike in Minnesota.” In Anne J. Aby ed. The North Star State: A Minnesota History Reader. St. Paul, Minn.: Minnesota Historical Society Press, 2002.

Hoglund, A. William. Finnish Immigrants in America, 1880-1920. Madison, Wisc.: University of Wisconsin Press, 1960.

Hudelson, Richard and Carl Ross. By the Ore Docks: A Working Peoples' History of Duluth. Minneapolis, Minn.: University of Minnesota Press, 2006.

Industrial Workers of the World. "Solidarity Forever." In IWW Cultural Icons. Accessed at http://www.iww.org/history/icons/solidarity_forever, May 1, 2014.

__. "IWW Chronology: 1904-1911." Accessed at www.iww.org, September 2010.

Johnson, Robert R. User-centered Technology: A Rhetorical Theory for Computers and Other Mundane Artifacts, SUNY Series, Studies in Scientific and Technical Communication. New York: State University of New York Press, 1998.

Karni, Michael. "Elizabeth Gurley Flynn and the Mesabi Strike of 1916." In Range History, Vol. 5, No. 4. Chisholm, Minn.: Iron Range Research Center, 1981. . "The Founding of the Finnish Socialist Federation." In For the Common Good: Finnish Immigrants and the Radical Response to Industrial America. Superior, Wisc.: Työmies Society, 1977.

Kaunonen, Gary. Challenge Accepted: A Finnish Immigrant Response to Industrial America on Michigan's Copper Country. East Lansing, Mich.: Michigan State University Press, 2010.

. Finns in Michigan. "Discovering the Peoples of Michigan Series." East Lansing, Mich.: Michigan State University Press, 2009. 
. "Arvo Halberg/Gus Hall: The Making of an American Communist."

Unpublished senior honors thesis. Minnesota State University-Mankato, Spring

Semester 2003.

Kaunonen, Gary and Aaron Goings. Community in Conflict: A Working-class History of the 1913-14 Michigan Copper Strike and Italian Hall Tragedy. East Lansing, Mich.: Michigan State University Press, 2013.

Kessler-Harris, Alice. Out to Work: A History of Wage-earning Women in the United States. New York: Oxford University Press, 1982.

Kim, Young Yun. "Ideology, Identity, and Intercultural Communication: An Analysis of Differing Academic Conceptions of Cultural Identity." In Journal of Intercultural Communication Research, 36, 3, 2007.

Kivisto, Peter. "The Decline of the Finnish American Left, 1925-1945." In International Migration Review, Volume 17, Issue 1, Spring 1983. Available at http://www.jstor.org, accessed February 13, 2003

Klemencic, Matjaz. "Slovene Settlements in the United States of America." Accessed at http://www.theslovenian.com/articles/klemencic4.htm, October 30, 2014.

Kostianen, Auvo. "The Forging of Finnish-American Communism, 1917-1924: A Study in Ethnic Radicalism.” Turun Yliopiston Julkaisuja,Annales Universitatis Turkuensis. Series editor, Sarja B, Humaniora. Turku, Finland: Turun Yliopisto, 1978.

Lamppa, Marvin. Minnesota's Iron Country: Rich Ore, Rich Lives. Duluth, Minn.: Lake Superior Port Cities, Inc., 2004.

Lankton, Larry. Cradle to Grave: Life, Work, and Death at the Lake Superior Copper 364 
Mines. New York: Oxford University Press, 1991.

Marcuse, Herbert. “The New Forms of Social Control.” In Philosophy of Technology: The Technological Condition, eds. Robert C. Scharff and Val Dusek. Hoboken, New Jersey: Wiley-Blackwell, 2003.

McCloud, Scott. Understanding Comics: The Invisible Art. New York: Harper Paperbacks, 1994.

Minnesota Historical Society. MNOpedia. "The Relocation of Hibbing, 1919-1921.” Accessed at, http://www.mnopedia.org/event/relocation-hibbing-1919-1921, October 14, 2014.

Ollila, Jr., Douglas J. “The Work People's College: Immigrant Education for Adjustment and Solidarity." In For the Common Good: Finnish Immigrants and the Radical Response to Industrial America, edited by Michael Karni. Superior, Wisc.: Työmies Society, 1977.

. "From Socialism to Industrial Unionism." In The Finnish Experience in the Western Great Lakes Region. (Turku, Finland: Institute for Migration, 1975), 159.

Passi, Michael M. "Finnish Immigrants and the Radical Response to Industrial America." In For the Common Good: Finnish Immigrants and the Radical Response to Industrial America. Superior, Wisc.: Työmies Society, 1977.

Pernicone, Nunzio. Carlo Tresca: Portrait of a Rebel. Oakland, Cali.: AK Press, 2010.

Pinola, Rudolf. Labor and Politics on the Iron Range of Northern Minnesota. Unpublished Ph.D. Dissertation. University of Wisconsin, 1957.

Pinta, Saku. "Interview on IWW History.” Conducted by Gary Kaunonen. Thunder Bay, Ontario, Canada, May 1, 2014. 
Roberts, Kate. "Socialist Opera House, Virginia.” In MNOpedia. Accessed at, http://www.mnopedia.org/structure/socialist-opera-house-virginia, on December 1, 2014.

Roe, James A. "Virginia, Minnesota's Socialist Opera: Showplace of Iron Range Radicalism." In Finnish Americana: A Journal of Finnish American History and Culture, Vol. 9. Edited by Michael Karni. New Brighton, Minn.: Finnish Americana, 1992.

Sale, Kirkpatrick. Rebels Against the Future: The Luddites and their War on the Industrial Revolution. Cambridge, Mass.: Perseus Publishing, 1996.

Schlereth, Thomas J. Cultural History and Material Culture: Everyday Life, Landscapes, Museums. Ann Arbor, Mich.: UMI Research Press, 1990. . "Social History Scholarship and Material Culture Research.” In Material Culture: A Research Guide. Lawrence, Kansas: University Press of Kansas, 1985.

Selzer, Jack. "Rhetorical Analysis: Understanding How Texts Persuade Readers.” In What Writing Does and How it Does It: An Introduction to Analyzing Texts and Textual Practices. Editors Charles Bazerman and Paul Pryor. London: Routledge, 2003.

Streeby, Shelley. Radical Sensations: World Movements, Violence, and Visual Culture. Durham, North Carolina: Duke University Press, 2013.

Sturken, Marita and Lisa Cartwright. Practices of Looking: An Introduction to Visual Culture, $2^{\text {nd }}$ ed. New York: Oxford University Press, 2009.

Theado, C. Kendall. "Narrating a Nation: Second Wave Immigration, Literacy, and the 
Framing of the American Identity." In JAC: A Journal of Rhetoric, Culture, and Politics, 33, 1-2, 2013.

Thompson, Fred W. and Patrick Murfin. The I.W.W.: Its First Seventy Years, 1905-1975.

Chicago: Industrial Workers of the World, 1976.

United Nations. "The Universal Declaration of Human Rights." In Human Rights.

Accessed at http://www.un.org/en/rights/, on December 12, 2014.

Van Cleef, Eugene. “The Finn in America.” In Geographical Review, Volume 6, Issue 3,

September 1918. Available at http://www.jstor.org, accessed February 17, 2003.

Winner, Langdon. "Luddism as Epistemology." In Philosophy of Technology: The

Technological Condition, An Anthology, eds. Robert C. Scharff and Val Dusek.

Malden, Mass.: Blackwell Publishing, 2003.

Zinn, Howard and Donald Macedo. Howard Zinn on Democratic Education, $1^{\text {st }}$ ed.

Boulder, Colo.: Paradigm Publishers, 2008.

Zinn, Howard. A People's History of the United States: 1492 to Present. New York:

Harper Perennial Modern Classics, 2005.

\section{Periodical Sources}

Ahjo (Duluth, Minnesota)

Duluth (Minnesota) Herald

Duluth (Minnesota) News-Tribune

Hibbing (Minnesota) News Tribune

Industrialisti (Duluth, Minnesota)

International Socialist Review (Chicago, Illinois)

Mesaba Ore (Hibbing, Minnesota) 
Sosialisti (Duluth, Minnesota)

Star Tribune (Minneapolis)

Strikers' News (Virginia, Minnesota)

Tie Vapauteen (Duluth, Minnesota)

Työmies (Superior, Wisconsin)

Vermilion Iron Journal (Tower, Minnesota)

Virginia (Minnesota) Daily Enterprise

Wage Slave (Hancock, Michigan) 